Florida International University FIU Digital Commons

4-17-2006

\title{
Examining the process of regime change in the North Atlantic Treaty Organization : the divide between rhetoric and reality
}

Barak Carlson

Florida International University

DOI: $10.25148 /$ etd.FI14052576

Follow this and additional works at: https://digitalcommons.fiu.edu/etd

Part of the International Relations Commons

\section{Recommended Citation}

Carlson, Barak, "Examining the process of regime change in the North Atlantic Treaty Organization : the divide between rhetoric and reality" (2006). FIU Electronic Theses and Dissertations. 2047.

https://digitalcommons.fiu.edu/etd/2047 
FLORIDA INTERNATIONAL UNIVERSITY

Miami, Florida

EXAMINING THE PROCESS OF REGIME CHANGE IN THE

NORTH ATLANTIC TREATY ORGANIZATION:

THE DIVIDE BETWEEN RHETORIC AND REALITY

A dissertation submitted in partial fulfillment of the

requirements for the degree of

DOCTOR OF PHILOSOPHY

in

INTERNATIONAL RELATIONS

by

Barak Carlson

2006 
To: Interim Dean Mark D. Szuchman

College of Arts and Sciences

This dissertation, written by Barak Carlson, and entitled Examining the Process of Regime Change in the North Atlantic Treaty Organization: The Divide between Rhetoric and Reality, having been approved in respect to style and intellectual content, is referred to you for judgment.

We have read this dissertation and recommend that it be approved.

Elisabeth Prugl

Mohaiddin Mesbahi

Richard S. Olson

Ralph S. Clem, Major Professor

Date of Defense: April 17, 2006

The dissertation of Barak Carlson is approved.

Interim Dean Mark D. Szuchman

College of Arts and Sciences

Interim Dean Stephan L. Mintz

University Graduate School

Florida International University, 2006 


\section{ACKNOWLEDGMENTS}

My interest in international regimes, including the role of the North Atlantic Treaty

Organization, was initially piqued during my participation in a number of NATO Steering

Groups while I was assigned as a project officer to the U.S. Department of Defense Joint Program Office for Unmanned Aerial Vehicles during the late 1990s. My experience with various NATO committees gave me an appreciation for the wide range of issues undergoing continuous scrutiny and coordination among Alliance member governments. Subsequent exchanges with my peers during numerous visits to Allied military installations gave me a greater appreciation for the unique role of the United States within NATO and the emerging differences in worldviews and capabilities among Alliance members. I later drew upon these experiences as an instructor at the Air Command and Staff College, where I was fortunate to be surrounded by top-notch academicians who offered further insights into the changing nature of the Alliance and of contemporary diplomacy in general.

The writing of this dissertation has been among the most challenging and humbling experiences of my life and could not have been completed without the guidance and support of many people. I wish to thank the faculty and staff of the International Relations Department at Florida International University for their inspiration and support throughout my studies. This department is made up of excellent scholars who present a valuable and diverse curriculum while demonstrating a genuine interest in the success of their students. My committee was made up of exemplary professors from both the International Relations and Political Science departments that were not only able to provide me with valuable scholarly input, but also offered a consistent level of encouragement that exceeded my expectations. I would like recognize my major professor, Dr. Ralph Clem, for his ability to 
help me navigate through the many challenges presented by this research while retaining a positive outlook. The other members of my committee, Dr. Elisabeth Prugl, Dr. Mohiaddin Mesbahi, and Dr. Richard Olson, were each extraordinarily helpful in guiding my research and offering constructive feedback throughout the writing process. Finally, I would like to thank my wife, Christine, for her patient review of innumerable drafts and for all she continues to do to make me cherish her more each day. 


\section{ABSTRACT OF THE DISSERTATION \\ EXAMINING THE PROCESS OF REGIME CHANGE IN THE \\ NORTH ATLANTIC TREATY ORGANIZATION: \\ THE DIVIDE BETWEEN RHETORIC AND REALITY \\ by \\ Barak Carlson \\ Florida International University, 2006 \\ Miami, Florida \\ Professor Ralph S. Clem, Major Professor}

The North Atlantic Treaty Organization (NATO) is a product of the Cold War through which its members organized their military forces for the purpose of collective defense against the common threat of Soviet-backed aggression. Employing the terminology of regime theory, the creation of NATO can be viewed as the introduction of an international security regime. Throughout the Cold War, NATO member states preserved their commitment to mutual defense while increasingly engaging in activities aimed at overcoming the division of Europe and promoting regional stability. The end of the Cold War has served as the catalyst for a new period of regime change as the Alliance introduced elements of a collective security regime by expanding its mandate to address new security challenges and reorganizing both its political and military organizational structures.

This research involves an interpretive analysis of NATO's evolution applying ideal theoretical constructs associated with distinct approaches to regime analysis. The process of regime change is investigated over several periods throughout the history of the Alliance 
in an effort to understand the Alliance's changing commitment to collective security. This research involves a review of regime theory literature, consisting of an examination of primary source documentation, including official documents and treaties, as well as a review of numerous secondary sources. This review is organized around a typology of power-based, organization-based, and norm-based approaches to regime analysis. This dissertation argues that the process of regime change within NATO is best understood by examining factors associated with multiple theoretical constructs. Relevant factors provide insights into the practice of collective security among NATO member states within Europe, while accounting for the inability of the NATO allies to build on the experience gained within Europe to play a more central role in operations outside of this region. This research contributes to a greater understanding of the nature of international regimes and the process of regime change, while offering recommendations aimed at increasing NATO's viability as a source of greater security and more meaningful international cooperation. 


\section{TABLE OF CONTENTS}

I. OVERVIEW OF RESEARCH AND LITERATURE REVIEW ...................... 1

General Statement of Problem Area .......................................................... 1

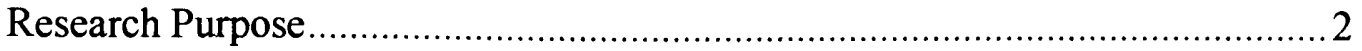

Significance of Study ................................................................. 4

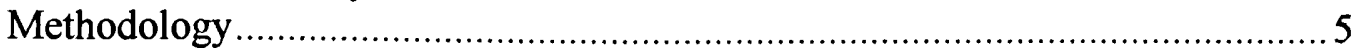

Theoretical Perspective and Literature Review........................................... 8

Realism and Power-based Regime Analysis .................................................. 14

Neoliberal Institutionalism and Organization-based Regime Analysis..............29

Liberalism, Constructivism and Norm-based Regime Analysis..........................39

Distinguishing Collective Security and Collective Defense Regimes.................51

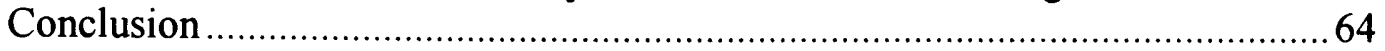

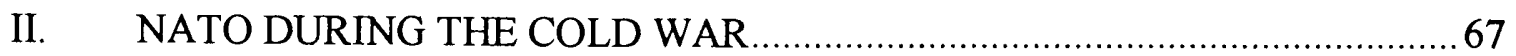

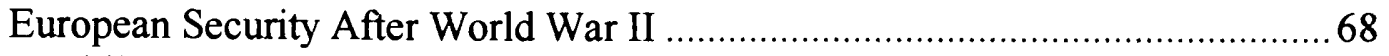

Establishing the North Atlantic Treaty ............................................................ 76

Acceptance of West German Statehood and NATO Membership ....................82

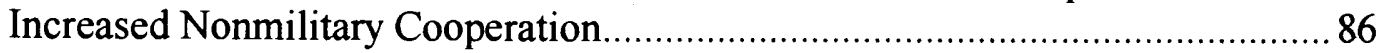

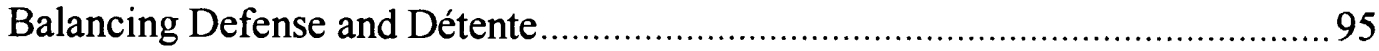

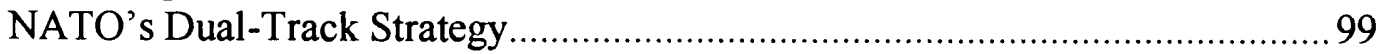

European Integration During the Cold War.................................................... 101

Regime Analysis: NATO During the Cold War............................................... 104

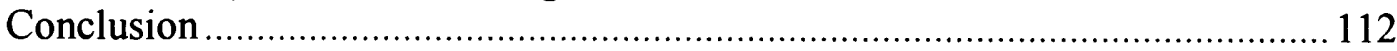

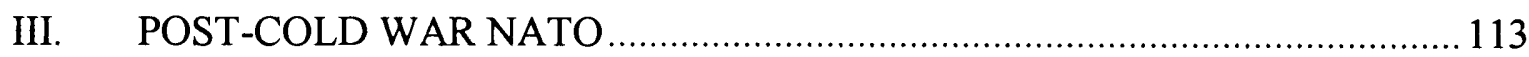

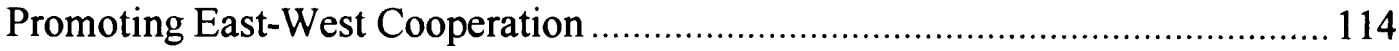

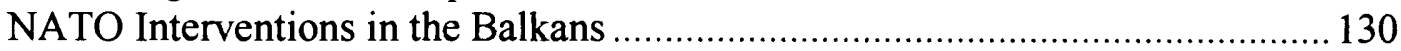

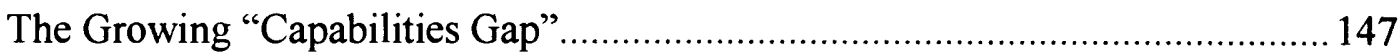

The European Union as a Rival Security Regime ........................................... 157

Regime Analysis: Post Cold War NATO ……................................................. 168

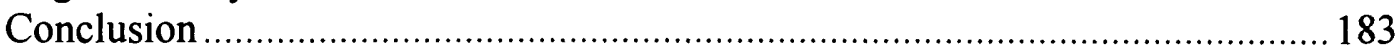

IV. NATO'S ROLE IN THE GLOBAL WAR ON TERRORISM .......................... 186

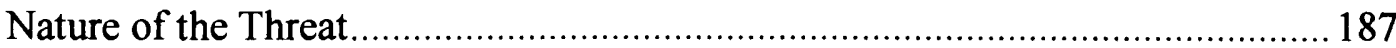

Initial Responses to the September 2001 Attacks on the United States .............. 196

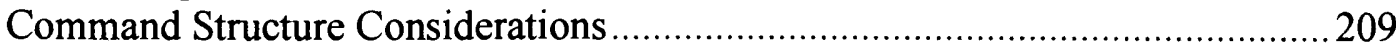

NATO Support for Operation Enduring Freedom ...........................................2 219

NATO's Role in Stabilization and Reconstruction Operations in Afghanistan ...228

Confronting Iraq Over Alleged WMD Development ....................................223

NATO Support for Operation Iraqi Freedom ...................................................24 249

NATO's Role in Stabilization and Reconstruction Operations in Iraq ...............254

Contrasting Stabilization and Reconstruction Operations ..................................260 
Regime Analysis: NATO's Role in the Global War on Terrorism

Conclusion

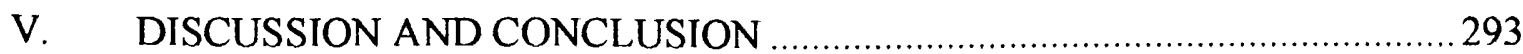

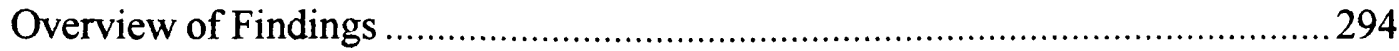

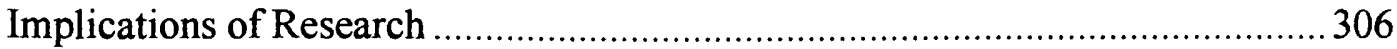

Recommendations for Further Research ........................................................ 324

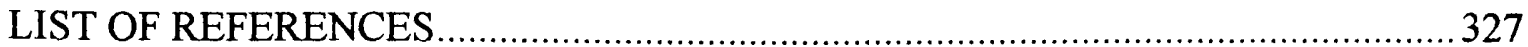

VITA

356 
LIST OF ACRONYMS

$\mathrm{ABM}$

ACO

ANO

AFNORTH

AFSOUTH

ANA

AWACS

BMD

CFE

CFSP

CINCSOUTH

COMAIRSOUTH

COMNAVSOUTH

COMSTRIKFORSOUTH

CJTF

CPA

CSBM

CSCE

DCI

DPC

EAPC

EC
Anti-Ballistic Missile

Allied Command Operations

Abu Nidal Organization

Allied Forces North

Allied Force South

Afghan National Army

Airborne Warning and Control System

Ballistic Missile Defense

Conventional Forces Europe

Common Foreign and Security Policy

Commander-in-Chief, Allied Forces Southern Europe

Commander Allied Air Forces Southern Europe

Commander Allied Naval Forces Southern Europe

Commander Striking and Support Forces Southern Europe

Combined Joint Task Force

Coalition Provisional Authority

Confidence and Security-Building Measures

Council on Security and Cooperation in Europe

Defense Capabilities Initiative

Defense Planning Committee

Euro-Atlantic Partnership Council

European Community 
ECSC

EDC

EEC

EPAF

ERRF

ESDI

EU

EUCOM

EURATOM

FLA

FRELOC

FYROM

GDP

GWOT

IAEA

ICC

IFOR

IMF

INF

ISAF

JFC

JNA

KFOR
European Coal and Steel Community

European Defense Community

European Economic Community

European Participating Air Forces

European Rapid Reaction Force

European Security and Defense Identity

European Union

United States European Command

European Atomic Energy Community

Future Large Aircraft

Fast Relocation

Former Yugoslav Republic of Macedonia

Gross Domestic Product

Global War on Terrorism

International Atomic Energy Agency

International Criminal Court

Implementation Force

International Monetary Fund

Intermediate Nuclear Forces

International Security Assistance Force

Joint Force Command

Yugoslavian Peoples Army

Kosovo Force 
KLA

MAD

MLF

MLRS

NAC

NACC

NAEWF

NATO

NBC

NIWS

NORAD

NPT

NRF

NTECG

OAF

ODF

OEF

OSCE

PCC

PfP

PLF

PLO

PRT
Kosovo Liberation Army

Mutually Assured Destruction

Multi-Lateral Force

Multiple Launch Rocket System

North Atlantic Council

North Atlantic Cooperation Council

NATO Airborne Early Warning Force

North Atlantic Treaty Organization

Nuclear, Biological, and Chemical

NATO Intelligence Warning System

North American Air Defense Command

Treaty on the Non-Proliferation of Nuclear Weapons

NATO Reaction Force

NATO Training and Equipment Coordination Group

Operation Allied Force

Operation Deliberate Force

Operation Enduring Freedom

Organization for Security and Cooperation in Europe

Prague Capabilities Commitment

Partnership for Peace

Palestine Liberation Front

Palestine Liberation Organization

Provincial Reconstruction Team 
ROE

SACEUR

SACLANT

SALT

SEAD

SFIR

SFOR

SHAPE

SOF

STANAVFORLANT

STANAVFORMED

TEDC

UN

UNAMA

UNAMI

UNMOVIC

UNPA

UNSCOM

UNSCR

USAFE

USCENTCOM

WEU
Rules of Engagement

Supreme Allied Commander Europe

Supreme Allied Commander Atlantic

Strategic Arms Limitations Talks

Suppression of Enemy Air Defenses

Stabilization Force (Iraq)

Stabilization Force (Kosovo)

Supreme Headquarters Allied Powers Europe

Special Operations Forces

Standing Naval Forces Atlantic

Standing Naval Forces Mediterranean

Training and Education Doctrine Center

United Nations

United Nations Assistance Mission in Afghanistan

United Nations Assistance Mission in Iraq

United Nations Monitoring, Verification, and Inspection Commission

United Nations Protected Areas

United Nations Special Commission

United Nations Security Council Resolution

United States Air Forces Europe

United States Central Command

Western European Union 
It is generally recognized as undesirable that an international organization should be frozen into a rigid pattern.

- Lord Hastings Ismay, Secretary General of NATO (1955)

Chapter 1: Overview of Research and Literature Review

\section{General Statement of Problem Area}

The North Atlantic Treaty Organization (NATO) is a product of the Cold War through which its members organized their military forces for the purpose of collective defense against the common threat of Soviet-backed aggression. Employing the terminology of regime theory, the creation of NATO can be viewed as the introduction of an international security regime. In addition to this initial mutual defense obligation, the member states of NATO increasingly engaged in activities aimed at overcoming the division of Europe and promoting regional stability that foreshadowed the introduction of a collective security regime. During the more than forty years between the formation of the Alliance and the dissolution of the Soviet Union, NATO member states jointly addressed such issues as West German statehood and Alliance membership, increased nonmilitary cooperation, and the pursuit of détente between East and West. Each of these issues presented numerous challenges and introduced tensions among member states that threatened to undermine Alliance unity.

The end of the Cold War has served as the catalyst for a new period of regime change within NATO to cope with a new security environment. NATO has expanded its mandate to address new security challenges and reorganized both its political and military organizational structures. As NATO Secretary General Javier Solana, observed in the late 1990s, "Over the years, NATO has helped develop principles of collective security - 
and the instruments necessary to sustain it - for the wider Euro-Atlantic region. Although one of NATO's core functions remains collective defense, the end of the Cold War offered opportunities for allies to pursue a much broader, cooperative approach to security." This dissertation assesses various ways that international relations theory accounts for the changes in the Alliance's post-Cold War approach to security by reviewing NATO's evolution both during and after the Cold War and the resulting willingness of Alliance members to respond collectively to global threats.

\section{Research Purpose}

Literature in the field of international relations recognizes collective defense as a security arrangement where states pledge their cooperation and support in the event that any alliance member is attacked by a third party. Collective defense arrangements generally emphasize military coordination and are organized in response to a specified threat. In contrast, collective security arrangements generally seek to address a broad range of threats originating from either within or outside of the alliance. Collective security arrangements commonly obligate members to act in response to any perceived threat to international peace, including emerging threats not anticipated during the formation of the agreement.

Numerous scholars and political leaders have portrayed NATO as undergoing a regime change from an organization committed to the practice of collective defense to one aspiring to collective security. NATO's expansion into Eastern Europe and its leadership of peacekeeping operations in the Balkans are commonly cited as examples of

\footnotetext{
${ }^{1}$ NATO Office of Information and Press, "Collective Security and the Post-Cold War World: Speech by Secretary Solana at the Conference on Crisis Management and NATO Reform, June 1998," http://www.nato.int/docu/speech/1998/s980615a.htm.
} 
the member governments' efforts to reinvent NATO as a collective security organization. Yost provides an informative look at this "transformation" and expresses a number of reservations regarding the implications of regime change. ${ }^{2}$ Kupchan and Kupchan view this transformation in more positive terms, characterizing NATO as moving beyond its role as a traditional alliance and functioning as a hybrid between a collective defense and a collective security organization. ${ }^{3}$ While these and other works acknowledge the Alliance's collective security aspirations, there has been little effort to systematically explore the resulting pattern of cooperation resulting from this alleged regime change. Subsequent efforts to expand the practice of collective security to threats emerging outside of Europe's borders have been marked by divisions among Alliance members and a marginalized role for the Alliance. This research seeks to identify theoretical constructs that contribute to an understanding of the Alliance's foray into the practice of collective security.

This research seeks to answer the questions, "What factors have influenced NATO's introduction of a collective security regime?" and "Why have Alliance members encountered difficulties extending NATO's mandate to include the practice of collective security outside of Europe?" This study utilizes existing scholarship on international regimes to examine both internal and external factors that are likely to have influenced the decisions of NATO member states to act collectively in response to shared security challenges. This dissertation provides insights into the behavior of Alliance members

${ }^{2}$ David Yost, NATO Transformed - The Alliance's New Roles in International Security (Washington D.C.: United States Institute of Peace Press, 1998).

${ }^{3}$ Charles Kupchan and Clifford Kupchan, "Concerts, Collective Security, and the Future of Europe," International Security 16. no 1 (1991): 114-161. 
both during and after the Cold War and complements other research assessing contemporary patterns of international cooperation and conflict.

\section{Significance of Study}

This dissertation contributes to existing scholarship on the relationship between international regimes and state behavior. ${ }^{4}$ While scholars commonly examine the conditions favoring regime formation and compliance, comparatively little research has been completed regarding the sources of change in existing international regimes. NATO's contributions to transatlantic security during the Cold War are well-documented and there is generally little controversy regarding the Alliance's ability to maintain a credible commitment to collective defense against Soviet-backed aggression throughout this era. ${ }^{5}$ NATO's contribution to transatlantic security in the post-Cold War era has been the subject of less study and its contributions to transatlantic security remain much more contentious. Much of the existing literature on changes to transatlantic security regimes focuses on the implications of organizational changes within the Alliance rather than the conditions leading to these reforms. ${ }^{6}$ A closer look at the behavior of Alliance members toward the demands of regime change reveals a complex and inconsistent pattern of cooperation. This research investigates the process of regime change while

\footnotetext{
${ }^{4}$ Relevant scholarship includes Stephen Krasner, ed. International Regimes (Ithaca, NY: Cornell University, 1983), Joseph Nye, "Nuclear Learning and U.S.-Soviet Security Regimes," International Organization 41 (1987), and Oran Young, Compliance and Public Authority: A Theory with International Applications (Baltimore, MD: Johns Hopkins Press, 1979).

${ }^{5}$ Relevant scholarship includes Alistair Buchan, NATO in the 1960s (London: Wiedenfeld and Nicolson, 1960) and John Lewis Gaddis, We Now Know: Rethinking Cold War History (New York: Oxford University Press, 1990).

${ }^{6}$ An example of an emphasis on organizational implications can be found in Robert McCalla. "NATO's Persistence After the Cold War," International Organization 50, no 3 (Summer 1996): 445-475.
} 
drawing upon divergent approaches to regime analysis as they relate to NATO's continued evolution since the end of the Cold War.

\section{Methodology}

This research involves an interpretive analysis of NATO's evolution applying ideal theoretical constructs associated with distinct approaches to regime analysis. This is an informal, qualitative methodology that aims at gaining a greater understanding of the events in question. The process of regime change is investigated over several periods throughout the history of the Alliance in an effort to understand the Alliance's changing commitment to collective security. This research involves the examination of primary source documentation, including official documents and treaties, as well as a review of numerous secondary sources. The approach to this research accepts the likelihood that there are several complementary factors influencing the practice of collective security among NATO member states. Potential explanations are drawn from a review of regime theory literature, which are organized around a typology of power-based, organizationbased, and norm-based approaches to regime analysis. Various factors associated with each approach to regime analysis are examined throughout a discussion of NATO's evolution across three time periods.

The first period of study involves an examination of the factors contributing to NATO's creation and evolution during the Cold War. NATO was organized in response to a unique set of challenges facing the United States and Europe in the late 1940s. The North Atlantic Treaty embodied an unprecedented peacetime security regime obliging member states to equate an attack on any member state to an attack on themselves. The acceptance of this collective defense commitment served as the foundation for 
international cooperation and encouraged the formation of more extensive ties among NATO member states. Both Alliance procedures and organizations evolved over subsequent decades in response to internal and external pressures. These changes were generally intended to increase the security of Alliance members while maintaining unity within the Alliance. Throughout this period, NATO member states remained committed to a collective defense regime while introducing reforms that enabled the Alliance to pursue objectives commonly associated with the practice of collective security.

The second period of study emphasizes NATO's adoption of a collective security regime in the immediate post-Cold War era. The process of regime change accelerated after the end of the Cold War as the Alliance found ways to become more active in a more permissive security environment. Member states viewed NATO as a means of contributing to transatlantic security by serving as a stabilizing force at a time of increased uncertainty regarding the future of European security affairs. Despite expectations that the dissolution of the Soviet Union would lead to the United States' abandonment of Europe, American leaders chose to remain engaged in Europe and initiated reforms that would retain NATO's central role in preserving peace throughout the region. The practice of collective security was also promoted by organizational and normative factors that increased the scope of activities undertaken under the purview of NATO leaders. The changes introduced during this period encouraged an increased dialogue within the Alliance and greater engagement with neighboring states. These activities soon led to the expansion of the Alliance to include more of Central and Eastern Europe and the conduct of combined military interventions to address emerging security challenges within the region. 
The third period of study examines NATO's role in the Global War on Terrorism (GWOT) following the attacks by Al Qaeda on the United States in September 2001. NATO member states initially demonstrated their solidarity with the United States by immediately invoking the mutual defense clause specified in Article Five of the North Atlantic Treaty for the first time in the history of the Alliance. However, while formulating a response to the attacks, the United States rejected the option of deferring to NATO for leadership of the military offensive in favor it leading an ad-hoc coalition. While numerous NATO member states participated in Operation Enduring Freedom (OEF) through bilateral agreements with the United States, the Alliance's formal authority was limited to directing supporting missions until the North Atlantic Council (NAC) eventually assumed leadership of the International Security Assistance Force (ISAF) conducting peacekeeping operations in Afghanistan. Even while military operations were underway in Afghanistan, accusations that the Iraqi government had ties to terrorist organizations and continued to possess weapons of mass destruction (WMD) alarmed many members of the Alliance. NATO member states were unable to achieve a consensus regarding the nature of the Iraqi threat and the NAC refused to act on American requests to provide assistance with war preparations. The lack of consensus within the Alliance meant that NATO was neither a source of assistance to the Americanled coalition, nor was it able to dissuade the United States and a handful of allies from invading Iraq. Despite the creation of an international security force similar to ISAF, the Alliance avoided a significant role in the Iraqi stabilization and reconstruction effort beyond an agreement to provide training and technical assistance. 
This dissertation argues that the process of regime change within NATO is accounted for by various factors associated with power-based, organization-based and norm-based approaches to regime analysis. Relevant factors associated with each of these theoretical constructs are identified through an examination of international relations literature related to regime theory. These factors are employed in subsequent chapters to demonstrate the applicability of these theoretical constructs to the behavior of NATO member states within the Alliance. These approaches each provide insights into the practice of collective security among NATO member states within Europe, while accounting for the inability of the NATO allies to build on the experience gained within Europe to play a more central role in operations outside of this region.

\section{Theoretical Perspective and Literature Review}

Regime theory has remained an active subfield in international relations since its origin in the work of scholars studying transnationalism in the early 1970s. The literature addresses the nature of regimes as well as questions of how and why regimes form and the ways regime compliance is enforced. Scholars in this field seek to understand why regimes are established to govern some aspects of international cooperation rather than others.

The first question likely to be asked by a student of regime theory is "What are international regimes?" It is clear that regimes promote cooperation among states as an alternative to relying on self-help strategies to manage conflicts and interdependence problems, but there are a surprising number of definitions of the term. Many definitions of regimes emphasize their organizational characteristics. Keohane defines international regimes as "institutions with explicit rules, agreed upon by governments, that pertain to 
particular sets of issues in international relations." 7 These rules and procedures regulate the conduct of states in a specified issue area and tend to associate regimes with international law.

A normative component is also common among definitions offered in the literature. Regimes specify the range of acceptable behavior to be encouraged or tolerated among participants. Young emphasizes this aspect of regimes in his definition, stating, "International regimes are human artifacts characterized by a conjunction of behavioral regularities and convergent expectations on the part of their members.", Other scholars conceive of international regimes as "social institutions which regulate conflicts between states by constraining their behavior through the observation of norms and rules in their dealing with disputed objects." ${ }^{9}$

An element of effectiveness is also important to the definition of regimes. A discussion of regimes should have some means of distinguishing empty political rhetoric from successful efforts to instill international order. For example, the Kellogg-Briand Pact of 1927, condemning "recourse to war for the solution of international controversies" should be viewed as a weak (or even failed) regime because it was not accompanied by behavioral changes on the part of signatory states. Keohane argues against the measure of effectiveness, finding it sufficient that a regime's rules are taken

\footnotetext{
${ }^{7}$ Robert Keohane, International Institutions and State Power: Essays in International Relations Theory (Boulder, CO:Westview Press, 1989), 3.

${ }^{8}$ Owen Young, Compliance and Public Authority: A Theory with International Applications (Baltimore, MD: Johns Hopkins Press, 1989), 109.

${ }^{9}$ Manfred Efinger, Volker Rittberger, and Michael Zürn, International Regimes in East-West Relations (London: Pinter Press, 1988), 69.
} 
into account by participants, rather than complied with. He states, "A set of rules need not be 'effective' to qualify as a regime, but it must be recognized as continuing to exist. Using this definition, regimes can be identified by the existence of explicit rules that are referred to in an affirmative manner by governments, even if they are not necessarily scrupulously observed." 10 This assertion is also made by Haggard and Simmons who point out that to define regimes on the basis of observed behavior, and then use them to explain the same behavior is a form of circular reasoning and is logically unsound. ${ }^{11}$

Some scholars remain dissatisfied with the terminology altogether. Stein observes that "scholars have fallen into using the term 'regime' so disparately and with such little precision that it ranges from an umbrella for all international relations to little more than a synonym for international organizations." 12 As a structural realist, Strange finds the concept to be "fuzzy" and less useful for understanding international relations than "fundamental" concepts such as power and interest. She offers an alternative definition of regimes as "the government of a society by an individual, a dynasty, party or group that wields effective power over the rest of society." 13 She concludes that scholars are better off studying underlying power structures than regimes, which are merely symptoms of these structures.

\footnotetext{
${ }^{10}$ Robert Keohane, "Institutional Theory and the Realist Challenge After the Cold War,"in Neorealism and Neoliberalism: The Contemporary Debate, ed. David Baldwin (New York: Columbia University Press, 1989), 28.

"Stephen Haggard and Beth Simmons. "Theories of International Regimes," International Organization 41, no 3 (Summer 1987): 492-493.

${ }^{12}$ Arthur Stein, "Coordination and Collaboration: Regimes in an Anarchic World," International Organization 36, no 2 (Spring 1982): 299.

${ }^{13}$ Susan Strange, "Cave! Hic Dragones: A Critique of Regime Analysis," in International Regimes, ed. Stephen Krasner (Ithaca, NY: Cornell University, 1993), 344.
} 
One commonly cited definition combines many of the elements of other

definitions, while withholding judgment regarding the factors bringing the regime into existence. Krasner defines international regimes as "implicit or explicit principles, norms, rules, and decision-making procedures around which actors' expectations converge in a given area of international relations." ${ }^{14}$ Insights into the constitutive elements of this definition are provided by Haufler who observes, "Principles are beliefs of fact, cause, and right. Norms are standards of behavior. Rules tell the actors what to do or not to do under specified conditions. Decision-making procedures refer to practice and implementation." ${ }^{\prime 5}$ This study utilizes Krasner's definition of international regimes along with an understanding of the constitutive elements as specified by Haufler above.

Various approaches to regime analysis place different degrees of emphasis on the collective will of member states rather than the characteristics of the organizations created to carry out this will. As a means of retaining this distinction, this study uses the term "international regime" when discussing the scope of collective agreements including principles, norms, and shared objectives. The term "international organization" is used when discussing the bodies that pursue the collective will of regime participants. It is important to keep these two components distinct when investigating the behavior of states towards regimes, particularly in discussions regarding an insufficiency of common will, rather than an inability to carry out the common will.

\footnotetext{
${ }^{14}$ Stephen Krasner, ed. International Regimes (Ithaca, NY: Cornell University Press, 1983), 2.

${ }^{15}$ Virginia Haufler, "Crossing the Boundary between Public and Private: International Regimes and NonState Actors," in Regime Theory and International Relations, ed. Volker Rittenbeger, (Oxford: Clarendon Press, 1993), 96-7.
} 
The increased scope of international regimes since 1945 is reflected in the growth of formally chartered international organizations from fewer than 100 in 1945 to nearly 200 by 1960 and to over 600 by $1980 .^{16}$ Following this period, the growth in the number of international organizations has accelerated since the end of the Cold War.

International regimes exist in many issue areas where states and other international actors have a desire to take collective action. Examples of regimes include the GATT-based international trade regime, the nuclear non-proliferation regime, and the regime for the protection of the ozone layer. Environmental regimes are abundant, addressing such issues as air pollution across state borders and fishing in international waters. Many aspects of the global economy are subject to regimes. The World Trade Organization (WTO) oversees international trade regimes. Monetary policies are highly institutionalized through the International Monetary Fund (IMF). In addition to these issue areas, regimes also play an important role in international security. Numerous international security regimes have been examined in the literature on International Relations and these security regimes have been found to have both global and regional consequences.

The Tübingen project is an informative study on international security regimes in the context of East-West relations in Europe. ${ }^{17}$ The case studies were selected to test the effectiveness of regimes by examining regime compliance when overall relations among the participants are in a period of decline. The researchers declared a regime to be

\footnotetext{
${ }^{16}$ Harold Jacobson, Networks of Interdependence: International Organizations and the Global Political System (New York: Alfred Knopf Press, 1984), 100-2.

${ }^{17}$ Manfred Efinger, Volker Rittberger, and Michael Zürn, International Regimes in East-West Relations (London: Pinter Press, 1988).
} 
present in a given issue area if two conditions were met: (1) the actors in the issue area (de facto states) had agreed upon a set of principles, norms, rules, and procedures to govern their behavior with respect to the conflict(s) in question, and (2) the rules thereby created had proved effective in the sense that they were, by and large, complied with by the actors. Efinger, Rittberger, and Zürn carried out case studies in thirteen issue areas. By these standards, several regimes historically affecting transatlantic security are judged to be effective, including an intra-German trade regime introduced in the $1960 \mathrm{~s}$, a regime for access to West Berlin in the mid-1970s, and the creation of the Confidence and Security-Building Measures (CSBM) regime set up in the mid-1980s.

While new regimes are continuously being debated and formalized, existing regimes also evolve and change over time. Birnie examines the evolution of regimes in her study of international treaties and conventions. ${ }^{18}$ She views treaties as the first step in regime formation, where general principles are agreed to and serve as a foundation for negotiations for more detailed and demanding agreements. Regimes begin as a framework and adapt to changes in the security environment, rather than representing a static set of rules. Each state may pursue regime change in a number of ways such as introducing a regime that better suits its interests or withdraw from existing regimes. While a comprehensive theory of regime change has yet to emerge, scholars and practitioners of international negotiations have offered a wide range of explanations for success or failure in efforts to reach agreement on rules, norms, and decision-making procedures to deal with common problems.

\footnotetext{
${ }^{18}$ Patricia Birnie, "The Scope, Limits, and Theoretical Basis of International Legal Regulation," in The International Politics of the Environment, eds. Andrew Hurrell and Benedict Kingsbury (New York, Oxford University Press, 1992), 51-84.
} 
Huntington identifies three related factors contributing to the creation of a collective defense regime overseen by NATO. ${ }^{19}$ The first of these are shared economic interests. The second is shared political and economic values, based on a common commitment to liberal democracy and capitalism. The third is the shared perception of a threat to the existing balance of power emerging from the Soviet Union. The importance of each of these factors is emphasized in competing approaches to regime analysis that align themselves quite well with general theoretical perspectives in international relations. He finds the balance of power factor to be the most significant, stating "Without the last of these three, the [regime] would never have come into existence."20 The factors Huntington identifies as influencing the creation and maintenance of international regimes are similar to others proposed throughout the literature. The remainder of this chapter reviews the literature on the theoretical perspectives associated with power-based, organization-based, and norm-based approaches to regime analysis. My typology of regime approaches distills several factors related to each of the theoretical constructs that are later utilized to examine the process of regime change throughout the history of the NATO Alliance.

\section{Realism and Power-based regime analysis}

Realism is a state-centered view of the international system that strives to be nonnormative, describing relations between states as they are rather than how they should be. Realists view states as the principal actors in world politics, focusing primarily on the

\footnotetext{
${ }^{19}$ Samuel Huntington, "Why International Primacy Matters." International Security 17 no. 4 (Spring 1993): 68-83.

${ }^{20}$ Ibid, 71.
} 
most powerful states, because these states dominate and shape international politics. This body of theory was in many ways formed in reaction to the idealism of the early twentieth century, and the failure of liberalism to reorganize the international environment in a way that would lead to a more peaceful world. Realists continue to view the international system as a Hobbesian state of nature. While they may agree that creating a peaceful world would be desirable, they recognize that competition and conflict are fundamental aspects of international relations.

In this environment, realists characterize relations between states as conflict and competition as states seek to preserve their interests against the competing interests of other states. Realists depict international cooperation as extremely difficult to achieve, because of each state's preoccupation with security. States recognize that there are potential gains from cooperation, but they must remain conscious of relative gains. Realists argue that states are usually more concerned about relative gains than absolute gains, and are interested in how much a cooperative partner gains from any interaction. Power-based regime analysis is favored by realists and neo-realists who tend to view regimes as compromises in self-interest.

These theorists generally characterize the formation of international regimes as a means of promoting the interests of particular member states. Regime creation and regime change can be viewed as functions of the existing distribution of power.

Goldstein represents the views of many realists with his emphasis on the extent to which contemporary international regimes reflect the interests of dominant states at the time of 
their founding. ${ }^{21}$ The nature of contemporary international regimes is thought to be explained in large part by the balance of power and the preferences of the most powerful states in the international system. In this way, international regimes are simply "a record of the methods and results of power politics."22 Several theorists have contributed important ideas to the development of a realist perspective on international regimes.

Hans Morgenthau is considered by many to be the "father" of modern realism. For Morgenthau, politics is reduced to the struggle for power which is reflected in human nature. In Politics Among Nations: The Struggle for Power and Peace, he observes, "International politics, like all politics, is a struggle for power....whenever [politicians] strive to realize their goal by means of international politics, they do so by striving for power." 23 Power is depicted as anything that aids in the control of man over man. It can be measured in terms of a state's ability to influence other states. Realists attribute order in the international system to the distribution of power. Power is measured in terms of military capacity, wealth, size, and control over resources. States deploy power resources in pursuit of their interests. Calculations about power dominate the decisions of leaders as states compete amongst themselves for power. Regime patterns are thus subject to the distribution of power between states.

\footnotetext{
${ }^{21}$ Morris Goldstein, The Global Effects of Fund-Supported Adjustment Programs: IMF Occasional Paper 42 (Washington, D.C.: International Monetary Fund, 1986).

${ }^{22}$ Michael Donelan, Elements of International Political Theory, (Oxford: Oxford University Press, 1990), 36.

${ }^{23}$ Hans Morgenthau, Politics Among Nations: The Struggle for Power and Peace, $5^{\text {th }}$ edition (New York: Alfred A. Knopf, 1978), 27.
} 
In Scientific Man Versus Power Politics, Morgenthau explains that international politics has not outgrown the "pre-liberal" stage of development and he demonstrates how anarchy in the international environment has prevented the success of liberal organizations such as the League of Nations. ${ }^{24}$ Morgenthau also questions the replacement of traditional diplomacy with a more "scientific" approach to international affairs. He sees very little promise in the international conferences organized by the League of Nations and other groups seeking to conduct open, multilateral negotiations on the problems facing states. In a criticism of Wilson and other advocates of collective security, he states that it is the practice of nations to "clothe their own particular aspirations and action in the moral purposes of the universe." 25 He concludes that the clear separation of morality and politics is necessary to allow theorists to distinguish between truth and idolatry. Morgenthau rejects ethics or ideology as an explanation for state actions. As an alternative, "realism imposes the judgment that statesmen think and act in terms of interest defined as power." 26

Morgenthau refers to balance of power behavior as "not only inevitable, but an essential stabilizing factor in a society of sovereign nations."27 Balancing implies some level of cooperation, and Morgenthau argues, "Given such a system, no nation will agree to concede political advantages to another nation without the expectation, which may or

\footnotetext{
${ }^{24}$ Hans Morgenthau, Scientific Man Versus Power Politics, (Chicago: Chicago University Press, 1946).

${ }^{25}$ Hans Morgenthau, "Six Principles of Political Realism," in Classic Readings of International Relations, eds. Phil Williams, Donald Goldstein, and Jay Shafritz (Fort Worth, TX: Harcourt Brace College Press, 1994), 38.

${ }^{26}$ Hans Morgenthau, Politics Among Nations, 5.

${ }^{27}$ Ibid, 167.
} 
may not be well founded, of receiving proportionate advantages in return. ${ }^{28}$ Because of the unforgiving nature of competition, interstate cooperation is commonly viewed as a zero-sum game. States may cooperate with each other on occasion, but generally only when these arrangements result in "balanced" or "equitable" gains. Equitable gains are those reflecting the relative power of the states.

Waltz provides a neorealist view on the formation and maintenance of regimes in Theory of International Politics. ${ }^{29}$ Neorealists emphasize the importance of the structure of the international system, as determined by the distribution of power among states. Unlike Morgenthau, Waltz does not assume that states are inherently aggressive because they are driven by a lust for power; he points out that their behavior is simply the result of a wish to survive in an anarchic environment. Whereas human nature is the underlying cause of insecurity in Morgenthau's view of realism, anarchy plays that role in Waltz's theory. Waltz observes that wars can occur in anarchy "because there is nothing to prevent them... [and therefore] force serves, not only as the ultima ratio, but indeed as the first and constant one." 30

The anarchical nature of the international system means that states can only guarantee their survival through their own efforts to maximize their power relative to other states. Once the survival of the state is assured, states seek to achieve other goals such as tranquility and prosperity. This emphasis on self-sufficiency serves as a barrier to cooperation. Waltz writes, "The impediments to collaboration may not lie in the

\footnotetext{
${ }^{28}$ Ibid, 179.

${ }^{29}$ Kenneth Waltz, Theory of International Politics (Reading, MA: Addison-Wesley Press, 1979).

${ }^{30}$ Ibid, 113.
} 
character and the immediate intention of either party. Instead, the condition of insecurity - at the least, the uncertainty of each other's future intentions and actions - works against cooperation." ${ }^{31}$ States remain conscious of relative gains when collaborating with other states. "When faced with the possibility of cooperating for mutual gains, states that feel insecure must ask how the gain will be divided...If an expected gain is to be divided, say in the ratio of two to one, one state may use its disproportionate gain to implement a policy intended to damage or destroy the other." 32

Waltz argues that actors in a self-help world have trouble cooperating because of their concern with relative gains, but that this concern depended upon how much actors feared that other countries could use their gains against them. Much research has been done to identify the conditions under which a state will prefer relative or absolute gains. Grieco introduces a variable " $k$ " to represent this sensitivity to the gap between absolute and relative gains. He argues that this sensitivity has six main sources, including such things as whether the partner has been an ally or adversary in the past, whether partners perceive a common enemy, how they perceive the trajectory of future power relations, and the convertibility of various types of influence. ${ }^{33}$

Waltz finds that conflict among states is best explained not by the internal characteristics of individual states, but by the distribution of power in the international

\footnotetext{
${ }^{31}$ Ibid, 113.

${ }^{32}$ Ibid, 105.

${ }^{33}$ Joseph Grieco, Cooperation Among Nations: Europe, America, and NonTariff Barriers to Trade ( Ithaca, NY: Cornell University Press, 1990). A similary variable " $\mathrm{r}$ " is used to explore this sensitivity in Duncan Snidal, "International Cooperation Among Relative Gain Maximizers" International Studies Quarterly 35 (1991): 387-402.
} 
system. He argues that a bipolar system is less prone to conflict than a multipolar system, because this structure reduces the uncertainties and miscalculations that can lead to war. Anarchy encourages great powers to behave defensively and to maintain rather than upset the balance of power. He finds that "the first concern of states is to maintain their position in the system."34 The importance of relations between any two states is reduced in a bipolar system because great powers do not fear the loss of smaller allies. The great powers will neither over-react ("chain-gang") nor under-react ("pass the buck") in response to threats to smaller allies, as they are more likely to do in multipolar systems. ${ }^{35}$ The polarity of power distributions within the international system may vary, with greater polarity increasing the cohesion among alliance members. This approach leads Waltz to see the bipolar balance of power itself as responsible for the relative peace during the Cold War rather than the characteristics of individual states or organizations. ${ }^{36}$

Waltz accepts that international regimes can serve useful functions on behalf of their members, but he does not think of the resulting organizations as important international actors in themselves. This leads to the conclusion that international regimes are shaped and limited by their member states and have little independent effect. State power remains the most important factor in determining the relationship of states to

\footnotetext{
${ }^{34}$ Waltz, Theory of International Politics, 95.

${ }^{35}$ Thomas Christenson and Jack Snyder, "Chain Gangs and Passed Bucks: Predicting Alliance Behavior in Multipolarity," International Organization 44, no. 2 (Spring 1990): 136-168.

${ }^{36}$ It is important to note that Waltz's view on the peaceful nature of bipolar distributions of power are not universally shared by realists. Gilpin argues that bipolarity can lead great powers to react strongly to marginal threats in the belief that even small losses affect the credibility of commitments. In his view, multipolarity induces more fluid balancing behavior and uncertainty regarding each states commitment to its alliances to deter the use of force. See Robert Gilpin, War and Change in World Politics (Cambridge: Cambridge University Press, 1981).
} 
regimes. Regimes are created to increase the power or influence of dominant states within a specific issue area. The regimes themselves regimes have only marginal effects on anarchy and the willingness of states to cooperate. Neorealists accept that powerful states may use regimes to advance their interests, but they do not feel that states are constrained by them. Regimes are thought to have little impact in areas of fundamental conflict or on occasions when gains from unilateral action outweigh those achieved through cooperation. States, their interests, and the international distribution of power are seen as the primary determinants of national security, and this explains how and under what circumstances states cooperate.

Mearsheimer also rejects classical realism's reference to aggressiveness in human nature as the source of international conflict in The Tragedy of Great Power Politics. ${ }^{37}$ Mearsheimer finds that the desire for survival in an anarchic international environment serves as a sufficient explanation for interstate conflict without the need to debate the nature of man. States are driven to seek more power to maximize their odds of survival. He observes that in an anarchical international system, there is uncertainty regarding both the capabilities and intentions of other states. Mearsheimer maintains, "Another state may be reliably benign, but it is impossible to be certain of that judgment because intentions are impossible to divine with one hundred percent certainty." ${ }^{38}$

Mearsheimer characterizes his form of realism as "offensive realism". He emphasizes military power over other forms of national power. "In international

\footnotetext{
${ }^{37}$ John Mearsheimer, The Tragedy of Great Power Politics (New York: Alfred A. Knopf Press, 1948).

${ }^{38}$ John Mearsheimer, "The False Promise of International Institutions," in Theories of War and Peace, ed. Michael Brown (Cambridge, MA: MIT Press, 1999), 335.
} 
politics... a state's effective power is ultimately a function of its military forces and how they compare with the military forces of rival states." ${ }^{39}$ Mearsheimer refers to other forms of power (such as economic wealth and population) as "latent power" that is most significant in its ability to be transformed into military power. In a departure from Waltz, Mearsheimer finds that "status quo powers are rarely found in world politics, because the international system creates powerful incentives for states to look for opportunities to gain power at the expense of rivals, and to take advantage of those situations when the benefits outweigh the costs. Each state's goal is to be the hegemon in the system." This behavior contributes to the creation of "security dilemmas" where an increase of power of one state results in suspicious and hostile reactions from others, particularly among great powers. Under these conditions cooperation is limited and relative capabilities become the primary concern of a state. Since today's ally could become an adversary in the future, states are wary of agreements that may provide greater gains to other states. Each state pursues policies that attempt to maximize a state's power relative to other states, and the cycle continues.

Mearsheimer accuses regimes of promoting a false sense of security, because they can be used by states to maximize their relative power, while remaining in the event that states fail to live up to their commitments. Cooperation is difficult under anarchy because states are unable to accurately assess the intentions of other states, and there is no central authority to appeal to if another state fails to live up to its agreements.

\footnotetext{
${ }^{39}$ John Mearsheimer, "Offensive Realism," University of Chicago Magazine 94 , no 3 (2002): 12. ${ }^{40}$ Ibid, 13.
} 
Participation is based on the self-interest of the state; members decide which behavior will most effectively promote their strategies and their interests. He argues that international regimes are less a consequence of collective will than a reflection of the distribution of power in the international system.

Many realists concur with the assertion that cooperation emerges from the concentration of power or the practice of balance of power politics rather than from the value of the agreements themselves. International norms and rules reflect dominant state interests and therefore have no independent authority from which to enforce compliance. Realists such as Carr argue that in the absence of centralized authority, the strongest country is willing and able to promote regimes that serve as an extension of its power. Carr states, "Any international moral order must rest on some hegemony of power." ${ }^{41}$ In a condition of unipolarity, realists expect a hegemon to create and enforce regimes to ensure international stability and preserve its favorable status. The actual substance of the regime is a projection of the dominant country's particular preferences. A hegemon can enforce regime compliance through coercion or incentives such as side payments. Hegemonic stability theory credits a single dominant state with the successful formation of international regimes.

While realists emphasize hegemony in terms of material factors, such as a preponderance of military and economic resources, other scholars are likely to include ideational factors such influence over the creation and maintenance of international norms. Ikenberry and Kupchan view hegemony as a social process. "Hegemonic control

\footnotetext{
${ }^{41}$ E. H. Carr, The Twenty Years' Crisis, 1919-1939: An Introduction to the Study' of International Relations, (New York: Macmillan Press, 1946), 168.
} 
emerges when foreign elites buy into the hegemon's vision of international order and accept it as their own - that is, when they internalize the norms and value orientations espoused by the hegemon and accept its normative claims about the nature of the international system...Power is thus exercised through a process of socialization in which the norms and value orientations of leaders in secondary states change and more closely reflect those of the dominant state." ${ }^{42}$ They find that socialization complements material power noting, "Rule based on might is enhanced by rule based on right. Furthermore, it is less costly., 43

Critical scholars present alternate views of hegemony that expand the statecentered concept centered in realism. Cox ascribes to the critical school of theorists that reject the positivist assumption that the aim of social science is to identify causal relationships in an objective world. According to Smith, critical scholars point out that is it not possible "to separate the subject from object, nor to distinguish between normative inquiry on the one hand and empirical scientific research on the other." ${ }^{44}$ Gramsci, who is the source for Cox's conception of hegemony, draws on Marxism in his portrayal of hegemony as the dominance of one social class over another. In his work, hegemony is exercised through intellectual and moral leadership that is translated into political power for the dominant class. Robert Cox describes how domestic hegemony can expand to

\footnotetext{
42 John Ikenberry and Charles Kupchan, "Socialization and Hegemonic Power," International Organization 44 no. 3 (Summer 1990): 285.

${ }^{43}$ Ibid, 286

${ }^{44}$ Steve Smith, "The Self-Images of a Discipline: A Genealogy of International Relations Theory" in International Relations Theory Today, ," eds. Ken Booth and Steve Smith (Cambridge: Polity Press: 1995), 24-6.
} 
world hegemony. Cox interprets hegemony as social phenomenon expressed "in norms, institutions, and mechanisms which lay down general rules of behavior for states and for those forces of civil society that act across national boundaries, rules which support the dominant mode of production. ${ }^{, 45}$ Cox argues that hegemony may be imposed or consensual, adding that "dominance by a powerful state is a necessary but not a sufficient condition of hegemony."46

Several scholars have examined the unique role of hegemony in the creation of international regimes. Kindleberger provides a classic illustration of hegemonic stability theory in study on the role of hegemonic leadership in the Great Depression. ${ }^{47} \mathrm{He}$ finds that one of the main factors contributing to the severity of the Great Depression was the absence of a hegemonic state to lead the world economy. The United States was able but unwilling to provide economic order in the world during the interwar years, while Great Britain was willing but unable to play the role of hegemon. Gilpin's presentation of hegemonic stability theory provides another realist view on the relationship between regimes and the international balance of power. Gilpin's hegemonic stability theory finds that international order rests on one powerful state, which dominates all other states through its preponderance in military and economic capabilities. ${ }^{48}$ Gilpin portrays a hegemon as a powerful state who plays a unique role in preserving of the stability of the

${ }^{45}$ Robert Cox, "Social Forces, States and World Orders," Millennium: Journal of International Studies 10 no 2, (1981): 137.

${ }^{46}$ Ibid, 139.

${ }^{47}$ Charles Kindleberger, The World in Depression: 1929-1939 (Berkeley: University of California Press, 1973).

${ }^{48}$ Robert Gilpin, War and Change in World Politics (Cambridge: Cambridge University Press, 1981 ). 
international system. In his study of American hegemony in the mid-to-late twentieth century, he finds evidence that the United States used "its power and influence to promote trade liberalization and a stable international monetary system primarily in order to advance its own political and economic interests." ${ }^{49}$ His assumption that international regimes require the efforts of a powerful leader leads to the expectation that there is likely to be less compliance with international regimes as the hegemon's power declines.

A second example of hegemonic leadership in Ruggie's account of changes to international economic regimes from "orthodox liberalism" to "embedded liberalism" during the European reconstruction after the Second World War. ${ }^{50}$ Ruggie documents changes in the international regimes governing liberal economics. In this instance of regime change, the United States exercised hegemonic leadership by unilaterally defining the rules and procedures of the "embedded" liberal economic regime and using its dominant economic position to bring it about. A new economic order resulted from the ability of the hegemon to entice or coerce other states into complying with regimes that were consistent with its vision of a desirable international order. Elsewhere, Ruggie notes, "The American vision as to what constitutes a desirable world order has been clear and consistent, and it embodies certain key multilateral principles: movement toward greater openness, greater nondiscrimination of treatment, and more extensive opportunities to realize joint gains. It does not include endowing multilateral

\footnotetext{
${ }^{49}$ Robert Gilpin, "The Rise of American Hegemony," in Two Hegemonies: Britain 1846-1914 and the United States 1941-2001, ed. Patrick O'Brien and Armand Clesse (Aldershot: Ashgate Publishing, Ltd., 2002), 166.

${ }^{50}$ John Ruggie, "International Regimes, Transactions, and Change: Embedded Liberalism in the Postwar Economic Order," International Organization 36 no. 2 (Spring 1982): 379-415.
} 
organizations with extensive autonomy." American leadership in the post-Cold War era. Kagan finds that "to be effective, multilateralism must be preceded by unilateralism. In the toughest situations, the most effective multilateral response comes when the strongest power decides to act, with or without the others, and then asks its partners whether they will join., ${ }^{, 52}$

International regimes often become a public good provided unilaterally by the hegemon. Public goods have the characteristics of non-excludability and non-rivalry. Non-excludability where it is not possible to provide a good for one actor without all others having access to it. Non-rivalry is the condition where the consumption of a good by one actor will not interfere with others access to it. Regimes will persist so long as such a power concentration exists; regimes will decline with the diffusion of international power. Regimes may also dissipate the hegemon's resources, which Krasner finds will allow an existing regime to persist until the hegemon's control over relevant resources declines, after which the regime collapses. ${ }^{53}$ Without the efforts of a hegemon to enforce a regime, regimes are likely to be disregarded when national interests conflict with compliance, particularly when security concerns are present.

Realism is pessimistic regarding the formation of international regimes without hegemonic leadership because these regimes result in a reliance on other states for their survival. This behavior is inconsistent with realism's views on the self-help nature of

\footnotetext{
${ }^{51}$ John Ruggie, "Third Try at World Order? America and Multilateralism After the Cold War," Political Science Quarterly 109, no. 3 (Fall 1994): 560.

${ }^{52}$ Robert Kagan, “The Benevolent Empire," Foreign Policy 111 (Summer 1998): 33.

${ }^{53}$ Stephen Krasner, "Regimes and the Limits of Realism: Regimes as Autonomous Variables”', in International Regimes, ed. Stephen Krasner (Ithaca, NY: Cornell University, 1983).
} 
international relations. To the extent that non-state actors are considered by realists, they are generally believed to have little long-term influence on how such state patterns of action are developed. When cooperation occurs, it is led by a hegemon, and predominantly reflects the hegemon's concerns. This pessimism towards regimes has led some scholars to question the continued relevance of NATO, including several who predict the imminent demise of NATO. Others point out that the Alliance may only persist until a crisis makes its shortcomings clear. As Walt notes, "An aging alliance may appear robust and healthy so long as its formal institutions continue to operate, even if the basic rationale for the arrangement is crumbling.",54

In summary, power-based regime analysis is favored by realists and neo-realists. These theorists generally characterize the formation of international regimes as a means of promoting the interests of particular member states. Regime formation and regime change can be viewed as functions of the existing distribution of power and the interests of the dominant states in a particular issue area. In the case of a single dominant state, hegemonic stability theory claims that the hegemon will seek to create and enforce regimes to ensure international stability and preserve its favorable status. International regimes often become a public good provided unilaterally by the hegemon through coercion or incentives such as side payments. Without the efforts of a hegemon to enforce a regime, regimes will be routinely disregarded. The balance of power and the efforts of hegemon to actively enforce regime compliance thereby become key factors in successful regime change.

\footnotetext{
${ }^{54}$ Stephen Walt, "Why Alliances Endure or Collapse," Survival 39 no. 1 (Spring 1997): 167.
} 
On the occasions when such regimes are formed, many realists expect them to last only as long as the distribution of power and perception of threat remain constant. Pedersen notes "Structural realism has some particularly weak spots, the case of European integration being one... [due to] its inability to provide an explanation of the high degree of institutionalization and notably its durability in the European region." Neoliberal institutionalism provides an complementary approach to realism's powerbased approach to regime analysis. This body of work depicts regimes as more than a consequence of the balance of power, but as a source of international order valued for their ability to allow states to cooperate for mutual gains.

Neoliberal Institutionalism and Organization-based regime analysis

Neoliberal institutionalism refers to a body of work addressing the formation and maintenance of international regimes. This theoretical approach depicts the international system as made up of states existing under anarchy, but it allows regimes a more independent role in the international environment. Neoliberal institutionalism examines the incentives that states face that both promote and deter cooperation, and the role that regimes play in facilitating this process. While realists see regimes as the creation of powerful states who seek to preserve their interests, neoliberal institutionalists view regimes as arising out of mutual desires to achieve better outcomes through cooperation. Regimes "do not merely reflect the preferences and power of the units constituting them;

\footnotetext{
55 Thomas Pedersen, Germany, France and the Integration of Europe: A Realist Interpretation (London: Pinter Press, 1998), 30.
} 
the institutions themselves shape those preferences and that power." ${ }^{, 56}$ Neoliberal institutionalists do not assume that rules alone drive behavior, but that states seek regimes to acquire the benefits of cooperation. These arrangements allow members to focus on maximizing absolute gains with less concern about relative gains.

This approach to regime analysis assumes regimes exist to allow participants to take collective action to achieve joint gains or to avoid joint losses. While hegemonic states may have particular incentives to bring regimes into existence, relatively small groups of states can also overcome collective action problems and form regimes. Snidal employs game theory in his research to depict the interaction of states and the role of like-minded groups to form regimes to address common concerns. ${ }^{57}$ The balance of power is not as important as the desire to achieve joint gains from cooperation. Absolute gains can be sought without undue concern for relative gains. Neoliberal institutionalists view regimes as arrangements to encourage international cooperation, and moderate the effects of anarchy. These regimes give states an alternative to acting alone and help to overcome the distrust and competition among states that threaten their security. Regimes help states cooperate to mutually achieve their goals and the organizations promoting regimes serve as important actors in the international environment. The rise in both the authority and number of international organizations in the aftermath of World War II has been the subject of much discussion among neoliberal scholars.

\footnotetext{
${ }^{56}$ Robert Keohane, “International Institutions: Two Approaches," International Studies Quarterly 32, no. 4 (December 1988): 382.

${ }^{57}$ Duncan Snidal, "The Limits of Hegemonic Stability Theory," International Organization 39, no. 4 (Autumn 1985): 579-614.
} 
In After Victory, Ikenberry describes the creation of a new international order that "hinges on the ability of states to restrain power institutionally and bind themselves to long-term commitments." ${ }^{\text {58 }}$ He finds that regimes constrain the actions of all members, including a hegemon. Although the United States has a preponderance of power, members of multilateral organizations such as NATO are less likely to engage in competitive security policies with other participants in the regime. Rather than seeking gains in zero-sum situations, the allies work together to combine their capabilities in a manner that expands a liberal international order. Ikenberry finds that realism and neoliberal institutionalism provide competing explanations for the proliferation of regimes following World War II and he shows how an institutionalist approach more accurately accounts for the post-Cold War international cooperation.

Ikenberry's claim is supported by the continued expansion of NATO and other international security organizations, the absence of conflict between Western states, and the general acknowledgement of the power restraining functions of these regimes. He views the regulative role of regimes as more important than shifts in the balance of power. Even though the United States held an influential role in the regime, "the actual exercise of that power was sufficiently constrained and institutionalized and the possibilities of reassurance sufficiently available that cautious cooperation rather than outright power balancing was possible." ${ }^{, 59}$ By creating forums and decision-making

\footnotetext{
${ }^{58}$ John Ikenberry, After Victory: Institutions, Strategic Restraint, and the Rebuilding of Order after Major Wars (Princeton: Princeton University Press, 2001), xi.

${ }^{59}$ Ibid, 222.
} 
procedures that promote common interests while simultaneously limiting their members' ability to act unilaterally, regimes shape the international environment.

While realists seek to predict international behavior based on power and interests alone, neoliberal institutionalists such as Keohane and Nye find the international disposition toward regimes to be affected by levels of interdependence. ${ }^{60}$ They define the components of complex interdependence as mutual sensitivity and mutual vulnerability. Sensitivity is the extent to which one state is affected by the actions of another, while vulnerability is the extent to which a country can isolate itself from external events. At higher levels of interdependence, the opportunity costs of not coordinating policy are greater and grow to exceed the costs of making agreements and sacrificing autonomy. As a result, there is a higher demand for international regimes in an environment of high interdependence. As the number and importance of related issues increases, the formation of regimes becomes more desirable than the alternative of creating new rules and procedures for each issue that arises.

Regimes coordinate the behavior of states and help make cooperation possible even within an international system based on anarchy. Regimes promote interstate cooperation that will allow states to overcome conflicts over interests as depicted in the logic problems such as Rousseau's "Stag Hunt". ${ }^{61}$ While Rousseau accurately described the incentives for defection based on a single encounter, neoliberal institutionalists point out that the expectation of repeated interactions creates an incentive for cooperation over

\footnotetext{
${ }^{60}$ Robert Keohane and Joseph Nye, Power and Independence: World Politics in Transition (Boston: Little Brown, 1977).

${ }^{61}$ Jean Jacques Rousseau, Discourse on the Origin and Basis of Inequality Among Men, reprinted in The Social Contract and the First and Second Discourse. (New Haven, CT: Yale University Press, 2002).
} 
time. States that defect undercut their overall reputation for cooperation, weakening not only the regime they violate but others as well. As long as the stakes remain fairly uniform in each round and reliable information on other states' actions is available, states will be less likely to defect and risk the benefits of maintaining existing regimes. ${ }^{62}$ Regime compliance continues as long as the costs of compliance remain lower than the benefits provided, including future benefits associated with stability. Short term gains are sacrificed for the expectation of even larger joint gains being realized through compliance with a regime.

In After Hegemony: Cooperation and Discord in the World Political Economy, Keohane explores concerns about the stability of international order following the seemingly dramatic decline of American hegemony in the 1970s. ${ }^{63}$ Keohane utilizes an organization-based rather than a power-based approach to regime analysis to explain how international regimes can endure and evolve, even when circumstances that gave rise to them have changed. He identifies the obstacles to international cooperation as uncertainty, informational asymmetries, and fears of cheating. International regimes continue to persist even without hegemonic oversight because of their ability to help overcome collective action and market failure dilemmas. ${ }^{64}$ Regimes influence "the flow of information and opportunities to negotiate; the ability of governments to monitor

\footnotetext{
${ }^{62}$ Andrew Bennett and Joseph Lepgold, "Reinventing Collective Security After the Cold War and Gulf Conflict," Political Science Quarterly 108, no. 2 (September 1993): 217.

${ }^{63}$ Robert Keohane, After Hegemony: Cooperation and Discord in the World Political Economy (Princeton: Princeton University Press, 1984).

${ }^{64}$ For more information on collective action and market failure see Mancur Olson, The Logic of Collective Action: Public Goods and the Theory of Groups (Cambridge, MA: Harvard University Press, 1965).
} 
others' compliance and to implement their own commitments - hence their ability to make credible commitments in the first place; and prevailing expectations about the solidarity of international agreements." ${ }^{65}$ In short, regimes aid cooperation by reducing both transaction costs and information costs while giving states access to a greater set of capabilities as a result of their collective efforts.

Regimes reduce transaction costs by creating a forum and set of procedures for negotiations. These activities help states to overcome obstacles such as information asymmetries, moral hazards and irresponsibility, making governments' policies more transparent and predictable to other members. As a result of these existing forums and procedures, states can more easily negotiate future agreements. Regimes reduce information costs by providing forums to discuss and disseminate information. In addition, regimes create a sense of legal liability that obligates actors to the rules and agreements making up the regime. Neoliberal institutionalists argue that states reject cooperation primarily because of fears of cheating and that regimes can reduce the attractiveness of cheating by emphasizing reciprocity. Keohane finds that "international regimes reduce transaction costs of legitimate bargains and increase them for illegitimate ones." ${ }^{, 66}$ Under these conditions, regimes deter cheaters and protect victims, so that states can create and maintain mutually-beneficial agreements. This approach to international regimes implies that the persistence of regimes is greatly influenced by the ability of the

\footnotetext{
${ }^{65}$ Keohane, After Hegemony, 2.

${ }^{66}$ Ibid, 90.
} 
organizations that embody them to provide information and coordinate member actions that allow all member states to achieve benefits.

Although Keohane emphasizes interstate economic cooperation, organizational approaches to regime analysis have been effectively adapted to security affairs. Despite the existence of anarchy, regimes can influence the behavior of states in a manner that reduces uncertainty and increases security. Regimes "can facilitate cooperation by assuring states that gains are evenly divided over time, for example by disclosing information about the military expenditures and capacities of alliance members." Keohane, Nye and Hoffman demonstrate how some security regimes influence the exercise of state power by providing a forum for governments to signal their intentions and promoting information sharing to make policies more predictable. ${ }^{68}$ International regimes promoting security often result in the formation of organizations that provide a means for verifying military capability, for discussing intentions, and resolving disputes among member states. International security regimes not only promote the pursuit of greater absolute gains, but encourage collective responses to international security challenges that offer advantages over unilateral responses anticipated by states operating in an anarchic international environment.

The ability of regimes to overcome the condition of anarchy and promote cooperation among states is not universally accepted among theorists. In Cooperation Among Nations: Europe, America, and Non-Tariff Barriers to Trade, Grieco explores the

\footnotetext{
${ }^{67}$ Robert Keohane and Lisa Martin, "The Promise of Institutionalist Theory," International Security 20 no. 1 (Summer 1995): 45-6.

${ }^{68}$ Robert Keohane, Joseph Nye, and Stanley Hoffman, eds. After the Cold War: International Institutions and State Strategies in Europe, 1989-1991 (Cambridge, MA: Harvard University Press, 1993).
} 
question of how and why states are willing to cooperate in an anarchical international system. ${ }^{69}$ Grieco examines both realism and neoliberal institutionalism, to determine which best explains the problem of international cooperation. Grieco tests the neoliberal institutionalist assertion that international regimes can promote cooperation by reducing conflict and allowing states to seek absolute gains. The subject of Grieco's study is trade negotiations, which are a topic of "low politics" generally favored by neoliberal institutionalists. He states, "Realist theory is typically the form of analysis that is brought to bear on relations between adversaries, and, except for analyses of military alliances, realism is not usually applied to relations among states that are on friendly terms." Since his findings tend to be more consistent with realism in a domain that is thought to favor neoliberal institutionalism, his conclusions gained particular interest within the discipline.

Grieco finds that throughout the negotiations that he studied, international regimes were not capable of mitigating the effects of anarchy. This behavior could be expected to be even more pronounced when there are security implications to such an agreement. He concludes that neoliberals misunderstand the influence of anarchy on the preferences and actions of states. "Neoliberalism mis-specifies the effects of anarchy on the character and goals of states." 71 He argues that realism provides a better explanation because this theory addresses both concerns with cheating and the gaps in relative gains.

\footnotetext{
${ }^{69}$ Joseph Grieco, Cooperation Among Nations: Europe, America, and NonTariff Barriers to Trade (Ithaca, NY: Cornell University Press, 1990).

${ }^{70}$ Ibid, 2-3.

${ }^{71}$ Ibid, 2.
} 
Elsewhere, he notes, "Most states concentrate on the danger that relative gains from joint action may advantage partners and may thus foster the emergence of what at best might be a potentially more domineering friend and at worst could be a potentially more powerful adversary. ${ }^{72}$ Grieco's argument fails to recognize that the effects of anarchy have been tempered, if only locally, through international regimes that provide a credible security pledge. In the case of NATO, Joffe finds "The United States swept aside the rules of the self-help game that had governed and regularly brought grief to Europe in centuries past.... Once the problem of security was dispatched, collective gain could overwhelm the zero-sum logic of rivalry and relative gains." 73

In summary, an organization-based approach to regime analysis is favored by neoliberal institutionalists. These theorists characterize regime creation and enforcement as resulting from a process of multilateral bargaining through which all member states seek long term benefits in the form of joint gains or lowered costs. Neoliberal institutionalist theory centers on questions of interstate cooperation, which can be portrayed as efforts to achieve more optimal outcomes in light of both common and conflicting interests. International regimes govern the actions of all participating states uniformly, including placing constraints on the behavior of a hegemon. Participating states comply with international regimes, even taking actions that conflict with short-term national interests, to pursue the benefits of long term cooperation. Regimes persist due to their ability to draw upon relevant capabilities in order to provide absolute gains for all

\footnotetext{
72 Joseph Grieco, "Anarchy and the Limits of Cooperation: A Realist Critique of the Newest Liberal Institutionalism" International Organization 42 no. 3 (Summer 1988): 499.

${ }^{73}$ Joseph Joffe, The Limited Partnership: Europe, the United States, and the Burdens of Alliance (Cambridge, MA: Ballinger Publishing Co., 1987), 183-4.
} 
member states rather than simply providing relative gains for the hegemon. Regime change comes about as regime participants recognize that existing structures and procedures can be adapted to promote new instances of collective behavior.

Organization-based regime analysis thereby emphasizes the ability of the organizational structures to meet the needs of all members when presented with the opportunity for collective action.

Neoliberal institutionalism complements other theoretical perspectives allowing for the influence of norms and other social phenomenon in international relations. This approach emphasizes rules and organizational characteristics less than social interactions. Kowert points out that "many neoliberal theorists have thus been particularly reluctant to focus on informal structure and norms in the area of security studies." ${ }^{74}$ Keohane offers another critique, stating "Institutional theory takes states' conceptions of their interests as exogenous: unexplained within the terms of the theory...nor does realism predict interests. The weakness of systemic theory, of both types, denies us a clear test of their relative predictive power." ${ }^{, 75}$ Constructivism is a useful means of understanding the formation of interests through its emphasis on the social nature of international relations and the importance of identities and norms in the constitution of national interests.

\footnotetext{
${ }^{74}$ Paul Kowert, "Norms, Identity, and Their Limits," in The Culture of National Security: Norms and Identity in World Politics, ed. Peter Katzenstein (New York: Columbia University Press: 1996), 461.

${ }^{75}$ Robert Keohane, "Institutional Theory and the Realist Challenge After the Cold War," in Neorealism and Neoliberalism: The Contemporary Debate. Ed. David Baldwin (New York: Columbia University Press, 1993), 285.
} 
Liberal thought originated during the Enlightenment and is characterized by a belief in progress and that through cooperation, individuals can improve their condition and learn to live in peace. Liberals generally view human beings as perfectible and history as a progression toward the eventual elimination of war through education and reform. Early liberal theorists questioned the relationship of the individual and the state and developed new perspectives on social and economic affairs. Their view of human nature depicts a basic unity of interests among individuals, which results in common interests among states. Liberals find that individual interests cannot be confined within the borders of one state, and the actions of individuals create both formal and informal linkages across state borders. Liberals recognize that the internal characteristics of states vary considerably and that these differences have significant effects on state behavior toward regimes. These scholars claim that regime compliance is not dependent on repetitive cost-benefit analyses, but the result of patterns of interaction resulting in shared norms. These interactions can reduce the sense of competition between them and promote peaceful relations and closer integration.

While realists viewed the outbreak of World War II as evidence of the intractability of balance of power politics, post-war liberal thinkers such as Mitrany and Haas emphasize that interdependence among states would continue to give regimes an important role in the pursuit of international peace. In A Working Peace System, Mitrany observes that modern states are characterized by "multiple channels of access" which 
weaken the grip of central decision makers on foreign policy. ${ }^{76}$ These states are increasingly dependent on one another to achieve their goals of economic growth and social security for their citizens. Rather than viewing the state as a unitary actor, he emphasizes that authority is decentralized within states as well as among states. Mitrany shows how regimes embodied in such organizations as the International Labor Organization promote international cooperation because they perform key social and economic functions that are outside of the authority of individual states. Integration in one sector of the economy creates pressure for integration in related sectors, a process termed "functional spillover." Political integration can be expected to follow economic and social integration. Mitrany's views, labeled functionalism, predict an increase in political integration at the expense of state sovereignty. Regimes promoting integration could limit the effects of anarchy and create conditions more favorable to increased international cooperation.

In Beyond the Nation-State, Haas draws on functionalism as he examines the process of regime formation through the early experiences of the European Community (EC). Haas finds that supranational bodies like the EC are "the appropriate regional counterpart to the nation state which no longer feels capable of realizing welfare aims within its own narrow borders." 77 He anticipates increasing authority at the supranational level as a result of economic integration among European states. Haas' neofunctionalism depicts organizations as actively promoting regimes leading to political integration,

\footnotetext{
${ }^{76}$ David Mitrany, A Working Peace System (Chicago, Quadrangle Press, 1943).

${ }^{77}$ Ernst Haas, Beyond the Nation-State: Functionalism and International Organization. (Stanford, CA: Stanford University Press, 1964), 158.
} 
primarily as a result of domestic economic groups pursuing their own interests across state borders. Successful economic integration causes individuals and groups to begin to shift their loyalty from national authorities to supranational authorities, a process termed "political spillover." Political spillover results in strong supranational organizations that can enforce order as an alternative to the dominance of anarchy as the principle guiding interstate cooperation.

In Political Community and the North Atlantic Area, Deutsch and a team of researchers analyze a number of historical case studies in an effort to identify conditions favorable to the formation of security communities. These authors define a security community as "one in which there is real assurance that the members of that community will not fight each other physically, but will settle their disputes in some other way."78 Within these communities, states become interdependent and create regimes to govern their relations in accordance with shared norms, values and expectations. Integration comes through "the attainment, within a territory of a sense of community and of institutions and practices strong enough and widespread enough to assure for a long time, dependable expectations of peaceful change among its population" ${ }^{, 79}$ This integration is "the basis of economic interdependence, rough compatibility of values among decision makers, mutual predictability of behaviors among said decision makers, and some degree of mutual policy responsiveness."

\footnotetext{
${ }^{78}$ Karl Deutsch, et al, Political Community and the North Atlantic Area: International Organization in the Light of Historical Experience (Princeton: Princeton University Press, 1957). 5.

${ }^{79}$ Karl Deutsch, The Analysis of International Relations (Englewood Cliffs, NJ: Prentice Hall, 1968), 5. ${ }^{80}$ Ibid, 58.
} 
Deutsch found that regimes can assist in the formation of security communities. Deutsch argues that trade and other forms of intercultural exchange can help develop a sense of community which makes the use of violence less likely as a means to resolving conflict. He finds that "the main value of functional organizations today may well be in their side-effects, especially in forming habits of communication and responsiveness...such organizations also help to increase the range of different common functions and services, with the organizations to carry them out." ${ }^{, 81}$ International cooperation can become so "frequent and rewarding" that it mitigates trends toward conflict and may even lead to more direct forms of political integration. ${ }^{82}$

Deutsch found that although the North Atlantic area was far from integrated, it seemed to be moving toward closer integration. Historically, regimes complement the process of integration, but are not sufficient for integration. However, even in the early years of the Alliance, the efforts of member states to increase their economic and social cooperation in addition to its security functions made it more than a military alliance. Deutsch felt that there were good prospects for increased integration among NATO members as the Alliance adopted more characteristics of a collective security regime. He acknowledged that the Soviet threat gave security cooperation greater urgency, but he did not view it as a necessary condition for closer integration. Deutsch states, "Planners might find that they could move ahead more vigorously if they dropped what may be a tacit assumption that both the danger of an East-West war and the opportunity for

\footnotetext{
${ }^{81}$ Ibid, 189.

${ }^{82}$ Ibid, 155 .
} 
integrating the North Atlantic area will disappear at the same moment. ${ }^{, 83}$ In his view, increased security cooperation through NATO "may be one of the most effective ways to advance the development of political community in the North Atlantic area, and to contribute to the eventual abolition of war." 84

Many scholars have observed the remarkable record of peaceful relations among democratic states, implying the existence of a democratic community governed by its own norms. Owen combines normative and organizational explanations to argue that liberal principles and democratic processes work together to make war highly unlikely among democracies. ${ }^{85}$ His observations apply to states where liberalism is the dominant ideology and citizens have leverage over decisions to wage war. Declarations of war are institutionalized and provide numerous opportunities for liberal ideals of peaceful competition, persuasion, and compromise to be acted upon. Relations among Western democracies have been particularly characterized more by peaceful cooperation than by considerations of balance of power.

Constructivism complements liberalism in its depiction of the shared interests and peaceful behavior of democratic states toward each other. What liberals characterize as democratic values are viewed by constructivists as shared interests and norms. According to Lebow, realism, neoliberal institutionalism and constructivism all share a

\footnotetext{
${ }^{83}$ Ibid, 191.

${ }^{84}$ Ibid, 203.

${ }^{85}$ John Owen, "How Liberalism Produces Democratic Peace," International Security 19, no. 2 (Autumn 1994): 87-125.
} 
common ontology consisting of egoistic, autonomous states. ${ }^{86}$ However, while both realism and neoliberal institutionalism emphasize material factors in the formation and maintenance of regimes, constructivists generally believe international relations are governed by shared ideas. The constructivist ontology asserts reality is social rather than material. As a result, the outcome of state relations can be attributed to the influence of ideas instead of such material factors as wealth, geography, and military technology.

In The Culture of National Security: Norms and Identity in World Politics, Katzenstein and others argue that norms play an important role in world politics, shaping both cooperation and conflict in ways that are not accounted for by theories that focus either on material structural forces or on individual choice. ${ }^{87}$ Norms "serve as collective understandings of appropriate behavior, which can be invoked by the participants in a discourse to justify their arguments." 88 Over time, commonly agreed and jointly observed principles and norms become internationalized by the actors involved, thereby reshaping the perception of interests. ${ }^{89}$ Hurrell similarly finds that states comply with international regimes "not based on external sanctions or the threat of them but based rather on the existence of shared interests, of shared values, and of patterned

\footnotetext{
${ }^{86}$ Ned Lebow, The Tragic Vision of Politics: Ethics, Interests and Orders (Cambridge: Cambridge University Press, 2003).

${ }^{87}$ Peter Katzenstein, ed., The Culture of National Security: Norms and Identity in World Politics (New York: Columbia University Press, 1996).

${ }^{88}$ Thomas Risse-Kappen, "Collective Identity in a Democratic Community," in The Culture of National Security: Norms and Identity in World Politics, ed. Peter Katzenstein (New York: Columbia University, 1996), 369.

${ }^{89}$ Volker Rittberger, "Regime Theory: Findings from the Study of East West Regimes," Cooperation and Conflict, 26 no. 4 (Autumn 1991): 165-83.
} 
expectations." ${ }^{90}$ In the international environment, the perceived legitimacy of rules and their underlying norms influence the willingness of international actors to comply. Regimes are thus credited with being self-enforcing in that they manage to socialize their members into compliance. ${ }^{91}$

The constructivist emphasis on social factors can be employed to generate new understandings regarding the formation of interests and the pursuit of security. Buzan concurs with realist assertions that individuals and states seek security, but he views the concept of security as more complex and multifaceted than the straightforward pursuit of power. Buzan also challenges the realist depiction of states as functionally equivalent, noting that states differ not just in their physical characteristics, but in terms of their organizing ideologies and their legitimacy among their own population. ${ }^{92}$ The pursuit of national security involves reducing vulnerability and threats, which may be military, political, economic, societal, or environmental. In his work with Waever and Wilde, Buzan describes the process of securitization. ${ }^{93}$ An issue becomes securitized when it is deemed an exception to the normal political processes. Securitization follows the logic of constructivist speech-act processes, wherein an actor designates a referential object as an existential threat and an audience accepts this claim. Buzan's work provides a useful

\footnotetext{
${ }^{90}$ Andrew Hurrell, "International Society and the Study of Regimes A Reflective Approach," in Regime Theory and International Relations, ed. Volker Rittberger (Oxford: Clarendon Press, 1990), 190.

${ }^{91}$ Oran Young, Compliance and Public Authority: A Theory with International, Applications (Baltimore, MD: Johns Hopkins Press, 1979).

92 Barry Buzan, People States and Fear: An Agenda for International Security Studies in a Post-Cold War Era, $2^{\text {nd }}$ Edition (Boulder, CO: Lynne Reinner Publishers, 1991), 70-1.

${ }^{93}$ Barry Buzan, Ole Waever, and Jaap de Wilde, Security: A New Framework for Analysis, Analysis (Boulder, CO: Lynne Reinner Publishers, 1998), 34-42.
} 
account of how individuals, states, and communities pursue security in a complex manner that may involve many issues and interests.

Buzan, Waever, and Wilde also introduce the concept of a "security complex" to explain changes and variations in state behavior as it relates to the pursuit of security. Security complexes are shaped by the balance of power and interactions among actors that result in patterns of cooperation and conflict. A security complex is a "set of units whose process of securitization is so interlinked that security problems cannot be resolved apart from one another." 94 In some of their most recent work, Buzan and Waever suggest that regional security complexes are increasingly useful to an understanding of state behavior. ${ }^{95}$ Regional security complexes exist as "miniature anarchies" when states' geographical proximity and history of interaction motivate them to put added emphasis on their relations with selected states. The authors recognize a tendency to greater integration within regional security complexes, which is a step towards forming a security community. This is particularly relevant to relations among European states, which have gradually formed heterogeneous complexes across numerous issue areas embodied in international regimes such as the European Union (EU) and NATO.

Constructivism portrays international relations as a social process made up of agents and structure. The world is constructed through the actions of agents. These actions occur based on the meanings that the objects and situations have for them. The

\footnotetext{
${ }^{94}$ Ibid, 12.

${ }^{95}$ Barry Buzan and Ole Waever, Regions and Powers: The Structure of International Security (Cambridge: Cambridge University Press, 2003).
} 
structure of the system consists of the identities of these agents and the ideas that give meaning to their material capabilities. The process of identity creation is continually shaped by the interactions of actors and their experiences. One result of positive experiences with interstate cooperation can be the formation of an international community. Hurrell states, "The aim is to identify a conception of international society consistent with self-interest and with the realities of power. Yet, at the same time, there was the awareness that international society could not be understood solely in these terms and had to be rooted within the cultural and historical forces that had helped shape the consciousness of society and had molded perceptions of common values and common purposes." ${ }^{96}$ Constructivists commonly view states as agents having a collective identity, based on common elements of their national identities. States form their collective identity based on how they see themselves in relation to other states in international society, and this identity affects the way they determine their interests.

Constructivism emphasizes the important role of identity in the formation of actors' interests. According to Wendt, both realism and neoliberal institutionalism regard state interests and identities as "constant and exogenously given" while constructivists view them as "endogenous to interaction., 97 A recognition that identities and interests may be treated as dependent variables endogenous to interaction allows constructivists to "treat collective action not merely as a problem for changing the price of cooperation for

\footnotetext{
${ }^{96}$ Andrew Hurrell, "International Society and the Study of Regimes: A Reflexive Approach," in Regime Theory and International Relations, eds.Volker Rittberger and Peter Mayer (Oxford: Clarendon Press: 1995), 63

${ }^{97}$ Alexander Wendt, "Collective Identity Formation and the International State," American Political Science Review' 88, no. 2. (Summer, 1994): 384.
} 
self-interested actors, but as a process of creating new definitions of self." 98 He and other constructivists argue that interests cannot simply be deduced from assumptions about anarchy, but are rooted in identity. Wendt finds that any cohesive group (whether national, subnational, or transnational) will be built around some type of collective identity. State interactions continually produce and reproduce conceptions of "self" and "other", resulting in the continuous redefinition of identities and interests. In this way, state interests and identities are co-constituted along with the social structures of the international system.

In A Social Theory of International Relations, Wendt acknowledges that anarchy exists in the international system, but he finds that collective identities may influence anarchy. ${ }^{99}$ He identifies three cultures of anarchy: enmity, rivalry, or friendship. The collective identity of states determines the dominant culture of anarchy and the levels of conflict and cooperation will vary accordingly. Collective identity formation is influenced by a number of variables, including interdependence, common fate, homogenization, and self-restraint. While realists view regimes as a product of changes in power or threat, constructivists view regimes as emerging out of collective identities. Identity is therefore a critical element in social and political interactions, aiding in an understanding of how individuals come together to form groups and how states come together to form regimes.

\footnotetext{
${ }^{98}$ Ibid, 387.

${ }^{99}$ Alexander Wendt, Social Theory of International Politics (Cambridge: Cambridge University, 1999).
} 
Onuf pioneered rule-oriented constructivism, arguing that international relations can be analyzed according to the rules invoked or challenged by agents' speech acts. ${ }^{100}$ Rules assist in the formation of identities and interests. Onuf identifies several types of rules, including instruction rules, directive rules and commitment rules that guide the behavior of agents. Speech acts reflect how agents deal with rules, by either by complying or not complying with existing rules or contributing to rule changes.

International regimes are sets of stable rules that specify relationships between agents. These regimes can take many forms, including collective defense and collective security arrangements between states.

Regimes emerge as states develop mutual expectations of cooperation as a result of their experiences with each other. Initial experiences with cooperation among states develop into norms that encourage further cooperation over time. Regimes emerge from the choices agents make and entail the mutual acceptance of norms of behavior. International security organizations such as NATO and the European Union provide a means for states to increase their security at the cost of complying with the norms of the regime. These norms include a commitment to consultation and compromise based on the premise that "no nation has either the inherent strength or the special moral authority to decide important international issues without the consent of other states."101 Constructivism recognizes the inevitable change in both international regimes and collective identities as a result of routine state interactions.

\footnotetext{
${ }^{100}$ Nicholas Onuf, World of Our Making Rules and Rule in Social Theory and International Relations (Colombia, SC: University of South Carolina Press, 1989).

${ }^{101}$ Philip Gordon and Jeremy Shapiro, Allies at War: America, Europe and the Crisis in Iraq (New York:McGraw-Hill, 2004), 52.
} 
Collective identities are based on shared norms, leading liberals and constructivists to expect democracies to form international organizations reflecting their sense of community. This sense of community provides insight into the relationship between identity, interests and regimes. Some scholars find that the basis of Western unity lies in NATO's commitment to defend common values such as representative democracy, rule of law and the market economy. ${ }^{102}$ In many ways, NATO is a contemporary embodiment of the "pacific federation" described in Kant's Perpetual Peace, resulting in differences between the relations of liberal and non-liberal states. Nye observes, "The United States shares the values of democracy and human rights more thoroughly with the majority of European countries than most other states. Values matter in American foreign policy and the commonality of values between the United States and Europe is an important force keeping the two sides together."103 Doyle's contribution to democratic peace theory notes that liberal states view each other as just, but "because non-liberal states are in a state of aggression with their own people, their foreign relations become for liberal governments deeply suspect. In short, fellow liberals benefit from a presumption of amity; nonliberals suffer from a presumption of enmity." 104

Constructivists depict the Cold War as a clash of distinct identities and interests derived from these identities. NATO's collective identity helped to sustain a sense of community among NATO members during numerous economic and military crises

\footnotetext{
102 Owen Harries, "The Collapse of the 'West'," Foreign Affairs 72 (September/October 1993): 41-53.

${ }^{103}$ Joseph Nye, "The U.S. and Europe: Continental Drift?" International Affairs 76, no. 1 (January2000): 55.

${ }^{104}$ Michael Doyle, "Liberalism and World Politics," American Political Science Review' 80, no. 4 (December 1986): 1161.
} 
In summary, norm-based regime analysis is favored by both liberals and

constructivists. Both perspectives foresee the emergence of security communities among democratic states. The presence of a regime may result in the mutual adjustment of national interests favoring the preservation of the international community. Regimes can affect states' interests by influencing ideas about the legitimacy of member state actions when compared to established norms. Shared values among participating members can influence member state behavior over time and contribute to regime formation and changes to existing regimes. The process of adopting a collective security regime within NATO has been a social process, involving a reconceptualization of security, identity and interests among member states. While a collective defense regime implies a collective response to an overt act of aggression from a known threat, the practice of collective security is more complex and introduces new challenges for the Alliance.

\section{Distinguishing Collective Security and Collective Defense Regimes}

Literature in the field of international relations recognizes a number of potential approaches to establishing international order. Balance of power behavior is commonly observed among states in a perpetual condition of competition and conflict. States may form alliances as a means of externally balancing against other groups of states. Collective defense is practiced through an international security regime whereby states pledge their cooperation and support in the event that an alliance member is attacked by a third party. Collective defense regimes generally emphasize military coordination among a limited number of states and are organized in response to a specified threat. An alternative regime is the creation of a collective security community that assumes responsibility for the preservation of peace. An ideal collective security arrangement 
calls upon all states to share in the responsibilities for peace and international order and obligates all members to punish any transgression. Collective security regimes generally seek to restrain threats to international peace originating from either within or outside of the alliance. Kupchan characterizes a collective security regime as one "based on the principle of all against one; that members will build up military capability against an aggressor should one emerge." 105 Collective security arrangements commonly obligate members to act in response to any perceived threat to international peace, including emerging threats not anticipated during the formation of the agreement. While the practice of collective defense predates the modern state system, collective security has consistently been proposed as an alternative approach establishing a peaceful international order.

The call for a new international order based on the practice of collective security has a long history in international relations. In the early $18^{\text {th }}$ century, Saint-Pierre proposed a strong federation among European states that would enforce international law and have the authority to arbitrate disputes among states. He regarded war as an evil practice that stood in the way of further political and social reform in Europe. In $A$ Project for Perpetual Peace, Saint-Pierre proposes that European monarchs appoint representatives to a Senate of Peace that would mediate disputes within the federation as an alternative to war. ${ }^{106}$ His work is one of the earliest attempts at collective security, as

\footnotetext{
${ }^{105}$ Charles Kupchan, "The Case for Collective Security," in Collective Security After the Cold War, ed. George Downs (Ann Arbor, MI: University of Michigan Press, 1993), 120.

${ }^{106}$ Abbe de Saint-Pierre A Project for Perpetual Peace (1713). Reprinted in Steven Cooper, ed. Peace Projects of the Seventeenth Century (New York: Garland Press, 1974).
} 
he calls for member states to unite their military forces against individual states that refuse to obey international law as interpreted by the Senate for Peace.

Saint-Pierre's project argues for the adoption of collective security regimes by emphasizing the tragedy of war, but was unable to convince European monarchs to renounce war as a means of resolving international conflicts. Saint-Pierre views war as an unsuitable means of resolving conflict due to its extraordinary social and economic costs. He assumes that self-interested monarchs would prefer a system of mediation once they are made aware of "the immense advantages which a perfectly certain peace would bring to them and to their Royal Houses." 107 As it turned out, these advantages were not generally acknowledged among monarchs, and the difficulties of implementing such a collective security continued to challenge liberal thinkers.

Rousseau's works describe the potential benefits of a social reorganization on both the domestic and international levels. In Social Contract, Rousseau views human nature as perfectible through "political will". ${ }^{108}$ Under the social contract, people submit themselves to the general will in order to live in a peaceful society. Rousseau states, "What man loses through the social contract is his natural liberty and an unlimited right to everything that tempts him and that he can acquire. What he gains is civil liberty and the proprietary ownership of all he possesses."109 Rousseau characterizes legitimate government as the expression of the general will. However, when Rousseau sought to

${ }^{107}$ Ibid, 16.

${ }^{108}$ Jean-Jacques Rousseau, Discourse on the Origin and Basis of Inequality Among Men (1754). Reprinted in The Social Contract and the First and Second Discourses, ed. Susan Dunn (New Haven, CT: Yale University Press, 2002).

${ }^{109}$ Ibid, 164. 
extend the social contract to the international level in Perpetual Peace, he encountered a number of obstacles. While a strong federation of European states was necessary to end interstate war, he recognized that war often provided personal benefits to the rulers of these states. As described in his allegory of the stag hunt, individuals often abandon collective duty for the sake of individual gain. The same behavior at the international level undermines collective security. Rousseau observed, "Kings are concerned with two objects alone: to extend their rule abroad or to make it more absolute at home." Although the idea of a federation committed to maintaining peace seemed the most promising approach to eliminating war, Rousseau saw no real possibility that European states would willingly concede their sovereignty.

Kant was able to overcome the challenge expressed by Rousseau and other theorists by arguing that the establishment of "pacific federations" would be an inevitable result of human progress in Thoughts on Perpetual Peace. ${ }^{111}$ Kant anticipates the creation of a peaceful international order built on representative democracies, international law and economic interdependence. Republican constitutions eliminate the waging of wars based on the whims of monarchs. International law contributes to the development of norms respecting the rights of both citizens and republics. Economic interdependence creates transnational ties that encourage states to accommodate each other rather than going to war.

${ }^{110}$ Ibid, 102-3.

${ }^{111}$ Immanuel Kant, Eternal Peace and Other International Essays (1795). Reprinted in Eternal Peace and Other International Essays (Boston: The World Peace Foundation, 1914), 84-5. 
Kant argues that "powerful and enlightened people" organized as "a republic, which by its very nature must be disposed in favor of perpetual peace" would be more pacific. ${ }^{112}$ Citizens of republics would have greater influence over their governments and would "be very loath ... to bring upon themselves all the horrors of war." ${ }^{113}$ Kant recognized that wars involve large costs and impose suffering on the population of a state that its leaders often do not appreciate. Leaders that are forced to consult with their citizens are more likely to become aware of the benefits of peace and respect for international law. Kant therefore felt that republics were uniquely suited to form a federation that would maintain the rights of each state and decrease the likelihood of war as it expanded to include more republics. According to Kant the world would eventually escape from "occasions of war" by establishing "public coercive laws" applying to "an ever-growing state of nations, such as would at last embrace all the nations of the earth." 114

Kant's collective security arrangement functions differently than traditional alliances or Hobbes' Leviathan. He finds that the pursuit of peace makes it "necessary to establish a federation of peoples [to] protect each other against external aggression... [going beyond an] alliance which can be terminated at any time." $115 \mathrm{He}$ argues that peace is possible even in the absence of a supreme international authority. Rather than empowering a separate authority, states themselves would enforce

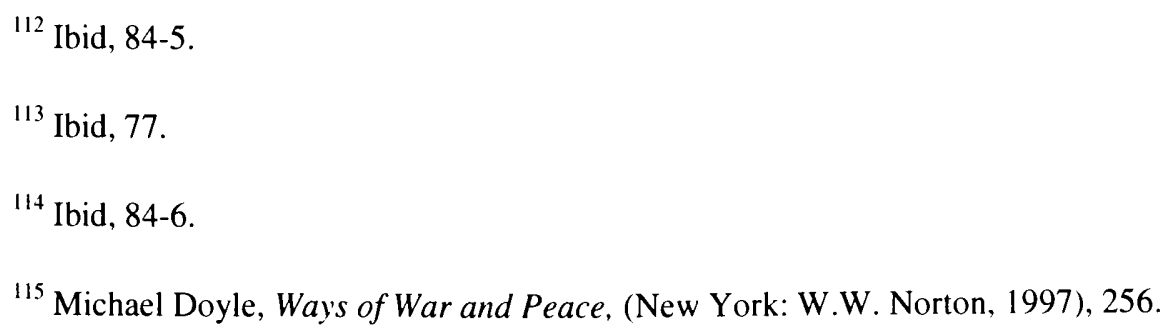


international peace. He proposes an arrangement wherein all states would be obligated to act against an aggressor, because every state's security interests are believed to be affected by such aggression. Kant describes this as "a system of international right founded upon public laws conjoined with power, to which every state must submitaccording to the analogy of the civil or political right of individuals in any one state."116 This federation would facilitate open diplomacy, relying on discussion and arbitration to settle conflicts in a lawful manner.

Like Kant, Bentham tended to perceive liberal states as more benign in their international conduct than traditional states. Democracies, as opposed to authoritarian governments, were thought to behave in a manner more compatible with the interests of humanity. Bentham advocates a collective security arrangement similar to that of Kant, promoted by democratic states where disputes would be mediated according to international law in a "Common Court of Judicature". 17 Along with Kant, his writings are viewed by many as the foundation for President Woodrow Wilson's thoughts on collective security that were eventually embodied in the League of Nations.

Wilson shared Kant and Bentham's view of progress and believed men and women could invent solutions for all of mankind's problems, including war. Like Kant, he advocated the replacement of unstable balance-of-power arrangements with an international community of states. In pursuing collective security as an alternative to balance of power politics, Wilson adopted the concept that security is indivisible.

\footnotetext{
${ }^{116}$ Kant, Eternal Peace and Other International Essays, 65.

117 Jeremy Bentham, An Introduction to the Principles of Morals and Legislation (1781). Reprinted in An Introduction to the Principles of Morals and Legislation (Indianapolis, IN: Hackett Publishing, 1988).
} 
Wilson's approach to foreign policy emphasized American leadership in the promotion of a collective security regime, but he was unable to bring the United States into such an organization. While Wilson succeeded in bringing the League of Nations into existence, a lack of hegemonic leadership and enforcement authority limited its ability to carry out its mandate and ultimately led it its irrelevance as relations among member states deteriorated in the years preceding the outbreak of the Second World War. Despite increasing evidence of interstate cooperation, collective security has continued to draw criticism since the failure of the League of Nations to prevent the outbreak of World War II.

In an ideal collective security community, ideological and cultural factors would not affect the willingness of states to act. Viotti and Kauppi characterize such a system as "the collective commitment of a group to hold its members accountable for the maintenance of an internal security norm." 118 The practice of collective security requires a broad commitment to restoring the status quo. Wight emphasizes the effort to maintain the status quo in his definition of collective security as "a system in which any breach of the peace is declared to be of concern to all the participating states, and an attack on one is taken as an attack on all." 119 A collective security regime implies the existence of an inclusive community wherein all members are committed to resist or overwhelm any act of aggression through coordinated action.

\footnotetext{
${ }^{118}$ Paul Viotti and Mark Kauppi, eds., International Relations Theory: Realism, Pluralism, Globalism (New York: MacMillan, 1993), 48.

${ }^{119}$ Martin Wight, Systems of States, (London: Leiscester University Press, 1977), 149.
} 
Much of the pessimism regarding the practice of collective security stems from differences between reality and these ideal conditions. In a study of historical attempts to invoke collective security commitments, Wight finds little reason for optimism. Both ancient and modern collective security regimes were "entirely ineffective, as every system of collective security has been." ${ }^{120}$ One reason for these failures is identified by Joffe, who finds that states "do not elevate the punishment of wrong-doers above all other values, and they are loath to sacrifice their particular interests on the altar of abstract justice." ${ }^{21}$ Jakobson, the former Finnish ambassador to the United Nations, expresses little hope for the success of collective regimes, even among European states. In his experience, "international organizations remain abstractions unless brought to life by the national will of the member states...the reality is that, although politicians pay lip service to the idea of collective action in defense of common values or of the principle of collective security, nations will take up arms only when their own national interests are directly threatened." 122

Claude has written extensively on collective security and collective defense regimes and expresses pessimism regarding the success of collective security in practice. He points out that collective security has historically been pursued after a period of extended conflict, as the victors attempt to cement their dominant position. "Collective security is the ideology of a coalition that is at or near the point of winning a major

\footnotetext{
${ }^{120}$ Ibid, 62.

${ }^{121}$ Josef Joffe, "Collective Security and the Future of Europe: Failed Dreams and Dead Ends," Survival (Spring 1992): 39.

${ }^{122}$ Max Jakobson, "Collective Security in Europe Today." Washington Quarterly 18 no. 2 (Spring 1995): 62.
} 
war...[but] the zeal for accepting the responsibilities of membership in a collective security system is ephemeral... a passing fancy, briefly entertained by victors in coalition wars." 123 The successful practice of collective security in the post-Cold War period implies that interstate relations have fundamentally changed since 1815,1919 , or 1945.

Claude finds that two principles of collective security tend to contradict each other in practice. "Respect for the principle of collectivism would impel a state to remain passive in the face of what it regarded as aggression, if no collective determination of the fact of aggression and authorization of counteraction were forthcoming. Adherence to the collective security maxim that anybody's aggression threatens everybody's stake in world order would impel a state to take action on the basis of its own judgment that aggression had occurred, even without benefit of collective legitimization." ${ }^{24}$ Reminiscent of Morgenthau, Claude concludes that contemporary statesmen have not been able to adopt an outlook that suits the practice of collective security. He states, "Collective security's promise of guaranteed security and stable peace is highly attractive, but the world has discovered that its leaders and peoples do not really put peace unconditionally above justice in their scale of values, or believe that peace is indivisible." 125

Claude finds that a collective security system is incompatible with collective defense, because collective security calls for replacing balance of power arrangements and collective defense regimes, which are by definition exclusive, with an inclusive

\footnotetext{
${ }^{123}$ Inis Claude, "Collective Security after the Cold War," in Collective Security in Europe and Asia, ed. Gary Guertner (Carlisle Barracks, PA: Strategic Studies Institute Press, 1992).

${ }^{124}$ Inis Claude, "The Collectivist Theme in International Relations," International Journal, 24 (1969): 655.

${ }^{125}$ Inis Claude, "The Balance of Power Revisited," Review' of International Studies 15 (1989): 83.
} 
community. Collective security requires the defense of all against all. In Power and International Relations, Claude states, "The world is conceived not as a we-group and a they-group of nations, engaged in competitive power relations, but as an integral wegroup in which danger may be posed by 'one of us' and must be met by 'all the rest of us'." ${ }^{26}$ Collective security involves a pact against war involving the entire international community, all of whom pledge to oppose future aggression. He notes, "The abstractness of the enemy is a leading characteristic of collective security." ${ }^{127}$ In contrast, a collective defense regime obligates states to organize their defenses against one or more identifiable external threats. Lagon similarly distinguishes collective security systems, which are organized to deal with threats from within the system, from collective defense alliances which are formed against external threats. ${ }^{128}$ Cold War NATO is characterized as a "specified" collective defense system, while post- Cold War NATO is more accurately portrayed as an "unspecified" collective defense system. Collective defense of this kind is concerned with creating a pledge for united action against one or more unspecified external aggressors.

Kissinger also views collective security as an arrangement that is fundamentally inconsistent with collective defense. "Traditional alliances were directed against specific threats and defined precise obligations for specific groups of countries linked by shared national interests or mutual security guarantees. Collective security defines no particular threat, guarantees no individual nation, and discriminates against none. It is theoretically

\footnotetext{
${ }^{126}$ Inis Claude, Power and International Relations (New York: Random House, 1962), 114.

${ }^{127}$ Inis Claude, Swords into Plowshares (New York: Random House, 1971 ), 257.

${ }^{128}$ Mark Lagon, “The Illusions of Collective Security,” The National Interest 40 (Summer 1995): 50-61.
} 
designed to resist any threat to the peace, by whoever might pose it and against whomever it might be directed." ${ }^{29}$ He finds that collective security requires that all states share the same perception of a crisis and are equally prepared to take action regardless of risks to national interests. Since this rarely occurs in the international system, Kissinger observes that "no act of aggression involving a major power has ever been defeated by applying the principle of collective security" and he cautions against NATO incorporating these principles into its doctrine. ${ }^{130}$ Kissinger finds NATO "has become more akin to a collective security organization, like the United Nations, than to a traditional alliance." 131 He is critical of NATO's attempts to "graft a system of collective security on top of an alliance system," stating that "this has never worked no matter how cleverly legal points are argued."132

In NATO Transformed - The Alliance's New Roles in International Security, Yost also characterizes NATO as migrating from a collective defense regime to a collective security regime in the aftermath of the Cold War. ${ }^{133}$ Yost finds that the need for regime change is amplified by the question of NATO's relevance after the end of the Cold War. During the Cold War, he depicts NATO as primarily focused on establishing military capabilities to deter Soviet aggression and, if necessary, to conduct military operations in

\footnotetext{
${ }^{129}$ Henry Kissinger, Diplomacy (New York: Simon and Shuster, 1994), 247.

${ }^{130}$ Ibid, 249.

${ }^{131}$ Henry Kissinger, “A Dangerous Divergence,” The Washington Post, December 10, 2002.

${ }^{132}$ Henry Kissinger, "Letter to the Editor," The Washington Post, July 23, 1997.

${ }^{133}$ Yost, David. NATO Transformed - The Alliance's New Roles in International Security (Washington D.C.: United States Institute of Peace Press, 1998).
} 
defense of allied territory. NATO's exclusive preoccupation with collective defense had less appeal following the dissolution of the Soviet Union, leading Alliance leaders to seek to adopt other regimes. NATO's transformation came in the 1990s with its commitment to assuming responsibility for the preservation of peace outside of its borders.

While he recognizes that NATO has not yet transformed into a Kantian or Wilsonian system of universal collective security, Yost argues that the allies have adopted the ideology of collective security, including "the idea that 'security is indivisible'."134 Yost expresses concern that the pursuit of collective security is not sustainable in the long run because it is inconsistent with collective defense and could damage the cohesion and effectiveness of the Alliance. He views NATO's new missions as "a subject of discord among allies unwilling to commit resources to preparing for what seem to be improbable or secondary contingencies." ${ }^{235}$ He finds an unavoidable tension between the goals of inclusiveness and effectiveness, which may become unmanageable and lead to the failure of both regimes. In his view, "NATO risks surrendering its military effectiveness in a relatively small, close-knit collective defense pact at the expense of the inclusiveness collective security requires."136 This concern was commonly expressed during the debate over NATO expansion. Senator Jesse Helms remarked during U.S. Senate debate over NATO expansion in 1998, "We are not inviting new nations into the NATO that won the Cold War but rather into a diluted NATO converted from a well-defined military alliance into a nebulous collective security

\footnotetext{
134 Ibid, 293.

${ }^{135}$ Ibid, 277.

${ }^{136}$ Ibid, xii.
} 
arrangement". ${ }^{137}$ The pursuit of both collective security and collective defense risked introducing complications that could damage relations between member states and hasten the decline of the alliance.

An alternative approach to avoiding the potential contradictions between these security regimes is for NATO to abandon collective defense in favor of collective security. The exclusive nature of collective defense can be portrayed as provocative to non-member states, which is unnecessary given the democratic aspirations of Russia and former Warsaw Pact states. Kupchan argues for a reorganization of NATO along the lines of a collective security system responsible for "peacekeeping and peace enforcement; confronting external threats as well as those that might arise from within." 138 These changes would enable NATO member states to focus on what have become the most common security tasks for the Alliance rather than the increasingly remote risk of an attack by a hostile Russia. Kupchan claims, "The elimination of NATO's Article 5 guarantee would weaken the Alliance's deterrent power, but as long as Russia continues to pose no danger to Central or Western Europe, the tradeoff makes sense." 139

While these scholars have argued that collective defense and collective security are inherently incompatible, others are more open to combining these regimes. Gulick argues that collective security, "far from being alien to the "age-old tradition of the

\footnotetext{
${ }^{137}$ Allison Mitchell, "NATO Debate" From Big Risk to Sure Thing," The New York Times, March 20, 1998.

${ }^{138}$ Charles Kupchan, "Reviving the West," Foreign Affairs 75 no. 3 (May/June 1996): 97-98.

${ }^{139}$ Ibid, 100.
} 
balance of power, not only derives out of the latter, but also must be regarded as the logical end point of the balance-of-power system, the ideal toward which it has been moving, slowly and haltingly, for several hundred years."140 Similarly, Wright views collective security as "a planned development of the natural tendency of balance of power policies," rather than being a distinct approach to international order. ${ }^{141}$ Finally, Hampton points out that while international security regimes may serve the minimal function of collective defense, they all have not been created for that purpose exclusively. ${ }^{142}$ These theorists are comfortable with international organizations pursuing multiple regimes along with a multitude of objectives and argue for more optimism regarding the likelihood of such a regime change for NATO.

\section{Conclusion}

This chapter has served to clarify the scope of this research and place it in context with other international relations scholarship. Relevant regime theory literature has been examined, yielding three-part typology of approaches to regime analysis. This chapter has also served to distinguish the regimes of collective defense and collective security as they apply to the dilemmas facing NATO in the post-Cold War era.

Subsequent chapters examine the changes in NATO as a function of factors emphasized in power-based, organization-based, and norm-based approaches to regime analysis. A power-based approach views regimes as a means for promoting the interests

\footnotetext{
${ }^{140}$ Edward Gulick, Europe's Classical Balance of Power (Ithaca, NY: Cornell University Press, 1955), 307-8.

${ }^{141}$ Quincy Wright, Tbe Study of International Relations (New York: Appleton-Century-Crofts, 1955), 163.

${ }^{142}$ Mary Hampton. The Wilsonian Impulse: U.S. Foreign Policy, the Alliance, and German Unification. (Westport, CT: Praeger Press, 1996).
} 
of a hegemon and emphasizes the efforts of the hegemon to the maintenance and perpetuation of an international regime. Many aspects of international regimes can be viewed as a public good, requiring the hegemon to bear disproportionate responsibility for the organization and enforcement of the regime. A power-based approach based in realism suggests that the process of regime change will be a result of determinations by the hegemon that such a change is consistent with their national interests along with a willingness to bear the burdens of this change. In the absence of hegemonic leadership, a regime may fail to come into existence or will be unable to adapt to changing circumstances. An organization-based approach based in neoliberal institutionalism emphasizes the contributions of rules and decision-making procedures to the behavior of regime participants. These rules and procedures can promote collective action in numerous issue areas and can guide the process of regime change. The process of regime change is influenced by the organization's access to relevant capabilities. An international regime is unlikely to evolve in a direction that does not complement the existing capabilities of the member states and organizational bodies. Finally, a normbased approach to regime analysis based in liberalism and constructivism views regimes as a social phenomenon driven by a commitment to common principles and norms. This approach to regime analysis links the process of regime change to interactions among states and the formation of collective identities rooted in shared values. Concurrence on the objectives to be pursued by the regime as well as the means to achieve these objectives is related to an ongoing sense of community among member states and influences their commitment to the regime. 
NATO embodies a transatlantic security regime that links the United States, a global hegemon, with Canada and much of Europe. Over the past several decades, NATO member states have demonstrated an ongoing commitment to collective defense while introducing aspects of a collective security regime. The three dominant approaches to regime analysis identified in this chapter are employed throughout this study to gain an understanding of the process of regime change in NATO both during and after the Cold War, with an emphasis on reforms favoring the practice of collective security. The analysis emphasizes how these approaches complement each other to provide a wellreasoned account for member state behavior throughout each of the periods of study, and ultimately serve as a basis for conjecture regarding the future of the Alliance. 
We were all brought up, I think, in a Cold War and we knew that the Alliance was essentially static, pretty linear, pretty defensive, and in its philosophy, pretty reactive. Is this the right mindset for the Alliance in the 21st Century?

- General James Jones, NATO Supreme Allied Commander Operations (2005)

\section{Chapter 2: NATO During the Cold War}

A thorough analysis of recent changes within NATO and informed forecasting of its future necessitates an understanding of the Alliance's history. NATO underwent numerous changes on its way to embracing a collective security regime and many of the factors associated with power-based, organization-based, and norm-based approaches were present during this evolution. NATO was organized in response to a unique set of challenges facing the United States and Europe in the late 1940s. A convergence of interests resulting from the perception of a growing Soviet threat, helped to overcome nationalist divisions and forge a transatlantic relationship through an unprecedented peacetime security regime. This chapter will examine the security environment in Europe that led to the creation of the North Atlantic treaty and changes in both internal and external conditions that resulted in the Alliance's evolution in subsequent decades. This inquiry examines the manner in which NATO has adapted both its strategy and its organizations in response to internal and external pressures. These changes were generally intended to increase the security of Alliance members while maintaining unity within the Alliance. This review of NATO's evolution throughout the twentieth century finds the allies remaining committed to a regime of collective defense security while increasingly engaging in activities associated with the practice of collective security. The culmination of this evolutionary process was the creation of an international organization 
increasingly willing to venture into collective security undertakings as NATO member states attempted to cope with post-Cold War international security challenges.

\section{European Security After World War II}

NATO grew out of the wartime alliance between the United States, the Soviet Union, China, France, and Great Britain. Even while the war was still underway, western leaders gave considerable thought to the organization of an international order to maintain international peace following the end of hostilities. In 1943 British Prime Minister Winston Churchill declared in a speech at Harvard University, "It would be a most foolish and improvident act on the part of our two Governments, or either of them, to break up this smooth-running and immensely powerful machinery the moment the war is over.... We are bound to keep it working and in running order after the war-probably for a good many years." A similar vision was expressed by President Roosevelt in his call for the "four policemen" (United States, Soviet Union, Great Britain, and China) to enforce a post-war peace and prevent a relapse back into war and anarchy. The institutionalization of this wartime alliance first took the form of the United Nations (UN).

The UN was founded as the fulfillment of Churchill and Roosevelt's shared vision. Roosevelt had believed that each of these allies, including the Soviets, could constructively contribute to post-war reconstruction and the pursuit of a more peaceful global order. Discussions among London, Moscow, and Washington in the summer of 1944 eventually yielded a consensus on the UN's purpose and organizational structure.

\footnotetext{
${ }^{1}$ Richard Best, Cooperation With Like-Minded Peoples: British Influences On American Security Policy, 1945-1949 (New York: Greenwood Press, 1986), 28.
} 
During the Dumbarton Oaks discussions in Washington, D.C., the allies completed their plans for the division of responsibilities among the UN Security Council, the General Assembly and UN Secretariat. France was invited to join the Security Council, thereby sharing the burdens and responsibilities of the other victors of World War II. While the UN was introduced with great optimism, it soon became apparent that it was ill equipped to fulfill its mandate.

While still in its infancy, the UN was prevented from creating the conditions for a stable peace in Europe by the ideological conflict between East and West. Time after time, the UN proved incapable of countering Soviet aggression due to the UN's lack of access to military forces and the USSR's veto within the Security Council. The Soviets continued to undermine the conduct of free elections in Eastern Europe and refused to fulfill existing agreements to include non-Communists in the governments of Romania and Bulgaria. Rather than promoting self-determination among European states, the Soviet Union was seeking to increase its control in the occupied states. NATO's first General Secretary, Lord Hastings Ismay, later observed, "It was proving impossible to reach agreement with the Soviets on any international issue... From behind the Iron Curtain came nothing but slander and bullying."2 Paul Henri Spaak, the second Secretary General of NATO, also viewed the intractability of the Soviets as a key contributor to the call for a new alliance structure. He noted that every village and town in Europe should erect a statue to Joseph Stalin because he was the true father of the

\footnotetext{
${ }^{2}$ Hastings Ismay, NATO: The First Five Years, 1949-1954 (Utrecht, NE: Bosch-Utrecht Press, 1955), 6.
} 
NATO alliance. ${ }^{3}$ Western leaders were initially reluctant to confront the Soviets due to the imbalance of forces in Europe immediately following the war.

While the United States and Western European states rapidly demobilized following the end of World War II, Soviet forces were maintained at their wartime levels. Within a year, American forces in Europe were reduced from over three million men to less than four hundred thousand. British forces were reduced from nearly one and one half million to less than half a million troops. In contrast to this rapid demobilization, the Soviet Union kept some five million troops in the armed forces after the war. A year after the war the Soviets had 30 divisions in Eastern Europe, 175 divisions in the western Soviet Union and another 125 divisions in strategic reserve. ${ }^{4}$ The military might of the Soviet Union, teamed with Stalin's aggressive policies, drove Western leaders to seek new security arrangements to counter Soviet advances.

In March 1946, Prime Minister Churchill warned of the descent of an "iron curtain" over Eastern Europe that would require a coordinated response from Great Britain and the United States. The wartime annexation of Estonia, Latvia, and Lithuania had been followed by the Soviet Union's continued domination of Albania, Bulgaria, Romania, Eastern Germany, Poland, and Hungary. Although Great Britain shared America's historical hostility toward European security commitments, Churchill observed that in this case "prevention is better than the cure" and that such an association

\footnotetext{
${ }^{3}$ NATO Office of Information and Press, "'How Did NATO Survive The Cold War?' NATO Video Lecture Transcript, March 11, 2004," http://www.Nato.Int/Multi/Video/Lectures/031104/V031 104al.htm.

${ }^{4}$ These force level estimates are drawn from analysis presented in Hastings Ismay, NATO: The First Five Years, 1949-1954 (Utrecht: Bosch-Utrecht, 1955) and Richard Kugler, Commitment to Purpose: How Alliance Partnership Won the Cold War (Santa Monica, CA: RAND Corporation, 1993).
} 
would "play its part in steadying and stabilizing the foundations of peace" as a compliment to the United Nations. ${ }^{5}$ Churchill sought an arrangement that would reverse America's ongoing withdrawal from Europe and ensure a robust American commitment to European security. However, American foreign policy leaders were reluctant to discuss a formal peacetime alliance with Great Britain or any other European state at that time.

Previous American leaders had remained faithful to the advice of the country's founding fathers and remained detached from European affairs. President George Washington had cautioned in his farewell address to "steer clear of permanent alliances with any portion of the foreign world," while Thomas Jefferson warned of "entangling and embroiling our affairs with those of Europe." 6 Over the next 150 years, the United States had consistently avoided unnecessary involvement in European affairs. Only one formal alliance with European powers had been executed, the Franco-American treaty ending in 1800. Even after World War II, the isolationist impulse remained strong, and demobilization was pursued with great vigor. Rather than accepting Churchill's advances, leading American policy makers sought to promote European self-sufficiency in defense matters through economic and military aid.

George F. Kennan, Jr. realized the importance of preventing the Soviet Union from controlling vast portions of Eastern and Central Europe, which served as the

${ }^{5}$ Don Cook, Forging The Alliance: NATO, 1945-1950 (London: Secker \& Warburg, 1989), 52-3.

${ }^{6}$ Yale University Libraries, "Farewell Address Of 1796," http://www.Yale.Edu/Lawweb/Avalon/ Washing.htm and University of Virginia Library, "The Writings of Thomas Jefferson, Volume 2," http://etext.lib.virginia.edu/etcbin/toccernew2? id=JefBv022.sgm\&images=images/modeng\&data=/texts/en glish/modeng/parsed $\&$ tag $=$ public $\&$ part $=1 \&$ division $=\operatorname{div} 1$ 
foundation for his strategy of containment. As deputy head of the U.S. mission in Moscow from May 1944 to April 1946, Kennan was in a unique position to observe and comment on American-Soviet relations. His containment strategy was justified in an 8,000-word telegram to U.S. Secretary of State James Byrnes near the end of his term and further developed in an anonymous 1947 article published in Foreign Affairs. ${ }^{7}$ Kennan argued, "The main element of any United States policy toward the Soviet Union must be a long-term, patient but firm and vigilant containment of Russian expansive tendencies...Soviet pressure against the free institutions of the Western world is something that can be constrained by the adroit and vigilant application of counter-force at a series of constantly shifting geographical and political points, corresponding to the shifts and maneuvers of Soviet policy." ${ }^{8}$ Kennan preferred for the United States to act as a balancing power, intervening to prevent Soviet hegemony while Western Europe recovered. He advised against arrangements that encouraged the division of Europe into Soviet and American spheres of influences, preferring to encourage the creation of a European balance of power that could contain the Soviet Union with only a limited military commitment on the part of the United States.

President Harry Truman put Kennan's containment strategy into practice with his proclamation of the Truman Doctrine calling for a dramatic increase in American aid to states opposing Soviet expansionism. The Greek government had been fighting communist guerilla forces since 1944, and with support from bases in neighboring

\footnotetext{
7 "X," “The Sources of Soviet Conduct," Foreign Affairs 25 (July, 1947): 566-582.

${ }^{8}$ Ibid, 575-6.
} 
communist states, the rebels posed a genuine threat to continued democracy in Greece. When Great Britain declared in March 1947 that it could no longer provide aid to Greece, President Truman recognized that the United States must fill this void. Yet, in his view, neither the United Nations nor any other single state could adequately fulfill this role. Truman therefore announced "it must be the policy of the United States to support free peoples who are resisting attempted subjugation by armed minorities or by outside pressures"9 and he requested $\$ 400$ million in supplemental funding for aid to both Greece and Turkey. The Truman Doctrine deepened the American commitment to European security and would soon be expanded into all of Europe through the European Recovery Plan (commonly known as the Marshall Plan).

U. S. Secretary of State George Marshall announced the European Recovery Plan during a speech at Harvard University in June 1947. It was increasingly clear to American leaders that many European states were on the verge of economic collapse and that they were too weak to provide for their own security. The Marshall Plan was therefore designed to promote European independence from, rather than increasing dependence on, the United States. Marshall Plan aid was to be distributed to the European states in accordance with their own reconstruction programs. Marshall emphasized, "This is the business of the Europeans. The initiative, I think, must come from Europe... The program should be a joint one, agreed to by a number, if not all,

\footnotetext{
${ }^{9}$ Fordham University, “Address Before A Joint Session Of Congress, March 12, 1947: The Truman Doctrine," http://www.Fordham.Edu/Halsall/Mod/1947TRUMAN.html.
} 
European nations." 10 He further stressed that American aid was "directed not against any country or doctrine but against hunger, poverty, desperation and chaos."II Economic assistance was offered to the Soviet Union and other countries behind the Iron Curtain, but Stalin refused to allow any of the governments under his influence to participate in a program he viewed as imperialistic. Western Europe benefited from the rebuilding of much of its economic infrastructure (particularly the iron-making and power industries) at a cost to the United States of more than $\$ 13$ billion over four years, equivalent to two percent of the United States' gross national product. ${ }^{12}$

Despite the promise of unprecedented levels of economic aid, some European leaders expressed concern for the future security of Western Europe after talks between the United States, Great Britain, France, and the Soviet Union broke down over the future of Germany in December 1947. British Foreign Secretary Ernest Bevin said "I am convinced that the Soviet Union will not deal with the West on any reasonable terms in the foreseeable future and that the salvation of the West depends upon the formation of some form of union, formal or informal in character, in Western Europe. Backed by the United States and the Dominions such a mobilization of moral and material force will inspire confidence and energy within, and respect elsewhere."13 In response, Secretary Marshall foreshadowed the events that would lead to the creation of the NATO alliance,

\footnotetext{
${ }^{10}$ Fordham University, "Speech At The Harvard University Commencement, June 5, 1947," http://www.fordham.edu/halsall/mod/1947marshallplan 1.html.

${ }^{11}$ Ibid.

${ }^{12}$ Dana Allin, "Debating Intervention," NATO Review no. 4 (Winter 2002): 4.

${ }^{13}$ Theodore Achilles, "The Omaha Milkman: The Role Of The United States In The Negotiations," in NATO's Anxious Birth, edited by Andre De Staerck. (New York: St. Martin's Press, 1985), 30.
} 
remarking that Europe should "come together for their own protection, see what they could do, and then turn to the United States, and see what we could do to make up the difference between what the situation required and what they were able to do by their own efforts."14

British leaders pressed for the organization of a collective defense regime among Western European states. Negotiations were given a sense of urgency by the fall of the Czechoslovakian government to Soviet-backed communists in February 1948. Czechoslovakia now joined the list of Soviet-sponsored governments holding power in much of Central and Eastern Europe. This coup increased the Soviet military threat by giving the Soviets access to the Czech arms industry, as well as ownership of the only European source of uranium. British efforts soon culminated in the signing of the Brussels Treaty in March 1948 by Belgium, France, Luxembourg, the Netherlands and Great Britain. This treaty established the Western European Union (WEU), which promoted greater integration of political, economic, and military activities in the pursuit of a common defense system. The Brussels Treaty was intended to last fifty years, during which the signatories agreed that if any of the allies should be the object of an "armed attack in Europe", the others would provide "all the military and other aid and assistance in their power." 15

The creation of the WEU and continued Soviet aggression finally forced the United States to become more active in European security affairs. The Soviets

\footnotetext{
${ }^{14}$ Charles Bohlen, The Transformation Of American Foreign Policy (New York: Norton Press, 1969), $92-$ 3.

${ }^{15}$ Western European Union, "Text of The Modified Brussels Treaty," http://www.Weu.Int/Treaty.htm.
} 
challenged Norwegian sovereignty in 1948 by compelling them to sign a mutual defense agreement similar to one that had been presented to Finland the previous year. Soviet forces began a blockade of Berlin the following month in response to the merging of the economic activities in the American and British occupation zones. American airpower was mobilized to conduct the Berlin airlift, which greatly increased the number of American forces stationed in Western Europe. It soon became clear to American leaders that many European countries were too divided and weak to withstand both domestic communist influences and Soviet military pressure.

\section{Establishing the North Atlantic Treaty}

President Truman accepted the necessity of an expanded American security role in Europe, declaring that the United States would "match the determination of the free peoples of Europe to protect themselves." ${ }^{\prime 6}$ Truman authorized negotiations with the Brussels Treaty powers for an expanded agreement that would also bind Canada, Denmark, Iceland, Italy, Norway and Portugal in a collective defense regime. Senator Arthur Vandenberg, in consultation with the U.S. State Department, crafted a resolution which recommended "the association of the United States by constitutional process, with such regional and other collective arrangements as are based on continuous and effective self-help and mutual aid, as affect its national security."17 In June 1948, the Vandenberg Resolution passed in the U.S. Senate with an overwhelming majority of senators voting in favor. This confirmed the extent of support for a change in America's foreign policy

\footnotetext{
${ }^{16}$ Gerard Mangone, A Short History of International Organization (New York: McGraw-Hill, Inc, 1954) 270.

${ }^{17}$ Avalon Project at Yale Law School, "Senate Resolution 239, Eightieth Congress, $2^{\text {nd }}$ Session, June, 11 , 1948," http://www.Yale.Edu/Lawweb/Avalon/Decade/Decad040.htm.
} 
that would make it possible for the United States to enter an Atlantic alliance. Formal negotiations began in December 1948 and an agreement was completed in April 1949, while the Berlin blockade was still under way.

The North Atlantic Treaty (also commonly referred to as the Washington Treaty) provided the framework for a new European security order while emphasizing the treaty's consistence with the UN charter. The treaty makes reference to Article 51 of the UN Charter which affirms the inherent right of independent states to individual or collective defense. ${ }^{18}$ The treaty commits each member country to sharing the risks as well as the benefits of collective defense. Member states are bound not to enter into any other international commitment that might conflict with the treaty. Negotiators drafted a treaty that fulfilled the needs of many Western European leaders, famously summarized by Lord Ismay as a desire to "keep the Americans in, the Russians out, and the Germans down." 19

The North Atlantic Treaty serves as a model of succinctness and flexibility. Unlike many other international treaties, it contains only fourteen short articles. These articles were written to provide overall regime guidance, while allowing the necessary restructuring to take place in response to changing circumstances The preamble and the first two articles of the treaty make it clear that the member countries believe that they belong to a community of nations within which cooperation should be developed not only

\footnotetext{
${ }^{18}$ Article 51 of the UN charter states "Nothing in the present Charter shall impair the inherent right of individual or collective self-defense if an armed attack occurs against a member of the United Nations, until the Security Council has taken measures necessary to maintain international peace and security."

${ }^{19}$ David Yost, NATO Transformed,The Alliance's New Roles in International Security (Washington D.C.: United States Institute of Peace Press, 1998), 52.
} 
for defense, but in other fields. Article One obligates the Alliance members to resolve disputes in a peaceful fashion, while Article Two encourages greater regional stability through increased communication. Article Two states "The Parties will contribute toward the further development of peaceful and friendly international relations by strengthening their free institutions, by bringing about a better understanding of the principles upon which these institutions are founded, and by promoting conditions of stability and wellbeing." 20 This flexibility inherent in Article Two has allowed the allies to consult on security developments anywhere in the world and to extend their cooperation into nonmilitary fields. More recently, this article has been cited as providing the authority for NATO's conduct of peacekeeping and peace enforcement operations.

Despite the obvious concerns over Soviet aggression at the time of the treaty's signature, there are no specific references to the Soviet Union and the treaty remains open to addressing any threats to member states. The Alliance's commitment to collective defense is emphasized in Article Three, which states, "The Parties, separately and jointly, by means of continuous and effective self-help and mutual aid, will maintain and develop their individual and collective capacity to resist armed attack." ${ }^{21}$ Should any member state feel threatened by a particular course of events, Article Four calls for the creation organizational structures to facilitate consultations. Article Five articulate the treaty's security guarantee that "an armed attack against one or more of them in Europe or North America shall be considered an attack against them all" and that they "will assist the

\footnotetext{
${ }^{20}$ NATO Office of Information and Press. "Text Of The North Atlantic Treaty, April 4, 1949". http://www.Nato.Int/Docu/Basictxt/Treaty.htm.

${ }^{21}$ Ibid.
} 
Party or Parties so attacked by taking forthwith, individually and in concert with the other

Parties, such action as it deems necessary, including the use of armed force, to restore and maintain the security of the North Atlantic area." 22 While this language enables the use of force in response to an attack, members are not obligated to respond forcefully under all circumstances. President Truman observed, "The Brussels Pact nations wanted the North Atlantic pact to state that, if a member was attacked, the other members would supply all the military and other aid and assistance in their power. This, of course, implied going to war...[this] was an obligation which, in view of our Constitution, we were not prepared to assume." 23 While Article Five underscores the collective defense activities that have historically dominated the Alliance, the presence of the other articles makes it clear that NATO's authority is not limited to threats to a member state's survival.

The remaining eight articles set some of the organizational rules for NATO. Included in these articles are the creation of the North Atlantic Council (NAC), and its authorization to organize subsidiary bodies as necessary. These articles also specify provisions for the addition of new members, the departure of existing members, and a review of the treaty after a period of ten years. According to Lord Hastings Ismay, the authors of the treaty, "did not attempt, at the outset, to draw up a blueprint of the international organization which should be set up, or to lay down any hard and fast rules

\footnotetext{
${ }^{22}$ Ibid.

${ }^{23}$ Harry Truman, Memoirs: Volume II: Years of Trial and Hope, (Garden City, NY: Doubleday \& Company, 1955), 249.
} 
of procedure. They realized that these could only be evolved step by step in the light of practical experience, and they proceeded accordingly. ${ }^{24}$

Any hopes that the mere pledge of mutual support would be sufficient to ensure the future security of Europe were short lived. During the signing ceremony for the North Atlantic Treaty, President Truman expressed hope that the security pledge alone would be sufficient to serve as "a shield against aggression and fear of aggression - a bulwark which will permit us to get on with the real business of government and society, the business of achieving a fuller and happier life for all its citizens."25 Similarly, Secretary of State Dean Acheson testified to Congress in 1949 that the North Atlantic Treaty would not commit the United States to send any soldiers back to Europe. However, the day after signing the NATO treaty, the Brussels Pact countries submitted a formal request for military and financial aid to the U.S. State Department. Similar requests were soon made by Denmark, Italy, and Norway as these states reassessed their security needs.

The ratification of the Washington Treaty in 1949 , followed shortly by the detonation of the Soviet Union's first nuclear device, created a favorable environment for further increases in American military aid to Western Europe. The 1949 Mutual Defense Assistance Act recognized that unless the military strength of Western Europe was greatly strengthened, these states were unlikely to be able to effectively oppose a Soviet invasion during any time in the next ten years. With the passage of the Mutual

\footnotetext{
${ }^{24}$ Ismay, NATO: The First Five Years, ix.

${ }^{25}$ Cook, Forging the Alliance, 54.
} 
Defense Assistance Plan, the United States provided more than a billion dollars in aid to Europe in the first year alone. American assessments of the Soviet threat were updated with the the release of National Security Council document number 68 (NSC-68) in 1950. This study concluded that the United States would have to dramatically increase both its nuclear capabilities and NATO's conventional forces in Europe in order to adequately deter the Soviet Union. Over the next several years, American and Canadian aid programs would provide nearly $\$ 30$ billion of assistance, with more than half of this allocated for military equipment. American defense spending increases were joined by greater spending among European allies. The aggregate of the defense budgets of all the NATO countries rose from $\$ 18.5$ billion in 1949 to $\$ 62.7$ billion in $1953 .{ }^{26}$ Larger, more capable forces were needed to serve as a credible deterrence to the Soviet Union and its Warsaw Pact allies and NATO governments pursued a combined strategy to enable their forces to work together toward this end.

NATO's first strategic concept document, entitled The Strategic Concept for the Defense of the North Atlantic Treaty Area, was approved in December 1949. The function of this document was to encourage greater cooperation and coordination between the military forces of member states. The defensive nature of the Alliance was emphasized throughout the strategy as well as the need for unity of effort among diverse military forces. Lord Ismay observed, "It became obvious that collective capacity to resist armed attack could not be effectively developed unless there were unity of command, unified planning and uniformity of military training, procedure and, as far as

\footnotetext{
${ }^{26}$ Defense spending estimates drawn from Ismay, NATO: The First Five Years.
} 
possible, equipment. And so it came about that by the end of 1950 , sovereign states were to entrust their forces to international commanders, assisted by international staffs., ${ }^{27}$ This strategy sought to oppose Soviet expansion in accordance with the political objective of containment. The 1949 Strategic Concept emphasized the deterrence role of NATO forces. The Secretary General emphasized, "Only if this mission was unsuccessful were these forces to be used against armed attack.,"28

Execution of the 1949 Strategic Concept led to a delegation of missions designed to take advantage of each Alliance members' relative strengths. For example, the strategic bombing mission was delegated to the United States while protection of sea lines of communication was assigned to the British. The continental European allies provided the majority of ground and air forces for territorial defense. It eventually became clear that the necessary manpower for these forces exceeded the capacity of the Europeans. American soldiers and airmen were deployed to Europe, with President Truman, Secretary Acheson, Secretary Marshall, and NATO’s first Supreme Allied Commander Europe General Eisenhower all publicly stating that these forces would come home once Europeans were able to put in place their own ground and air forces. ${ }^{29}$ Acceptance of West German Statehood and NATO Membership

While containment and deterrence continued to dominate the Alliance's relations with the Soviet Union, a more constructive relationship was sought with Germany in the

\footnotetext{
${ }^{27}$ Ibid, 161.

${ }^{28}$ Ibid, 189.

${ }^{29}$ Ernest May, "The American Commitment To Germany, 1949-1954," in American Historians And The Atlantic Alliance, ed. Lawrence Kaplan (Kent, OH: Kent State University Press, 1991), 68.
} 
early 1950s. Old animosities between Germans and other Europeans had to be overcome to allow a more unified opposition to Soviet expansion; many Europeans continued to fear the renewal of German nationalism, as expressed in the Dunkirk Treaty of 1947. This treaty governed British and French policies regarding the reconstruction of Germany and obliged each of the signatories to provide mutual assistance in the event of future German aggression. Despite their distrust of Germany, British diplomats soon began to recognize the need for German participation in the defense of Western Europe. In March 1948, British Foreign Minister Bevin advised Prime Minister Clement Atlee, "Instead of being bottled up in Central Europe, we feel the Germans have a great contribution to make to the world's industrial and social development. Our aim is to protect ourselves against any further aggression by Germany and at the same time to bring her back into the community of nations as a united entity on a democratic basis, with democracy as Western civilization understands it." ${ }^{30}$ Secretary of State Dulles shared these views, expressing an "intense concern for what he described as 'the suicidal strife' between France and Germany: . . . a 'firetrap' that had engulfed too many." ${ }^{, 31}$ NATO was seen as a vehicle for overcoming this historical division as well as providing a means for a more meaningful West German participation in the defense of Western Europe.

As the Federal Republic of Germany took shape in the aftermath of the Berlin Airlift, American leaders recognized the potential economic and military contributions that West Germany could make to the Alliance. A forward defense strategy, emphasizing

\footnotetext{
${ }^{30}$ Sean Kay, NATO And The Future Of European Security (Lanham, MD: Rowman \& Littlefield Publishers, 1998), 18.

${ }^{31}$ Ronald Preussen, John Foster Dulles: The Road To Power (New York: Free Press, 1982), 35.
} 
the opposition to Soviet forces as far to the east as possible, appeared to give the greatest hope for the successful defense of Western Europe. President Truman observed, "Without Germany the defense of Europe was a rearguard action on the shores of the Atlantic Ocean. With Germany there could be a defense in depth powerful enough to offer effective resistance to aggression from the East. Any map will show it, and a little arithmetic will prove what the addition of German manpower means to the strength of the joint defense of Europe." 32 During this period, the allies looked for ways to gain German participation in the defense of Western Europe while maintaining assurances that Germany would not pose a threat to its neighbors.

The solution proposed by French Premier Rene Pleven was the creation of an allEuropean army, through which France would exercise even greater oversight over German rearmament. Pleven outlined the creation of a European Defense Community (EDC), under which a European Assembly would appoint a European Minister of Defense to organize a combined military force funded by a common budget. These forces "would be placed at the disposal of the unified Atlantic force and would operate in accordance with the contractual obligations of the Atlantic Pact. ${ }^{, 33}$ Under this arrangement, Germany would contribute manpower but would not have its own General Staff, defense ministry, or armaments industry. American leaders approved of the EDC as a means of limiting German military ambitions, but they insisted that the primacy of NATO be maintained. The EDC treaty was signed in May 1952, after the allies rejected

\footnotetext{
32 Truman, Memoirs, 253.

${ }^{33}$ Leinden University, "History Of European Integration Site: The Pleven Plan," http://www.EuHistory.Leidenuniv.NI/Index.Php3?M=10\&C=51.
} 
Soviet Premier Joseph Stalin's offer to restart talks on German reunification.

Interestingly, while a number of European parliaments ratified the treaty, it was the French parliament that refused to ratify the treaty and led to its abandonment.

Following the rejection of the EDC, British Foreign Secretary Anthony Eden proposed the interim step of bringing West Germany and Italy into the WEU. As part of its acceptance into the WEU in October 1954, West Germany agreed not to manufacture advanced weapons systems such as warships or long-range bombers, except at the request of NATO. In a public declaration on October 23, 1954, the Government of the Federal Republic of West Germany agreed "never to have recourse to force to achieve the reunification of Germany or the modification of the present boundaries of the German Federal Republic, and to resolve by peaceful means any disputes which may arise between the Federal Republic and other states." ${ }^{34}$

French officials viewed NATO as an instrument of "double containment", directed at both Germany and the Soviet Union. While some member governments feared that West Germany's admission might aggravate tensions over Berlin and the question of eventual German reunification, the desire to increase NATO's ability to defend Western Europe overrode these fears. General Eisenhower concluded in his first annual report to the NAC, "Even with the maximum potential realized through collective efforts of member nations, there is little hope for the economical long-term attainment of security and stability in Europe unless Germany can be counted on the side of the free

\footnotetext{
${ }^{34}$ NATO Office of Information and Press, "Resolution of Association by Other Parties to the North Atlantic Treaty Adopted by the North Atlantic Council, October 22, 1954," http://www.nato.int/docu/ basictxt/b541022d.htm.
} 
nations. ${ }^{35}$ The key to overcoming the remaining trepidation regarding the resurrection of West German armed forces was the decision by the United States, Great Britain and Canada to maintain ground and air forces in Germany. The French ambassador to NATO was reportedly moved to tears by this decision, exclaiming "for fifty years, ever since 1905, French public opinion has waited for this announcement and at last we have it!"36 France at last concurred with the Federal Republic's entry into NATO and West Germany joined the Alliance in 1955.

\section{Increased Nonmilitary Cooperation}

NATO Secretary General Ismay was among the first to recognize "The military effort, urgent as that is, represents one of the means, but not all, to achieve that end [of security]...We touch here one of the profound reasons why so many of the peoples of the member countries show moderate interest in NATO. They are ready to accept the Atlantic alliance as a form of insurance policy against armed attack, but they are not yet prepared to recognize it as a means of achieving progress in more fruitful fields of human endeavor. It is up to the Council to correct this error." ${ }^{37}$ Ismay created a commission consisting of the Foreign Ministers of Norway, Italy, and Canada to make recommendations on greater NATO activity in non-military fields. The report by the Committee of Three recommended that NATO develop political organizations and increase the thoroughness of its political consultation. The Report of the Committee of

\footnotetext{
${ }^{35}$ NATO Office of Information and Press, SACEUR, First Annual Report (Brussels: NATO Office of Information and Press, 1951), 2.

${ }^{36}$ Edward Fursdon, The European Defense Community: A History (London: Macmillan Press, 1980), 321 2.

${ }^{37}$ Ismay, NATO: The First Five Years, 159.
} 
Non-Military Cooperation concluded that NATO members "should also be concerned with harmonizing their policies in relation to other areas, taking into account the broader interests of the whole international community; particularly in working through the United Nations and elsewhere for the maintenance of international peace and security and for the solution of the problems that now divide the world." ${ }^{38}$ In December 1956, the NAC accepted the committee's recommendations and agreed to increase the level of nonmilitary cooperation among its members. The new missions arising out of this period included efforts to limit drug trafficking, promote scientific cooperation, further economic cooperation, and address common environmental problems. While the political side of the Alliance grew somewhat stronger as a result of these efforts, collective defense remained the top priority for Alliance members and received the greatest amount of attention and funding.

During this same period, NATO leaders found it necessary to update the Alliance's military strategy. As a result of the burden placed on American forces with the outbreak of the Korean War, the Eisenhower administration initiated a "New Look" review aimed at complementing NATO's conventional posture with nuclear forces. Despite efforts to build larger military forces among the NATO allies and the deployment of substantial American forces to the continent, the Soviet Union and its Warsaw Pact maintained unquestioned conventional superiority over NATO forces throughout the 1950s. However, the Soviet nuclear arsenal was still in its infancy and the United States expected to maintain an advantage in nuclear forces for quite some time. NATO allies

\footnotetext{
${ }^{38}$ NATO Office of Information and Press, "The Report Of The Committee Of Three On Non-Military Cooperation In NATO,” http://www.Nato.Int/Docu/Basictxt/Bt-A3.htm.
} 
sought to overcome their inferiority in conventional forces by transitioning from a strategy of containment to that of "massive retaliation". This strategy would deter a Soviet attack by pledging that NATO would respond to aggression using every means at its disposal, even allowing for the first use of nuclear weapons.

Throughout the 1950s, world events were making the limitations of nuclear deterrence more apparent within the Alliance. The possession of nuclear weapons by the United States could not prevent the communist takeover of China, nor could it be effectively leveraged in other struggles against the expansion of communism. According to one historian, Eisenhower's reluctance to authorize air strikes against the Vietminh in defense of the French position at Dien Bien Phu "sealed the fate of EDC." 39 American nuclear superiority also failed to enable the United States or its allies to aid Hungary during its attempt to drive the Soviets out of their country in 1956. Rather than giving the United States greater leverage, the fear of escalation actually led President Eisenhower to reassure the Soviets of American disinterest. He asked his cabinet, "In view of the serious deterioration of their position in the satellites, might they not be tempted to resort to very extreme measures and even to precipitate global war?" ${ }^{\circ 0}$ Even with unchallenged American nuclear superiority, NATO was unable to adequately ensure European security. While NATO had embraced the concept of massive retaliation in 1957 through revisions to strategic guidance, increasing Soviet nuclear capability very quickly put the credibility

\footnotetext{
${ }^{39}$ Neill Nugent, The Government And Politics Of The European Political Community (Durham, NC: Duke University Press, 1989), 36.

${ }^{40}$ John Gaddis, We Now Know : Rethinking Cold War History (Oxford: Oxford University Press, 1997), 235.
} 
of this strategy in doubt and led to a debate on future Alliance strategy that was to last almost a decade.

These difficulties increased as improvements to the Soviet Union's offensive strike capabilities signaled that the United States was vulnerable to a Soviet nuclear attack resulting from any conflict originating in Europe. This vulnerability threatened to undermine the credibility of America's commitment to Europe along with the strategy of massive retaliation. Extended deterrence was also undermined by the Kennedy administration's promotion of a strategy of "flexible response," which would initially favor non-nuclear responses to international crises. As one historian observes, "Since the United States controlled nuclear decisions in NATO, reassurance had decreasing credibility for some European members." ${ }^{41}$ Changes to existing nuclear forces were proposed in an attempt to increase the credibility of extended deterrence.

In an effort to preserve its leadership role in the Alliance and restrict the proliferation of nuclear weapons in general, the United States sought to dissuade other European allies from developing their own nuclear inventories. Great Britain had obtained nuclear technology through their involvement in the Manhattan Project, resulting in their first successful nuclear test in 1952. The United States formally pledged to coordinate the development and operation of its nuclear forces with Great Britain in the 1958 Mutual Defense Agreement, but the United States remained unwilling to help its other European allies establish their own nuclear forces. One means of averting proliferation was to provide non-nuclear European allies with a greater voice in the

${ }^{41}$ Kay, NATO And The Future Of European Security, 42. 
control of nuclear weapons. One historian finds that "the nuclear sharing issue reflected the belief that joint management and even ownership would help build a community of shared interests and responsibilities among the allies, and would answer the demand for equality of status from states like West Germany." ${ }^{42}$ Under existing arrangements, any decision to use nuclear weapons would occur at the national level, ultimately residing with American or British leaders. Late in his second term, President Eisenhower initiated discussions for a Multi-Lateral Force (MLF). This force would consist of a fleet of five American Polaris missile submarines assigned to the NATO area with command and control shared among the United States and its NATO allies. Similarly, NATO commanders overseeing intermediate-range Jupiter missiles deployed to Turkey were delegated the authority to launch in the event of a nuclear attack on the United States. These proposals propped-up European confidence in extended deterrence, but were soon overshadowed by the efforts of France and other allies to develop their own nuclear forces.

President Kennedy viewed the nuclear control issue differently than his predecessor. Kennedy stated in 1959 , "We should face the fact that the fundamental purpose of the French atomic bomb is not to increase French capabilities but to increase its stature in the Alliance. The French bomb is aimed at Washington rather than Moscow. This is an odd way to run an alliance." 43 American submarines were delivered to NATO in 1963 as Eisenhower promised, but remained under American command. In addition to

\footnotetext{
${ }^{42}$ Mary Hampton, The Wilsonian Impulse: U.S. Foreign Policy, The Alliance, And German Unification (Westport, CT: Praeger Publishers), 55.

${ }^{43}$ Hampton, The Wilsonian Impulse, 81.
} 
reversing the delegation of authority approved by the Eisenhower administration, Kennedy proposed American control over all NATO nuclear forces. MLF collapsed under differences that would contribute to a challenge to Alliance unity. American officials convinced the West Germans to support their proposal for a combined force, but French leaders remained vigorously opposed. The MLF concept was abandoned in favor of the forward deployment of American tactical nuclear weapons as a signal to the Warsaw Pact that they might be used early in a conflict. The forward deployment of these nuclear forces in Europe was meant to reassure NATO allies that the United States intended to deter or, if need be, defeat the Soviets in the event of future aggression. This deployment failed to resolve existing disagreements and contributed to French and German doubts regarding the future utility of the Alliance.

Transatlantic relations were also strained by the Suez Canal crisis in 1956. Egyptian President Nassar nationalized the Suez Canal in 1956, which had gained increased significance to the region as Middle Eastern oil exports grew. France and Great Britain used the pretext of a peacekeeping mission following Israel's invasion of Egypt to gain control of the Canal Zone and remove Nassar from power. American leaders, offended by the lack of consultation by its allies and concerned about the risk of Soviet involvement on the side of the Egyptians, forced France and Great Britain to withdraw and accept the deployment of a multinational peacekeeping force. The incident served as a reminder of the balance of power within the Alliance and the leverage that American leaders exercised over other NATO member states. The United States sought to enforce the norms of the regime, particularly those calling for consultation among the allies prior to taking action in areas where members share interest. French leaders 
became particularly disillusioned with their subordinate status and accelerated their efforts to develop a defense capability free from American influence.

When Charles de Gaulle returned to power in 1958, he proposed a reorganization of the NAC to increase French influence within NATO. This reorganization would recognize the United States, Great Britain, and France as the leaders of the Alliance and authorize these three states to form a combined command structure to oversee all military forces deployed in Europe. When this tripartite structure was rejected by American and British leaders, De Gaulle continued to express his dissatisfaction with many organizational aspects of NATO and began to decrease participation in and funding for common programs. Under De Gaulle's leadership, France was able to continue to benefit from NATO's efforts while steering resources toward the pursuit of its own national interests. France took advantage of the security situation in Europe to become a freerider and retain benefits of transatlantic cooperation with only a minimal investment in the organization.

De Gaulle accelerated efforts to establish a French nuclear force and to strive for greater French self-sufficiency in defense of its homeland and extraterritorial interests. One historian attributes his actions to a "belief that nuclear weapons could be used only in defense of one's own national territory and that American engagement in Europe would inevitably weaken with time." 44 De Gaulle viewed Europe as a "Europe of Nation States" and felt that state interests were clearly dominant to those of international organizations. He was dismissive of claims that the future security of France could be

\footnotetext{
${ }^{44}$ Gregory Flynn, French NATO Policy: The Next Five Years (Washington, D.C.: RAND, 1989), 3.
} 
guaranteed by outside powers and pursued reforms that slowed the pace of European integration. Former U.S. Secretary of State Dean Acheson characterized de Gaulle's policies as "a historically backward step that would reintroduce the disease of nationalism whose symptoms had been suppressed at such great cost and effort." ${ }^{.5}$ De Gaulle rejected this claim, stating in a 1959 press conference, "I believe that the Alliance will be all the more vital and strong as the great powers unite on the basis of cooperation in which each carries his own load, rather than on the basis of an integration in which peoples and governments find themselves more or less deprived of their roles and responsibilities in the domain of their own defense." ${ }^{46}$ French representatives refused to sign NATO strategy document MC 14/3, which formally adopted Flexible Response. De Gaulle's dissatisfaction with France's role in NATO led to tensions between the United States and France and France's eventual withdrawal from NATO's integrated military structure.

American forces were first ordered out of France in 1959 when de Gaulle chose to ban all foreign troops and nuclear weapons from French soil. As most of these weapons were under the control of United States Air Forces Europe (USAFE), several American squadrons were transferred from France to bases in Great Britain and West Germany. On March 7, 1967, de Gaulle emphasized his desire to regain "full sovereignty [over] French territory" and stated that his government would "no longer accept the presence of foreign units, installations, or bases in France falling in any respect under the control of

\footnotetext{
${ }^{45}$ Hampton, The Wilsonian Impulse, 77.

${ }^{46}$ Edgar Furniss, "De Gualle's France and NATO: An Interpretation," International Organization 15, no. 2 (Summer 1961): 358.
} 
authorities other than French authorities." ${ }^{47}$ Later that month, NATO initiated operation FRELOC (Fast Relocation) and withdrew from numerous military installations around the country. Although France's wish to distance itself from NATO caused considerable consternation, the manner in which this occurred demonstrated the allies' mutual respect for each other. The peaceful nature of this process stood in stark contrast to the violent crackdown by Soviet troops when Hungary attempted to withdraw from the Warsaw Pact in 1956.

The removal of NATO units from France created a number of hardships for the Alliance. In Paris, NATO headquarters had been located only minutes away from Supreme Headquarters Allied Powers Europe (SHAPE) headquarters and United States European Command (EUCOM) headquarters, which fostered a close working relationship among these organizations. After the move, NATO headquarters was relocated to Brussels, Belgium while SHAPE headquarters went to Mons, Belgium and EUCOM headquarters to Stuttgart, Germany. Rather than being only minutes apart, SHAPE and EUCOM were now separated from NATO headquarters by approximately 50 miles and 265 miles respectively. In addition to the time and expense of relocating command, control, and computer facilities, the loss of guaranteed access to France's air defense system and to French segments of NATO's communications network threatened the Alliance's ability to coordinate operations in the event of an attack. France pledged to cooperate with NATO on most issues, but would not attend meetings of NATO's Military Committee, its Defense Planning Committee, or participate in combined

\footnotetext{
${ }^{47}$ Kenneth Hunt, NATO Without France: The Military Implications (London: Institute For Strategic Studies, 1966), 12-16.
} 
exercises. British leaders joined American critics of France's actions, concluding, “President de Gaulle's policy of 'cooperation not coordination' is unfortunately the recipe for military disaster. His idea of a renascent Europe, based on a series of proud and strong national armies has the musty smell of obsolescence." ${ }^{48}$ As NATO reorganized its operations in the aftermath of the FRELOC deployment there was once again recognition that the Alliance must adapt to new strategic realities or face irrelevance.

\section{Balancing Defense and Détente}

The failure of the MLF, combined with the influence of de Gaulle's rhetoric and NATO's inaction over the erection of the Berlin Wall also led West German leaders to question the primacy of NATO in its foreign policy. Germany's allies seemed increasingly less interested in pursuing reunification, which continued to be a core goal of German foreign policy. President Kennedy called it "silly" to discuss the possibility of risking nuclear war over Berlin, stating that "all of us know that Germany will probably never be reunited. ${ }^{, 49}$ Brandt now sought to open up a dialogue with the East, which held a greater promise of ensuring West German security while increasing the potential for eventually achieving German reunification. The pressure for changes within the Alliance was now becoming too great for NATO leaders to ignore.

In light of these increasingly conflicting views, NATO member states once again reassessed their approach to security. The Harmel review was an attempt to renew the

\footnotetext{
${ }^{48}$ Alistair Buchan, NATO In The 1960s: The Implications Of Interdependence (New York: Praeger Press, 1960), 43.

${ }^{49}$ Hampton, The Wilsonian Impulse, 72.
} 
solidarity within the NATO Alliance by conducting an in-depth review of the Alliance's aims. The process was initiated in 1966 by Belgian Foreign Minister Pierre Harmel, who was tasked to identify ways of strengthening the Alliance by identifying appropriate tasks and specifying the procedures for their fulfillment. According to Leon Sloss, a participant in the Harmel review, "The most important objectives of the Harmel report were to restore a sense of solidarity and purpose in the Alliance, and to gain public support for the Alliance at a time when people began to question whether a military alliance still was required. ${ }^{, 50}$ The Harmel report found that détente and defense were equally important and compatible aspects of NATO policy. The report concluded, "Military security and a policy of détente are not contradictory but complementary. Collective defense is a stabilizing factor in world politics. It is the necessary condition for effective policies directed towards a greater relaxation of tensions. The way to peace and stability rests in particular on the use of the Alliance constructively in the interests of détente." ${ }^{51}$ The Harmel report called for the creation of specialized groups to seek a greater consensus on security issues by balancing objectives associated with both defense and détente.

Alliance strategy was influenced by a general acceptance of the principle of Mutually Assured Destruction (MAD). By the late 1960s, it had become clear that both the United States and the Soviet Union had sufficient nuclear forces to retaliate with devastating force in the event of a first strike by either side. One historian characterizes

\footnotetext{
${ }^{50}$ Ibid, 111.

${ }^{51}$ NATO Office of Information and Press, "The Future Tasks Of The Alliance - The Harmel Report," http://www.Nato.Int/Docu/Basictxt/B671213a.htm.
} 
the European allies as facing a dilemma where "on one hand there is apprehension that the United States would not provide the necessary protection, while on the other, there is a real fear of the consequences of a nuclear exchange." 52 Another finds the preference for détente over defense among some Europeans to be indicative of a belief that "they knew better how to deal with the Soviets: through engagement and seduction, through commercial and political ties, through patience and forebearance. ${ }^{, 53}$ NATO's previous strategy based on defense through deterrence needed to be complemented by an effort to create a greater dialogue and thereby reduce the risk division within the Alliance.

The Harmel report, titled "Future Tasks of the Alliance," was formally endorsed by the allies in 1967, resolving differences that had emerged within NATO over the risks and benefits of engagement. While the United States favored maintaining a strong posture of deterrence, the report recognized the value of proposed efforts to promote a reduction in East-West tensions through various political and economic initiatives. The report called for NATO to "assure the balance of forces, thereby creating a climate of stability, security and confidence" that will allow the allies "to pursue the search for progress towards a more stable relationship in which the underlying political issues can be solved." ${ }^{54}$ In addition to the task of deterring Soviet aggression, NATO leaders agreed to coordinate their efforts towards German reunification and arms control and to continue to seek to diffuse tensions through transparency and confidence-building activities.

\footnotetext{
${ }^{52}$ Thomas Schwartz, America's Germany: John J. McCloy and the Federal Republic of Germany (Cambridge: Harvard University Press, 1991), 3.

${ }^{53}$ Robert Kagan, Of Paradise and Power: America and Europe in the New World Order (New York: Alfred A. Knopf, 2003), 28.

${ }^{54}$ NATO Office of Information and Press, "The Future Tasks Of The Alliance."
} 
The acceptance of the Harmel report was shortly followed by the announcement of Chancellor Brandt's Ostpolitik initiative and an acceleration of arms control efforts. The Harmel report acknowledged "no final and stable settlement in Europe is possible without a solution of the German question which lies at the heart of present tensions in Europe. Any such settlement must end the unnatural barriers between Eastern and Western Europe, which are most clearly and cruelly manifested in the division of Germany. Between 1969 and 1972, Brandt negotiated an unprecedented number of agreements with the Soviet Union and the East bloc, including the 1972 Basic Agreement between West and East Germany. National Security Advisor Henry Kissinger would later say of these efforts, "I do not believe in divisible détente in the sense that one side does the defense and the other side does the negotiating ... that Europe should have a monopoly on détente and America on defense" ${ }^{\$ 55}$ For his part, Kissinger oversaw negotiations on the Anti-Ballistic Missile (ABM) and Strategic Arms Limitations Talks (SALT) treaties that sought to ensure a balance of nuclear forces and create a climate of stability for future negotiations.

Despite the allies' general support for détente, there were countless differences among the allies regarding its implementation. Distrust of Ostpolitik was expressed by British and French leaders who concurred with Kissinger's view that "the new German government informed rather than consulted. They reported progress; they did not solicit advice." ${ }^{56}$ Similarly, American arms negotiations with the Soviets were complicated by

\footnotetext{
${ }^{55}$ Hampton, The Wilsonian Impulse, 139.

${ }^{56}$ Henry Kissinger, White House Years (Boston: Little, Brown, 1979), 530.
} 
demands from allies that West European interests must be taken into account. Americans and Europeans found themselves disagreeing on important events such as the conduct of the Yom Kippur War of 1973 and devaluation of the dollar. One historian notes a widening view of security during this period as "the United States pursued a global policy while the Europeans concentrated on regional issues." ${ }^{57}$ Disillusionment with détente became more significant in the United States as more Americans became convinced that arms control provided more benefits to the Soviets than to themselves. A backlash began to form against détente within the United States, while Europeans remained committed to its continued practice.

\section{NATO's Dual-Track Strategy}

The competing norms of deterrence and détente divided the allies as they debated the appropriate response to an improvement in Soviet nuclear forces in the mid-1970s. In 1977, the Soviets began replacing obsolete nuclear missiles with the mobile, mediumrange SS-20 missiles. These new weapons could not reach the United States, but posed an increased threat to Western European allies due to their ability to carry multiple warheads and to be launched within minutes. In December 1979, NATO responded with a "dual-track" strategy balancing the two practices of détente and deterrence by agreeing to modernize nuclear weapons systems in Europe while simultaneously pursuing arms control agreements with the Soviet Union. American Pershing II and cruise missiles would be deployed in Europe while the United States led negotiations aimed at limiting intermediate-range nuclear weapons on both sides. Three weeks after the dual-track

\footnotetext{
${ }^{57}$ Lawrence Kaplan, American Historians And The Atlantic Alliance. (Kent, OH: Kent State University Press, 1991$), 7$.
} 
decision, the Soviets invaded Afghanistan, leading President Carter to characterize this period as "a threat to world peace greater than any since 1945." ${ }^{, 58}$ In the face of these challenges, NATO clung to a strategy that favored unity over fragmentation and chaos.

Despite difficulties in the transatlantic relationship, NATO allies once again demonstrated that they were willing to accept the domestic political and economic costs of pursuing a common strategy. The deployment of American intermediate-range nuclear missiles was extraordinarily controversial within many member states. In the words of one historian, the public demonstrations in Germany, the Netherlands, and Great Britain "seemed capable of overthrowing not only individual governments but NATO itself." When the first Pershing II missile system became operational in 1983, the Soviets tried to force the Alliance to choose between collective defense and détente by suspending all arms-control negotiations until the new weapons were withdrawn. The ability of the allies to withstand both internal and external pressure eventually brought the Soviets back to the negotiating table and vindicated the dual-track strategy.

During a series of summit meetings in 1986, President Reagan and General Secretary Gorbachev discussed the removal of all nuclear weapons from Europe. Despite a revival of concerns that any change to the status quo would undermine the credibility of the United States' commitment to European security, American leaders succeeded in negotiating the removal of all intermediate nuclear missiles from Europe the next year. The Intermediate Nuclear Forces (INF) Treaty became the forerunner to a series of arms

\footnotetext{
${ }^{58}$ Gaddis, We Now Know, 126.

${ }^{59}$ Gerard Smith, "The SS-20 Challenge And Opportunity: The Dual-Track Decision And Its Consequences, 1977-1983," in American Historians and The Atlantic Alliance, ed. Lawrence Kaplan (Kent, OH: Kent State University Press, 1991), 130.
} 
control agreements and a general thawing of East-West relations. As one historian observes, "The INF treaty could have signaled the termination of the Alliance. Its goals were either realized or well on the way to realization." treaty would be shortly followed by the fall of the Berlin Wall in November 1989 and the end of communist rule in several Eastern European states. As NATO member states recognized that they were on the verge of winning the Cold War, they once again found the need to adapt the Alliance's strategy and organizations to a new set of challenges. European Integration during the Cold War

While NATO evolved to become the primary forum for transatlantic coordination on matters of collective defense and military force planning, a separate set of regimes were taking root within Europe to enhance cooperation on economic and social policies. Jean Monnet, an influential French politician, is commonly viewed as the driving force behind European integration. Monnet recognized as early as 1943, "The countries of Europe are too small to give their peoples the prosperity that is now attainable and therefore necessary....To enjoy the prosperity and social progress that are essential, the States of Europe must form a federation or a 'European entity' which will make them a single economic unit." ${ }^{, 61}$ Although related proposals for the creation of a European Defense Community were unable to garner sufficient public support in the immediate aftermath of World War two, a number of steps were taken to promote closer economic ties. In 1951 France, Germany, Italy, Belgium, Luxembourg and the Netherlands signed

\footnotetext{
${ }^{60}$ Kaplan, American Historians and The Atlantic Alliance, 8-9.

${ }^{61}$ Jean Monnet, Memoirs (Garden City, NY: Doubleday, 1978), 222.
} 
the Treaty of Paris establishing the European Coal and Steel Community (ECSC). The ECSC was formed to regulate the production of coal and steel among its members. These resources were identified due to their significance as the foundation of modern military power. The ECSC was intended to do more than assure the efficient distribution of economic commodities. According to Robert Schuman, the German-born Foreign Minister of France and one of the drafters of the treaty, the ECSC was intended to make war between its members "not just unthinkable but materially impossible."62

The 1957 Treaty of Rome broadened the scope of economic cooperation among member states to more sectors of the economy. The ECSC was joined by the European Economic Community (EEC) and the European Atomic Energy Community (EURATOM). The EEC was charged with reducing protectionism and working towards the goal of establishing a common market within twelve years. EURATOM coordinated nuclear energy programs among member states. The Treaty of Rome enumerated four policy areas that would bring the common market into practice. These "four freedoms" included the free movement of people, goods, services, and capital among the borders of member states. Reducing the significance of national borders was identified as a key part of the strategy to eventually bring about a united Europe with strong supranational institutions overseeing interstate relations. The three communities had the same membership and shared a Court of Justice and Parliament, while maintaining separate Councils and Commissions.

\footnotetext{
${ }^{62}$ European Union Office of External Relations, "Declaration of 9 May 1950," http://europa.eu.int/abc/ symbols/9-may/decl_en.htm
} 
The quest for greater economic integration proceeded in an uneven fashion over the next two decades. The process of integration was later described by former European Commission President Jacques Delors as "a cycle in which years of stagnation are followed by swift advances which in turn lead to crisis and back to stagnation. ${ }^{, 63}$ While France had historically led the drive toward integration, even French leaders felt the process proceeded too quickly at times. An agreement to transition away from decisionmaking through concensus to a process of majority-voting in the Council was opposed by President de Gaulle. France withdrew from the Council of Ministers for six months until a compromise was reached allowing member states to veto proposals on matters of "national importance". The Merger Treaty of July 1967 brought the various Councils and Commissions of the three communities into into a single European Council of Ministers and European Commission.

The European Community (EC) both deepened and widened during the 1970s and 1980s. The cooperation among EC member states resulted in a more than six hundred percent increase in internal trade from 1958 to 1970, compared to a trade increase of only seventy percent between Europe and rest of the world. ${ }^{64}$ The membership of the EC expanded to include Great Britain, Denmark and Ireland following Predident de Gaulle's retirement from politics. The EC Despite renewed French desires to eventually establish a European security regime separate from NATO, other member states shared little interest. EC member states pledged to consult with one another on major international

\footnotetext{
${ }^{63}$ Yves Boyer and Burkard Schmidt, "Should and Can Europe Bridge the Capabilities Gap?" NATO Review' 50, no. 3 (Fall 2002): 14.

${ }^{64}$ Philip Thody, An Historical Introduction to the European Union (London and New York: Routledge, 1997), 19.
} 
problems, but were unwilling to establish formal organizational structures that might rival those of NATO. When French President Mitterrand suggested the revitalization of the WEU during the 1984 Fontainebleau Summit, British leaders expressed reservations that such an effort would represent a challenge to the unity of NATO. ${ }^{65}$ The highest priority for most EC members was the creation of a single European market. The 1986 Single European Act brought the objectives of the Treaty of Rome closer by providing specific provision for the free exchange of goods and services within the community. The authority of the EC was expanded to address additional aspects of environmental and immigration policies. The Single European Act also introduced the concept of European Political Cooperation, which would allow for closer consultation on defense and security issues in accordance with French desires. By the end of the decade, European integration had sufficiently progressed to make EC member states more prepared to deal with the Germany's reunification along with the other economic, political, and military challenges that would accompany the end of the Cold War.

Regime Analysis: NATO During the Cold War

A power-based approach to regime analysis is consistent with the formation of NATO as a collective defense regime and accounts for many of the changes within the Alliance during the Cold War. Realists credit the looming Soviet threat to the global balance of power as the primary factor in the creation of a collective defense regime. NATO was formed to compliment existing European efforts to cooperate in the defense of Western Europe from Soviet aggression. NATO satisfied European security concerns

\footnotetext{
${ }^{65}$ Michael Clarke, "Britain," in Brenner, Michael, ed. NATO and Collective Security (New York: St. Martin's Press, 1998), 7.
} 
by linking the interests of the United States to Europe while contributing to an American strategy of containment. Collective defense reduced the risk of a potential resurgence of a threat from either the Soviet Union or Germany while providing a means for the United States to contribute to the economic and military recovery of Europe following the Second World War. NATO's defining characteristic was the involvement of the United States, which avoided the devastation of six years of war on the continent and emerged as the dominant economic and military power. NATO was created as a vehicle for American aid to Western Europe, with the United States bearing much of the cost of European defense.

The preservation of American hegemony was a primary objective of post-War United States foreign policy and was accepted by its NATO allies as a means of ensuring their own security. The presence of a strong United States in Europe prevented the emergence of competing security structures that could divide European states into factions that develop their own security dilemmas or could more easily be brought under Soviet influence. With the imminent threat of Soviet aggression as their foremost security concern, European states were less concerned with the potential future consequences of encouraging American hegemony than they were with ensuring their survival in the near term. The United States developed close security ties with the states of Western Europe that discouraged the creation of competing security regimes among these states.

The expectation among the allies that continental Europe would serve as the site for a future confrontation with the Soviet Union drove force structure considerations on both sides of the Atlantic. In order to prepare for large scale conventional wars in Europe 
or elsewhere, the American military emphasized mobility, along with the capacity to project and sustain forces over distance and time. American force planning guidance called for less dependence on large conventional armies while increasing the need for agile military forces and improved intelligence assets. In contrast, European members of NATO had historically structured their militaries around an expectation that their military forces would most likely be utilized to defend Western Europe against Soviet aggression implied that the battle would occur on or near their own territory. The demands placed on these militaries during the Cold War called for the maintenance of large conscript armies capable of fielding heavy armor formations supported by tactical airpower. These forces were organized for territorial defense, a role that failed to emphasize the need to project forces over great distances, or to sustain them far outside of their borders for long periods. The organization of Allied force structures along different models suited the practice of collective defense within Europe, while reinforcing the hegemonic role of the United States within the Alliance.

As the Alliance hegemon, military capabilities of the United States greatly exceeded those of its allies and gave American leaders a large voice in determining Allied strategy. The United States maintained a dominant role in the Alliance, but at the cost of developing and deploying much more extensive nuclear and conventional military forces than those of its NATO allies. American nuclear deterrence a cornerstone of collective defense efforts, and the presence of American troops enabled the credible practice of extended deterrence. Periods of indecision and inaction on the part of the Alliance can be associated with an absence of American leadership while many of the initiatives embodying regime changes were sponsored by American leaders. Changes in 
strategic paradigms from the concept of "massive retaliation" to "flexible response" and the practice of détente consistently reflected American preferences and capabilities. The European allies' continued dependence on the United States to assure the security of the continent gave American leaders political leverage that extended even to events outside of Europe. The outcome of the 1956 Suez Canal Crisis is one example of the influence of the United States over even the most capable and determined members of the Alliance. The United States continued to successfully provide policy leadership within NATO even when its proposals had strong domestic consequences for its European allies, as many NATO governments experienced during the debate over NATO's dual track strategy. From an organizational perspective, NATO made a number of important contributions to transatlantic security during the Cold War, even if it did not substantially alter the hegemonic status of the United States. In their defense of neoliberal institutionalism entitled "The Promise of Institutionalist Theory," Keohane and Martin "do not argue that NATO could have maintained stability under any imaginable condition ... what we argue is that institutions make a significant difference in conjunction with power realities." ${ }^{, 66}$ NATO successfully contributed to the defense of North America and Western Europe because member states recognized their interdependence and developed ways of cooperating to achieve their common security objectives. By operating within NATO, states gained access to additional assets as well as better information on the potential behavior of its allies. Increased information and transparency among allies reduced uncertainty and led to better decision-making. Keohane and Martin view NATO

\footnotetext{
${ }^{66}$ Robert Koehane and Lisa Martin, "The Promise of Institutionalist Theory," International Security 20, no. 1 (Summer 1995): 42.
} 
as an important venue for overcoming policy differences between members during the Cold War because Allied rules and procedures promoted conditions of reciprocity and transparency. This resulted in an environment conducive to eliminating the need for relative gains among member states.

NATO developed numerous internal organizations created to coordinate the military preparations necessary to ensure the defense of Europe, while the EC contributed to European security by promoting economic integration. NATO organizational bodies generally promoted the United States' involvement in European security rather than acting as a constraint on American power. These bodies focused on coordinating defense preparations within Europe, to include common military strategy, force planning, logistical support, and the development of common equipment and doctrine. A command structure, led by the senior American general officer in Europe, was specified as a means of ensuring unity of command for NATO forces. NATO committees often based their guidance on existing United States practices in such issue areas as air defense, nuclear planning, and communications planning.

Organization changes resulted from occasions when member states questioned the ability of NATO's norms, rules, and procedures to meet existing challenges. NATO leaders introduced countless reforms to improve relations among member states as well as the Alliance's capability to achieve shared objectives. NATO's internal organizations and procedures helped Alliance members overcome their differences and achieve a consensus regarding collective action. The credible practice of nuclear deterrence served as the center of this debate in the 1960s and 1970s, and further organizational reforms would be anticipated with the end of the Cold War. 
The concepts of a collective identity and shared values emphasized in a normbased approach to regime analysis are also quite relevant to the formation and evolution of NATO during the Cold War. A common fear of Soviet expansion provided the catalyst for the formation of an international security regime, with NATO representing the acknowledgment that America and Europe shared a common identity and that their future prosperity and security was linked. Haglund views NATO during the Cold War as an embodiment of the collective identity of "the West", an imagined community constructed by the perception of a threat to its shared culture by the Soviet Union and the communist states in the east. ${ }^{67}$ In contrast to realist depictions of NATO as a product of American hegemony, a norm-based approach to regime analysis suggest that the nature of the European, Soviet and American governments influenced regime formation in NATO more than material factors.

A norm-based approach to regime analysis characterizes transatlantic relations during the Cold War as the emergence of a security community among democratic states. Weber asserts that NATO represents just such a community during this period. ${ }^{68} \mathrm{He}$ suggests that a security community can be institutionalized through the acceptance of norms of equality, unanimous decision-making and by efforts to enhance transparency and facilitate the transfer of information among states. Eden similarly observes, "Insofar as the Atlantic community has a collective identity, it is expressed largely through the

\footnotetext{
${ }^{67}$ David Haglund, "Community of Fate or Marriage of Convenience? ESDP and the Future of Transatlantic Identity," in NATO and European Security: Alliance Politics from the End of the Cold War to the Age of Terrorism, eds. Alexander Moens, Lenard Cohen and Allen Sens (Westport, CT: Praeger, 2003), 1-18.

${ }^{68}$ Stephen Weber, "Does NATO Have a Future?" in The Future of European Security, ed. Beverly Crawford. (Berkeley, CA: University of California: 1992), 360-95.
} 
institutions of NATO." ${ }^{69}$ NATO members came to the Alliance with a liberal, democratic identity which distinguished them from other non-democratic states. These states were part of a voluntary transatlantic community in which all members felt they had a stake in each other's security.

Risse-Kappen focuses on NATO as he examines how the norms that govern international regimes reflect the collective identity of their members. ${ }^{70}$ The recent proliferation of regimes has accompanied the rise of liberal democratic governments. International cooperation is more common among liberal states that share a common understanding of concepts such as "order" and "justice". He observes that democracies perceive each other as peaceful because of the norms that guide their domestic politics and they form international organizations to promote and defend their common values. He argues that democratic states are able to make stronger commitments to international regimes due to the nature of their liberal democratic structures and their normative characteristics. NATO membership bolstered the national security interests and defense practices of member states "who practice regular consultation, consensus-building and equal participation in the decision-making process."71

A common commitment to norms of consultation and compromise deepened the ties among member states and contributed to their perception of NATO as a democratic

${ }^{69}$ Douglas Eden, Europe and the Atlantic Relationship: Issues of Identity, Security and Power (New York: Palgrave Macmillan, 2000), 2.

${ }^{70}$ Risse-Kappen, Thomas, "Collective Identity in a Democratic Community: The Case of NATO" in The Culture of National Security: Norms and Identity in World Politics, ed. Peter Katzenstein (New York:

Columbia University Press, 1996), 357-399.

${ }^{71}$ Risse-Kappen, "Collective Identity in a Democratic Community," 369. 
community. Democratic governance promotes norms establishing the equality of citizens, majority rule, and the preference for compromise over violent confrontation. These norms were reflected in the Alliance's political and military structures. Since no collective action can be taken over the objection of any member, NATO members sought common positions out of necessity. The allies frequently consulted each other and were able to achieve some manner of international legitimacy before taking action. NATO's evolution during the Cold War was guided by a commitment to multilateralism bringing together sovereign states of different capabilities, but shared values.

The norms and rules of NATO exerted an effect on the behavior of member states, even if collective decisions did not always reflect national preferences. In the first few decades of its existence, a sense of community influenced the process through which member states formed their interests. NATO 's collective identity reinforced the commitment of member states to the regime and allowed its members to overcome frequent crises and changes in the international system. The allies were held together by "a mutual understanding that the Soviet threat was the central geopolitical challenge of the time, Europe was the primary terrain on which that threat had to be confronted, and West Europeans were the primary allies of the United States." ${ }^{, 72}$ Sustaining this sense of community would be but one of many challenges facing the Alliance in the aftermath of the Cold War.

\footnotetext{
${ }^{72}$ Philip Gordon and Jeremy Shapiro, Allies at War: America, Europe and the Crisis in Iraq (New York:McGraw-Hill, 2004), 20.
} 


\section{Conclusion}

The three approaches to regime analysis provide a number of insights into the creation and evolution of NATO during the Cold War. The formation of NATO was consistent with the interests of the United States by aiding the practice of containment against the Soviet Union and serving as a means of promoting American hegemony within Europe. The United States bore much of the responsibility for the defense of Western Europe and the presence of a benevolent hegemon allowed European states to pursue greater economic integration that provided further benefits to the region. Emerging collective security functions allowed for the reintegration of Germany into Western Europe and "prevented the development of security dilemmas among the allies by using the institutional mechanisms of the Alliance to promote transparency, cooperation, and collective action." ${ }^{, 3}$ Occasional crises occurred among the allies, but the effects of these crises were tempered by a sense of community based on shared values and compliance with accepted norms. A commitment to collective defense was maintained throughout this era and a pattern of cooperation was established that would enable the Alliance to readily adapt to future changes in the international security environment.

\footnotetext{
${ }^{73}$ Tom Lansford, A Bitter Harvest: U.S. Foreign Policy and Afghanistan (Burlington, VT: Ashgate, 2003), 179-180.
} 
"At NATO, transformation is nothing new. But it is fair to say that changes during NATO's first 40 years were relatively gradual and comparatively small. Changes over the past 16 years, however, have been much more sudden and far-reaching."

- NATO Secretary General, Jaap de Hoop Scheffer (2005)

\section{Chapter 3: Post-Cold War NATO}

The 1990s were a period of rapid and far-reaching changes in the internal relations between member states and in the relationship of NATO with the rest of the international community. This period of change would be characterized by great uncertainties regarding the nature of the emerging threat and the best ways to prepare the Alliance to face future challenges. During the Cold War, member states overlooked many lesser threats as they focused on countering the capabilities of the Soviet Union and Warsaw Pact states. Numerous secondary threats persisted, and were in many ways magnified in the post-Cold War era. The risk of civil wars in Europe, nuclear weapons proliferation, and transnational terrorism all increased as Soviet influence declined and a security vacuum formed. As British Prime Minister Margaret Thatcher later observed, "The Europe that has emerged from behind the Iron Curtain has many of the features of the Europes of 1914 and 1939: ethnic strife, contested borders, political extremism, nationalist passions and economic backwardness."

The typology of approaches to regime analysis utilized throughout this study provide a useful means of examining the process of regime change within NATO during this era. The United States viewed NATO as a means of influencing the changing security environment in Europe and serve as a stabilizing force during this period of

\footnotetext{
${ }^{1}$ Margaret Thatcher, The Downing Street Years (New York: Harper Collins, 1993), 813.
} 
uncertainty. Despite expectations that the dissolution of the Soviet Union would lead to the United States' abandonment of Europe, American leaders chose to remain engaged in Europe and initiated reforms that would retain NATO's central role in preserving peace throughout the region. The practice of collective security was to be accompanied by organizational and normative changes allowing the Alliance to become more proactive in the management of security challenges. This chapter examines the accelerated process of regime change during the 1990s that ushered in the Alliance's further embrace of collective security, despite the challenges emerging from the European Union's efforts to establish a Common Foreign and Security Policy (CFSP) for its members and the persistence of a capabilities gap between the United States and the other members of NATO.

\section{Promoting East-West Cooperation}

The decline of the Soviet threat that had served as NATO's primary raison d'etre introduced a period of uncertainly within the Alliance. Hungary's former Deputy Defense Minister Istvan Gyarmati later noted, "The static conditions of 'high risk-high stability' in Europe have been replaced by the dynamic condition of 'low risk-low stability', which is characterized by a broader spectrum of diverse security challenges." Under such circumstances, the allies faced a more diffuse set of threats and the previous cohesion and unity could not be taken for granted. The allies' initial response to the dissolution of the Soviet Union was to pursue a policy of cooperation with both Russia and the former Warsaw Pact states. This emphasis on cooperation yielded a number of

\footnotetext{
${ }^{2}$ Istvan Gyarmati, "Hungary's Security and The Enlargement," in The Challenge Of NATO Enlargement, ed. Anton Bebler (Westport, CT: Praeger, 1999), 110.
} 
important initiatives over the next several years, including the creation of the North Atlantic Cooperation Council (NACC), the introduction of the Partnership for Peace (PfP) and the opening up of the Alliance to new member states.

NATO's post-Cold War strategy emphasizing cooperation with former adversaries was intended to reduce mistrust by increasing communication among member and non-member states and promoting a sense of shared responsibility for regional security. A transition from confrontation to cooperation could help socialize Warsaw Pact states in the ways of democracy, particularly regarding norms of non-violence, governmental transparency, and military subordination to civilian authority. This was consistent with President George H. W. Bush's call for a "new world order", where he stated his vision "of a new partnership of nations that transcends the Cold War. A partnership based on consultation, cooperation, and collective action, especially through international and regional organizations." ${ }^{\text {N }}$ NATO had performed this function throughout the Cold War with respect to West Germany, Portugal, Spain, Greece and Turkey, and advocates of expansion hoped the states of Central and Eastern Europe might similarly be reshaped into allies.

A commitment to greater cooperation was formally embraced by the Alliance in July 1990 when NATO heads of state issued the London Declaration calling for an end to the confrontation between East and West. The London Declaration included proposals to transform the Alliance and promote cooperation with NATO's former adversaries. This declaration called for the governments of the Soviet Union and Warsaw Pact states to

\footnotetext{
${ }^{3}$ Henry Kissinger, Diplomacy (New York: Simon \& Schuster, 1994), 804.
} 
visit NATO headquarters and to establish regular diplomatic liaisons with NATO. The allies claimed that these states "are no longer adversaries and reaffirm our intention to refrain from the threat or use of force against the territorial integrity or political independence of any state, or from acting in any other manner inconsistent with the purposes and principles of the United Nations Charter and with the CSCE [Commission on Security and Cooperation in Europe] Final Act." ${ }^{4}$ In addition, the London Declaration promised that the allies would work to overcome the legacy of decades of suspicion by pursuing "a major transformation... determined to create enduring peace on this continent."

The next challenge for the NATO allies was to develop a suitable strategy to bring their vision of a stable, peaceful region into reality. A Strategy Review Group was formed within a month of the London Summit to prepare a new Strategic Concept. Michael Legge, then NATO's Assistant Secretary General for Defense Planning and Policy and the chairman of the Strategy Review Group observed, "The former Harmel dual approach of dialogue and defense...[became] a triad of cooperation, dialogue and defense." A new Strategic Concept was adopted at NATO's Rome Summit in November 1991. The twelve drafts generated over sixteen months compared favorably to the decade of debate that preceded the adoption of a flexible response strategy in the 1960s.

\footnotetext{
${ }^{4}$ NATO Office of Information and Press. "Declaration On A Transformed North Atlantic Alliance Issued By The Heads Of State And Government Participating In The Meeting Of The North Atlantic Council, July 6, 1990," http://www.Nato.Int/Docu/Basictxt/B900706a.htm.

${ }^{5}$ Ibid.

${ }^{6}$ Michael Legge, "The Making Of NATO's New Strategy," NATO Review 39, no. 6 (December 199I): 12.
} 
Rather than seeking to undermine the governments of Eastern and Central Europe, NATO's new strategy hoped to limit instability in the East. The 1991 Strategic Concept stated, "the adverse consequences of instabilities that may arise from the serious economic, social, and political difficulties, including ethnic rivalries and territorial disputes, which are faced by many countries in Central and Eastern Europe...could, however, lead to crises inimical to European stability and even to armed conflicts, which could involve outside powers or spill over into NATO countries, having a direct effect on the security of the Alliance." 7 This strategy called for a reduced dependence on nuclear weapons as well as substantial reductions in the size and readiness of NATO military forces. These reductions were directed in favor of greater confidence-building activities to enhance transparency and improve communication, including the further verification of arms control agreements. The Alliance pursued a "broad approach to security...to draw all the consequences from the fact that security and stability have political, economic, social, and environmental elements as well as the indispensable defense dimension. ${ }^{\prime 8}$ NATO's new approach to security yielded several initiatives, beginning with the creation of the North Atlanic Cooperation Council (NACC).

NACC was formed in 1991 as a means of building upon ad-hoc military and diplomatic contacts to establishing regular consultations between NATO and the governments of European non-member states. The Council initially included all the members of the former Warsaw Pact as well as a number of states with observer status,

\footnotetext{
${ }^{7}$ NATO Office of Information and Press, "The Alliance's Strategic Concept Agreed By The Heads Of State And Government Participating In The Meeting Of The North Atlantic Council, November 8, 1991," http://www.Nato.Int/Docu/Basictxt/B911108a.htm.

${ }^{8}$ Ibid.
} 
including Austria, Finland, Slovenia, Sweden, and Switzerland. NACC had a mandate to overcome adversarial relationships stemming from the Cold War and to encourage confidence-building measures such as the verification of military force reductions, limits on the production of war material, and reciprocal over-flight agreements. The demands placed on the NACC by both member and non-member states soon proved to be overwhelming. Some participants referred to it as "a gigantic talking shop where the formal opening speeches usually filled up most of the time available and the conclusions of the proceedings merely restated the questions originally posed for debate." ${ }^{9}$ Within a couple of years, the responsibilities of NACC were delegated to its successor organizations, the Euro-Atlantic Partnership Council (EAPC) and PfP.

EAPC eventually replaced NACC with a more extensive series of consultations which were to be tailored to the individual needs of Partner states. EAPC complemented regional security cooperation seminars with direct political security consultations between the partner states and NATO representatives. Security cooperation seminars were hosted by many of the Partner states, including Georgia, Lithuania, Slovakia, Bulgaria, Uzbekistan, the Kyrgyz Republic, Kazakhstan and Azerbaijan. An Action Plan was developed calling for additional transparency measures and the development of disaster response capability to be shared among participating states. The Euro-Atlantic Disaster Response Coordination Center and Euro-Atlantic Disaster Response Unit emerged from this effort. Over the next several years, these organizations allowed

\footnotetext{
${ }^{9}$ Jonathan Eyal, "NATO's Enlargement: Anatomy of a Decision," Journal of International Affairs 73, no. 4 (October 1997):701.
} 
participating states to gain experience in combined operations while providing humanitarian relief to Kosovar refugees in Albania and flood victims in Ukraine.

Partnership for Peace represented an opportunity for NATO to form organizations that would actively pursue cooperation beyond a limited political dialogue. PfP was first proposed by U.S. Secretary of Defense Les Aspin at an informal meeting of NATO defense ministers in October 1993 and its implementation was made a top priority by American representatives to NATO. Then U.S. Permanent Representative on the North Atlantic Council (NAC) Robert Hunter described PfP as part of "a new experiment in security that marks a decisive end both to history's most destructive war and to its Cold War aftermath. For the first time, Europe has a chance to found Continent-wide security on a basis other than the balance of power - with its associated risks of a catastrophic clash of arms." ${ }^{\prime 10}$ PfP was envisioned as a way to move beyond consultations and enable non-member states to begin operating along side NATO forces using Allied doctrine and standard operating procedures. Within its first year, NATO shared hundreds of internal documents with participating states to encourage standardized military doctrine and the development of concepts of operation to be used in combined exercises and eventual realworld deployments.

PfP programs directed the conduct of combined planning efforts along with joint military exercises related to peacekeeping, search and rescue, and humanitarian operations. These efforts promised to improve the interoperability of military systems through the standardization of weapons, and commonality of logistical procedures among

\footnotetext{
${ }^{10}$ Robert Hunter, "Enlargement Part of a Strategy for Projecting Stability into Central Europe," NATO Review 43. no.3 (May 1995): 4.
} 
participating military forces. Hundreds of PfP-sponsored multilateral operations and exercises were eventually held, most modeled after NATO peacekeeping efforts in the Balkans and hosted by Partner states. ${ }^{11}$ The value to these activities among the nearly thirty participating nations led NATO Spokesman Jamie Shea to describe PfP as "a kind of a permanent Marshall Plan for defense."12

PfP allowed participants to gain most of the benefits of NATO, but lacked the collective defense guarantee maintained among member states. While the assistance with military reforms and cooperative activities were of sufficient value to traditionally neutral European states such as Austria and Switzerland, other states were motivated primarily by the future possibility of NATO membership. Duffield observed, "The more these countries interact during NATO military exercises, training for peacekeeping operations, and so on, the more they will have and will feel that they have a de facto military or security guarantee. In other words, the more that NATO is involved with them and the more they restructure their forces and decision-making processes to be compatible with NATO, the harder it will be for NATO to refuse to act if their security is endangered."13 Nonetheless, Poland, the Czech Republic and other participating states expressed some disappointment with PfP, viewing the program as another attempt by existing members to postpone a decision on their admission to the Alliance. Critics were even observed

\footnotetext{
${ }^{11}$ Notable PfP operations include Cooperative Support (beginning in 1995), Cooperative Zenith (beginning in 1996), Cooperative Safeguard (beginning in 1997), and Cooperative Jaguar (beginning in 1998).

${ }^{12}$ NATO Office of Information and Press, "How Did NATO Survive The Cold War?" NATO Video Lecture Transcript, March 11, 2004," http://www.Nato.Int/Multi/Video/Lectures/031 104/V031104al.htm.

${ }^{13}$ John Duffield, "The North Atlantic Treaty Organization and Alliance Theory," in Explaining International Relations since 1945, ed. Ngaire Woods (Oxford: Oxford University Press, 1996), 117.
} 
replacing the word "Peace" with "Postponement" or "Procrastination" or even "Prevarication", because of their impression that PfP was simply a means of stalling on the question of NATO expansion. ${ }^{14}$

There was a great deal of uncertainty regarding the desirability of NATO expansion in the 1990s. This was not a question of legality, since the Alliance had previously added Greece, Turkey, West Germany, and Spain. Article 10 of the North Atlantic Treaty provides for expansion, stating "The Parties may, by unanimous agreement, invite any other European State in a position to further the principles of this treaty and to contribute to the security of the North Atlantic area to accede to this treaty." 15 Alliance membership was attractive to a number of former Warsaw Pact states because it would bring them closer to prosperous Western European states, while providing a security guarantee and helping them normalize relations with Russia. Many European members of the Alliance were ambivalent towards the idea of expansion. The strongest supporters were states along NATO's periphery. Germany was particularly anxious to create an economic and security buffer between itself and the former Soviet states by making Poland, the Czech Republic, or Slovakia NATO's eastern border. German Defense Minister Volker Ruhe wrote, “A situation in which Germany's east border is the border between stability and instability in Europe is not sustainable in the

\footnotetext{
${ }^{14}$ David Yost, NATO Transformed: The Alliance's New Roles in International Security (Washington D.C.: United States Institute of Peace Press, 1998), 98.

${ }^{15}$ NATO Office of Information and Press. "Text of The North Atlantic Treaty, April 4, 1949" http://www.nato.int/docu/basictxt/treaty.htm.
} 
long run. Germany's eastern border cannot be the eastern border of the European Union and NATO. Either we export stability of we import instability." 16

Critics of expansion argued that this process was not only unnecessary, but could itself prove to be a source of insecurity. PfP was indeed advocated as an alternative to expansion by many European and American officials concerned about retaining the credibility of NATO's collective defense pledge. Among the American officials advocating this view were U.S. Secretary of Defense Les Aspin and Chairman of the Joint Chiefs of Staff General John Shalikashvili, who "opposed expansion and, in particular, feared diluting the effectiveness of NATO."17 Critics noted that the former Warsaw Pact states had armed forces that were militarily incompatible with those of NATO member states. The modernization of these forces could be expected to take many years and prove very costly. Experience had shown that it was nearly a decade or so before the German and Spanish militaries could integrate fully with NATO forces. The cost of military reforms among the prospective member states would also compete with funding for much-needed social and political reforms. International financier George Soros expounded this view writing, "The problems of Central and Eastern Europe require political integration and economic prosperity, not the extension of military alliances. The countries of the region need political, moral, and economic assurance that they are indeed part of the West and of the world of open societies. To give them armies and military alliances instead misconstrues the threat. In fact, the expansion of NATO

\footnotetext{
${ }^{16}$ Volker Ruhe, "Shaping Euro-Atlantic Policies: A Grand Strategy for a New Era," Survival 35, No. 2 (Summer 1993): 130.

${ }^{17}$ James Goldgeier, "NATO Expansion: The Anatomy Of A Decision," The Washington Quarterly 21, no. 1 (Winter 1998): 88.
} 
can easily turn into a self-fulfilling prophesy, generating the very dangers against which it is meant to defend."18

A related risk associated with expansion was the chance of the Alliance being drawn into existing interstate conflicts involving candidate states. Prospective NATO member states were involved in numerous disputes in the mid-1990s that had the potential to escalate into military conflict. Hungary had difficult relations with Romania, Yugoslavia and Slovakia over the treatment of ethnic Hungarian minorities living in these states. Romania also had territorial issues with Moldova and Ukraine that were likely to bring Russia into any potential conflict. Poland's border with Belarus was inadequately monitored, which made Poland likely to become involved in any future internal conflicts within Belarus. ${ }^{19}$

Proponents of expansion also had to look for ways to overcome Russian opposition to expansion. Since the early 1990s, NATO member governments had assured Russia that any loss of influence in Europe would not be translated into a Western "gain”. Russian President Boris Yeltsin had expressed his opposition to

${ }^{18}$ George Soros, "Can Europe Work? A Plan to Rescue the Union," Foreign Affairs 75 no. 5 (September/October 1996): 12. Later events found these fears to be overstated. A key RAND study finds that prospective membership in NATO had indeed contributed to increased investor confidence and the accelerated economic growth that accompanies investment capital. The extension of NATO's security guarantee is thought to have reduced pressure on new members to seek costly and potentially destabilizing military capabilities. See David Ochmanek, NATO's Future: Implications for U.S. Military Capabilities and Posture (Washington DC: RAND, 2000).

${ }^{19}$ Once again, these risks proved to be manageable. NATO Secretary General Javier Solana observed in 1999, "The possibility of NATO membership has already given many nations of Central and Eastern Europe an incentive to put to an end to old quarrels, border disputes or other unresolved security-related issues. Already a number of bilateral treaties have been signed, including Romania-Hungary, RomaniaUkraine, Germany-Czech Republic, Hungary-Slovakia and Poland-Ukraine, to cite just a few. This is a truly fantastic achievement." Javier Solana, "NATO Beyond Enlargement," in The Challenge of NATO Enlargement, ed. Anton Bebler (Westport, CT: Praeger, 1999), 5. 
expansion on numerous occasions and his National Security Advisor Alexander Lebed had even gone so far as to predict the outbreak of World War III if NATO tried to expand. Expansion without Russian concurrence might undermine key arms control agreements such as the Conventional Forces Europe (CFE) agreement and Strategic Arms Reduction Treaties. Expanding NATO hundreds of miles eastward raised concerns among Russian military leaders due to the inability of Russian air defense systems to provide adequate warning in the event of a future missile strike. These and other considerations made former Secretary of State and United States ambassador to the Soviet Union George F. Kennan particularly critical of expansion. Kennan labeled proposals for NATO expansion "in the highest degree deplorable" and warned "it never pays. . for one great power to take advantage of the momentary weakness or distraction of another great power in order to force upon it concessions it would never have accepted in normal circumstances. . . over the long run, it almost always revenges itself." 20 Kennan later observed, "Bluntly stated, expanding NATO would be the most fateful error of American policy in the entire post-Cold War era. Such a decision may be expected to inflame the nationalistic, anti-Western and militaristic tendencies in Russian opinion; to have an adverse effect on the development of Russian democracy; to restore the atmosphere of the cold war to East-West relationship; and to impel Russian foreign policy in directions decidedly not to our liking."

\footnotetext{
${ }^{20}$ George Kennan, At A Century's Ending: Reflections, 1982-1995. (New York: W.W. Norton, 1996), 330.

${ }^{21}$ George Kennan, “A Fateful Error.” The New York Times, February 7, 1997.
} 
Despite the concerns of critics within and outside his administration, President Clinton expressed confidence that the Alliance would expand as early as January 1994, when during a speech at NATO’s Brussels Summit he stated, "While the Partnership is not NATO membership, neither is it a permanent holding room. It changes the entire NATO dialogue so that now the question is no longer whether NATO will take on new members, but when and how." 22 The failure of European states to effectively intervene in the Balkans resulted in calls for the Clinton administration to restructure its European policy and play a more prominent position in European affairs. Some analysts suspected election year politics also played a role in the administration's conversion from a policy of "Russia-first" to a pro-expansion position in the fall of 1994. One scholar concluded, "The decision to accelerate the timetable for NATO's expansion was based neither on strategic logic nor military threat, but was domestically driven. President Clinton's bid for votes among those with strong cultural, ethnic, and religious ties to Central and Eastern Europe led him to declare in Detroit on October 22, 1996, in the final two weeks of a bitterly contested election campaign, that he wanted the first group of Central and Eastern European countries ... admitted in 1999.,23

The NAC called for a study on the implications of NATO expansion in December 1994. The resulting Study on NATO Enlargement strongly advocated the expansion of the Alliance and cited many favorable outcomes resulting from expansion. The study recommended that expansion be approached as a process rather than a single event, so

\footnotetext{
${ }^{22}$ White House Office of Press Secretary. "Press Conference By The President With Visegrad Leaders, January 12, 1994.". http://www.Friends-Partners.Org/Oldfriends/News/Summit/Visegrad.Pressconf.html.

${ }^{23}$ Alvin Rubenstein, "NATO Enlargement vs. American Interests," Orbis 42, no. 1 (Winter 1998): 37.
} 
states not immediately invited to join NATO could expect to be considered again at a later date. The promise of NATO membership was expected to encourage further democratic reforms within candidate states, such as greater civilian control over military forces. The study also found that expansion would help improve relations among states in the region by encouraging greater consultation and cooperation. Transparency in defense planning and budgeting could also improve relations among these states and contribute to regional stability. Candidate states would be expected to pursue policies that "promote stability and well being by economic liberty, social justice, and environmental responsibility... [and] establish appropriate democratic and civilian control of their defense force. ${ }^{, 24}$

The Study on NATO Enlargement also resolved the question of whether candidate states would be offered "full" membership in NATO. Several NATO member states had specified conditions regarding their membership. Both Norway and Denmark prohibited the deployment of nuclear weapons on their territory and specified limitations on the peacetime stationing of foreign forces within their borders. France participated in political decision-making organizations, but had not participated in NATO's integrated military command since 1964. New Alliance members would be offered full membership and given equal status in the combined military planning of the Alliance, including planning for contingencies involving nuclear weapons. While separate assurances were given to Russia regarding the deployment of nuclear weapons on the

\footnotetext{
${ }^{24}$ NATO Office of Information and Press, "Study on NATO Enlargement, September 1995," http://www.nato.int/docu/basictxt/enl-9501.htm.
} 
territory of new member states, there were no other limitations on the rights and responsibilities of new member states.

Critics of expansion questioned the alleged relationship between democratization and NATO membership. The logic of causality could be challenged because NATO requires that aspirant countries have a working democratic system in place before they are accepted as members. As Reiter found in his study of Central European governments, "NATO membership was not necessary for democratization because each [candidate state] already has a strong national commitment to democracy. ${ }^{, 25}$ Like-minded critics were unconvinced that the promise of eventual membership could be credited with the prerequisite reforms within candidate states. Mandelbaum noted, "The countries under active consideration are precisely those best placed to make a successful transition to democracy and free markets without NATO membership." ${ }^{26}$ Bebler similarly observed, "If NATO enlargement is indeed to improve security and stability in the former Eastern Europe, as publicly claimed, then the invitations ought to have been extended to the weakest and neediest among the post-communist states in transition, and not to the militarily and economically strongest and those less exposed to potential external threats." 27

\footnotetext{
${ }^{25}$ Dan Reiter, "Why NATO Enlargement Does Not Spread Democracy," International Security 25, no.4 (Spring 2001): 60.

${ }^{26}$ Michael Mandelbaum, "Preserving The New Peace: The Case Against NATO Expansion." Foreign Affairs 74, no. 3 (May/June 1996): 13.

${ }^{27}$ Anton Bebler, "Postscript," in The Challenge Of NATO Enlargement, ed. Anton Bebler (Westport, CT: Praeger Press, 1999), 205.
} 
By 1996, twelve states had formally expressed interest in joining NATO. Each of these states entered intensive talks with NATO representatives to learn how the Alliance works and to provide information on progress toward meeting the criteria for membership. Conditions in many of these states were far too unstable to make them attractive candidates for membership. Although Romanian leaders expressed a desire to join the Alliance, their pace of political and economic reform was unimpressive. Slovakia also continued to experience internal political turmoil that made some observers question Prime Minister Meciar's commitment to democracy. Russian officials wanted to clarify that there was no prohibition against Russia's eventual eligibility for membership. While no explicit barrier existed, there was little expectation that Russia would be invited into the Alliance in the immediate future.

American leadership was apparent throughout the process of expansion. Assistant Secretary of State Richard Holbrooke led a team of negotiators that simultaneously tried to build a consensus within the Alliance while reassuring the Russians that NATO expansion would have no adverse security implications for them. Russian concurrence came in May 1997 with the signing of the Founding Act on Mutual Relations, Cooperation, and Security, which had been primarily negotiated between American and Russian officials. German leaders, while remaining strong supporters of NATO expansion, were put off by the unilateral approach taken by the Americans. French involvement had also been limited, and their support for including Romania and Slovenia in the list of invitees was virtually ignored. The unwillingness of American diplomats to 
give their European allies a larger role in the process prompted at least one French official to ask, "When exactly did the Americans go from leadership to hegemony?"28

Poland, the Czech and Slovak Republics and Hungary soon emerged as the most likely candidates for future membership. Poland's candidacy benefited from the international recognition of its important role in challenging Soviet authority in the 1980s. Poland also had a very high level of domestic public support for NATO membership and demonstrated its readiness by increasing defense spending in line with Alliance guidance. Finally, Poland had a strong record as a contributor of troops for UN peacekeeping operations, providing more troops in 1997 than any other state. While the public support for NATO membership and the commitment to military modernization was lower in the Czech Republic, its location between Germany and Poland and the charismatic leadership of President Vaclav Havel made it an attractive candidate. Hungary did not have geographic contiguity with the rest of the Alliance members, but had steadily pursued economic and political reforms and continued to play an active role in support of NATO operations in the Balkans.

Economic and political readiness were among the determining factors for these three states. As President Clinton remarked to the Senate as the membership protocols went forward for confirmation, "Poland, Hungary, and the Czech Republic have been leaders in Central Europe's dramatic transformation over the past decade and already are a part of NATO's community of values. They each played pivotal roles in the overthrow of communist rule and repression, and they each proved equal to the challenge of

\footnotetext{
${ }^{28}$ Steven Erlanger, "Yeltsen Basks at Summit; Some Europeans are Cool to the U.S.," The New York Times, May 30, 1997.
} 
comprehensive democratic and market reform. Together, they have helped to make Central Europe the Continent's most robust zone of economic growth. ${ }^{29}$ NATO leaders extended invitations to Poland, Hungary and the Czech Republic at the July 1997 summit in Madrid and these states formally joined NATO during the Washington Summit marking the Alliance's 50th anniversary in April 1999.

\section{NATO Interventions in the Balkans}

While continuing to support the overall strategy of collective defense, the Alliance found it necessary to strengthen its commitment to collective security in the post-Cold War era. Contemporary NATO documents define collective security as "political solidarity among member countries; the promotion of collaboration and strong ties between them in all fields where this serves their common and individual interests; the sharing of roles and responsibilities and recognition of mutual commitments; and a joint undertaking to maintain adequate military forces to support Alliance strategy and policy. ${ }^{30}$ Collective security is practiced through the conduct of non-Article Five missions such as crisis management and peacekeeping. Norman Ray, then NATO Assistant Secretary General for Defense Support, observed "The NATO of today has moved far beyond the core task of safeguarding its members' territory. It is actively trying to create the conditions for long-term stability in the entire Euro-Atlantic area. To

\footnotetext{
${ }^{29}$ White House Office of Press Secretary, "Clinton Transmittal To Senate Of Protocols To NATO Treaty, February 11, 1998," http://www.fas.org/man/nato/offdocs/us_98/98021108_tpo.html.

${ }^{30}$ NATO Office of Information and Press. "NATO Handbook." http://www.nato.int/docu/handbook/2001/.
} 
this end, NATO has assumed new missions, undertaken major internal reforms and introduced a qualitatively new era of partnership and security cooperation in Europe."31

Out-of-area missions had historically been avoided and the topic remained divisive among the allies throughout the early 1990s. The 1967 Harmel Report advised against such actions, stating "Nor is it advisable for NATO to intervene in conflict situations elsewhere in substitution for an ineffective United Nations organization; indeed, NATO action might well provoke Soviet intervention and accordingly spread the danger. The legal objections against the extension of NATO responsibilities outside the NATO area are well founded. The treaty contains no provisions for operational activities of the Alliance in other regions.. ${ }^{32}$ The revised strategy laid out in the 1991 Security Concept also omitted such missions, noting "The Alliance is purely defensive in purpose: none of its weapons will ever be used except in self-defense... The role of the Alliance's military forces is to assure the territorial integrity and political independence of its member states, and thus contribute to peace and stability in Europe."33 Out-of-area missions are particularly vulnerable to collective action problems because the territorial integrity of member states are not directly threatened. In the absence of any consensus among Alliance members regarding the conduct of such missions, NATO would be unable to act.

\footnotetext{
${ }^{31}$ Norman Ray, "Security Cooperation And The New NATO," The Challenge Of NATO Enlargement, ed. Anton Bebler (Westport, CT: Praeger Press, 1999), 10.

${ }^{32}$ NATO Office of Information and Press, "The Future Tasks Of The Alliance - The Harmel Report" http://www.nato.int/docu/basictxt/b67123a.htm.

${ }^{33}$ NATO Office of Information and Press. "The Alliance's Strategic Concept Agreed By The Heads Of State And Government Participating In The Meeting Of The North Atlantic Council, November 8, 1991," http://www.nato.int/docu/basictxt/b911108a.htm
} 
The outbreak of war among former Yugoslav republics served as the first major challenge to European security after the Cold War and stood at the center of the debate over the practice of collective security. The Federal Republic of Yugoslavia had been cobbled together in the aftermath of World War Two and remained unified throughout the Cold War despite ethnic divisions between Serbia and the rest of republics (Slovenia, Croatia, Bosnia-Herzegovina, Montenegro, Macedonia). Over a period of nearly forty years, Josip Broz (Tito) demonstrated an extraordinary ability to contain the violence between ethnic factions. Tito's death in 1980, followed by years of deteriorating economic conditions weakened the already tenuous links between the republics. This process was fueled by leaders such as Slobodan Milošević who manipulated ethnic divisions to increase Serbia's power and influence over the other republics. Milošević called for the creation of a greater Serbia encompassing all territory in the former Yugoslavia occupied by ethnic Serbs. Milošević's actions were unacceptable to several of the other republics, leading them to seek independence from Serbian dominance. Slovenia and Croatia declared independence in 1991, which was forcefully opposed by the Serbian-controlled Yugoslavian Peoples Army (JNA) and ethnic Serbs living within these republics. JNA troops were driven from Slovenia in ten days, but fighting was much more prolonged in Croatia.

Any solution to the violence stemming from the breakup of Yugoslavia was initially left to other international organizations. The UN passed Security Council Resolution 713 declaring an arms embargo on Yugoslavia and began a series of negotiations to help find a resolution to the conflict. While the chronic violence in this area was of great concern to neighboring states, it was less of a concern for those 
Alliance members more distant from the conflict, such as the United States. Many European leaders welcomed the opportunity to address the conflict without American leadership. French, Belgian, and Spanish representatives to the CSCE reduced the likelihood of American involvement by insisting that any peacekeeping request be made to individual governments and not to NATO headquarters. On the occasion of a breakthrough in negotiations between Slovenia and Serbia, Jacques Poos, the Foreign Minister of Luxembourg and holding the presidency of the European Community, declared "This is the hour of Europe, not the hour of the Americans!"34

European Community and UN negotiators initially succeeded in achieving a ceasefire between Serbia and Croatia without American assistance. In April 1992, the UN organized UNPROFOR to oversee the ceasefire in Croatia. A lasting peace was not achieved and fighting broke out again in early 1993. Unable to stop the fighting again, the UN created Protected Areas (UNPAs) to encourage the combatants to demilitarize key regions and discontinue ethnic cleansing. UNPAs were poorly suited to both tasks, and UN monitors were primarily left to simply document the ongoing atrocities. The continued efforts of the EC and UN were even less successful in ending the factional fighting in Bosnia-Herzegovina. A referendum was held in March, 1992 and the participants overwhelmingly favored independence. This referendum had been boycotted by ethnic Serbs, who declared their own independent republic within BosniaHerzegovina. Ethnic cleansing was rampant as each side attempted to link together territory under its control. Reflecting on the efforts of the UN and EC to bring peace to

\footnotetext{
${ }^{34}$ Andraes Kinitis, "The EU's Foreign Policy And The War In Former Yugoslavia," in Common Foreign And Security Policy: The Record And Reform, ed. Martin Hollad (London: Cassell, 1992), 150.
} 
the region, the Canadian Charge d'Affaires in Croatia remarked "Unless America is engaged, it simply doesn't work."35

The absence of American leadership contributed to the unwillingness of NATO to pursue collective security in the early 1990s. American leaders were anxious to reduce, rather than increase the United States' role in European security in the period immediately following the end of the Cold War. The U.S. government took the position that it would not become directly involved in the fighting, but would simply strive to contain the conflict. Without American support for intervention, NATO was unable to take collective action.

When the level of violence in Croatia and Bosnia-Herzegovina later escalated to levels that swayed American leaders toward intervention, there was still disagreement regarding the Alliance's role as a peacemaker. Historical ties to the region divided the allies, with Greece and a handful of other NATO states being more supportive of Serbia's efforts to prevent the breakup of Yugoslavia. Mueller found that two conflicting assessments of the underlying causes of the conflict further divided European and American leaders. ${ }^{36}$ The dominant view within the French and British governments characterized the Yugoslav conflict as a civil war fueled by ethnic rivalries. According to Mueller, "If the war were the consequence of endemic cultural forces, then it had no culprits. All sides were equally guilty and equally innocent - victims of forces beyond

\footnotetext{
${ }^{35}$ Leonard Cohen and Alexander Moens, "Learning the Lessons of UNPROFOR: Canadian Peacekeeping in the Former Yugoslavia," Canadian Foreign Policy 6, no. 2 (1999): 85-101.

${ }^{36}$ Karl Mueller, "The Demise of Yugoslavia And The Destruction Of Bosnia: Strategic Causes, Effects, And Responses," in Deliberate Force: A Case Study In Effective Air Campaigning, ed. Robert Owen. (Montgomery, AL: Air University Press, 2000), 1-37.
} 
their control. If that were the case, then the proper role of an intervention was that of neutral mediator." ${ }^{37}$ American leaders were quicker to view the Serbs as aggressors in the region. The dominant American view was that the Yugoslav conflict was the result of political manipulation by Serbian leaders exploiting the situation for their own interests. American leaders favored a peacemaking strategy aimed at compelling the Serbs to agree to a political settlement. This normative difference in the perception of the causes of the conflict contributed to the delay in NATO's action. As acknowledged earlier, Claude notes that the practice of collective security requires states to achieve a consensus on the nature of aggression, as well as a solution. ${ }^{38}$

NATO's political organizations eventually forged an incremental set of agreements that helped the allies achieve a consensus on both the nature and desired resolution of the conflict. NATO first became involved in the conflict by agreeing to enforce the existing UN-sponsored sanctions on Yugoslavia. In 1992, NATO leaders agreed to "support, on a case-by-case basis and in accordance with our own procedures, peacekeeping operations under the authority of the UN Security Council." ${ }^{39}$ Operation Provide Promise was first authorized, consisting of thousands of flights by American, German, and French air forces to bring humanitarian relief supplies to Sarajevo and surrounding areas. A more intrusive effort to decrease the violence in the region was undertaken by NATO and Western European Union (WEU) forces through Operation

\footnotetext{
${ }^{37}$ Ibid, 462.

${ }^{38}$ Inis Claude, “The Balance of Power Revisited," Review of International Studies 15 (1989): 77-85.

${ }^{39}$ NATO Office of Information and Press. "Communiqué Issued By The Ministerial Meeting Of The North Atlantic Council, December 17, 1992," http://www.nato.int/docu/comm/49-95/c921217a.htm.
} 
Sharp Guard. This effort consisted of joint naval patrols in the Adriatic Sea to enforce the UN arms embargo against the former Yugoslav republics. ${ }^{40}$ However, as American sympathies for the Bosnian Muslims grew, the United States began to limit its participation in these patrols. The United States also began withholding needed aerial reconnaissance and satellite intelligence for the operation while funding air drops of weapons and military equipment to the Bosnian Army. The Clinton administration became increasingly convinced of the advantages of a "lift and strike" strategy and lobbied its NATO allies for support. This strategy called for a lifting of the United Nations-imposed arms embargo in conjunction with the threat of NATO air strikes in the event that either side failed to pursue negotiations.

Operational cooperation between UN and NATO forces began with the activation of Operation Sky Watch to enforce a ban on military flights over Bosnia-Herzegovina in accordance with United Nations Security Council Resolution (UNSCR) 781. This effort was strengthened in 1993, when UNSCR 816 banned all unauthorized flights over Bosnia-Herzegovina. ${ }^{41}$ Operation Deny Flight emerged and grew to include close air support missions to protect UN personnel, as well as offensive air support to include the targeting of air defenses, command and control sites, and weapons storage depots. Deny Flight lasted for three years and marked NATO's first foray into combat with the shooting down of four Bosnian-Serb aircraft violating the no-fly zone in February 1994.

\footnotetext{
${ }^{40}$ A number of states disregarded the UN embargo and routinely supplied arms to the combatants in the region. States that were lax on controls included Albania, Macedonia, Italy, Greece, Iran, Saudi Arabia, and Hungary. Because the most of these violations of the embargo were occurring over land, Operation Sharp Guard was primarily a symbolic exercise.

${ }^{41}$ United Nations Documentation Center, "United Nations Security Council Resolution 816, March 31, 1993," http://daccessdds.un.org/doc/UNDOC/GEN/N93/187/17/IMG/N9318717.pdf?OpenElement.
} 
NATO's participation in the ground war soon followed in November 1994 with an airstrike on Udbina airfield in Croatia.

Under Operation Deny Flight, a "two-key" system of control was established over NATO forces. This arrangement required authorization from within both NATO and the UN prior to any close air support or offensive strike missions. In practice, NATO requests for strikes were commonly denied or limited by the UN. Owen relates a number of incidents where the use of airpower was frustrated by this system of control. ${ }^{42}$ Bosnian Serbs took approximately 350 UN observers hostage in May 1995 in order to pressure NATO into halting its close air support operations. Bosnian Serbs also shot down an American F-16 over the no-fly zone in an effort to humiliate NATO and the UN. In July, UN forces came under attack in the city of Srebrenica and requested close air support. While NATO commanders authorized the strikes and readied the aircraft for attack within minutes, UN officials did not provide their authorization for two days. UN authorization came too late to prevent the fall of the city to Serbian forces. The ineffectiveness of the current strategy was apparent by the continued presence of heavy weapons in the UN-designated exclusion zone and Bosnian Serb offensives within UN "safe areas". U. S. Secretary of Defense William Perry expressed American frustrated with the situation in Bosnia-Herzegovina, stating "Paralyzed into inaction, NATO

\footnotetext{
${ }^{42}$ Robert Owen, ed. Deliberate Force: A Case Study In Effective Air Campaigning (Montgomery, AL: Air University Press, 2000).
} 
seemed to be irrelevant in dealing with the Bosnian crisis. . . It appeared to me that NATO was in the process of unraveling., ${ }^{43}$

NATO allies finally consented to the more aggressive American strategy after the fall of Srebrenica. Evidence of an apparent massacre of thousands of Bosnian Muslims during and immediately after the assault on the city contributed to an increase in support for a more comprehensive air campaign. NATO leaders issued an ultimatum to the Bosnian Serbs to refrain from attacking Sarajevo or face an escalated military response. A Serbian mortar attack on Sarajevo's Markale marketplace in August 1995 killed 350 people and served as the trigger for Operation Deliberate Force (ODF). UN and NATO officials authorized a series of airstrikes that lasted twenty-two days, interrupted by an unnerving three-day pause in the bombing toward the beginning of the campaign. The scale of the attack was much smaller than that of Desert Storm in Iraq a few years earlier. Forty-eight targets were struck by 1,026 weapons - the equivalent of a single days' activity in Desert Storm. ${ }^{44}$ NATO's air campaign, combined with Muslim and Croat territorial gains, pushed the Bosnian Serbs toward accepting a ceasefire and beginning negotiations to end the fighting while retaining Bosnia-Herzegovina as a single state. A peace agreement was signed in Dayton, Ohio sixty days after the airstrikes had begun. NATO's military intervention in Bosnia-Herzegovina brought with it the responsibility for a long-term peacekeeping presence in the region. Implementation Force (IFOR) and the follow-on Stabilization Force (SFOR) called for 60,000 and 30,000

\footnotetext{
${ }^{43}$ Sean Kay, NATO and the Future of European Security. (Lanham, MD: Rowman and Littlefield, Inc, 1998) 80.

${ }^{44}$ Owen, Deliberate Force, 485.
} 
troops respectively to serve in Bosnia-Herzegovina. IFOR, also known as Operation Joint Endeavor, was characterized by NATO officials as “NATO's first ever ground force operation, its first-ever deployment 'out-of-area,' and its first ever joint operation with NATO's Partnership for Peace partners and other non-NATO countries. ${ }^{, 45}$ Both IFOR and SFOR were primarily organized to prevent another outbreak of factional fighting, although the troops assigned to these operations also helped organize elections, rebuild infrastructure and conduct de-mining activities. ${ }^{46}$ The presence of NATO troops in Bosnia-Herzegovina contributed to more stable conditions within the state, enabling free and fair elections to be held in 1996.

NATO's experience in Bosnia-Herzegovina provided the allies with an opportunity to demonstrate the validity of collective security and raise NATO's profile as the primary forum for transatlantic security. NATO's eventual willingness to put an end to the fighting in Bosnia-Herzegovina indicated the growing support for a collective security regime among Alliance members. The Alliance had unanimously agreed to undertake its first out-of-area mission and the resulting commitment to collective security went a long way toward addressing speculation that the Alliance was no longer relevant to European security. The division and inaction plaguing the Alliance during the first few years of the crisis had been replaced by a shared commitment to restore peace to the

\footnotetext{
${ }^{45}$ NATO Office of Information and Press, NATO Basic Fact Sheet: NATO's Role In Bringing Peace To The Former Yugoslavia, March 1997 (Brussels: NATO Office of Information and Press, 1997).

${ }^{46}$ Fourteen Partnership for Peace countries participated in IFOR (Albania, Austria, Bulgaria, Czech Republic, Estonia, Finland, Hungary, Latvia, Lithuania, Poland, Romania, Russia, Sweden and Ukraine) along with four additional states (Egypt, Jordan, Malaysia, and Morocco). Four more countries (Argentina, Ireland, Slovakia and Slovenia) also joined SFOR, bringing the total of non-NATO participating countries to twenty-two.
} 
region. However, while factional violence was suppressed in this part of the region, there was little these forces could do about the increasingly violent confrontations between Serbians and ethnic Albanians in Kosovo.

Some of the unease expressed in the early 1990s regarding the practice of collective security returned, albeit in a lesser form, when hostilities broke out in Kosovo. Kosovo had lost much of its autonomy in 1989 when President Milošević had first attempted to establish a Greater Serbia out of the republics of the former Yugoslavia. Kosovar Albanians, which made up the majority of the population, resisted Serbian efforts to exercise greater control over Kosovo. By mid-1998, the Yugoslav Army and Serbian paramilitaries had begun an ethic cleansing campaign targeting Kosovar Albanians, resulting in thousands of deaths and some 400,000 refugees. This resurgence of violence would once again test of the Alliance's commitment to collective security. Whereas it took more than three years for the NAC to reach a decision regarding NATO's intervention in Bosnia-Herzegovina, NATO leaders were able to make the decision to intervene to sin Kosovo much more quickly. However, the conduct of the campaign was fraught with difficulties and marked by numerous disagreements among the Allies.

The UN had deployed international observers to Kosovo, but the Security Council remained divided over the resumption of sanctions or an explicit authorization of force against Serbia. UNSCRs 1160 (March 1998), 1199 (September 1998) and 1203 (October 1998) uniformly condemned the violence in Kosovo and urged participation in an OSCE Verification Mission, but fell short of explicitly authorizing the use of force to restore 
peace and security in the region. ${ }^{47}$ French and German officials felt UN authorization was a necessary prerequisite to NATO's use of force, while some other European policymakers were opposed to the idea of threatening to use force at all. A divide had formed among advocates of a military intervention, which included American strategists, and those favoring continued diplomacy.

However, as the situation in Kosovo deteriorated further, the NAC was able to build a consensus in favor of the more aggressive strategy of military intervention. The emerging consensus once again demonstrated the value of NATO's norms, rules, and procedures. The political and military committees were able to investigate topics of interest to member governments and provide detailed contingency plans for their consideration. Member states were able to express their concerns privately and negotiate a compromise without extensive public debate. The practice of consensus avoided the formal casting of votes within the NAC, so member states would not be publicly portrayed as "winning" or "losing" on a particular issue. Participants in the process, including General Wesley Clark, Supreme Allied Commander, Europe during Operation Allied Force (OAF), viewed these rules and procedures as an essential means of enabling government leaders to balance national interests with those of NATO as a whole. During OAF, General Clark found that the NAC served as a "shock absorber, enabling ministers

\footnotetext{
${ }^{47}$ United Nations Documentation Center, "United Nations Security Council Resolution 1160, March 31, 1998," http://daccessdds.un.org/doc/UNDOC/GEN/N98/090/23/PDF/N9809023.pdf? OpenElement. "United Nations Security Council Resolution 1199, September 12, 1998," http://daccessdds.un.org/ doc/UNDOC/GEN/N98/090/2279/96/PDF/N9827996.pdf?OpenElement. "United Nations Security Council Resolution 1203, October 24, 1998," http://daccessdds.un.org/doc/UNDOC/GEN/N98/ 321/21/PDF/N9832121.pdf?OpenElement.
} 
to express publicly their reservations about a particular target or activity, but then privately accept the allied consensus to move ahead with the campaign."

Rather than postponing any threat of military force until after UN authorization, NATO allies decided to begin planning for the use of military force in Kosovo and issued an activation order to assemble forces for airstrikes in the fall of 1998. Continued Russian obstruction within the Security Council led to a decision by the NAC in November 1998 to discontinue any reliance on UN authorization as a condition for military action. NATO leaders also rejected a proposal to act under a mandate from the Organization for Security and Cooperation in Europe (OSCE). Given the shortcomings of the "dual-key" system of command and control in Bosnia-Herzegovina, these leaders favored a single chain of command. While UN or OSCE support was desirable, the collective will of NATO's nineteen member states was considered sufficient political legitimacy for whatever military action the Alliance might wish to take to restore peace in Kosovo.

With the implied threat of a pending NATO military intervention, a Contact Group consisting of the United States, Great Britain, France, Germany, Italy, and Russia continued to negotiate with both Serbian and Kosovar Albanian representatives through March 1999. The talks ended when the Kosovar Albanian representatives signed a peace accord that was subsequently rejected by the Serbians. Serbian military and police forces immediately began a new offensive against the ethnic Albanians in Kosovo, which finally triggered NATO airstrikes. According to NATO estimates, by the beginning of

\footnotetext{
${ }^{48}$ Wesley Clark, Waging Modern War (New York: Public Affairs, 2001), 429.
} 
April 1999 an estimated 1.5 million people (equivalent to 90 percent of the population of Kosovo) had been expelled from their homes and driven into Bosnia-Herzegovina, Macedonia, Albania and other European countries. ${ }^{49}$

OAF was conducted as a combined military campaign, but followed an operational plan primarily laid out by American personnel serving on the SHAPE and EUCOM staffs. American planners identified virtually all the targets and kept specific target information out of the hands of other NATO personnel. The NAC was initially given target categories rather than exact targets because of fear of leaks. U.S. Navy Vice Admiral Murphy later recalled, "The target lists were not made available to NATO until the day of planning required ... master-target files was [sic] retained in U.S.-only channels and then shared with selected allies, as necessary for consultation. But this was a reflection of the very real concern that all the senior commanders had, that we didn't have an airtight security system within some areas of the NATO operation." ${ }^{50}$ This concern was justified early in the campaign after evidence was uncovered that key portions of the NATO operations plan were being leaked to Serbian officials. A U.S. Department of Defense spokesman acknowledged the leaks, characterizing them as "one of the costs of coalition warfare."

\footnotetext{
${ }^{49}$ NATO Office of Information and Press, "NATO Handbook."

${ }^{50}$ U.S. House of Representatives, "Vice Admiral Daniel Murphy Testimony to the House Armed Services Committee, Military Readiness Subcommittee, October 26, 1999," http://www.house.gov/hasc/testimony/ 106thcongress/99-10-26murphy.htm.

${ }^{51}$ Roberto Suro and Thomas Ricks, "Pentagon Acknowledges Kosovo Air War Data Leaked," The Washington Post, March 10, 2000.
} 
The air campaign was divided into three increasingly destructive phases, with the NAC exercising the authority to move from one phase to the next. The first phase consisted of fielded military forces, while the second phase added dual-use infrastructure such as bridges and petroleum depots, and the third phase attacked Serbian government facilities throughout the country. General Clark observed, "fundamental differences within the Alliance on the nature of the campaign. The U.S. was increasingly committed to the idea of strategic strikes, going after the heart of Milošević's power. The European, or at least the French and a few others, were more interested in limiting the strikes to Kosovo, trying to hit the ground forces, and avoiding actions that might antagonize or damage Serbia further." 52 This led to problems expanding the target list, particularly the authorization to attack Phase Three targets.

Among the reasons given for the extended duration of OAF are the stringent rules of engagement put in place to address the political sensitivities of NATO member states. Many compromises were necessary to maintain a consensus during the campaign. NATO's political committee and military committee ultimately determined the scope of these campaigns and exercised control over even many tactical decisions. NATO procedures allowed individual countries to place limitations on how their forces were to be used and to exercise veto authority over crucial aspects of the campaign. These procedures prevented tasked the Supreme Allied Commander Europe (SACEUR) from attacking some targets that he felt were necessary to his campaign strategy, lengthening the duration of the war in Kosovo and making a successful outcome less than certain in

\footnotetext{
${ }^{52}$ Clark, Waging Modern War, 237.
} 
the minds of many participants. Cordesman reports that "France and several other NATO countries put political limits on the number and nature of sorties flown early in the war, and ... political constraints on targeting played a major role in limiting the impact of air strikes in creating the kind of 'shock' and 'compellance' that might have led to an earlier resolution of the war." ${ }^{, 53}$ In congressional testimony shortly after the war, General Short noted that French restrictions interfered with his ability to strike important strategic targets in Belgrade and increased the danger to aircrews by preventing strikes against surface-to-air missile sites and interceptor aircraft stationed in Montenegro. ${ }^{54}$ Senior American commanders acknowledged the tension between military and political consideration stating, "As commanders, of course, we would have wanted to conduct a more rapid, overwhelming campaign with more strike power. Our desire to do so, however, had to be balanced with the need to maintain Alliance cohesion and unity. The loss of unity would have ended the campaign." 55

President Milošević's determination to hold out against Alliance military pressure made Operation Allied Force a demanding test of NATO's commitment to collective security. While ODF had lasted only 22 days, the Kosovo air campaign passed that milestone with a worsening humanitarian situation on the ground and little indication that the Serbians were ready to yield. The extended duration of the 77-day long air campaign

${ }^{53}$ Andrew Cordesman, The Lessons and Non-Lessons of The Air And Missile Campaign In Kosovo (Westport, CT: Praeger/Greenwood, 2001), 10.

${ }^{54}$ U.S. Senate, "Combined Prepared Statement of General Wesley Clark, Admiral Janes Ellis, Jr., and Lieutenant General Michael Short, of the United States European Command Before the Senate Armed Services Committee, October 21, 1999," http://armed-services.senate.gov/statemnt/1999/991021 wc.pdf.

${ }^{55}$ Ibid. 
put a great deal of strain on relations among NATO member states. Eventually, as NATO aircraft struck more Phase Two and Phase Three targets, it eventually became more difficult for the Serbians to effectively employ their military forces. With discussions among Alliance leaders favoring the imminent conduct of a ground offensive, Russia's former Prime Minister Viktor Chernomyrdin and Finnish President Ahtisaari (also acting as a representative of the EU) negotiated an agreement with Milošević to begin withdraw his forces. The withdrawal of JNA and Serbian paramilitary forces gave NATO adequate justification to stop the bombing, bringing OAF to an uneasy end in June 1999.

NATO leaders agreed to organize a peacekeeping force to oversee the Military Technical Agreement laid out in the ceasefire, just as they had done following ODF. Kosovo Force (KFOR) eventually consisted of approximately 50,000 troops, the vast majority provided by European NATO member states. A total of 39 states contributed forces to provide security within Kosovo, allowing the eventual return of refugees and the demilitarization of the Kosovo Liberation Army (KLA). Over the next several years, KFOR contributed to the extensive political and economic reform in Kosovo. NATO personnel participated in efforts to restore agricultural production, reform education, rebuild hospitals, homes, roads and related infrastructure. KFOR even supported the creation of an independent media and the reform of political parties and the judiciary. With increasing evidence of KFOR's contributions to restoring peace in the region, NATO could once again claim a central role in transatlantic security. However, it remained clear that NATO was not yet able to consistently practice collective security in a manner that suited all its members. While NATO's intervention in Kosovo obtained its 
primary objectives, the numerous difficulties encountered along the way demonstrated the need for further reform.

The Growing "Capabilities Gap"

Technological superiority over the Soviet Union and it Warsaw Pact allies had long been a priority for NATO militaries during the Cold War, and technological advances in warfare continued to remain an important as the Alliance adapted to the postCold War security environment. John Colston, then NATO's Assistant Secretary General for Defense Policy and Planning, recently remarked "The decade or so following the Cold War saw NATO embrace the goal of expanding security and stability across more of the Euro-Atlantic area by means of partnership, cooperation and ultimately, in some cases, enlargement... as the Alliance became engaged in a number of crisis-response operations further and further afield, the very nature of the military forces which Alliance operations required changed fundamentally." ${ }^{, 56}$ Achieving a consensus for collective military action among NATO member states often required military planners to assure limited casualties among combatants along with an avoidance of unnecessary collateral damage that would impact civilians. Advantages in targeting and precision attack increased the likelihood that NATO forces could fulfill the objectives of a mission under conditions acceptable its members.

NATO states struggled to remain technologically advanced in a demanding fiscal environment. In the aftermath of the Cold War, most states reduced their defense expenditures in an effort to gain a "peace-dividend" which would allow them to reduce

\footnotetext{
${ }^{56}$ John Colston, "Marrying Capabilities to Commitments," NATO Review 52, no. 2 (Summer 2004) http://www.nato.int/docu/review/2004/issue2/english/military.html.
} 
their overall spending or increase spending in other areas. The military capabilities of most European NATO member states exceeded those of other states in the region, which meant there was little cause to increase defense spending based on the need for territorial defense. These states did not feel a pressing need to improve their military capabilities, particularly if it came at the expense of ongoing economic and social reforms. High rates of defense spending were also discouraged among EU member states attempting to meet the demanding economic criteria imposed by their efforts to create a single European currency. All NATO member states, with the exception of Greece and Turkey, made large cuts in defense spending in the early 1990s. An EU Study found that the eight nations of Europe that represent eighty percent of the EU's Gross Domestic Product (GDP) reduced their defense budgets from an average of 3.2 percent of GDP to 1.9 percent during a ten-year period from 1985 to $1995 .{ }^{57}$ Defense spending in the United States declined from a high of 5.4 percent of GDP to stabilize around 3 percent of GDP by $2001 .^{58}$ Even with these reductions, the United States was spending 85 percent more each year on defense than rest of its NATO allies combined. ${ }^{59}$

Defense spending reductions constrained the ability of European NATO member states to develop new weapon systems or effectively employ existing troops and equipment in high-intensity combat operations. In order to avoid the domestic political consequences of sharp troop reductions, the majority of spending cuts affecting European

${ }^{57}$ European Union Office of External Relations, "Eurostat Statistics in Focus, Economy and Finance, no. 4298, June 1998," http://epp.eurostat.cec.eu.int/portal/4298.

${ }^{58}$ Walter Boyne, Operation Iraqi Freedom: What Went Right, What Went Wrong, and Why (New York: Forge Books, 2003), 62.

${ }^{59}$ Edgar Buckley, “Attainable Targets,” NATO Review 50, no. 3 (Fall 2002): 6. 
militaries targeted their procurement budgets. While the United States reduced defense expenditures in the early 1990s, it also shed manpower. By 2001, the United States military had half as many troops as the rest of its NATO allies combined, which allowed the United States to significantly outspend its allies significantly in the areas of modernization and procurement. ${ }^{60}$ At this time, United States was spending about $\$ 35$ billion each year on new weapons systems and on research and development, while the rest of NATO spent only around $\$ 9$ billion. ${ }^{61}$ In fact, the portion of the United States defense budget allocated for military R\&D exceeded the entire defense budget of nearly all its NATO allies.

While significant differences in capability existed among European member states, the greatest contrast could be found by comparing the military capabilities of the United States with its European allies. The United States emerged from the Cold War with professional military forces well-suited for power projection. In contrast, conscription remained in place throughout much of Europe, introducing both legal and practical obstacles to the deployment of their military forces. The demonstrated effectiveness of the United States military forces led to a belief that American military power could be applied to a greater number of foreign policy problems. The number of foreign operations conducted by American military forces grew rapidly from 19 military

\footnotetext{
${ }^{60}$ Ibid.

${ }^{61}$ Tom Lansford, A Bitter Harvest: U.S. Foreign Policy and Afghanistan (Burlington, VT: Ashgate, 2003), 100.
} 
deployments abroad in the 1980 s to 108 such deployments in the 1990 s. $^{62}$ Great Britain and France came closest to approaching the power projection capabilities of the United States, but even they were not sufficiently equipped to respond to crises outside of Europe without assistance from the United States. One analyst estimated the combined assets of all European NATO militaries suited to the role of mobile defense to be equivalent to only ten percent of that available to the United States military. ${ }^{63}$

A "capabilities gap" between the armed forces of the United States and its NATO allies manifested itself in a number of ways. Despite a large surplus of manpower in comparison with American forces, few European troops were sufficiently trained or equipped available for rapid and sustained deployment. A recent comparative study estimated that while the European members of NATO would have difficulty rapidly deploying more than six percent of their military personnel abroad for a one year period, the United States military can deploy more than sixty percent of its ground forces under the same circumstances. ${ }^{64}$ In regard to airpower, European air forces emphasized tactical rather than independent strategic air operations. European militaries also lacked the requisite sealift and airlift assets to assure a rapid and sustained deployment out-of-area. European air forces had little strategic airlift capability and relied on the United States or other foreign countries to provide long-range air transport. European navies were

\footnotetext{
${ }^{62}$ Philip Gordon and Jeremy Shapiro, Allies at War: America, Europe and the Crisis in Iraq (New York:McGraw-Hill, 2004), 57.

${ }^{63}$ British American Security Information Council, "European Defense: Not more Tanks, More Cops: BASIC Study, November 1999." http://www.basicint.org/europe/ESDP/1 199-not_more_tanks.htm.

${ }^{64}$ Michael O'Hanlon, Expanding Global Military Capacity for Humanitarian Intervention (Washington DC: Brookings Institution Press, 2003), 56.
} 
similarly lacking the necessary air defense capabilities for open ocean operations, having been equipped to operate close to their own borders and within the cover of their landbased air and ground forces.

The readiness of European forces to operate alongside those of the United States began to be called into question by the late 1990s. A 1998 Defense Science Board report pointed out, "U.S. and allied military commanders and other officials have expressed concern that with the USA's unmatched ability to invest in next-generation military technologies, it runs the risk of outpacing NATO and other allies to the point where they are incapable of operating effectively with U.S. forces on future battlefields. ${ }^{.65}$ By fielding forces that could not be efficiently coordinated and had different levels of selfprotection capabilities, NATO commanders risked being able to accomplish their objectives without unacceptably high risks of failure or fratricide. Stand-off attacks using long-range aircraft and missiles became a preferred means of projecting American power at relatively low risk. The capabilities gap meant that when compared to the American military, the military forces of virtually all European Union member states "lacked the ability to launch devastating attacks from safer distances and therefore had to pay a bigger price for launching any attack at all.",66

Growing concerns over the readiness of NATO forces on the part of American leaders prompted U.S. Secretary of Defense William Cohen to propose the creation of a targeted improvement program during a November 1998 NATO conference. This

${ }^{65}$ Bryan Bender, "U.S. Worried by Coalition 'Technology-Gap'," Jane's Defence Weekly (July 29, 1998): 8 .

${ }^{66}$ Robert Kagan, Of Paradise and Power: America and Europe in the New World Order (New York: Alfred A. Knopf, 2003), 23. 
proposal resulted in the announcement of NATO's Defense Capabilities Initiative (DCI)

the following year. According to U.S. Deputy Secretary of State Strobe Talbott, DCI was "mostly about transport and logistics, about getting forces to the area of operation and keeping them fed and equipped." ${ }^{67}$ DCI reemphasized that all NATO military forces needed to be interoperable, deployable, and sustainable, and listed fifty-eight specific projects intended to improve NATO's effectiveness. These projects were organized into five capability areas: mobility and deployability, sustainability, effective engagement, survivability, and interoperable communications. Some of these projects included standoff detection of chemical and biological weapons, airborne ground surveillance, day and night all weather air weapon systems, interoperability through increases in standardization, and enhanced capabilities against modem sea mines and torpedoes. ${ }^{68} \mathrm{~A}$ High Level Steering Group was formed within NATO to oversee DCI for a period of two years. This group was made up of senior officials from each member state and chaired by the Deputy Secretary General of NATO. The Steering group was tasked to review progress and provide guidance to each of the projects under their purview.

While DCI could attest to yielding some capability improvements, the overall result of the program was disappointing. Among the criticisms of DCI, the program was said to have "suffered from ambiguity over targets and individual national contributions." ${ }^{\circ 9}$ Other critics simply viewed it as an attempt by the United States to

\footnotetext{
${ }^{67}$ U.S. Department of State, " Secretary of State Strobe Talbott Presentation to the Royal Institute of International Affairs in London, October 7, 1999," ," (Washington D.C.: U.S. Department of State, 1999).

${ }^{68}$ NATO Office of Information and Press, "NATO Handbook."

${ }^{69}$ James Appathurai, "Closing the Capabilities Gap," NATO Review 50 no. 3 (Fall 2002): 4.
} 
convince its European allies to terminate domestic weapons systems program and purchase American equipment and munitions. By the summer of 2001, the Steering Group reported that Alliance members were spending only half of what was needed to meet the existing force goals. NATO's Secretary General admonished those governments that failed to follow through on the commitments of DCI, stating "for the Europeans there is a clear message...if a crisis comes along, the capability will not be there. $^{, 70}$

NATO operations in the Balkans provided clear evidence that combined military operations also left much to be desired in the minds of many military leaders. In the months following OAF, U.S. Secretary of Defense Cohen and General Shelton, the Chairman of the Joint Chiefs of Staff, called on NATO leaders to overcome "glaring weaknesses in command, control, communications, computers and intelligence."71 Many European aircraft were operating with insecure communications systems or systems that were incompatible with those of the U.S. military. Gen. John Jumper, then Commander in Chief, U.S. Air Forces, Europe testified to the House Armed Services Committee that these shortcomings jeopardized operational security throughout OAF. General Jumper relayed incidents of target and aircraft position data being intercepted by Serb commanders who were able to monitor NATO communications and adjusted their plans

\footnotetext{
${ }^{70}$ Michael Gordon, “Armies of Europe Failing to Meet Goals, Sapping NATO,” The New' York Times, June 7, 2001.

${ }^{71}$ U.S. Department of Defense, "Transcript: Cohen and Shelton News Conference at NATO Ministers' Conference, September 22, 1999," http://www.usembassy-israel.org.il/publish/press/defence/archive/ 1999/september/dd 1927.htm.
} 
accordingly. ${ }^{72}$ European air forces were of limited use to campaign planners since few of their aircraft could fly at night or in bad weather. Some night-capable aircraft, such as Royal Netherlands Air Force F-16s, lacked the more accurate munitions needed for sensitive targets. $^{73}$

The troubling lessons of Kosovo were noted on both sides of the Atlantic. In a fall 1999 address to The British Royal Institute of International Affairs, U.S. Deputy Secretary of State Strobe Talbott pointed out the growing dissatisfaction with combined operations, stating "Many Americans are saying never again should the United States have to fly the lion's share of the risky missions in a NATO operation and foot by far the largest bill..74 General Naumann, then Chairman of NATO's Military Committee, testified to the U.S. Senate Armed Services Committee, “As a European, I am ashamed we have to ask for American help to deal with something as small as Kosovo."75 Despite a general recognition of the problem, there was little expectation that European governments would commit sufficient resources to close the capabilities gap. A German defense analyst commented soon after OAF, "The situation would be hilarious if it weren't so tragic...We come out of the Washington and Cologne NATO and [EU]

${ }^{72}$ U.S. House of Representatives, "Military Readiness Subcommittee Hearing on the Readiness Impact of Operations in Kosovo: Problems Encountered, Lessons Learned, and Reconstitution, October 26, 1999" http://www.house.gov/hasc/testimony/l06thcongress/99-10-26jumper.htm.

${ }^{73}$ John Peters, et al., European Contributions to Operation Allied Force: Implications for Transatlantic Cooperation (Santa Monica, CA: RAND, 2001), 73.

${ }^{74}$ Nicola Butler, "NATO Ministers Fudge the Essentials," Disarmament Diplomacy 42 (December 1999). http://www.acronym.org.uk/dd/dd42/42nato.htm.

${ }^{75}$ U.S. Senate. "United States Senate Committee on Armed Services Testimony on the Lessons Learned from the Military Operations Conducted as Part of Operation Allied Force, and Associated Relief Operations, with Respect to Kosovo. November 3, 1999," http://armed-services.senate.gov/hearings/1999/ c991103.htm. 
meetings with strong statements of how Europe has learned its lesson from Kosovo, but the defense budget shows that we haven't learned a thing.,"76

Growing concerns over interoperability and burden sharing were also prevalent among American representatives. While all NATO member states expressed political solidarity through their concurrence with the decision to initiate OAF, only thirteen states participated in the air campaign itself. Many European air forces made important contributions, to include numerous strike missions by British and French aircrews and the considerable role played by German and Italian aircrews in the Suppression of Enemy Air Defenses (SEAD). However, the limited availability and capability of European aircraft meant that American aircrews once again dominated the overall conduct of this operation. Air refueling missions, electronic warfare missions, and the most demanding precision attack sorties were reserved for American aircrews. The United States provided more than seventy percent of the aircraft and munitions utilized during the war. The American military's central role in the air campaign resulted in the United States paying more toward the cost of the operation that all of its NATO allies combined. The United States eventually paid sixty percent of the $\$ 5$ billion air campaign along with an anticipated annual cost of $\$ 3.5$ billion to maintain 7,000 troops in Kosovo to participate in KFOR. ${ }^{77}$ The high cost to the United States led some American policymakers to renew questions about whether the benefits of multilateral operations outweighed their cost and complexity. American lessons regarding the conduct of OAF included the need

\footnotetext{
${ }^{76}$ Douglas Barrie and Jack Hoschouer, "Bundeswehr's Unclear Role Underlies Budget Conflicts," Defense News, August 9, 1999.

${ }^{77}$ Tom Lansford. All For One: Terrorism, NATO and the United States ( Burlington, VT: Ashgate, 2002), 50.
} 
to improve the regime's organizational rules and procedures for conducting such a campaign. General Clark observed a general agreement with one NATO defense minister's suggestion that the fundamental lesson was of OAF was that "we never want to do this again."78 The tensions over Kosovo had stressed relations among member states as well as its regional partners, including Russia. The unease evident throughout the campaign led NATO leaders to propose another strategic review to clarify the Alliance's commitment to collective security.

The 1999 rewrite of NATO's Security Concept emphasized the need for the Alliance to continue pursue the capabilities needed to permit the Alliance to extend its commitment to collective security. Secretary General Solana emphasized NATO's commitment to both collective defense and collective security in a speech during the 1999 Rome Summit, "This adaptation will keep NATO strong and able to function as a coherent politico-military Alliance in a very different security environment. NATO's internal adaptation will allow us to provide for our collective defense and contribute to collective security."79 The 1999 Security Concept found that Alliance members shared a common interest in regional security which was threatened by "the appearance of complex new risks to Euro-Atlantic peace and stability, including oppression, ethnic conflict, economic distress, the collapse of political order, and the proliferation of

\footnotetext{
${ }^{78}$ Clark, Waging Modern War, 417.

${ }^{79}$ NATO Office of Information and Press, "NATO: Its 50th Anniversary -The Washington Summit - The Next Century, January 25, 1999," http://www.Nato.Int/Docu/Speech/1999/S990125a.htm.
} 
weapons of mass destruction." ${ }^{80}$ In order to counter these risks, the 1999 Security

Concept called for NATO to adopt non-Article Five operations such as "crisis

management" and "crisis response operations" as core missions.

The revised Security Concept recognized that the Alliance's emphasis on crisis management would require the development of new capabilities and continued organizational reform. NATO leaders called for member states to strive to develop capabilities that would give the Alliance "the ability to build-up larger, adequately equipped and trained forces, in a timely manner and to a level able to fulfill the full range of Alliance missions." ${ }^{\prime 81}$ The anticipated increase in out-of-area missions would require the allies to support the organization of rapid reaction forces and to increase their combined power projection capabilities. These reforms fueled expectations among some observers that the Alliance would soon be better prepared to cope with the challenges of a new century, while more pessimistic views recognized this as simply another case of political rhetoric exceeding the real commitment of member states to alter the status quo.

The European Union as a Rival Security Regime

NATO and the EC coexisted with relative ease during the Cold War due to their clear division of responsibilities. NATO provided a link with American military power in an effort to counter the threat of a Soviet invasion, while the EC helped its members become more prosperous through economic integration. Uncertainties regarding the continued American commitment to European security and the broadening of the EU's

\footnotetext{
${ }^{80}$ NATO Office of Information and Press, "The Alliance's Strategic Concept," http://www.Nato.int/Docu/ Pr/1999/P99-065e.htm.

${ }^{81}$ Ibid.
} 
mandate into new issue areas challenged the historical roles of both regimes. As Norman Ray, NATO's Assistant Secretary General for Defense Support, would later observe "As the European allies seek to develop a European Security and Defense Identity (ESDI), the old division of labor - where NATO took care of European security while the European institutions focused mainly on economic integration - no longer reflects transatlantic realities." 82 As European integration progressed during the 1990s, American and European leaders struggled to form new expectations for both regimes.

The 1991 Maastrich Treaty officially established the European Union, with existing progress toward economic integration representing one "pillar" in the process of bringing about closer relations between member states. The economic pillar was strengthened with additional agreements bringing the EU closer to establishing a single currency. A second pillar emerging from the treaty was termed Justice and Home Affairs and consisted of consisting of efforts to standardize policies on social issues such as asylum, immigration, drugs and terrorism. The third and final pillar designated the WEU as the defense component of the EU and formalized the goal of establishing a Common Foreign and Security Policy. The text of the treaty stated that this common policy "shall include all questions related to the security of the union, including the eventual framing of a common defense policy, which might in time lead to a common defense." ${ }^{, 83}$ Advocates of CFSP saw the need to increase coordination in foreign policy areas and reduce Europe's dependence on the United States in security matters. Little consensus

\footnotetext{
${ }^{82}$ Norman Ray, "Security Cooperation and the New NATO," 13.

${ }^{83}$ European Union Office of External Relations, "Treaty on European Union,” http://europa.eu.int/en/ $\mathrm{record} / \mathrm{mt} /$ top.html.
} 
existed among Europeans beyond voicing the inevitable necessity for greater cooperation on security matters in the future. Europeans were divided among alternate visions of pursuing a military capability fully independent of NATO, as French leaders had long desired, or more moderate British and German proposals to pursue a European Security and Defense Identity within NATO.

A common rationale for ESDI emphasized the necessity of an alternative security structure in the event that the United States chose not to honor its commitment to defend Europe. One scholar notes, "The European countries, led by France, demanded a capacity for European action because they feared abandonment by America and therefore they needed an alternative." 84 The United States maintained security commitments around the globe and could be expected to shift its focus away from Europe as NATO's victory over the Soviet Union became more certain. European concerns of abandonment by its North American allies were heightened when Canada announced in February 1992 that it would withdraw its standing forces from Europe. Public debate within the United States over the cost of stationing American troops in Europe added to the unease of many Europeans. Despite these concerns, German leaders advocated a cautious approach to ESDI that would allow EU members to "search for greater convergence or identity of interests while not changing the basic political and military structure of the [NATO] alliance." ${ }^{85}$ This position was consistent with the commitments made in NATO's 1991

\footnotetext{
${ }^{84}$ Hanns Maull, "Strategic Outlook: Compatibilities and Incompatibilities," in NATO and Collective Security, ed. Michael Brenner (New York: St. Martin's Press, 1998), 235.

${ }^{85}$ Peter Schmidt, "ESDI: A German Analysis," in Reforging the Trans-Atlantic Relationship, ed. Charles Barry (Washington, DC: National Defense University Press, 1996), 37.
} 
Security Concept to maintain NATO as "the essential forum for consultation among the allies" despite the growing contribution of other regimes such as the EU and CSCE. ${ }^{86}$

An improvement in relations among large European states and the emergence of a European identity had a number of practical defense implications. France had been particularly willing to adopt an integrated European approach toward security and actively promoted the organization of a robust, independent European military force. France kept its distance from NATO and other cooperative security arrangements during the Cold War in order to preserve its ability to look after its own security and its interest in its former colonies. French leaders felt the need for changes in their security policies following the end of the Cold War, changing their perception of vital interests from national defense to European defense. One scholar characterized the transformation of French security and defense policies since the end of the Cold War as "so radical that one can assimilate it to a shift in nation-state identity meaning the Europeanization of French exceptionalism. ${ }^{, 87}$ French reforms included the professionalization of its military forces, a new emphasis on conventional forces over nuclear forces, and the increased deployment of forces within Europe rather than in post-colonial Africa. Changes in doctrine and arms procurement were also made to favor multinational programs. This reversal from French policies of national independence toward greater military cooperation among EU member states would aid the efforts to establish a CFSP.

\footnotetext{
${ }^{86}$ NATO Office of Information and Press, "The Alliance's Security Concept Agreed by the Heads of State and Governments Participating in the Meeting of the North Atlantic Council, November 8, 1991," http://www.nato.int/docu/basictxt/b911108a.htm.

${ }^{87}$ Bastien Irondelle, "Europeanization without the European Union? French military reforms 1991-96," Journal of European Public Policy 10, no 2 (April 2003): 219.
} 
The EU's 1992 Petersberg Declaration stated that WEU forces would continue to be allocated to the collective defense of NATO while developing a capability to conduct independent operations. EU member states agreed "Military units of WEU member states acting under the authority of WEU could be employed for humanitarian and rescue tasks; peacekeeping tasks; tasks of combat forces in crisis management, including peacemaking. ${ }^{\Perp 88}$ American suspicions regarding EU initiatives have at times run counter to European efforts to develop new capabilities. As one pair of scholars point out, "Washington has consistently urged its European allies to do more. But it has just as consistently warned them not to do so in ways that challenged NATO or in any other way weakened Alliance unity." ${ }^{89}$ American leaders were initially critical of attempts by EU member states to form multinational forces to engage in the tasks identified in the Petersberg Declaration without U.S. participation. The Franco-German Eurocorps was established in May 1992, with the assurance by both French and German officials that the corps would complement rather than duplicate NATO units. As a concession to American concerns, Germany and France agreed in December 1992 to place the Eurocorps under NATO command in the event of a crisis.

The United States supported ESDI as a means of increasing the military capabilities of NATO member states, but emphasized the necessity of pursuing European military reform within NATO. President Clinton and his senior advisors promoted the concept of "separable but not separate" European capabilities and successfully gained the

\footnotetext{
${ }^{88}$ Western European Union, "Petersberg Declaration, June 19, 1992," http://www.weu.int/documents/ 920619peten.pdf.

${ }^{89}$ Ivo Daalder and James Goldgeier, "Putting Europe First," Survival 43, no. 1 (2001): 79.
} 
endorsement of this approach to an ESDI among its European allies at a 1994 NATO summit. ${ }^{90}$ U.S. State Department officials emphasized NATO's primacy, making it clear that the United States "would not want to see an ESDI that comes into being first within NATO but then grows out of NATO and finally grows away from NATO, since that would lead to an ESDI that initially duplicates but that could eventually compete with NATO."91

NATO's experience in ODF also affected the course of ESDI. The size and advanced technology of American military forces had made them essential to the conduct of ODF. Most NATO militaries had difficulty sustaining combat forces outside of their own borders. In contrast, American military forces were almost exclusively depended upon to provide many of the high-technology capabilities required for such a campaign, including air transport, satellite intelligence, and electronic jamming. American aircraft flew two-thirds of all sorties during ODF, primarily because allied air forces lacked the precision strike capabilities demanded by the campaign planners or were otherwise less suited to the missions. While recognizing that ODF could not have been conducted without American participation, European leaders did not want to give the United States veto power over future operations. American reluctance to deploy ground troops to the Balkans in advance of a peace agreement had made it more difficult for the Alliance to act. European alliance members were willing to commit ground troops, but required access to NATO assets for command and control of their forces. The Alliance needed the

\footnotetext{
${ }^{90}$ Margarita Assenova, The Debate on NATO's Evolution: A Report of the CSIS Eastern Europe Project. (Washington DC: Center for Strategic and International Studies, 2003), 28.

${ }^{91}$ Stobe Talbott, "Presentation to the Royal Institute of International Affairs in London, October 7, 1999."
} 
ability to support operations involving a subset of member states when universal participation was unlikely. By creating an alternative means of employing forces, all member states could share the benefits of having a particular threat brought under control without having to deploy forces.

An important organizational reform toward the creation of this capability within NATO was the organization of Combined Joint Task Forces (CJTFs). The CJTF concept was first proposed by U.S Secretary of Defense Les Aspin at a meeting of NATO defense ministers in October 1993 and was endorsed by Alliance members at the Brussels summit the following year. The CJTF concept addressed the organization and command of multinational forces from multiple military services. These forces would be "generated and tailored primarily, but not exclusively, for military operations not involving the defense of Alliance territory, such as humanitarian relief and peacekeeping. It provides a flexible and efficient means whereby the Alliance can generate rapidly deployable forces with appropriate command and control arrangements." 92 The existence of CJTFs meant that neither the United States nor any other single state would have to participate for such operations to take place, although all Alliance members would still have to agree to initiate the mission.

The creation of CJTFs also addressed some of the challenges arising from an increasing interest in ESDI among European leaders. American leaders were anxious to support European efforts to develop more capable military forces, but opposed any plans for CFSP that might decouple the United States from Europe, duplicate NATO structures

\footnotetext{
${ }^{92}$ NATO Office of Information and Press, NATO Fact Sheet: The Combined and Joint Task Force Concept, August 8, 2000 (Brussels: NATO Office of Information and Press, 2000).
} 
and capabilities, or discriminate against NATO members not in the European Union or WEU. ${ }^{93}$ The CJTF concept satisfied both American and European leaders by providing a flexible framework for organizing military forces under circumstances that did not necessarily involve the entire Alliance. Under the agreements formed at NATO's 1994 Brussels summit and 1996 Berlin summit, CJTFs could serve under the control of either NATO's integrated military structure or the WEU, depending on which member states chose to participate in an operation. In practice, NATO assets included logistics, transport, and support functions that could be utilized for a range of military operations involving any number of member states. CJTFs provided enhanced flexibility with respect to the use of troops and resources, making it easier for Alliance members to agree to conduct collective security operations in the future. CJTFs could be formed without the participation of all NATO member states and would be open to the participation of non-member states. As a result, CJTFs might take the form of a "NATO-only" CJTF solely consisting of NATO member states, a "NATO-plus" CJTF augmented by forces from non-member states, or even a "NATO-plus-minus" CJTF consisting of a subset of NATO member states operating along side forces from non-member states. ${ }^{94}$

In contrast to ad-hoc coalitions, CJTFs would benefit from regular exercises held among likely participants in advance of any operational deployment. These exercises involved Alliance assets and allowed standardized procedures to be developed that could be tailored to specific contingencies. CJTF procedures were developed in a number of

\footnotetext{
${ }^{93}$ William Drozdiak, "U.S. Tepid on European Defense Plan: American Stance Vexed EU Leaders" The Washington Post, March 7, 2000.

${ }^{94}$ Charles Barry, "NATO's Combined Joint Task Forces in Theory and. Practice," Survival 36, no. 3 (Spring 1996): 92-3.
} 
exercises including Exercise Allied Effort in November 1997 and Exercise Strong

Resolve in March 1998. The experiences gained from these exercises as well as operations in the Balkans resulted in the NAC's decision in 1999 to bring CJTFs into operation, a process that would continue to take several years to complete. CJTF staffs were organized within NATO headquarters to serve as the nucleus for future operations. Once operational, these "headquarters 'nuclei' join with 'augmentation' modules and 'support' modules appropriate to a particular operation to form a CJTF headquarters specifically structured to meet the requirements of the operation in question."95

A renewed debate over the division of responsibilities between NATO and the EU followed the 1998 Saint-Malo summit between British Prime Minister Blair and French President Chirac. A joint declaration from the summit emphasized the need to reconsider the integration of the WEU and EU and establish an autonomous security role for the EU. The following year, the European Council issued a statement that "the Union must have the capacity for autonomous action, backed up by credible military forces, the means to decide to use them, and a readiness to do so, in order to respond to international crises without prejudice to actions by NATO." 96 American leaders expressed concern that the EU intended to conduct regional crisis management and peacekeeping operations independently, limiting NATO to Article Five collective defense operations. After extensive lobbying by American and British officials, the European Council brought their position more in line with agreements formed at the Saint-Malo summit. Under this

\footnotetext{
${ }^{95}$ NATO Office of Information and Press, "NATO Handbook."

${ }^{96}$ European Union Office of External Relations, Presidency Conclusions, Cologne European Council, June 3-4, 1999 (Brussels: European Union, 1999).
} 
approach, any autonomous capability for the EU would be exercised after consulting with NATO, limiting the EU "to take decisions and approve military action where the [NATO] Alliance as a whole is not engaged." 97

The overreliance on American planning and capabilities during OAF once again energized efforts to establish an effective ESDI. The EU appointed former NATO Secretary General Javier Solana to be the High Representative for Common Foreign and Security Policy in 1999. Solana soon began establishing the requirements for an allEuropean military force and announced his goals for such a force in the months following OAF. The Headline Goal for a European Rapid Reaction Force (ERRF) was to have between 50,000 and 60,000 troops that could be deployable within sixty days and sustainable for a year. Observers soon pointed out that EU member states needed to prepare a force of 200,000 troops to allow for rotation and with EU defense budgets declining, and were doubtful that the goal could be reached. ${ }^{98}$ The size of the force fueled American concerns regarding the impact on military forces allocated to future NATO contingencies. British and German officials attempted to reassure the United States by clarifying that they regarded the ERRF to be an as an adjunct to NATO, to be used when NATO chose not to be involved in an operation rather than an independent European Army.

The EU's 1999 Helsinki conference resulted in further initiatives to provide the EU with access to a more credible military force. EU leaders agreed at this conference to

\footnotetext{
${ }^{97}$ Embassy of France to United States, "Franco-British Summit Joint Declaration on European Defence, Saint-Malo, December 4, 1998, http://www.info-france.org/news/statmnts/pr/stmalo.htm.

${ }^{98}$ Assenova, The Debate on NATO's Evolution, 30.
} 
establish a number of committees and related organizations to serve as the necessary infrastructure for the organization and deployment of military forces for EU-led operations. Contemporary observers noted, "Unlike NATO, the WEU has no peacetime supreme commander, no peacetime military headquarters, and no standing command and control structure. Without infrastructure, training, and major exercises, the WEU has no capability to project power or promote stability in the event of a crisis threatening its member states." 99 In an effort to avoid the duplication of capabilities, NATO leaders once again agreed to give EU member states access to NATO assets as well as "the further adaptation of NATO's defense planning system to incorporate more comprehensively the availability of forces for EU-led operations." ${ }^{100}$ These agreements allowed the EU to create new political and military bodies, including a Political and Security Committee, a Military Committee composed of national defense chiefs, assisted by a Military Staff with various functional experts.

By the fall of 2001, EU High Representative Javier Solana's increasing diplomatic profile in the Balkans and the increasing competence of EU security committees justified including the EU in an extension of NATO's peacekeeping responsibilities into Macedonia. Operation Essential Harvest involved the deployment of 3,500 NATO troops to Macedonia for thirty days to collect weapons and monitor a ceasefire between the Macedonian government and Albanian minorities. The EU

\footnotetext{
${ }^{99}$ Kay, NATO and the Future of European Security, 130.

${ }^{100}$ NATO Office of Information and Press, "Washington Summit Communique: An Alliance for the $21^{\text {st }}$ Century, April 24, 1999," http://www.nato.int/docu/pr/1999/p99-064e.htm.
} 
provided economic incentives to promote compliance with the weapon collection efforts and organized a follow-on policing mission following the end of the month-long weapons collection effort. The partnership between the EU and NATO in Macedonia demonstrated the growing role of the EU in regional security efforts and the first tangible demonstration of Europe's reduced dependence on the United States.

Regime Analysis: Post-Cold War NATO

Many realist scholars were initially skeptical about NATO retaining a central role in European security after the Cold War. Following the collapse of the Soviet Union, Waltz joined other realists in concluding that NATO must either disappear or be reorganized around a new balance of power. In an essay shortly after the breakup of the Soviet Union, Waltz asks, "How can an alliance endure in the absence of a worthy opponent?" concluding "NATO's days are not numbered, but its years are."101

Mearsheimer also predicted a breakdown in the unity among NATO members following the end of the Cold War. In a 1990 article he states, "It is the Soviet threat that holds NATO together. Take away that offensive threat and the United States is likely to abandon the Continent, whereupon the defensive alliance it headed for forty years may disintegrate." ${ }^{\prime 02}$ He anticipated a weakening of American and Soviet influence in Europe resulting in a multipolar Europe that is more prone to internal conflict. While America's engagement through NATO "mitigated the effect of anarchy on Western

\footnotetext{
${ }^{101}$ Kenneth Waltz, "The Emerging Structure of International Politics Brown," in The Perils of Anarchy: Contemporary Realism and International Security, eds. Michael Brown, Sean Lynn-Jones, and Steven Miller (Cambridge, MA: MIT Press, 1995), 73-4.

102 John Mearsheimer, "Back to the Future: Instability in Europe after the Cold War," International Security 15, no. 1 (Summer 1990): 49.
} 
Democracies and facilitated cooperation among them," the decline of the Soviet power could be expected to remove the incentive for continued cooperation. ${ }^{103}$

When confronted with NATO's continued existence later in the 1990s, realists found that NATO persisted due of its role as a vehicle for American hegemony. According to Waltz, NATO's persistence embodies "America's folly" of continuing to dominate the foreign and military policies of European states. ${ }^{104}$ American hegemonic power therefore became the source of NATO's persistence rather than the cause of its decline. The relative power of the United States grew following the collapse of Soviet Union and substantial reductions in defense spending in Europe. Waltz's analysis reveals that a changing balance of power resulted in undisputed American hegemony, and NATO has become a vehicle for the promotion of American interests within Europe. Mastanduno similarly characterizes NATO's persistence as a result of its compatibility with American hegemony. He argues that the United States has followed a policy of preserving NATO and the multilateral cooperation this entails, in part, because it wishes to keep the potential regional powers of Germany and Russia, which it has engaged through NATO programs, from challenging American preponderance. ${ }^{105}$

A second line of reasoning recognizes that the dissolution of the Soviet Union did not ensure the reemergence of a Russian empire or signify the end of disagreements among states in the region. Many realists emphasized the need to retain the Alliance as a

\footnotetext{
${ }^{103}$ Ibid, 45.

${ }^{104}$ Kenneth Waltz, "Structural Realism After the Cold War," International Security 25 (Summer 2000): 12.

${ }^{105}$ Michael Mastanduno, "Preserving the Unipolar Moment," International Security 21, no. 4 (Spring 1997): 49-88.
} 
hedge against a resurgence of Soviet power. There were considerable fears that the collapse of the Soviet Union would not be any more peaceful than earlier periods of imperial collapse, such as those that followed the end of the Austro-Hungarian Empire or the Ottoman Empire. Prominent realists favoring continued American support for NATO included Henry Kissinger, Zbigniew Brzezinski, and then U. S. Senate Foreign Relations Chair Jesse Helms. Under Secretary of Defense Walter Slocombe summarizes the views of these NATO supporters, stating "The course that we are seeking for Russia foresees an optimistic outcome, and maintains an optimistic outlook. But we are not naive about Russia, and we are acutely conscious of the dangers, of the hard lessons of history...An integral part of our pragmatic partnership policy for Russia is that we continue to remain strong, so we have a military hedge against whatever might come." 106 These realists felt that the United States should remain engaged in Europe through NATO in order to have the best opportunity to assure a peaceful future for the region.

This perspective also values NATO as a hedge against a reversal of the dominant pattern of peaceful relations among European states since the end of World War Two. Kay sees a need to maintain NATO "to enhance security by expanding the Alliance into Central and Eastern Europe. NATO enlargement would consolidate the new status quo after the Cold War by reassuring Germany's neighbors about its growing power and increasing the West's deterrence capacity against Russia."107 In this way, NATO's persistence and expansion into new roles is once again viewed as consistent with the

\footnotetext{
${ }^{106}$ U.S. Department of Defense, "Honorable Walter B. Slocombe, Under Secretary Of Defense For Policy Remarks To The Atlantic Council On European Security Washington, D.C. June 14, 1996," http://www.Dod.Mil/Releases/1996/B062096_Bt371-96.html.

${ }^{107}$ Kay, NATO and the Future of European Security, 6.
} 
desire of American leaders to keep the United States at the center of a European security dialogue.

This research provides substantial evidence supporting a power-based approach to regime analysis in the actions of the United States as it sought to retain its influence over European security affairs. Many practical examples of American leadership can be found in the introduction of collective security tasks in the post-Cold War era. NATO's Partnership for Peace program, its introduction of Combined Joint Task Forces, and the Alliance's approach to expansion were all largely guided by American diplomacy. Many of these initiatives served the dual purposes of aiding NATO's transition into the practice of collective security while preserving the Alliance's mandate in light of further European integration. The United States consistently strove to ensure NATO's primacy as the EU increasingly expanded its role in European security. The renewed credibility of the Alliance in the 1990s owes much to the commitment of American leaders to remain engaged in Europe and encourage its allies to contribute to the collective resolution of common security challenges.

The United States played a decisive role in planning and executing the Alliance's successful military interventions in Bosnia-Herzegovina and Kosovo. The determined leadership of the United States was of inestimable value during these interventions, in many ways justifying U.S. Secretary of State Madeline Albright's designation of the United States as the "indispensable power" with unique capabilities and 
responsibilities. ${ }^{108}$ American leadership enabled NATO to take a more active role in bringing about an end to the fighting in the region. However, the a pattern of American dominance in the conduct of military interventions was also emerging, and European leaders increasingly came to view the United States as having an insufficient regard for the interests and concerns of their NATO allies.

The dominant role of the United States was clear in NATO's first military intervention in the Balkans. American reluctance to deploy ground troops to the Balkans in advance of a peace agreement had initially made it more difficult for the Alliance to act. Early efforts by NATO and the WEU to decrease the violence in the region through the conduct of Operation Sharp Guard were unilaterally abandoned by United States. As emphasized in Mueller's research, American leaders held a contrasting view of the conflict in Bosnia-Herzegovina that viewed the Bosnian Serbs as aggressors and argued for a peacemaking strategy aimed at compelling the Serbs to agree to a political settlement. This difference in the perception of the causes of the conflict contributed to a delay in collective action until European allies eventually adopted the American perspective. Once NATO agreed to an approach consistent with the preferences of the United States, American diplomats played a leading role in negotiations with Serbian leaders and American airpower provided the means to carry out an effective air campaign. While recognizing that the military and diplomatic strength of the United States made it easier for the Alliance to act in any manner, some participants concluded

\footnotetext{
${ }^{108}$ Charles Kupchan, et al, Power in Transition: The Peaceful Change of International Order (New York: United Nations University Press, 2001), 94.
} 
that during ODF "NATO had been manipulated to allow the U.S. to conduct its own unilateral policy in the Balkans." 109

The pattern of American dominance in NATO operations was also apparent in the conduct of OAF. The United States led a Contact Group joined by Great Britain, France, Germany, Italy, and Russia continued to negotiate with both Serbian and Kosovar Albanian representatives through the spring of 1999. Many European policymakers were opposed to the idea of threatening to use force against the Serbian military, while French and German officials felt force should only be used in conjunction with a UN mandate. American diplomats advocated for a repeat of the airstrikes that had coerced Serbia into earlier negotiations, and lobbied for the Alliance to act in spite of Russian obstruction within the UN Security Council. OAF was conducted as a combined NATO military campaign following an operational plan primarily laid out by American personnel serving on the SHAPE and EUCOM staffs. American planners identified virtually all the targets and limited access to target information. One observer notes a sharp distinction between American and European lessons learned from OAF, finding "Whereas many in Europe saw the Kosovo air campaign as excessively dominated by the United States and American generals, most Americans - particularly within the military saw just the opposite: excessive European meddling with French politicians and European lawyers interfering with efficient targeting and bombing runs, and compromising operational security." 110 Senior American officers commanding operations in the Balkans had

\footnotetext{
${ }^{109}$ BBC News, “Allies and Lies, June 22, 2001,” http://news.bbc.co.uk/1/hi/audiovideo/programmes/ correspondent/I390536.stm

${ }^{110}$ Philip Gordon, “NATO After 11 September," Survival 42, no. 4 (Winter 2001-2002): 97.
} 
expressed a good deal of frustration with the oversight provided by the NAC. General Shelton, the U.S. Chairman of the Joint Chiefs of Staff testified to the Senate Armed Services Committee soon after OAF, "Working within the NATO alliance unduly constrained U.S. military forces from getting the job done quickly and effectively."111 In contrast, French Foreign Minister Hubert Vedrine found that NATO's experience in OAF confirmed the status of the United States as a "hyperpower" and made it all the more necessary that a united Europe strive to "constitute a factor of equilibrium.". 12 The differences in these perspectives would have significant implications for the Alliance's attempts to extend the practice of collective security outside of Europe.

An organization-based approach to regime analysis offers its own rationale for why regimes persist even after there are changes to the perceived threat or distribution of power. International organizations are not static bodies, and have demonstrated the ability to be more adept at accommodating change than many realists recognize. Duffield credits the organizational characteristics of NATO with giving the Alliance a central role in transatlantic security. He states, "NATO's institutional character has probably contributed to the Alliance's persistence. ... [these] supranational bodies and the individuals who head them have almost certainly helped the Alliance to adapt to changing external circumstances, by defining new tasks, identifying ways to achieve

\footnotetext{
${ }^{111}$ U.S. Senate, "Joint Statement to Senate Armed Services Committee by Secretary of Defense William S. Cohen and Gen. Henry H. Shelton on the Kosovo After Action Review, Oct. 14, 1999" http://armedservices.senate.gove/statemnt/1999/991014wc.pdf.

112 “The Ageing Alliance," The Economist (October 23, 1999): 10
} 
them, forging compromises, and otherwise providing leadership." 113 NATO provided access to time-tested rules and procedures that allowed member states to gain access to capabilities well-suited to emerging security challenges.

Organization-based approaches to regime analysis emphasize that regime change can often be more easily accommodated by evolving current organizations rather creating new ones. Neoliberal institutionalists point out that new organizations entail start up costs and states have no way of recouping the sunk costs of existing organizations. Even organizational shells have value, and can serve as a vehicle for regime change. As Betts states, "Shells are far from useless-they can maintain the base from which remobilization and coordination can be accomplished in a shorter time than if they had to be accomplished from scratch."114 In the case of NATO, McCalla observes, the allies "spent forty-five years learning how to work as a long-term coalition through a sophisticated political and military structure...Developing new institutions or consultative frameworks entails start-up costs; NATO's appeal is that these costs already have been paid."15 The persistence of international organizations can be attributed to the unwillingness of member states to give up the current and future benefits of regimes, which may lead to the persistence of organizations whose initial utility has called into question by changes in the international environment.

\footnotetext{
${ }^{113}$ John Duffield, "The North Atlantic Treaty Organization and Alliance Theory," in Explaining International Relations since 1945, ed. Ngaire Woods (Oxford: Oxford University Press, 1996), 343-345.

${ }^{114}$ Richard Betts, "Systems of Peace as Causes of War? Collective Security, Arms Control, and the New Europe," in Coping with Complexity in the International System, eds. Jack Snyder and Robert Jervis. (Boulder, CO: Westview Press, 1993), 272.

${ }^{115}$ Robert McCalla, "NATO's Persistence After The Cold War," International Organization 50, no. 3 (Summer 1996): 464 .
} 
Institutionalists point out the numerous ways that NATO evolved to serve many interrelated security functions beyond collective defense. McCalla notes, "The wider the range of functions that an alliance fulfills beyond its core defense function, the less responsive it will be to changes in the threats it faces and the more likely it is to be transformed in purpose as its external environment changes." 116 NATO's internal organizations created effective procedures that provided military, political, and economic benefits to members while preserving their sovereignty. These procedures addressed force planning and funding, along with operational considerations such as combined command arrangements and integrated air and land defenses. They also resulted in common equipment standards as well as compatible procedures for training and logistics. Allied states arranged to share communication networks, command and administrative facilities, as well as military equipment. These analysts argue that NATO organizations provided unique contributions to regional security that the allies would be unwise to abandon.

The rules and procedures of NATO organizations facilitated the practice of both collective defense and collective security during this period. The NAC preserved internal bodies promoting the security commitments among member while introducing new initiatives intended to preserve strengthening ties to emerging democracies. The consultation, planning and command functions associated with defending Western Europe from a potential Soviet invasion made NATO valuable source for the preparation and conduct of combined military operations. NATO succeeded in restoring peace to the

\footnotetext{
${ }^{116}$ Ibid, 470.
} 
Balkans after similar attempts by other international organizations failed. The Alliance's success in these endeavors was due to in great part to the contributions of legacy organizational bodies that promoted consensus and effectively coordinated the activities of member state military forces.

When compared to the European Union, NATO remained an intergovernmental organization with little impact on the sovereignty of its member states. Disputes were more commonly resolved among NATO member states than through the delegation of authority to supranational bodies. As during the Cold War, procedures dictating decision-making via consensus and weak enforcement measures prevented NATO organizations from independently constraining member state behavior. NATO nonetheless proved to be the most capable international security organization in the region, influencing both member and nonmember states due to the effectiveness of Alliance's consultative bodies and the credibility of the Alliance's mutual security guarantee.

A norm-based approach to regime analysis suggests that presence of shared values and a common identity among member states contributed to the ongoing commitment of member states to the Alliance throughout this era. In the aftermath of the Cold War, NATO faced speculation that it would not survive the disappearance of its enemy. Harries concludes, "The political 'West' is not a natural construct but a highly artificial one. It took the presence of a life-threatening, overtly hostile 'East' to bring it into existence and to maintain its unity. It is extremely doubtful whether it can now 
survive the disappearance of that enemy." 117 Without the Soviet threat, one key element of identity was removed. However, the Alliance retained its unity due to a sincere commitment to expanding the influence of shared values throughout the region. The allies continued to associate NATO with shared interests and values that served as the basis for continued cooperation. The peaceful emergence of democracy in Central and Eastern Europe and the necessity of limiting ethnic conflict in the Balkans did not simply affect European members of NATO, as all the allies had vested interests in the outcome.

NATO's efforts to respond to a changing international security environment are consistent with constructivist portrayals of the ongoing co-constitution of identity and interests. The changes in the transatlantic security environment prompted NATO to expand its membership and adopt elements of a collective security regime. Central and Eastern European states were welcomed into the Alliance as they demonstrated their commitment to democracy and peaceful relations with neighboring states. NATO organized and deployed military forces to bring an end to outbreaks of violence threatening regional stability in accordance with evolving principles and norms.

NATO's status as a community of states sharing common values has been emphasized by analysts favoring normative perspectives. Proponents of this view note that NATO member governments are each guided by the principles of democracy, rule of law and respect for human rights. U.S. Deputy Secretary of State Strobe Talbott identified the allies' common desire to promote the expansion of desirable norms as one key to the Alliance's persistence, stating "During the Cold War, military and geopolitical

${ }^{117}$ Owen Harries, "The Collapse of the 'West'," Foreign Affairs 72, no. 4 (September/October 1993): 47. 
considerations mainly determined NATO's decisions. Promoting democracy within

NATO states and good relations among them was only complementary - desirable but not the primary motive for bringing in new members. But today, with the end of the Cold War, other, nonmilitary goals can and should help shape the new NATO."118 Gress even goes so far as to claim that during the Cold War "NATO's political and cultural role...was more important than its military role." 119

Koslowski and Kratochwil state that the events of 1989 "transformed the international system by changing the rules governing superpower conflict and, thereby, the norms underpinning the international system." 120 They depict the Cold War relationship between the United States and the Soviet Union as a social structure between two states identifying each other as enemies with conflicting national interests.

Gorbachev's policies of glasnost and perestroika effectively embraced norms more consistent with those of NATO members and led to a change in Soviet identity.

According to Wendt, when these states stopped identifying each other as enemies, the social structure changed and the Cold War ended. ${ }^{121}$ This change in identity affected the entire international system, aiding the emergence of an anarchy of friends.

${ }^{118}$ Strobe Talbott, "Why NATO Should Grow," New York Review of Books 42, no. 13 (August, 1995): 28.

${ }^{119}$ David Gress, From Plato to NATO: The Idea Of The West And Its Opponents (New York: The Free Press, 1998), 423.

${ }^{120}$ Rey Koslowski and Friedrich Kratochwil, "Understanding Change in International Politics: The Soviet Empire's Demise and the International System," International Organization 48, no. 2 (Spring 1994): 215.

${ }^{121}$ Alexander Wendt, "Anarchy is What States Make of It: The Social Construction of Power Politics," International Organization 46, no. 2 (1992): 391-425. 
McSweeney finds that while the Soviet Union and the Warsaw Pact dissolved under a new social structure, NATO continued to exist because its norms and rules are compatible with an anarchy of friends. ${ }^{122}$ In his view, NATO consisted of more than just a shared opposition to Soviet expansion; it reflects its members' shared commitment to liberal values, democratic governance, and economic interdependence. Both NATO and non-members were "seduced into a new set of practices and a new habit of identity" as they reconsidered their security and interests after the Cold War. ${ }^{123}$ As successor states to the Soviet Union and the Warsaw Pact chose to adopt identities compatible with those of NATO members, projects such as PfP became possible and the Alliance embraced several Central and Eastern European states as new members. The release of central and eastern European states from Soviet domination allowed for a new definition of Europe as a "geographical sphere of influence where Western norms and values shall prevail.", 24 The rise of the EU and the pursuit of CFSP in the decade following the Cold War threatened the creation of a European identity to rival the transatlantic identity embodied in NATO. The membership of the two regimes is similar, with the obvious exclusion of the United States from the EU. EU promotes exclusive identity distinct from transatlantic identity, since the United States is barred from participation. The particular nature of a European identity remains the subject of much scholarly speculation. According to Waever, " $[\mathrm{A}]$ mythic narrative of European history together with an international actor

\footnotetext{
${ }^{122}$ Bill McSweeney, Security, Identity and Interests: A Sociology of International Relations (Cambridge: Cambridge University, 1999).

${ }^{123}$ Ibid, 214.

${ }^{124}$ Robert Jackson, The Global Covenant: Human Conduct in World Affairs (New York: Oxford University Press, 2000), 189.
} 
profile can produce a European international identity." ${ }^{125}$ Smith recognizes European identity to be a "shared European experience" that is made up of a "cultural crossfertilization" rather than being tied to a single ethnic base. ${ }^{126}$ These traditions include Roman law, parliamentary institutions, Judeo-Christian ethics, humanism, romanticism and classicism. Smith argues that any European identity is weak in comparison to national histories, supported by vibrant myths, heroes, and legends. This view is shared by Leonard, who refers to Europe as a "patchwork of different cultures, religions, languages and views."127

The existence of established cultures has made it more difficult to establish a cosmopolitan European identity. As a result, European Union officials have undertaken a number of measures to promote the concept of a European identity. Gilles Andreani, then-head of the French Foreign Ministry noted, "The process of European integration is a joint exercise in norm-setting and institution-building. Institutions are supposed to provide for fairness and predictability, and inspire EU countries with a sense of purpose and belonging." 128 EU leaders have long sought ways to promote this sense of belonging, with the recognition that "imagined communities must be constantly reified to become

\footnotetext{
${ }^{125}$ Ole Waever, "The EU as a Security Actor: Reflections From a Pessimistic Constructivist on PostSovereignty Security Orders," in International Relations Theory and the Politics of European Integration: Power Security and Community ed. Michael Williams (London: Routledge, 2000), 279.

${ }^{126}$ Anthony Smith, "National Identity and the Idea of European Unity," International Affairs 68, no. 1 (1992): 70-71.

${ }^{127}$ Mark Leonard, Making Europe Popular: The Search for a European Identity (London: Demos, 1998).

${ }^{128}$ Gilles Andreani, “Why Institutions Matter," Survival 42 no. 2 (Summer 2000): 83.
} 
meaningful objects of identification."129 The EU's efforts to promote a European identity were very similar to those associated with the promotion of national identity. The EU's efforts to actively promote the concept of a distinct European identity increased with the release of the Adonnino Report in 1985. The report marked the beginning of a "People's Europe" campaign and the adoption of recognizable community symbols. The EU adopted Beethoven's Ode to Joy at its anthem and created the familiar twelve-starred flag that now flies not just over official EU facilities, but over national and private facilities that wish to promote European unity. The EU also recognized the importance of education to the promotion of a European identity. Article 126 of the Maastricht Treaty sought to develop a European dimension in education. While member states remained responsible for academic systems and curriculum, the EU sponsored several programs to encourage cooperative educational programs. These programs also subsidized the study of common history, which at least one study has credited with contributing to vast improvements in Franco-German relations. ${ }^{130}$

The process of European integration challenged the effectiveness of NATO by competing for resources and presenting and alternative, competing identity. The existence of multiple political identities, each having implications for security policy, made transatlantic relations increasingly complex. The persistence of multiple, and at times conflicting, political identities forced political leaders to interact through competing institutions. While these identities have much in common, such as the commitment to

\footnotetext{
${ }^{129}$ Thomas Risse, "The Euro Between National and European Identity," Journal of European Public Policy 10, no. 4 (August, 2003): 490.

${ }^{130}$ Smith, "National Identity and the Idea of European Unity," 65.
} 
democratic values, capitalism, and the rule of law, there are also emerging differences. These differences would have significant implications for transatlantic relations as the EU expanded its influence in the field of security.

Despite the emergence of another form of collective identity among Europeans, shared values and interests among the United States and its European allies did not disappear after the end of the Cold War. These states all sought to limit conflict among European powers, preserve free trade, ensure access to strategic resources, and limit the spread of local conflicts. NATO continued to contribute to the creation of a transatlantic security community, marked by the existence of shared ideology and adherence to common norms of state behavior. Expansion, EAPC and PfP all promoted the expansion of shared values into new parts of Europe, along with a sense that the security of all member states was linked. The shared interest in promoting common values and a recognition of the vital importance of maintaining peaceful relations among European states contributed to interventions in both Bosnia-Herzegovina and Kosovo. The 1999 Strategic Concept reiterated the Alliance's commitment to "common values of democracy, human rights, and rule of law, the Alliance has striven since its inception to secure a just and lasting peaceful order in Europe" and served as the foundation for a decision to expand the Alliance's activities outside of the region. ${ }^{131}$

\section{Conclusion}

In its first fifty years, NATO member states moved from an alliance focused entirely on territorial defense to a multifaceted set of principles, norms, rules and

\footnotetext{
${ }^{131}$ North Atlantic Treaty Organization, "The Alliance's Strategic Concept."
} 
procedures increasingly compatible with the practice of collective security. The process of regime change accelerated after the end of the Cold War as the Alliance found ways to pursue shared interests in a more permissive security environment. Power-based, organization-based, and norm-based approaches to regime analysis all contribute to an understanding of the process of regime change during the decade following the end of the Cold War. The United States, in its role as alliance hegemon, strove to preserve its influential role in European security and encouraged the Alliance's embrace of collective security. American leaders introduced many of the initiatives associated with this regime change and accepted a disproportionate amount of the burden for bringing them into practice. NATO's existing rules and procedures provided a strong foundation for the expansion of the Alliance's mandate to include collective security functions. Traditional NATO bodies encouraging an open dialogue among alliance members on security issues and the coordination of defense planning were made available to non-member states. From a norm-based perspective, a sense of community was preserved among Alliance members during this period based on the shared commitment to expand the common values of democracy, human rights, and rule of law. The allies continued to actively practice consultation and compromise to develop a consensus regarding how these values should be promoted, to include greater cooperation with former adversaries and the necessity of military interventions in the Balkans.

As NATO prepared to enter the $21^{\text {st }}$ century, the Alliance's commitment to the practice of collective security would face new challenges. NATO leaders had addressed some aspects of the "out-of-area" debate through its interventions in Bosnia-Herzegovina and Kosovo, including an increased willingness to view a consensus among member 
states as sufficient legitimacy for collective military action. According to one set of scholars, ““'Because Operation Allied Force proceeded without a wider international mandate, it could be argued that the Alliance's direct responsibility for a political settlement is deepened and that NATO's collective security obligations are now as extensive as its collective defense commitments."132 However, while Alliance members had been willing to pool their efforts to shape the strategic environment within Europe, future threats would surely bring their own unique complexities that could expose differences among Alliance members and limit the ability of the Alliance to take collective action. As the $21^{\text {st }}$ century was approaching, De Wijk observed, “a difference of opinion between the European members of the Alliance and the United States as to whether NATO is a regional or a global alliance."133 Similarly, Krause notes that "NATO is still a long way from defining itself as a coalition of those willing to export stability to regional theaters outside of Europe." ${ }^{134}$ The next chapter will examine the debate over further expanding the Alliance's mandate to reach outside of Europe and address the threats of international terrorism and WMD proliferation.

\footnotetext{
${ }^{132}$ Cathal Nolan and Carl Hodge, "'The Healthy Bones of a Single Pomeranian Grenadier': The Atlantic Alliance and the Humanitarian Principle," in NATO for a New Century: Atlanticism and European Security, ed. Carl Hodge (Westport, CT: Praeger, 2002), 15.

${ }^{133}$ Ron De Wijk, NATO on the Brink of the New Millennium: the Battle for Consensus (London: Brassey Press, 1997) 151.

${ }^{134}$ Joachim Krause, "Proliferation Risks and their Strategic Relevance: What Role for NATO?" Survival 37, no. 2 (Summer 1995): 147.
} 
At the start of the 21 st century we live in a new, closely interrelated world, in which unprecedented new threats and challenges demand increasingly united responses.

- Rome Summit Declaration by Heads of State of NATO Member States and the Russian Federation (2002)

Chapter 4: NATO's Role in the Global War on Terrorism

This chapter continues the examination of post-Cold War regime change within NATO by analyzing the Alliance's collective response to the threats of transnational terrorism and the proliferation of weapons of mass destruction following the September 2001 attacks on the United States. NATO's participation in both defensive and offensive operations associated with the American-led Global War on Terrorism (GWOT) required a consensus regarding the applicability of the regimes of collective defense and collective security to new threats emerging from well outside of the Alliance's traditional area of operations. This chapter begins with a review of the perception of the threats posed by transnational terrorism and Weapons of Mass Destruction (WMD) proliferation in the aftermath of the September 2001 attacks on the United States. The initial responses of NATO member states are examined, including their decision to invoke the collective defense clause of the North Atlantic Treaty for the first time in the history of the Alliance. This study continues with an account of the factors influencing the organization of international coalitions under the leadership of the United States for offensive military operations in Afghanistan and Iraq. This chapter concludes with an assessment of the contributions made by each of the three approaches to regime analysis to an understanding of the inconsistent commitment to collective action demonstrated by the allies throughout this period. While a collective defense regime was preserved throughout this period, the extension of NATO's collective security regime outside of 
Europe faltered due to an unwillingness of United States to share command responsibility, the inability of the Alliance to summon relevant capabilities, and a breakdown in the sense of community favoring a common perception of threats and a consensus regarding the appropriate courses of action to be taken.

\section{Nature of the Threat}

The tactic of terrorism has been practiced throughout human history. Sandler and Hartley define terrorism as "the premeditated use of, or the threat to use, extra-normal violence or brutality to gain a political objective through intimidation or fear."'

Terrorists aim to influence the policies of governments by creating a sense of insecurity among the general population of a state. This sense of insecurity can lead a population to question the ability of their government to provide for their safety and to demand policy changes to reduce their perception of danger. Terrorism is often practiced by non-state actors because it allows them to leverage their limited financial and military resources. Terrorism is traditionally viewed as a weapon used by the weak against the strong. It is a form of asymmetric warfare that allows small groups to pursue their political goals even when opposed by governments fielding large, modern militaries.

Over the past several decades, NATO member states have frequently been the target of groups employing terrorist tactics. The German and Italian governments faced attacks by extreme leftist movements such as the Red Army Faction and the Red Brigades. Both Spain and Great Britain struggled against internal separatist causes that led to the formation of terrorist groups associated with the Basque National Liberation

\footnotetext{
1 Todd Sandler and Keith Hartley, The Political Economy of NATO (New York: Cambridge University Press, 1999), 170-171.
} 
Movement and the Irish Republican Army. France faced Islamic extremists such as the Armed Islamic Group and the Salafist Preaching and Combat Group, both of which conducted hijackings and bombings into the 1990s. Terrorist attacks also occurred within the United States, including the 1993 bombing of the World Trade Center and the 1995 bombing of the Alfred P. Murrah Federal Building in Oklahoma City. In general, terrorist strikes were viewed as isolated criminal acts which did not rise to the level of a direct threat to national security. Previous debates over giving the NATO alliance greater authority to respond to acts of terrorism were rejected, primarily because terrorism was generally viewed as a domestic threat involving a single member government. $^{2}$

Both scholars and practitioners of international relations expressed growing concern for the threat posed by international terrorism toward the end of the twentieth century. A number of terrorist groups demonstrated both the willingness and ability to coordinate their efforts and to plan attacks resulting in unprecedented levels of violence. Changes in technology and the organization of the post-Cold War international system threatened to make future terrorist attacks more deadly. One scholar observed, "As the average state decreases in size [a trend demonstrated by the formation of numerous successor states following the breakup of the Soviet Union and Yugoslavia], while sophisticated weaponry becomes less and less expensive, the relative influence of nonstate actors is likely to rise. Thus technology may increasingly favor terrorists over

\footnotetext{
${ }^{2}$ Paul Gallis, NATO Enlargement: Congressional Research Service Report 21055, (Washington D.C.: Congressional Research Service, 2003), 4.
} 
states." A perceived increase in the threat posed by transnational terrorist groups to the community of NATO member states would eventually lead NATO leaders to revisit the question of developing organizational capabilities to promote a collective response to terrorism. As U. S. Senator Richard Lugar observed in late 2001, "In a world in which terrorist 'Article 5' attacks on our countries can be planned in Germany, financed in Asia, and carried out in the United States, old distinctions between 'in' and 'out-of-area' become meaningless... If 'Article 5' threats to our security can come from beyond Europe, NATO must be able to act beyond Europe to meet them if it is going to fulfill its classic mission today."

International terrorists began employing new and more threatening tactics in the 1990s, including the acquisition and use of WMD. The March 1995 nerve gas attack on a Tokyo subway by the Japanese religious sect Aum Shinri Kyo demonstrated the ability of some terrorist groups to acquire and employ chemical weapons. The leader of Al Qaeda, Osama Bin Laden, claimed to view the acquisition of WMD as his religious duty. Bin Laden stated, "Acquiring weapons for the defense of Muslims is a religious duty. If I have indeed acquired these weapons, then I thank God for enabling me to do so. And if I seek to acquire these weapons, I am carrying out a duty. It would be a sin for Muslims not to try to possess the weapons that would prevent the infidels from inflicting harm on

\footnotetext{
${ }^{3}$ Stuart Kaufman, "The Fragmentation and Consolidation of the International System," International Organization 51, no. 2 (Spring 1997): 200.

${ }^{4}$ Daniel Hamilton and Tim Garden, "Should NATO's New Function be Counter-Terrorism?" NATO Review 50, no. 2 (Summer 2002): 17.
} 
Muslims." The willingness of these groups to employ such weapons signaled a change from the more modest tactics and objectives historically associated with terrorism. A 2000 study by the National Commission on Terrorism concluded that contemporary terrorist groups were more often motivated by fanaticism than political interests and that these groups were less restrained in their methods. ${ }^{6}$

Al Qaeda's rise in the 1990s exemplified the growing threat of international terrorism to Western interests. Osama Bin Laden began his campaign against the United States in response to the deployment of American forces to Saudi Arabia during the Persian Gulf War. He fought against the Soviets during the 1980s in Afghanistan and maintained contacts throughout this region as well as in Southeast Asia and in Northern Africa. Frank J. Cilluffo, who would later become the Special Assistant to President George W. Bush for Homeland Security, described Bin Laden's role in Al Qaeda as "the chief executive and chief financial officer of a loosely affiliated group of radical terrorists, who share resources, assets and expertise, and who can come together for an operation and then disperse. Al Qaeda is simply the most visible head of a hydra.,"7 Bin Laden's network would eventually spread across the globe, establishing cells in at least 60 states and conducting attacks on several continents.

Bin Laden's hostility toward the West came into focus with his declaration of a fatwah against the United States and its allies in February 1998. Bin Ladens's

\footnotetext{
5 "Exclusive Interview: Conversation with Terror," Time, January 11, 1999. http://www.time.com /time/asia/news/interview/0,9754,174550-2,00.html

${ }^{6}$ National Commission on Terrorism, Countering the Changing Threat of International Terrorism: Report of the National Commission on Terrorism (Washington: GPO, 2000).
}

${ }^{7}$ Frank Cilluffo and Daniel Rankin, "Fighting terrorism," NATO Review' 49 no. 4 (Winter 2001): 13 
"Declaration of the World Islamic Front for Jihad against the Jews and the Crusaders" outlined his allegations against the West and stated "We, with God's help, call on every Muslim who believes in God and wishes to be rewarded to comply with God's order to kill Americans and their allies, both civil and military, is the individual duty of every Muslim who is able...until their armies, shattered and broken-winged, depart from all the lands of Islam."8 Later that year, Al Qaeda carried out nearly simultaneous bombings of American embassies in the African capital cities of Dar es Salaam, Tanzania and Nairobi, Kenya. The United States issued an indictment against Bin Laden and gained sufficient international support for the passage of a UN Security Council Resolution (UNSCR) demanding that the government of Afghanistan "stop providing sanctuary and training for international terrorists and their organizations, and that all Afghan factions cooperate with efforts to bring indicted terrorists to justice." These demands went unanswered, and the United States and it allies continued to search for ways to bring greater international pressure on terrorist groups and states seeking to acquire weapons of mass destruction.

The international community's efforts during the 1990s to verify the destruction of Iraq's WMD programs represented one front in this global counter-proliferation campaign. UNSCR 687, adopted by the Security Council shortly after the 1991 Persian Gulf War required Iraq to "unconditionally accept the destruction, removal, rendering harmless under international supervisions, of all chemical and biological weapons and all

\footnotetext{
${ }^{8}$ Bernard Lewis, "License to Kill: Usama bin Laden's Declaration of Jihad," Foreign Affairs 77, no. 6 (November/December 1998): 15.

${ }^{9}$ United Nations Documentation Center, "United Nations Security Council Resolution 1214, December 8, 1998," http://www.un.org/News/Press/docs/1999/.
} 
stocks of agents and all related subsystems and components and all research, development, support and manufacturing facilities related thereto" and to discontinue its support for terrorist groups. ${ }^{10}$ A United Nations Special Commission (UNSCOM) was established to verify Iraq's compliance with the disarmament provisions of UNSCR 687. UNSCOM's mission was to determine the extent of Iraq's WMD programs and supervise their destruction. While Iraq was originally given 15 days to declare all of its WMD and a year to destroy them, UNSCOM and the International Atomic Energy Agency (IAEA) conducted inspections over several years. Although UNSCOM succeeded in locating and destroying large numbers of Iraqi weapons, its inspections were frequently obstructed by Iraqi officials that resisted the inspector's efforts to visit some sites, conduct interviews with Iraqi scientists, or gain access to sensitive documents.

Seven years of sporadic inspections ended with the departure of UNSCOM in December 1998. UNSCOM's final report made it clear that Iraq had failed to fully cooperate with the inspectors, stating "Iraq's conduct ensured that no progress was able to be made in the fields of disarmament. In light of this experience, and in the absence of full cooperation by Iraq, it must, regrettably, be recorded again that the Commission is not able to conduct the work mandated to it by the Security Council with respect to Iraq's prohibited weapons program." 11 The following day, the United States and Great Britain began a four-day bombing campaign against suspected weapons sites throughout

\footnotetext{
${ }^{10}$ United Nations Documentation Center, "United Nations Security Council Resolution 687, April 3, 1991," http://www.un.org/News/Press/docs/1991/.

${ }^{11}$ United Nations Documentation Center, "Letter dated 15 December 1998 from the Executive Chairman of the Special Commission established by the Secretary-General pursuant to paragraph 9 (b) (i) of Security Council resolution 687 (1991)" http://www.un.org/Depts/unscom/s98-1172.htm
} 
southern and central Iraq. Operation Desert Fox took place without Security Council authorization due to divisions among the council's permanent members. President Clinton justified the strikes by emphasizing the need to demonstrate the continued will of the international community to enforce the inspections agreements. In his December $15^{\text {th }}$ address to the nation, Clinton stated, "If Saddam can cripple the weapons inspections system and get away with it, he would conclude that the international community, led by the United States, has simply lost its will. He will surmise that he has free rein to rebuild his arsenal of destruction. And some day, make no mistake, he will use it again, as he has in the past." ${ }^{\prime 2}$ American and British forces flew hundreds of aircraft sorties and launched cruise missiles at military facilities and locations suspected of concealing WMD programs. This attack marked a transition from a strategy of containment to one of removing Saddam Hussein from power.

American leaders justified their call for Saddam's removal on accusations that the Iraqi government maintained extensive ties to terrorist organizations, emphasizing the risk posed by a rearmed Iraq acting in collusion with international terrorist groups. Iraq's ties to Palestinian terrorist groups extended back to the 1970s. Iraq provided funding for the Palestine Liberation Organization (PLO) until 1974 and then shifted its financial support to the more radical Abu Nidal Organization (ANO). In October 1985, the Iraqi government allowed Yasser Arafat to temporarily relocate his headquarters to Baghdad following Israeli attacks on PLO facilities in Tunis. Iraq also provided sanctuary for the

\footnotetext{
${ }^{12}$ University of California American Presidency Project, "Address to the Nation Announcing Military Strikes Against Iraq, December 16, 1998," http://ww.presidency.ucsb.edu/ws/print.php?pid=55414.
} 
members of the Palestine Liberation Front (PLF) accused of hijacking the Italian cruise ship Achille Lauro. While the ANO and the PLF maintained a presence in Baghdad through the 1990s, there was no evidence that the Iraqi government encouraged these groups to attack targets in the United States and Europe. Iraqi leaders seemed to understand that evidence of their involvement in such an attack would very likely lead to renewed military action by an international coalition led by the United States.

Accusations of Iraqi ties to Al Qaeda surfaced throughout the 1990s, but were never well-substantiated. The secular Iraqi government had little in common with the Islamist Al Qaeda leaders beyond a shared dislike of the United States. Nonetheless, intelligence reports occasionally surfaced providing information on meetings between Iraqi agents and Al Qaeda representatives. ${ }^{13}$ A 1998 indictment by the Clinton administration against $\mathrm{Al}$ Qaeda leaders, asserted that they had "reached an understanding with the government of Iraq that Al Qaeda would not work against that government and that on particular projects, specifically including weapons development, Al Qaeda would work cooperatively with the government of Iraq." ${ }^{14}$ Secretary of State Colin Powell would later summarize American concerns in remarks to the United Nations, stating "Terrorism has been a tool used by Saddam for decades. Saddam was a supporter of terrorism long before these terrorist networks had a name, and this support

\footnotetext{
${ }^{13}$ Stephen Hayes, “An Intelligent Democrat," The Weekly Standard, December 15, 2003.

${ }^{14}$ Rowen Scarborough, "Clinton First Linked Al Qaeda to Saddam," Washington Times, June 28, 2004.
} 
continues. The nexus of poisons and terror is new. The nexus of Iraq and terror is old. The combination is lethal.",15

By the end of the 1990s, American leaders had begun to view the nexus between international terrorism and WMD proliferation as worthy of greater attention within NATO. Many NATO leaders were less receptive to proposals to include a more explicit counter-terrorism role for the Alliance in the revised Strategic Concept. Opposition was encountered by officials from France, Spain, Germany, and Turkey, who continued to view terrorism primarily as a domestic law enforcement issue. ${ }^{16}$ The new Strategic Concept included terrorism among the list of "other risks" to the Alliance, but failed to provide specific guidance to subordinate NATO bodies. At the 1999 Washington Summit, American officials succeeded in getting the North Atlantic Council (NAC) to agree to establish a WMD Center in an effort to implement the goal of intelligence sharing and to "ensure a more vigorous, structured debate at NATO leading to strengthened common understanding among allies on WMD issues and how to respond to them." 17 While these initiatives increased the awareness of these threats among Alliance members, they fell short of a clear shift in Alliance priorities. The election of George W. Bush in November 2000 provided an opportunity for American leaders to reconsider their approach to countering the threats of international terrorism and WMD proliferation as part of a revised approach to U.S. foreign policy.

\footnotetext{
${ }^{15}$ U.S. Department of State, "Secretary Powell Remarks to United Nations Security Council, February 5, 2003," http://www.state.gov/secretary/former/powell/remarks/2003/17300.htm

${ }^{16}$ Matthew Kaminski, "NATO is Unprepared to Fight Terrorism," Wall Street Journal, October 8, 2001.

${ }^{17}$ NATO Office of Information and Press, "Washington Summit Communique: An Alliance for the $21^{\text {st }}$ Century, April 24, 1999," http://www.nato.int/docu/pr/1999/p99-064e.htm.
} 
The September 2001 attacks by Al Qaeda on the United States occurred while the Bush administration was in the midst of reshaping American foreign policy. During the 2000 presidential campaign, then-Governor Bush had been critical of the Clinton Administration's foreign policy, which Clinton's Secretary of State Madeleine Albright characterized as "aggressive multilateralism." Bush expressed concern over President Clinton's willingness to commit military forces to various peacekeeping and nationbuilding operations without sufficiently justifying how these operations were consistent with the vital interests of the United States. In a February 2000 article in Foreign Affairs, his foreign policy advisor, Condoleeza Rice, called for foreign policy changes more clearly linked to the pursuit of American national interests. Rice stated, "The belief that the United States is exercising power legitimately only when it is doing so on behalf of someone or something else was deeply rooted in Wilsonian thought, and there are strong echoes of it in the Clinton administration. To be sure, there is nothing wrong with doing something that benefits all humanity, but that is, in a sense, a second-order effect." ${ }^{18} \mathrm{~A}$ change of leadership was expected to bring about a foreign policy that enabled the United States to unabashedly pursue its interests. Shortly after the election, Charles Krauthammer observed, “An unprecedentedly dominant United States...is in the unique position of being able to fashion its own foreign policy. After a decade of Prometheus

\footnotetext{
${ }^{18}$ Condoleeza Rice, "Campaign 2000: Promoting the National Interest," Foreign Affairs 79, no. 1, (January/February 2000): 47.
} 
playing pygmy, the first task of the administration is precisely to reassert American freedom of action." 19

During his first few months in office, President George W. Bush made a number of decisions that contributed to perceptions that the United States was becoming more unilateralist. He announced his intention to withdraw from the 1972 Anti-Ballistic Missile (ABM) treaty in order to pursue plans to develop a Ballistic Missile Defense (BMD) system. The United States' abandonment of this treaty concerned its NATO allies, who felt this decision could undermine the continued efficacy of international arms control and nonproliferation efforts. The Bush administration also reversed the previous administration's support for the 1997 United Nations Kyoto Treaty on Climate Change, ending efforts to pursue Senate ratification. In addition, American officials took measures to retard the organization of an International Criminal Court (ICC) through the United Nations. President Bush withdrew President Clinton's signature from the treaty and pursued an exemption for Americans participating in UN-sponsored peacekeeping missions. The administration made American foreign aid conditional to the creation of bilateral agreements preventing other states from prosecuting Americans through the ICC. These indications that the United States was becoming less willing to compromise its national interests for the sake of international cooperation dominated early impressions of the Bush administration's foreign policy preferences.

The 2001 attacks by Al Qaeda on the United States occurred nine months into President George W. Bush's first term in office. The thousands of casualties experienced

\footnotetext{
${ }^{19}$ Charles Krauthammer, "The New Unilateralism," The Washington Post, June 8, 2001.
} 
in these attacks represented the most deadly series of terrorist attacks in history and presented the United States and its allies with a demanding and unprecedented foreign policy challenge. Allied expressions of support for the United States were immediate and resolute. British Prime Minister Tony Blair declared that the United Kingdom would stand "shoulder to shoulder" with the United States as it recovered from the attacks while German Chancellor Gerhard Schroeder condemned the attacks as a "declaration of war on the free world." ${ }^{20}$ NATO's Secretary General, George Robertson, also released a statement declaring "I condemn in the strongest possible terns the senseless attacks which have just been perpetrated against the United States of America... These barbaric acts constitute intolerable aggression against democracy and underlie the need for the international community and the members of the Alliance to unite their forces in fighting the scourge of terrorism."21 The non-member states participating in Euro-Atlantic Partnership Council (EAPC) also expressed their support, stating, "We are appalled by these barbaric acts and condemn them unconditionally. These acts were an attack on our common values. We will not allow these values to be compromised by those who follow the path of violence. We pledge to undertake all efforts to combat the scourge of terrorism. We stand united in our belief that the ideals of partnership and co-operation will prevail. ${ }^{22}$ NATO was poised to play an important role in any response to these

\footnotetext{
20 "Old Friends, Best Friends," The Economist, September 13, 2001. http://www.economist.com/ printedition/displayStory.cfm?Story_ID=780405

${ }^{21}$ NATO Office of Information and Press, "Statement by the Secretary General of NATO, September 11 , 2001," http://www.nato.int/docu/pr/2001/p01-121e.htm.

${ }^{22}$ NATO Office of Information and Press, "Statement by the EAPC, September 12, 2001," http://www.nato.int/docu/pr/2001/p01-123e.htm.
} 
attacks, as these events "were widely interpreted in Europe as a broader attack on Western values of freedom, tolerance, and openness."23

The United States turned to its NATO allies for support well before determining the precise nature of its desired response. Lord Robertson suggested invoking the collective defense clause of the North Atlantic treaty, telling U.S. Secretary of State Colin Powell, "Invoking Article Five would be a useful statement of political backing, that it would help the United States build an instant anti-terror coalition based in part on the moral authority behind Article Five, and that it would be a deterrent - in that whoever was responsible for the attack would know they had taken on not just the United States, but also the greatest military alliance in the world." 24

The invocation of Article Five characterized a response to these attacks as an act of collective self-defense, authorizing, but not requiring, a military response in accordance with a collective defense regime. NATO had never invoked Article Five in the history of the Alliance and the conditions surrounding this request were certainly different than those envisioned by the authors of the treaty. In an unusual turn of events, this request would primarily involve the European members of NATO coming to the assistance of the United States. In addition, the allies would be responding to an act of violence carried out by a non-state actor, rather than a conventional act of interstate aggression. Given the uncertainty identifying precisely who had carried out the attacks and the type of response contemplated by the United States, some members of the NAC

\footnotetext{
${ }^{23}$ Nora Bensahel, The Counterterror Coalitions: Cooperation with Europe, NATO, and the European Union (Santa Monica, CA: RAND, 2003), 1.

${ }^{24}$ James Kitfield, “NATO Metamorphosis,” National Journal 34, no. 6 (February 2002): 376-380.
} 
expressed caution. In an effort to demonstrate solidarity with the United States, while respecting the concerns of several European allies, the NAC agreed to provisionally invoke Article Five. Further action would be deferred until more was known about those responsible for the attacks and a consensus could be reached regarding the nature of the collective response.

The subject of invoking Article Five prompted some debate among member states, and a genuine concern by some NATO officials that the Alliance would be unable to organize a collective response. Article Five had primarily been viewed as a means of deterring or responding to an attack by a state outside of the Alliance rather than a nonstate actor. The British were among the earliest supporters of the invocation of Article Five and were the first nation to pledge troops to any subsequent military action. German diplomats were much less comfortable with the concept of applying NATO's collective defense regime to acts of terrorism. While Chancellor Gerhard Schroeder appeared to favor a collective response, any deployment of German troops would have to be approved by a Bundestag dominated by a Social Democrat/Green party majority, potentially resulting in a long, public debate over the appropriate level of German support.

Support for NATO's involvement was also mixed among members of the French government. Control of the French government was divided at the time among the conservative Gaullist party and the Socialist party. While Gaullist President Jacques Chirac was generally supportive regarding American requests for assistance, the Socialists, including Prime Minister Lionel Jospin, were less enthusiastic. The collective response demanded by an Article Five declaration would likely involve the coordination of many government agencies previously outside the reach of NATO bodies, and few 
French leaders were anxious to give NATO that much authority. Additional concerns were raised within France about the ability of a military alliance to address such an unconventional threat.

The invocation of Article Five in this instance introduced a great deal of uncertainty for European members regarding the costs and benefits of collective action. A well-orchestrated counter-terrorism campaign could reduce the long term threat posed by both domestic and international terrorist organizations. However, participation in such a campaign would involve unknowable financial and military commitments and would likely increase the risk of attacks in the short term. These leaders also recognized the additional complexities of military action if the attacks were found to have been carried out by groups operating within the territory of a NATO member state. As a military alliance, NATO had no authority over domestic law enforcement agencies and would encounter numerous difficulties coordinating operations within their own borders. Invoking Article Five in response to terrorist attacks on the United States would also set an important precedent that other states could follow in the event of future terrorist attacks. Many NATO member states struggled with domestic sources of terrorism and the use of Article Five to combat terrorism could force the Alliance to consider operations against domestic sources of terrorism in the future.

American leaders were quickly convinced by the available intelligence that $\mathrm{Al}$ Qaeda, rather than a domestic terrorist group, had been responsible for the attacks. A U.S. State Department team briefed the NAC on October 2, 2001, producing evidence of that the attackers were funded and trained by Al Qaeda members operating out of Afghanistan. These diplomats emphasized the importance of NATO's expression of 
political solidarity with the United States, but did not pursue the option of organizing a military intervention under NATO command. Deputy Secretary of State Richard Armitage reported later that he told the NAC, "I did point out that in this coalition building there is a continuum from, on the one hand, rhetorical or political support for activities on this global attack on terrorism. It runs the gamut to sharing of intelligence, sharing of financial information, perhaps overflight rights, etc. And at the far end of the continuum is the possibility of some military activity either together or unilaterally., 25

In a press statement released just after the meeting of the NAC, Lord Robertson concluded, "We know that the individuals who carried out these attacks were part of the worldwide terrorist network of Al Qaeda, headed by Osama bin Laden and his key lieutenants and protected by the Taliban. On the basis of this briefing, it has now been determined that the attack against the United States on 11 September was directed from abroad and shall therefore be regarded as an action covered by Article 5 of the Washington Treaty, which states that an armed attack on one or more of the allies in Europe or North America shall be considered an attack against them all."26 The decision to invoke Article Five meant that NATO would aid the United States in carrying out a response to these attacks, even to the extent that this response involved military operations well beyond its members' borders. As General Klaus Naumann, the Chairman

\footnotetext{
${ }^{25}$ NATO Office of Information and Press, "Press Availability: U.S. Deputy Secretary of State Armitage and NATO Secretary General Lord Robertson, September 20, 2001," http://www.nato.int/docu/speech/ 2001/s010920a.htm.
}

${ }^{26}$ NATO Office of Information and Press, "Statement by Lord Robertson, October 2, 200I" http://www.nato.int/docu/speech/2001/s011002a.htm. 
of NATO's Military Committee later clarified, "The pledge to support the United States came with no geographical limits: de facto, NATO became a global alliance.,27

The confirmation of NATO's invocation of Article Five paved the way for more substantial acts of assistance on the part of NATO member states. One of the first ways that NATO states were able to assist the Americans in preparing for a strike against $\mathrm{Al}$ Qaeda and the Taliban was to enable the United States to lower its troop commitments in Europe. The United States hoped to build up its forces in Central Asia without having to mobilize large numbers of National Guard and Reserve troops. One means of accomplishing this was to transfer forces from NATO operations in Europe to Afghanistan. Several NATO allies offered some relief to American forces by increasing the size of their contingents participating in peacekeeping operations in the Balkans. Greece offered to provide additional troops to offset the reduction of American forces. Norway offered to assume Lead Nation status in the Kosovo Force (KFOR), adding an additional two hundred troops to the 1,000 Norwegians already serving in this operation. ${ }^{28}$ Germany also deployed additional troops to bolster peacekeeping efforts in Macedonia. These deployments would allow a counter-terrorism campaign to be planned and conducted while still maintaining the Alliance's security commitments in Europe.

NATO governments placed their security forces on a heightened state of alert and increased their domestic counter-terrorism efforts in response to American concerns. Upon discovering that an Al Qaeda cell operating in Hamburg, Germany had played a

\footnotetext{
${ }^{27}$ Klaus Naumann, "Crunch Time for the Alliance," NATO Review 50, no. 2 (Summer 2002): 9.

${ }^{28}$ Norwegian Ministry of Defense, "KFOR 5-Norway's Role as lead Nation" http://odin.dep.no/fd/ engelsk/publ/veiledninger/010011-120019/dok-nn.html.
} 
key role in planning the September $11^{\text {th }}$ attacks, CIA Director George Tenant reportedly told the National Security Council, "The best thing the Germans can do is get their act together on their own internal terrorist problems and the groups that we know are there." 29 In response to American pressure, the German government made the disruption of additional terrorist cells a top priority along with increased security for both German and American governmental buildings. Belgium, Great Britain, France, Italy and Turkey also implemented stronger security measures around the American and Israeli diplomatic missions, and other likely terrorist targets. France was the first European state to introduce the requirement for air marshals on international flights, placing a French air marshal on the very first flight between France and the United States when commercial air travel was restored on September 14, 2001. ${ }^{30}$ NATO member states worked to better coordinate their individual efforts to increase security, recognizing that vulnerabilities in one state could affect the security of all Alliance members.

NATO states played a large role in the global financial crackdown on international terrorist groups. Much of the funding for international terrorism was channeled through charitable organizations, in an attempt to circumvent recent UN restrictions on such funding, including the 1999 United Nations Convention on the Suppression of Terrorist Bombings and the 2000 United Nations Anti-Terrorism Financing Convention. U.S. Treasury Department officials worked with allied governments to implement more rigorous procedures for scrutinizing the accounts of

\footnotetext{
${ }^{29}$ Bob Woodward, Bush at War (New York: Simon and Shuster, 2002) 180.

${ }^{30}$ Embassy of France in the United States, "France's Response to 9/11," http://www.francetourism.com/ update_Vigipirate.asp
} 
individuals and organizations suspected of financing terrorism. This review resulted in the identification and seizure of twenty accounts in overseas banks with links to Al Qaeda by the end of September. ${ }^{31}$ The British government tasked nearly six hundred national banks and investment facilities with a comprehensive review, and by the end of November 2001 had frozen $£ 77$ million in 38 accounts. ${ }^{32}$ The French Ministry of Economic Affairs, Finance, and Industry similarly reviewed suspected accounts in France and by the end of December had frozen about 4.42 million Euro worth of funds belonging to individuals and groups with links to Al Qaeda and the Taliban. ${ }^{33}$

In December 2001, the NATO defense ministers tasked the Supreme Allied Commander Europe (SACEUR) and the Supreme Allied Commander Atlantic (SACLANT) to produce a military concept for defending against terrorism. The Military Concept for Combating Terrorism, which was officially approved during the November 2002 Prague Summit, organized Alliance contributions in defensive antiterrorism operations, consequence management, offensive counter-terrorism, and military cooperation with civil authorities. ${ }^{34}$ Specific recommendations included measures to improve air and maritime protection and the creation of standing NATO forces for consequence management. These forces would be available to be called on by member

\footnotetext{
${ }^{31}$ White House Office of Press Secretary, "Fact Sheet: Operation Enduring Freedom Overview: Campaign Against Terrorism Results, Period Covered 14-30 September 2001," October 1, 2001.

${ }^{32}$ Stephan De Spiegeleire, et al, Quick Scan of Post 9/11 National Counter-Terrorism Policymaking and Implementation in Selected European Countries: Research Project for the Netherlands Ministry of Justice (Santa Monica: RAND, 2002), 121-3.

${ }^{33}$ Ibid, 52.

${ }^{34}$ NATO Office of Information and Press, "NATO's Military Concept for Defense Against Terrorism, November 21, 2002," http://www.nato.int/ims/docu/terrorism.htm
} 
governments in the aftermath of a WMD attack. NATO also established the CivilMilitary Planning Directorate with responsibilities for consequence management. This directorate initiated an annual consequence management exercise, which served as a yearly assessment of the readiness of member states to mitigate the damage resulting from a terrorist attack. Finally, the military concept clarified that NATO may participate in offensive counter-terrorism actions either in a NATO-led force or as part of an operation led by another international organization or NATO member state.

NATO member states agreed to enhance intelligence sharing and cooperation, both bilaterally and through new organizational entities. Obstacles to sharing tactical intelligence on terrorist threats were examined and eliminated. The intelligence agencies of member states began communicating more frequently, combining their watch lists of both individuals and groups with links to terrorism. A review of intelligence practices within the Alliance exposed the need to establish procedures for shared analysis of events leading up to an international crisis. U.S. National Security Advisor Condoleezza Rice emphasized the value of this cooperation during a November 2001 press conference, stating "The key to the broad coalition is to remember that, while everybody understandably wants to focus on military contributions, this is not the Gulf War. An equally important part of this war on terrorism is the disruption of these terrorist cells abroad. If you imagine that there are cells out there in sixty-plus countries that could be continuing to plot, continuing to look for ways to wreak havoc, the intelligence and law enforcement efforts that have resulted in over three hundred arrests of known and suspected Al Qaeda operatives is as important to this war on terrorism and to trying to 
avoid another attack, either on ourselves or on others, as is the war in Afghanistan." ${ }^{35}$ NATO leaders strove for even greater results as they searched for ways to overcome differences in the acquisition and analysis of intelligence.

The NATO Intelligence Warning System (NIWS) emerged from a review of intelligence sharing procedures directed by the NAC. The creation of NIWS was intended to move away from the exchange of intelligence related to the status of conventional military threats, toward a process of intelligence analysis emphasizing emerging threats or regional crises. NIWS was given the mandate to "warn of any developing instability, crisis, threats, risks, or concerns that could impact on the security interests of the Alliance and monitor de-escalation of a crisis." ${ }^{36}$ NIWS personnel were tasked to perform qualitative analysis of data related to events of interest to member states, whether they occur within NATO territory or in neighboring states. By sharing some of these warnings, the allies would have a more even access to intelligence and a greater likelihood of developing the political will to take collective action.

NATO leaders agreed to increase cooperation and coordination through further support for NATO's WMD Center. This center was given additional resources to assist its efforts to promote a common understanding on WMD issues among member states. These efforts included the development of a public information strategy to increase the awareness of proliferation issues, the exchange of information on how to enhance military readiness to operate in a WMD environment how to protect civilian populations

\footnotetext{
${ }^{35}$ White House Office of Press Secretary, "Press Briefing by National Security Advisor Condoleezza Rice, November 8, 2001," http://www.whitehouse.gov/news/releases/2001/1 1/20011108-4.html.

${ }^{36}$ John Kriender, “Anticipating Crises,” NATO Review 50, no. 4 (Winter 2002): 15.
} 
in the event of a WMD attack. The center also worked to reduce the risk posed by weapons proliferation by briefing member and non-member states on the destruction of WMD stockpiles in Russia and elsewhere. In addition to advising other NATO committees, the WMD Center conducted briefings with the EAPC, along with several states participating in the Mediterranean Dialogue, and held discussions with the governments of both Russia and Ukraine. The center also took steps toward establishing a deployable Nuclear, Biological, and Chemical (NBC) analytical laboratory manned by an NBC event response team made up of experts from NATO member sates.

An increase in the quality and quantity of information exchanged among NATO member states was only one part of American efforts to improve international counterterrorism and counter-proliferation efforts. American diplomats capitalized on the extraordinarily strong levels of international empathy had arranged for dozens of declarations of support from international organizations. In addition to NATO's invocation of Article Five, the collective defense clause of the ANZUS treaty between the United States, Australian and New Zealand had been invoked along with a similar clause in the Pan-American Rio Treaty. In all, more than 100 states offered their cooperation and the Bush administration conducted counter-terrorism operations with 200 different intelligence or security services around the world. ${ }^{37}$ This support was in addition to the 30 states that offered the United States cooperation and support in criminal investigations.

\footnotetext{
${ }^{37}$ U.S. Department of State, "Operation Enduring Freedom Overview: Campaign Against Terrorism Results, Period Covered 14-30 September 2001," http://www.state.gov/s/ct/index.cfm?docid=5194.
} 
Generous offers of support flowed in from around the world, giving the United States access a great deal of flexibility in the way it would conduct the initial phases of the GWOT. By the end of September 2001, 27 states had given the United States permission to operate on their territory or transit through their airspace as part of a future military operation. ${ }^{38}$ A number of NATO member states had expressed a willingness to send military forces to conduct offensive military operations in Afghanistan alongside the United States. Canada, Great Britain, France, Italy, Norway, Spain and Turkey, all pledged to deploy ground, air, and naval forces, as needed. Some allies were initially unable to commit troops due to legislative constraints. Belgium, for example, was limited to deploying up to 1,000 troops outside of its borders, a limit already met through its participation in NATO operations in the Balkans. Germany also had to follow strict constitutional guidance before deploying troops outside of its borders. The organization of an American-led coalition to conduct offensive military operations in Afghanistan was driven by command structure considerations and the respective capabilities of allied military forces.

\section{Command Structure Considerations}

Following its military interventions in Kosovo, NATO was promoted as the only international organization capable of successfully organizing large-scale military interventions in the post-Cold War era. Both the EU and UN had failed to organize forces that could effectively intervene in the Balkans conflicts. NATO alone had eventually brought an end to the fighting in both Bosnia-Herzegovina and Kosovo and

\footnotetext{
${ }^{38}$ Ibid.
} 
remained crucial to subsequent efforts to maintain peace in the region. NATO appeared to be poised to serve as a foundation for future collective military operations, including out-of-area operations, as endorsed by the 1999 Security Concept.

A NATO-led Combined Joint Task Force (CJTF) was one option for the organization of a multinational coalition to conduct counter-terrorism operations in Afghanistan. The decision to use NATO's integrated command structure represented an opportunity to expand the Alliance's mandate outside of Europe. Several observers called for the creation of a NATO CJTF to oversee both the military and non-military aspects of the imminent counter-terrorism campaign. Sloan provided a representative argument in favor of such a CJTF, claiming that a NATO-led operation would lend greater legitimacy to military operations in Afghanistan. ${ }^{39}$ NATO's leadership of such a CJTF would give the European allies greater influence over the conduct of the campaign as well as a larger stake in the outcome. Structuring the campaign as a collective effort would induce greater participation among European allies along with more equitable burden-sharing. Sloan argued, "Given invocation of Article 5 and the explicit willingness of many NATO allies to contribute military capabilities to the war against terrorism, a political consensus existed that could have been used to expand NATO's horizons and establish a mechanism for NATO contributions in the future." ${ }^{40}$ The flexibility inherent in the CJTF concept allowed for the participation of both NATO member and nonmembers states. Sloan noted, "One advantage of the CJTF structure is that non-NATO

\footnotetext{
${ }^{39}$ Stanley Sloan, "Give NATO a Combined Task Force Against Terrorism," International Herald Tribune, November 13, 2001.

${ }^{40}$ Stanley Sloan, “Crisis Response," NATO Review 50, no.1 (Spring 2002): 28.
} 
allies can be invited to participate. All the countries that want to become NATO members as well as other European democracies would likely join in...NATO could, in effect serve as a clearing house for existing and future allied contributions to the war on terrorism." 41

A NATO CJTF would utilize command and control procedures tested in BosniaHerzegovina and Kosovo and further modified through ongoing efforts to restructure the Alliance commands. All military operations authorized by the NAC were headed by the Supreme Allied Commander Europe (SACEUR), an American officer also assigned as the commander of United States Forces in Europe (EUCOM).$^{42}$ Regional commanders subordinate to SACEUR commanded operations in their sector of responsibility. In December 1997, NATO revised its command structure from three regional commands (North, Central, and South) to two (North and South). The leadership of each regional command generally went to the member state providing the preponderance of forces, with the command of Allied Forces North (AFNORTH) expected to rotate between a British and a German officer while Allied Force South (AFSOUTH) was historically commanded by an American officer. While the NATO CJTF command structure was still evolving at the time of the Al Qaeda attacks, existing guidance called for a CJTF headquarters to be formed from elements of the selected regional headquarters and augmented from other NATO headquarters as necessary.

\footnotetext{
${ }^{41}$ Sloan, "Give NATO a Combined Task Force Against Terrorism."

${ }^{42}$ United States European Command (EUCOM) is one of five regional combatant commands with an area of responsibility encompassing Europe, most of Africa, and parts of the Middle East.
} 
A NATO-led military force for Afghanistan would most likely have followed a command structure similar to that of ongoing NATO operations in Kosovo. NATO command arrangements had been modified for both KFOR and SFOR in January 2001 to establish unity of command over NATO forces involved in each operation. The Commander-in-Chief, Allied Forces Southern Europe (CINCSOUTH) was given responsibility for the conduct of peacekeeping operations in both Bosnia-Herzegovina and Kosovo as part of his regional responsibilities. CINCSOUTH assumed the duties of Joint Force Commander, assisted by component commanders. Air forces fell under the direction of the Commander Allied Air Forces Southern Europe (COMAIRSOUTH). Maritime activities were directed by the Commander Allied Naval Forces Southern Europe (COMNAVSOUTH) and the remaining ground and supporting forces received their direction from the Commander Striking and Support Forces Southern Europe (COMSTRIKFORSOUTH). The role of the Supreme Headquarters Allied Powers Europe (SHAPE) was limited to providing strategic military guidance based on decisions from the NAC. ${ }^{43}$

The creation of a NATO CJTF as the focal point for the war in Afghanistan was rejected for a number of reasons. For one, NATO CJTF headquarters structures had not yet been declared operational. The procedures and facilities for the command and control of such a CJTF were in work and were not scheduled to be fully operational until 2004 . Secondly, the designation of a CJTF commander, would force NATO leaders to revisit command issues still unresolved from OAF. French criticism of the command structure

\footnotetext{
${ }^{43}$ NATO Office of Information and Press, "Allied Forces Southern Europe, Operation Joint Guardian Overview," http://www.afsouth.nato.int/operations/kfor/kfor $2 . \mathrm{htm}$.
} 
utilized in OAF included, "The commander of United States forces in Europe, and NATO's military commanding general, tends to be subsumed by U.S. plans and command in case of a crisis. In this argument, Operation Allied Force in Kosovo was the most recent example of NATO military and political authorities merely ratifying American military plans and operations." ${ }^{44}$ Lastly, while an American CJTF commander could draw upon complementary staffs serving in both SHAPE and EUCOM, the personnel on these staffs did not have sufficient regional expertise to oversee operations in Afghanistan.

NATO's existing command structure was optimized for operations within Europe, and had no particular experience or expertise to suggest a readiness to conduct offensive military operations in other regions. The close proximity of many NATO member states to the Balkans made NATO's access to their installations and manpower crucial to military operations in Bosnia-Herzegovina, Kosovo, and later in Macedonia. The proximity of these states to the conflict also gave these allies a heightened interest in the peaceful resolution of those conflicts and encouraged high levels of cooperation. Europeans could reasonably be expected to have access to valuable human intelligence or otherwise provide insights into the conflict due to their deep historical ties to the parties on both sides of the conflict. This regional expertise of these allies could not be expected to translate well to military operations outside of continental Europe.

American officials may have been willing to give greater consideration to a NATO-generated force if this type of coalition gave the United States access to much-

\footnotetext{
${ }^{44}$ Guillaume Parmentier, “Redressing NATO’s Imbalances," Survival 42, no. 2 (2002): 96-112.
} 
needed military capabilities. In reality, European member states did not have the military capabilities to make a decisive contribution to the type of military campaign anticipated by American leaders. Military operations in Afghanistan would involve conducting highintensity combat operations far from Europe and under conditions to which the military forces of the United States were better suited than those of its NATO allies. American leaders were also concerned by the public comments of several European leaders that indicated they would be cautious about the scope of military operations in Afghanistan. French Prime Minister Lionel Jospin was quoted as emphasizing the need for "proportional" strikes against terrorist targets in Afghanistan, while Belgian Prime Minister Guy Verhofstadt declared that any military strikes must "be focused on terrorist organizations... It is evident that we will never take part in a wider world conflict." ${ }^{, 45}$

Finally, a sense of urgency regarding the need to respond quickly and decisively to the September 2001 attacks was another factor that hindered the creation of a NATOled force. This sense of urgency was not nearly as strong in the months leading up to Operation Deliberate Force (ODF) or Operation Allied Force (OAF). NATO's intervention in Bosnia-Herzegovina was a gradual event, occurring years after the outbreak of hostilities and only after a careful and thorough diplomatic debate. NATO's reaction to events in Kosovo was more rapid, but offensive operations still only occurred after many months of planning and diplomatic negotiations. American leaders expressed a desire to retaliate quickly against $\mathrm{Al}$ Qaeda while both international and domestic support for a military response remained high. In his initial direction to his senior

\footnotetext{
${ }^{45}$ Ibid, 100.
} 
military commanders, U.S. Secretary of Defense Rumsfeld emphasized that they should "think days or weeks" until the beginning of military operations. ${ }^{46}$ Such an aggressive timeline was inconsistent with NATO procedures, where differences among allies must be resolved prior to any collective action in order to achieve a consensus. The several weeks between NATO's provisional invocation of Article Five on September 12, 2001 and the confirmation of the collective defense pledge following the meeting of the NAC on October 2, 2001 was just one indication that the organization of a multinational force for operations inside of Afghanistan would take quite some time.

An international coalition of forces operating through an American-led chain of command ultimately represented a simpler and more responsive solution from the perspective of American leaders. U.S. military doctrine called for American military forces to operate worldwide under a regional combatant command structure, and it was this structure that would serve as the foundation for the military coalition conducting Operation Enduring Freedom (OEF). Five regional combatant commands were in existence, with standing facilities and staffs preparing contingency plans for operations within their Area of Responsibility (AOR). Regional combatant commanders reported to the U.S. Secretary of Defense, who in turn reported to the President. Allied personnel could easily be incorporated into this command structure either as an adjunct force or directly under American command. As U.S. Deputy Secretary of State Richard Armitage described it, a U.S.-commanded coalition would provide an effective military force responsive to the desires of American leaders, allowing the United States to "pick and

\footnotetext{
${ }^{46}$ Woodward, Bush At War, 43.
} 
choose among its allies, fashioning moral authority of an international coalition without having to deal with the problems of the whole Alliance." ${ }^{, 47}$

Rather than requesting that the NAC authorize the organization of a NATO CJTF, President George W. Bush tasked the commander of United States Central Command (USCENTCOM), General Tommy Franks, with the development of a campaign plan for OEF. USCENTCOM was the regional combatant command responsible for the command of U.S. military forces operating in an AOR stretching from the Horn of Africa through the Middle East and into Central Asia. USCENTCOM commanders had led coalition forces during Operation Desert Storm in the 1990s and continued to oversee the conduct of Operation Southern Watch in Iraq. The USCENTCOM staff also had experience dealing with regional leaders as well as the expertise to overcome the inevitable problems of transporting and basing large numbers of American and allied forces in Central Asia. Military planning could take place rapidly by utilizing existing contingency plans estimating force availability and support requirements.

The differences in allied capabilities and operational concepts greatly influenced the role that NATO would play in both OEF and subsequent stabilization efforts. As American military planners built a strategy that came together favoring a combination of airstrikes and Special Operations Forces (SOF) operations rather than a large deployment of conventional forces, the participation of NATO allies became less crucial. Few NATO states had air and ground forces that complemented the strategy favored by American military commanders, which would limit their value to an American-led coalition. Upon

\footnotetext{
${ }^{47}$ NATO Office of Information and Press, "Press Availability: U.S. Deputy Secretary of State Armitage and NATO Secretary General Lord Robertson, September 20, 2001." http://www.nato.int/docu/speech/ 2001/s010920a.htm.
} 
learning of the American approach to an invasion of Afghanistan, a Dutch military analyst observed, "NATO forces are not training for this kind of work.,"48

NATO Secretary General George Robertson acknowledged the difficulty that the Alliance would encounter if it attempted to add a large scale warfighting operation to its existing list of responsibilities. In a January 2001 speech he noted, "For all the political energy expended in NATO to implement the Defense Capabilities Initiative, and in the EU to push ahead with the complementary Headline Goal process, the truth is that Europe remains a military pygmy. Orders of battle and headquarters wiring diagrams read impressively. Overall numbers of soldiers, tanks and aircraft give a similar impression of military power. But the reality is that we are hard pressed to maintain about 50,000 European troops in the region and that a new operation would oblige most European countries to slash their contingents in Bosnia, Kosovo and FYROM [former Yugoslav Republic of Macedonia] to produce usable forces in any numbers. ${ }^{, 49}$ The creation of another large intervention force under NATO command threatened the continuation of existing operations by placing an even greater demand on the dwindling personnel and resources of the European member states. While the attention of American leaders continued to shift toward more volatile regions outside of Europe, other NATO governments remained more inwardly focused. NATO leaders were preoccupied with ongoing operations in Europe, including peacekeeping efforts in the Balkans and conflict prevention efforts in Macedonia. EU member states were preparing for the EU's first

\footnotetext{
${ }^{48}$ Suzanne Daley, "NATO, Though Supportive, Has Little to Offer Militarily," The New York Times, September 20, 2001.

${ }^{49}$ NATO Office of Information and Press, "Speech by the Secretary General at the Annual Conference of the Defence and Society, January 21, 2002," http://www.nato.int/docu/speech/2002/s02012 la.htm
} 
round of enlargement and the organization of the ERRF. Each of these activities would affect the level of support that European militaries could provide to the GWOT.

The Bush administration formulated a military response to the September attacks in a climate of strong domestic and international support. The organization of military forces for OEF was conducted through a process U.S. Secretary of State Powell described as the "variable geometry" of coalition-building. This approach attempted to build a broad coalition of states by tailoring the participation of each state according to actions they were both willing and able to take. ${ }^{50}$ The result of these efforts was a "coalition of coalitions," each tailored to particular aspects of the GWOT and made up of different groups of state and non-state actors. The emerging series of diplomatic and military coalitions gave the United States the access to international resources without sacrificing control over the scope and pace of operations. One set of analysts observed, "Washington refused to cede any degree of control or even any right of consultation. Assistance offered under even an implicit notion that participation conferred some such rights was refused."

Thus, rather than asking the NAC to organize a CJTF for deployment into Afghanistan, American leaders asked individual allies to provide specific assets for an American-led military campaign. NATO member states would make important contributions to the military coalition, along with other key American allies. The United States formed a military coalition for OEF based on the capability of allied forces, their

\footnotetext{
${ }^{50}$ Woodward, Bush at War, 49.

${ }^{51}$ Philip Gordon and Jeremy Shapiro, Allies at War: America, Europe and the Crisis in Iraq (New York:McGraw-Hill, 2004), 64.
} 
demonstrated interoperability with the American military, and the size and location of support facilities. Many of the states bordering Afghanistan had little to offer in the way of military forces, but provided transportation routes and access to bases that would be crucial to the campaign. President George W. Bush remarked, "Together, we're building a very strong coalition against terror. And NATO is the cornerstone of that coalition. But I want to remind my fellow citizens, the coalition goes way beyond NATO." ${ }^{, 2}$ In the end, and the abundance of support pledged by other states and international organizations allowed American leaders to organize a collective military response on terms most favorable to their interests. Successful diplomatic efforts combined with America's military preponderance resulted in an approach to coalition operations where, as Bush administration officials frequently observed, "The mission has determined the coalition; the coalition has not determined the mission." ${ }^{53}$

\section{NATO Support for Operation Enduring Freedom}

President George W. Bush made it clear from the beginning that the United States would seek to retaliate against any state or non-state actor linked to the attacks. In his address to the nation on September 11, 2001, President Bush declared, "We will make no distinction between the terrorists who committed these acts and those who harbor them. ${ }^{, 54}$ As the evidence mounted against Al Qaeda and the Taliban, the administration

\footnotetext{
${ }^{52}$ White House Office of Press Secretary. "Remarks by the President and NATO Secretary General Lord Robertson in Photo Opportunity, October 10, 2001," http://www.whitehouse.gov/news/releases/2001 /10/20011010-6.html.

${ }^{53}$ Woodward, Bush at War, 81.

${ }^{54}$ White House Office of Press Secretary. "The President in His Address to the Nation, September 11, 2001, http://www.whitehouse.gove/news/releases/2001/09/2001/20010911-16.html.
} 
clarified the objectives of a military response. Their primary objective was to capture or kill the senior leadership of Al Qaeda in order to prevent them from carrying out future attacks. Previous attempts to disrupt Al Qaeda had involved cruise missile strikes against Al Qaeda facilities, as the United States had done following an investigation into the bombing of American embassies in Africa in 1998. President Bush felt the scope of the most recent attacks justified a far more aggressive military response. He told members of his cabinet, "I don't want to use a million dollar missile to destroy a five dollar tent." The current administration envisioned military operations of greater scope and intensity than previous attempts to target the leadership of Al Qaeda. These operations would seek to coerce the Taliban to cooperate with operations against Al Qaeda or drive the Taliban from power.

This policy was clarified during the President's address to Congress on September 20,2001 when he called for all states to abandon the practice of sponsoring terrorism. President Bush stated, "We will pursue nations that provide aid or safe haven to terrorism. Every nation, in every region, now has a decision to make. Either you are with us, or you are with the terrorists. From this day forward, any nation that continues to harbor or support terrorism will be regarded by the United States as a hostile regime." 56 He made several demands on the Taliban government, demanding that they "Deliver to United States authorities all the leaders of Al Qaeda who hide in your land. Release all foreign nationals, including American citizens, you have unjustly imprisoned.

\footnotetext{
${ }^{55}$ Woodward, Bush at War, 100.

${ }^{56}$ White House Office of Press Secretary, "Joint Address to Congress and the American People, September 20, 2001, http://www.whitehouse.gove/news/releases/2001/09/2001/20010920-8.html.
} 
Protect journalists, diplomats and aid workers in your workers in your country. Close immediately and permanently every terrorist structure. Give the United States full access to terrorist training camps, so we can make sure they are no longer operating. These demands are not open to negotiation or discussion. The Taliban must act, and act immediately. They will hand over the terrorists, or they will share in their fate." ${ }^{, 57}$ The Taliban's refusal to comply with the American ultimatum led to the imminent outbreak of hostilities.

The invasion of Afghanistan by large numbers of Western troops presented a number of difficulties that American military planners hoped to avoid. These planners did not wish to repeat the mistakes of foreign powers that had attempted to invade and occupy Afghanistan in the past. Afghanistan endured many foreign occupations throughout its history. Persian, Russian and British invasions all served to unify Afghans against the invading powers. Feuding factions repeatedly came together to conduct successful guerilla campaigns to drive out invaders. A large invasion force risked resurrecting the traditional Afghan hatred of foreign invasion and giving the Afghan people a reason to rally around the Taliban. Such a force would also require a great deal of time to organize and deploy, making a covert operations strategy of providing assistance to existing insurgencies within Afghanistan preferable to a conventional ground invasion as a relatively quick and inexpensive means of achieving the administration's objectives.

${ }^{57}$ Ibid. 
The United States provided the majority of forces for OEF, as would be expected in a campaign initiated by American leaders and conducted under the oversight of an American combatant command. The nature of the chosen strategy limited the necessity for large deployments of ground troops, which allowed the United States to mobilize National Guard and Reserve forces at much lower levels than during Operation Desert Storm ten years earlier. American troop deployments peaked during at around 50,000 troops in the region (approximately 4,000 of which were operating inside of Afghanistan) during the ground offensive in November 2001. ${ }^{58}$ Although American intelligence and SOF personnel were only a small fraction of the deployed ground forces, their contribution to the outcome was disproportionate to their numbers. According to one estimate, only about 110 CIA advisors and 316 U.S. SOF personnel were sent to Afghanistan to advise opposition forces and direct coalition airpower. ${ }^{59}$ These personnel were joined by a small number of SOF units from NATO member states.

Those NATO member states possessing significant numbers of SOF personnel available to serve alongside American units willingly offered them to the coalition. Great Britain, Germany, Canada, Turkey, Denmark and France all deployed SOF forces to Afghanistan during OEF. The number of SOF personnel contributed by each state numbered in the tens rather than hundreds, but were complemented by larger contingents of conventional troops held in reserve or employed in support functions. The overall numbers of NATO allied troops participating in OEF climbed into the thousands during

\footnotetext{
${ }^{58}$ White House Office of Press Secretary, "Operation Enduring Freedom: One Year of Accomplishments, 7 October 2002," http://www.whitehouse.gov/infocus/defense/enduringfreedom.html

${ }^{59}$ Woodward, Bush at War, 314 and 329.
} 
the first few months of the campaign. Great Britain and Canada each made contributions of between 1,700 and 2,500 troops, forming national contingents of troops operating under the direction of U.S. Central Command. Germany, France and Spain also sent sizeable contingents to the region. Even smaller NATO member states such as Norway and the Czech Republic managed to deploy specialized units to the coalition for specific missions such as reconnaissance and landmine removal. ${ }^{60}$

The coalition air campaign was dominated by American airpower, with NATO allies providing additional forces in a complementary role. Approximately 400 U.S. aircraft managed to conduct about 100 combat sorties a day for the first several weeks of the campaign. ${ }^{61}$ These forces were supported by American reconnaissance and refueling aircraft, including several unmanned aerial systems. The number of sorties flown by American aircraft in OEF was higher than that of either ODF or OAF. U.S. aircraft flew approximately 25,000 sorties between November 2001 and January 2002, dropping roughly 18,000 bombs, including 10,000 precision munitions. ${ }^{62}$

American airpower was complemented by the deployment of nearly 100 aircraft from other NATO member states. ${ }^{63}$ France made the single greatest allied contribution to the air campaign during OEF, deploying numerous reconnaissance aircraft and tankers,

\footnotetext{
${ }^{60}$ Global Security, "Operation Enduring Freedom - Order of Battle," http://www.globalsecurity.org/ military/ops/enduring-freedom_orbat-01.htm

${ }^{61}$ Ibid.

${ }^{62}$ Michael E. O’Hanlon, “A Flawed Masterpiece," Foreign Affairs 81, no. 3 (May-June 2002): 47.

${ }^{63}$ Global Security, "Operation Enduring Freedom - Order of Battle," and Nora Bensahel , The Counterterror Coalitions: Cooperation with Europe, NATO, and the European Union (Santa Monica, CA, RAND: 2003), Appendix A.
} 
along with strike aircraft from the French aircraft carrier Charles de Gaulle and Mirage 2000 fighters operating out of Kyrgyzstan. French forces flew approximately ten percent of the combat sorties during the first three phases of OEF, and played an important role in support of coalition SOF units during Operation Anaconda in the spring of 2002. In the first year of OEF, French pilots logged 12,000 flying hours and destroyed 33 targets linked to Taliban or $\mathrm{Al}$ Qaeda. ${ }^{64}$ Great Britain provided strike aircraft along with a small number of tankers, reconnaissance, and transport aircraft. Canada deployed several reconnaisance and transport aircraft and participated in homeland defense operations under the North American Air Defense Command (NORAD) by placing CF-18 fighters on patrol throughout the country. ${ }^{65}$ Denmark, Germany, Italy, the Netherlands, Norway, and Spain all contributed transport aircraft, which lessened the burden on American air transport assets. Norway, the Netherlands, and Denmark formed a detachment of 18 F-16 fighters to provide air support for ground forces operating in Afghanistan. This detachment, designated the European Participating Air Forces (EPAF), logged nearly 4500 flying hours during the first year of OEF. ${ }^{66}$

On October 8, 2001 NATO leaders announced that Airborne Warning and Control System (AWACS) aircraft would be sent to the United States to help patrol U.S. airspace in the first operational deployment of European military forces to the United States in the

\footnotetext{
${ }^{64}$ Embassy of France in the United States, "National Defense Update, 7 April 2005," http://www.ambafrance-us.org/atoz/defense.asp.

${ }^{65}$ Canadian Ministry of National Defense, "Backgrounder: The Canadian Forces' Contribution to the International Campaign Against Terrorism, January 7, 2001," http://www.forces.gc.ca/site/Newsroom/ view_news_e.asp?id=490.

${ }^{66}$ Roar Sundseth , "The War on Terrorism: A Norwegian's Perspective," CENTCOM Coalition Bulletin, no. 2 (November 2002): 8.
} 
history of the Alliance. These aircraft were part of the NATO Airborne Early Warning Force (NAEWF) that had been jointly manned and funded by the allies since 1980 . NAEWF was made up of aircraft based in Germany and Great Britain, serving under the command of SHAPE and currently conducting monitoring missions in support of SFOR and KFOR. French AWACS were sent to the Balkans in order to backfill the NATO AWACS transferred to NORAD to aid in the monitoring of American airspace for several months. The deployment was given the name Operation Eagle Assist and consisted of sending five AWACS aircraft and their aircrews to Tinker Air Force Base in Oklahoma. Personnel from thirteen NATO member states participated in Operation Eagle Assist flying over 4300 hours in approximately 360 operational sorties between October 2001 and May 2002, which made up approximately twenty five percent of the AWACS patrols during this period. ${ }^{67}$

Three U.S. Navy carrier battle groups played a large role throughout the initial phases of the conflict. The USS Roosevelt served as the hub for naval operations in the theater, with the commander of the carrier battle group also providing direction to coalition naval forces. In addition to serving as a platform for U.S. Navy aircraft conducting airstrikes in Afghanistan, the USS Kittyhawk served as a forward operating base for SOF troops. While the United States once again had the largest naval force deployed to the region, NATO allies established an important presence in both the Arabian and Mediterranean Seas. At the peak of the campaign, there were more than 80 coalition naval vessels deployed in the Arabian Sea.

\footnotetext{
${ }^{67}$ NATO Office of Information and Press, "Statement by the Secretary General on the Conclusion of Operation Eagle Assist, April 30, 2002," http://www.nato.int/docu/update/2002/04-april/e0430a.htm.
} 
The U.S. Navy was joined in the Arabian Sea by ships from several NATO allies including Great Britain, Canada, France, Germany, Greece, Italy, the Netherlands, and Spain. The British navy played an important role in OEF from the very beginning, with three Royal Navy submarines launching cruise missiles against targets in Afghanistan on October 7, 2001 and then again six days later. Great Britain also deployed a naval task force to the region, led by the aircraft carrier, the HMS Illustrious. French naval assets in the region included a frigate, supply ship, two minehunters, and a mobile support vessel. Italy also contributed its carrier battle group, later relieved by a destroyer and a frigate. ${ }^{68}$ Canada deployed a naval task group comprised of three frigates, a destroyer and a supply ship to operate alongside the American carrier battle groups in the region. ${ }^{69}$ Coalition navies monitored commercial sea lanes, boarding suspicious vessels and escorting coalition boats through the Arabian Sea. As the Taliban lost control of Afghanistan and Al Qaeda members began seeking refuge elsewhere, NATO vessels began naval patrols off the coast of Somalia. Germany dispatched a seven-ship naval force for this purpose, which coordinated its efforts with French and British aircraft conducting surveillance flights over the country. ${ }^{70}$

The NAC approved Operation Active Endeavor as an adjunct to OEF on October 26, 2001, calling for the movement of the Alliance's Standing Naval Forces

\footnotetext{
${ }^{68}$ U.S. Central Command, "International Contributions to the War on Terrorism," http://www.centcom.mil/ Operations/Coalition/joint.htm.

${ }^{69}$ Canadian Ministry of Foreign Affairs and International Trade, "Backgrounder: Canada's Action Against Terrorism Since September 11, January 3, 2002," http://www.dfait-maeci.gc.ca/anti-terrorism/ canadaactions-en.asp.

${ }^{70}$ Thomas Ricks, “Allies Step Up Somalia Watch; U.S. Aims to Keep Al Qaeda at Bay," The Washington Post, January 4, 2002.
} 
Mediterranean (STANAVFORMED) from the Western to Eastern Mediterranean Sea.

STANAVFORMED consisted of nine ships, forming "the nucleus around which to build a more versatile and powerful naval force, whenever required." ${ }^{71}$ Operation Active Endeavor pre-positioned NATO naval forces in the event that they were needed to support any expansion of the campaign in Afghanistan. STANAVFORMED also monitored commercial shipping in the area, reserving the right to intercept and board any ships suspected of transporting or supporting terrorists. Shared interest in keeping the Mediterranean's busy trade routes open and secure gave Operation Active Endeavor a mandate that extended well beyond the fall of the Taliban in Afghanistan. After an initial six month deployment, a rotation schedule was worked out with NATO's Standing Naval Force Atlantic (STANAVFORLANT) enabling a NATO presence to be extended indefinitely and adding escort duties for ships passing through "choke points" in and around the Mediterranean Sea. ${ }^{72}$

Ground, air, and naval forces from NATO member states clearly contributed to the success of OEF, although their presence was not decisive to the outcome of the campaign. While NATO forces demonstrated their ability to work together effectively under American leadership, the campaign was not conducted without some conflict among the allies. In the absence of a multinational command structure, French participation in OEF was only approved on a case-by-case basis. Prime Minister Lionel

\footnotetext{
${ }^{71}$ NATO Office of Information and Press, "NATO Naval Force Deploys to Eastern Mediterranean, October 9, 2001," http://www.nato.int/docu/update/2001/1008/e1009a.htm.

${ }^{72}$ Operation Active Endeavor would eventually be expanded to include the escort of non-military ships through the Strait of Gibralter. This operation remains active and continues to contribute to the peaceful flow of commercial shipping throughout the Mediterranean.
} 
Jospin emphasized, "France's participation in new operations necessitates our full involvement in the definition of the objectives and military planning and, with respect to our own forces, our approval of them,"73 While cooperation among participating NATO forces was continually improving throughout OEF, the unease of some NATO leaders with an American-led command structure begs the question of how long the collective effort could have been maintained had major difficulties been encountered during the ground offensive. The fall of the Taliban by the end of 2001 presented American and European leaders with an opportunity to reflect on the progress of recent counterterrorism operations and to decide where to proceed next in the ongoing effort to reduce the threat posed by international terrorism and the proliferation of WMD. NATO's Role in Stabilization and Reconstruction Operations in Afghanistan

Alliance officials began preparations for some level of participation in postconflict stability operations in Afghanistan during the early days of OEF. These preparations were an outgrowth of the invocation of Article Five of the North Atlantic Treaty on October 4, 2001, and the NAC's agreement to “provide, individually or collectively, as appropriate and according to their capabilities, assistance to allies and other states which are or may be subject to increased terrorist threats as a result of their support for the campaign against terrorism." ${ }^{74}$ Given the Alliance's experience in peace

\footnotetext{
${ }^{73}$ French Mission to United Nations, "Replies by M. Lionel Jospin, Prime Minister, to Questions in the National Assembly, November 6, 2001, http://www.un.int/france/documents_anglais/011106_mae_ jospin_asie.htm.

${ }^{74}$ NATO Office of Information and Press, "Statement to the Press By NATO Secretary General Lord Robertson of the North Atlantic Council Decision on Implementation of Article 5 of the Washington Treaty Following the 11 September Attacks Against the United States, October 4, 2001," http://www.nato.int/ docu/speech/2001/s01 1004b.htm.
} 
operations, NAC formally tasked NATO's military authorities on November 13, 2001 with preparing contingency plans for possible humanitarian operations in and around Afghanistan. NATO Secretary General Robertson later emphasized the suitability of NATO experience and capabilities to the situation in Afghanistan, stating "NATO has a vital role - in my view, the vital role - to play in multinational crisis prevention and crisis management." ${ }^{75}$ NATO's experience in the Balkans had resulted in numerous initiatives that could be replicated in future peace operations, including the formation of civilmilitary coordination centers and the dissemination of common doctrine suitable to provide guidance to multinational forces.

While the participation of the United States' NATO allies in OEF merely complemented the efforts of American combat forces, these allies made more significant contributions to the stabilization and reconstruction efforts. The actions of European governments working through NATO, the EU and the UN contributed greatly to maintaining order in Afghanistan following the fall of the Taliban. These efforts included the German government's hosting of a conference of Afghan leaders to develop an interim government to lead Afghanistan's transition to democracy. European governments were also reasonably well-represented in international aid contributions to Afghanistan. During international aid conferences in Tokyo (2002) and Berlin (2004), European states accounted for around $30 \%$ of the $\$ 12.5$ billion in grants aimed at financing post-war reconstruction efforts. ${ }^{76}$ Another key contribution came with British

\footnotetext{
${ }^{75}$ Diego Ruiz, "The Road to Kabul," NATO Review 51, no. 2 (Summer 2003): 10.

${ }^{76}$ European Union Office of External Relations, "The EU's Relations with Afghanistan," http://europa.eu.int/comm/external_relations/afghanistan/intro/.
} 
agreement to organize and command a post-Taliban stabilization mission to be fielded alongside OEF coalition forces. The International Security Assistance Force was established under a UN Security council mandate, but predominantly manned by NATO member states and eventually placed under NATO command. NATO's post-war role in Afghanistan demonstrated the Alliance's continued relevance as well as an emerging distribution of labor between the United States and its NATO allies in the conduct of military interventions.

American leaders recognized the need for stabilization and peacekeeping operations in Afghanistan, but sought to keep these efforts separate from OEF. The United States intended to maintain thousands of troops in Afghanistan to kill or capture the remnants of Al Qaeda and the Taliban, and American military leaders were reluctant to see OEF transition into a peacekeeping operation. President George W. Bush strongly favored the creation of an international peacekeeping force to lessen the burden on American military forces and allow them to continue focusing on offensive operations. President Bush reportedly remarked to the NSC in the fall of 2001, "I oppose using the military for nation building. Once the job is done, our forces are not peacekeepers." ${ }^{\text {77 }}$ In December 2001 testimony before the U.S. Senate Foreign Relations Committee, Richard Haas, U.S. Department of State Director of Policy Planning, assured the committee that the United States would have a very limited role in the post-war reconstruction of Afghanistan. Haas suggested that other countries should accept most of the responsibility for rebuilding Afghanistan, because the United States was doing the "lion's share of the

\footnotetext{
${ }^{77}$ Woodward, Bush at War, 237.
} 
world's work" in OEF. ${ }^{78}$ These views were also reflected in the comments of White House Spokesperson, Ari Fleischer, when questioned about President Bush's apparent distaste for peacekeeping missions. Fleischer told reporters during a January 2002 press briefing, "The United States has a series of commitments around the world to peacekeeping that the president is honoring. The president would like, over time, to be able to draw those down so the core mission of our military can remain focused on a combat-ready force."79

In an effort to keep United States military forces focused almost entirely on offensive counter-terrorism operations, American officials turned to its NATO allies with a request that they take the lead in organizing and equipping a peacekeeping force for Afghanistan. American diplomats succeeded in adding an appeal for international assistance to the UN-sponsored Bonn Agreement, stating "Conscious that some time may be required for the new Afghan security and armed forces to be fully constituted and functioning, the participants in the U.N. talks on Afghanistan request the United Nations Security Council to consider authorizing the early deployment to Afghanistan of a United Nations mandated force. This force will assist in the maintenance of security for Kabul and its surrounding areas. Such a force could, as appropriate, be progressively expanded to other urban centers and other areas." 80 As conceived by American leaders, this

\footnotetext{
${ }^{78}$ Jonathan Wright, "U.S. outlines Limited Role in Rebuilding," Houston Chronicle, December 7, 2001.

${ }^{79}$ White House Office of Press Secretary, "Press Briefing by Ari Fleischer, January 28, 2002," http://www.whitehouse.gov/news/releases/2002/01/20020128-11.html.

${ }^{80}$ Afghan Transitional Government, “Agreement on Provisional Arrangements in Afghanistan Pending the Re-establishment of Permanent Government Institutions, Annex I: International Security Force, December 5, 2001," http://www.afghangovernment.com/AfghanAgreementBonn.htm.
} 
multinational force would be subordinate to the American-led OEF coalition, and even more significantly, virtually devoid of American troops.

The mandate for the first International Security Assistance Force to Afghanistan (ISAF I) was established by UNSCR 1386 on December 20, 2001. ISAF I consisted of approximately 5,000 troops with a mandate to "assist the Afghan Interim Authority in the maintenance of security in Kabul and its surrounding areas, so that the Afghan Interim Authority as well as the personnel of the U.N. can operate in a secure environment." ${ }^{\text {81 }}$ In addition to assisting Afghan security forces, ISAF I would complement the work of the United Nations Assistance Mission in Afghanistan (UNAMA) and other NGOs engaged in providing economic assistance throughout the country. ISAF I's limited size and mandate assured both Afghan citizens and participating governments that ISAF would not play the role of an occupying army. ISAF I troop levels were small in comparison to the tens of thousands of troops allocated to NATO-led peacekeeping and reconstruction efforts in the Balkans. ISAF I would provide much-needed security assistance to Karzai's fledgling government, but would not have the resources to complete a wholesale political and economic transformation of Afghanistan. U.S. State Department officials estimated that a peacekeeping force deployed throughout all of Afghanistan with a mandate similar to that of SFOR or KFOR would need around 25,000 troops, as compared to the 4,700 peacekeepers in Afghanistan by the spring of $2002{ }^{82}$

\footnotetext{
${ }^{81}$ United Nations Documentation Center. "United Nations Security Council Resolution 1386, December 20, 2001.” http://daccessdds.un.org/doc/UNDOC/GEN/N01/708/55/PDF/N0170855.pdf?OpenElement.

${ }^{82}$ Michael Elliott, "The Battle over Peacekeeping: As the fighting in Afghanistan Drags on, American Troops Risk Being Dragged into a Messy Civil War," Time, March 4, 2002. http://www.time.com/time/ magazine/article/0,9171,1001917,00.html.
} 
Great Britain assumed leadership of ISAF I during its crucial first six months of operations in Afghanistan. To prevent any conflict between ISAF I and OEF, American and British representatives drafted agreements wherein ISAF commanders would keep U.S. Central Command informed of their activities and allow OEF operations to take precedence over those of ISAF. ${ }^{83}$ In return, OEF coalition forces would provide logistics, airlift, communications and intelligence support for ISAF I. As lead nation, Great Britain supplied the largest number of troops, around 1,800 soldiers, and appointed officers to fill key leadership positions. As it turned out, 12 of the 18 states participating in ISAF I were NATO members, while another five were members of NATO's PfP. ${ }^{84}$ ISAF I was structured around three levels of command: ISAF headquarters in UK Permanent Joint Headquarters near London, the Multinational Brigade headquarters in Kabul and the Kabul International Airport task force. ISAF I commanders worked with the interim Afghan government to begin the process of reopening Kabul International Airport along with hundreds of other reconstruction and humanitarian aid projects.

Turkey volunteered to assume leadership of ISAF II after six months, and the change of leadership was approved by the United Nations Security Council with the passage of UNSCR $1413 .{ }^{85}$ This renewal of the mission was accompanied by the transfer

\footnotetext{
${ }^{83}$ United Nations Documentation Center, "Letter from the Permanent Representative of the UK to the President of the Security Council, 19 December 2001," http://www.un.org/News/Press/docs/ 2001/sc7248.doc.htm.

${ }^{84}$ NATO member states in ISAF I included Belgium, the Czech Republic, Denmark, France, Germany, Great Britain, Greece, Italy, the Netherlands, Norway, Portugal, Spain and Turkey. PfP member states included Austria, Bulgaria, Finland, Romania and Sweden. New Zealand was the only non-NATO participant in ISAF I.

${ }^{85}$ United Nations Documentation Center, "United Nations Security Council Resolution 1413, May 23, 2002." http://daccessdds.un.org/doc/UNDOC/GEN/N02/397/33/PDF/N0239733.pdf?OpenElement.
} 
of ISAF headquarters from its location near London to the Turkish General Staff headquarters in Ankara and a rotation of forces among participating states. The overall number of forces participating in ISAF II remained relatively stable, although some states elected to withdraw troops while others began providing troops for the first time. The vast majority of ISAF II forces continued to come from NATO member and partner states. NATO's Secretary General, lobbied hard for continued contributions from NATO member states reminding NATO members, "Whereas geography once isolated Europe and North America from the fall-out of instability in other parts of the world, this is no longer the case today. Increasingly, we must expect far-away conflicts to spill over into our societies in the form of migration, rising numbers of asylum seekers and smuggling, of humans, drugs and weapons." ${ }^{, 86}$ ISAF II continued much of the work began under ISAF I, along with increased efforts to train the Afghanistan National Army.

The rotation of forces and command responsibilities was repeated once again six months later when Germany and the Netherlands jointly agreed to lead ISAF III beginning in February 2003. This rotation marked a greater convergence between the conduct of the Afghanistan peacekeeping mission and ongoing organizational reforms within the Alliance. ISAF headquarters moved to the Bundeswehr Operational Command near Berlin, which had recently been designated a joint NATO corps headquarters for German and Dutch forces under AFNORTH. ISAF commanders exploited their status within the NATO command structure and requested planning assistance from the SHAPE staff. NAC approved their request and SHAPE helped ISAF

\footnotetext{
${ }^{86}$ George Robertson, "Investing in Security," NATO Review 50, no. 3 (Fall 2002): 8.
} 
commanders generate forces, and provided access to NATO intelligence along with communications and information systems. ${ }^{87}$

As it became apparent that the Afghanistan government's need for security assistance would continue indefinitely, the NAC debated whether SHAPE's advisory role to the lead nations directing operations in Afghanistan should be replaced by NATO's formal command of ISAF. General James Jones, NATO's Supreme Allied Commander Europe and Commander of the U.S. European Command, commented on SHAPE's suitability to command ISAF, stating "It's not a classic NATO mission, but the key countries involved are NATO members and they are using NATO terminology, NATO procedures and NATO capabilities. In the event of crises that are humanitarian in nature or require peacekeeping, NATO has proven that it can deal with them. ${ }^{\wedge 8}$ NATO command would provide greater stability and predictability to ISAF operations by eliminating the need to search for a new lead nation and transfer operations to a new headquarters every six months. As an additional benefit, the existence of a standing headquarters would encourage greater participation by smaller NATO member and partner states that were willing to contribute personnel, but unable to assume all of the responsibilities of a lead nation.

By the fall of 2003, the NAC agreed to assume responsibility for the command, coordination and planning of future ISAF missions. NATO General Secretary Robertson lobbied hard for NATO leadership of ISAF IV, arguing "All of [our] members

\footnotetext{
${ }^{87}$ Diego Ruiz, “Afghanistan's Transformational Challenge,” NATO Review 53, no. 2 (Summer 2005) http://www.nato.int/docu/review/2005/issue2/english/art2.html.

88 “Interview with General James L. Jones, SACUER," NATO Review 51, no. 1 (Spring 2003): 24.
} 
understand and agree that if we do not go to Afghanistan, and succeed in Afghanistan, Afghanistan and its problems will come to us. Worse still, we would have to deal with the terrorists, the refugees and the drug traffickers with a much weaker international security structure because NATO would have been severely damaged and the concept of multinational security cooperation, whether in NATO, the European Union, the United Nations or coalitions, would have been dealt an equally heavy blow." ${ }^{89}$ Rather than transferring command of ISAF IV to Canada as planned in August 2003, the NAC appointed a Canadian general officer as the Joint Force Commander for the NATO-led mission along with a multinational staff drawn from participating states. Although continuing to operate under a UN mandate, the NAC would provide direction to participating forces from both NATO member and non-member states. Under revisions to NATO's organizational structure, all military operations would receive strategic guidance from Allied Command Operations (ACO), headquartered at SHAPE. Joint Force Command (JFC) Brunssum in the Netherlands, one of two NATO JFCs, provided operational command for ISAF to include manning, training, and deployment of ISAF personnel. Within Afghanistan, the Kabul Multinational Brigade headquarters provided tactical direction to ISAF IV forces organized into three battle groups. While NATO once again demonstrated its utility as a resource for the organization and command of multinational forces, this effort was limited to peacekeeping and reconstruction activities. Offensive counter-terrorism operations would continue to be conducted by the Americanled international coalitions deployed first in Afghanistan and later in Iraq.

\footnotetext{
${ }^{89}$ George Robertson, "Change and Continuity," NATO Review' 51, no 3 (Winter 2003): 3.
} 


\section{Confronting Iraq Over Alleged WMD Development}

As conditions stabilized in Afghanistan in early 2002, the United States became more concerned with the perceived threat posed by Iraq and other "rogue states" that continued to pursue WMD programs and provide support for international terrorist groups. Initial attempts to establish a link between Iraq and the September 2001 attacks had proven unfruitful. Secretary of State Colin Powell cautioned that there was no evidence that Iraq had been directly involved in the attacks using this event to justify an invasion of Iraq could undermine international support. Powell reportedly told President Bush in the fall of 2001, "They [the coalition partners] will view it as bait and switch it's not what they signed up to do." ${ }^{90}$ Even Vice President Cheney recognized that world opinion did not favor an attack on Iraq at that time, noting "If we go after Saddam now, we lose our rightful place as the good guy."91 The Bush administration decided to emphasize the danger posed by Iraq's continued possession of WMD as part of an effort to further isolate Iraq and create more favorable conditions for a future confrontation with Iraq.

President Bush's January 2002 State of the Union speech described the risk posed by states that continued to provide support to terrorist groups while disregarding international nonproliferation accords. The President expressed a renewed emphasis on a strategy of preemption, noting "I will not wait on events, while dangers gather. I will not stand as peril draws closer and closer. The United States of America will not permit the

\footnotetext{
${ }^{90}$ Woodward, Bush at War, 87-91.

${ }^{91}$ Ibid, 25.
} 
world's most dangerous regimes to threaten us with the world's most destructive weapons." 92 The Bush administration's policy of preemption was rooted in recommendations assembled through studies conducted within the Department of Defense under Secretary Cheney's leadership in the early 1990s. Cheney's Defense Strategy for the 1990s advocated the continued growth of American military power to preserve the United States global dominance. The study recommended that American military forces strive for the capability to launch preemptive attacks on states seeking to develop weapons of mass destruction. While this study emphasized the existence of proliferation concerns among a large number of states, President Bush expressed a particular concern for the activities of Iraq, Iran and North Korea. Bush stated, "States like these, and their terrorist allies, constitute an axis of evil, arming to threaten the peace of the world. By seeking weapons of mass destruction, these regimes pose a grave and growing danger." 93

The Bush administration promoted its strategy of preemption throughout 2002, making it clear that this strategy applied not only to counter-terrorism operations, but could also be used to justify attacks on sovereign states. During his commencement speech to the United States Military Academy at West Point in June 2002, President Bush argued that the right of self-defense should be extended in order to authorize pre-emptive attacks against potential aggressors before they are able to launch strikes against the United States. He pointed out the shortfall of other strategies, noting "Deterrence means

\footnotetext{
${ }^{92}$ White House Office of Press Secretary, "President Delivers State of the Union Address," January 29 , 2002. http://www.whitehouse.gov/news/releases/2002/01/20020129-11.html

${ }^{93}$ Ibid.
} 
nothing against shadowy terrorist networks with no nation or citizens to defend.

Containment is not possible when unbalanced dictators with weapons of mass destruction can deliver those weapons on missiles or secretly provide them to terrorist allies. We cannot defend America and our friends by hoping for the best... our security will require all Americans to be forward-looking and resolute, to be ready for preemptive action when necessary to defend our liberty and to defend our lives." ${ }^{, 4}$ In September, 2002, the Bush administration further described its policy of preemption in its first update to the National Security Strategy of the United States. The NSS stated "We must be prepared to stop rogue states and their terrorist clients before they are able to threaten or use WMD against the U.S. and out allies and friends... While the United States will constantly strive to enlist the support of the international community, we will not hesitate to act alone, if necessary, to exercise our right of self-defense by acting preemptively against such terrorists, to prevent them from doing harm against our people and our country." 95

The Bush administration's attempts to increase international support for a preemptive strike against Iraq included appeals to both the United Nations and NATO. In the fall of 2002, the United States crafted a new Security Council resolution authorizing the use of force in Iraq. President Bush's speech to the United Nations on September 12, 2002 challenged the UN to enforce Iraqi disarmament pledges. He asked, "Are Security Council resolutions to be honored and enforced, or cast aside without consequence? Will the United Nations serve the purpose of its founding or will it be

\footnotetext{
${ }^{94}$ White House Office of Press Secretary, "President Delivers Graduation Speech at West Point," June 1, 2002. http://www.whitehouse.gov/news/releases/2002/06/20020601-3.html

${ }^{95}$ White House Office of Press Secretary, The National Security Strategy of the United States of America (Washington D.C.: White House, 2002), 15.
} 
irrelevant?"96 The United States succeeded in prodding the UN into action, but was unable to gain unequivocal support for the use of force against Iraq. Instead, the Security Council passed a UNSCR 1441, giving Iraq a "final opportunity" to comply with the disarmament and inspection provisions specified in previous resolutions or face "serious consequences." 97

American officials also explored ways of further improving NATO's ability to participate in out-of-area operations upon short notice. Acting on lessons learned during military operations in Afghanistan, American officials introduced a number of reforms for consideration during the next NATO summit scheduled for November. U.S. Defense Secretary Donald Rumsfeld proposed the organization of a standing NATO Reaction Force (NRF) in order to have forces on hand for short-notice deployments, as had been required the previous fall. NRF was envisioned as a "technologically advanced, flexible, deployable, interoperable and sustainable force including land, sea, and air elements ready to move quickly to wherever needed, as decided by the Council." 98 This force would have the ability to perform the full spectrum of military missions related to peacekeeping and peace enforcement, ranging from humanitarian relief operations to high-intensity combat operations. These troops would be maintained at a high state of

\footnotetext{
${ }^{96}$ White House Office of Press Secretary, "Remarks by the President in Address to the United Nations General Assembly, September 12, 2002," http://www.whitehouse.gov/news/releases/2002/09/200209121.html.

${ }^{97}$ United Nations Documentation Center. "United Nations Security Council Resolution 1441, November 8, 2002." http://daccessdds.un.org/doc/UNDOC/GEN/N02/682/26/PDF/N0268226.pdf?OpenElement.

98 NATO Office of Information and Press, "Prague Summit Declaration Issued by the Heads of State and Government Participating in the Meeting of the North Atlantic Council in Prague, November 21, 2002," http://www.nato.int/docu/pr/2002/p02-127e.htm.
} 
readiness so that they could begin deploying within five days of a request with the capability of sustaining operations for up to 30 days without outside assistance. It was estimated to require roughly two years to organize, train and equip an initial NRF brigade, with the full operational capability of the NRF to be achieved within four years. A fully operational NRF force of 20,000 was envisioned to consist of multiple brigades, each consisting of ground, air and maritime forces along with command and support elements for independent out-of-area operations. ${ }^{99}$

A second initiative introduced at the Prague Summit was the declaration of a new commitment to improve the capabilities of NATO militaries to enhance their combat effectiveness. The Prague Capabilities Commitment (PCC) was intended to address shortfalls in the counter-terrorism capabilities of many NATO militaries by enabling them to deploy faster and to be sustained for longer periods far from their home bases. Operational shortfalls were identified for particular emphasis in the areas of chemical, biological, radiological, and nuclear defense; intelligence, surveillance, and target acquisition; air-to-ground surveillance; command, control and communications; combat effectiveness, including precision guided munitions and suppression of enemy air defenses; strategic air and sea lift; air-to-air refueling; and deployable combat support and combat service support units. ${ }^{100}$ Initial expectations were that PCC would quadruple the number of large transport aircraft operated by European member states, establish an

\footnotetext{
${ }^{99}$ The first operational deployment of the NRF took place in October 2005 when the NAC agreed to provide humanitarian relief to Pakistan following a large earthquake. The NRF consisted of forces from several NATO countries equipped to provide food, shelter, and medical care for thousands of Pakistani civilians for up to six months.

${ }^{100}$ NATO Office of Information and Press, "Prague Summit Declaration Issued by the Heads of State and Government Participating in the Meeting of the North Atlantic Council in Prague, November 21, 2002."
} 
interoperable pool of tankers, and increase the stock of precision-guided munitions among European air forces by forty percent. ${ }^{101}$

In an attempt to assure a high level of compliance with the pledges made as part of PCC, each state was asked to specify the capability improvements that it would pursue, either alone or with other member states. Germany agreed to lead a consortium to explore options for improving NATO's airlift capacity, to include proposals to lease a number of transport aircraft in the short term. The Netherlands led an effort to explore additional munitions purchases on part of several NATO governments. Spain accepted the responsibility for crafting an lease arrangement for up to 100 tanker aircraft. Several states, including Canada, France, Italy, the Netherlands, Spain, and Turkey all agreed to upgrade their intelligence and surveillance capabilities through the acquisition of unmanned aerial vehicle systems. ${ }^{102}$ NATO General Secretary George Robertson, noted, "Many allies are committed to making improvements individually, others to forming teams to address shortfalls more effectively. But importantly, all these commitments are clear and specific - which will make it easy to monitor progress. In this way, the Prague Capabilities Commitment marks a real turning point in the adaptation of European capabilities to the requirements of the 21 st century."103

While some discussions were held on the increased tensions over Iraq during and after the Prague Summit, little progress was made on determining the Alliance's role in

\footnotetext{
${ }^{101}$ Christopher Bennett, “Combatting Terrorism," NATO Review 51, no I (Spring 2003): 6.

${ }^{102}$ White House Office of Press Secretary, "Fact Sheet, "NATO: Building New Capabilities for New Challenges, November 21, 2002," http://www.whitehouse.gov/news/releases/2002/1 1/20021 121-6.html.

${ }^{103}$ George Robertson, "Transforming NATO," NATO Review 51, no. 1 (Spring 2003): 3.
} 
the crisis. When asked in September 2002 about approaching NATO to organize and command a multinational force for the invasion of Iraq, U.S. Secretary of State Donald Rumsfeld replied, "I can't imagine it...I have no idea, it hasn't crossed my mind, we've not proposed it." ${ }^{104}$ A declaration was issued during the summit expressing the support of NATO governments for the terms laid out in UNSCR 1441. This declaration stated, "We support the goal of the international community for full disarmament of Iraq as stipulated in the UN Security Council Resolution 1441. In the event of non-compliance with the terms of this resolution, we are prepared to contribute to an international coalition to enforce its provisions and the disarmament of Iraq." ${ }^{05}$ NATO's relationship to such a coalition was left unresolved, with many leaders clearly hopeful that the crisis would pass before such a coalition would have to be formed.

U.S. Deputy Secretary of Defense Paul Wolfowitz visited NATO headquarters in December 2002 to formally request that the Alliance prepare to provide support to the United States and Turkey in the event of war with Iraq. Alliance officials were asked to consider sending AWACS aircraft, Patriot missile defense units, and chemical and biological warfare detection units to Turkey; to direct NATO naval forces to aid in the defense of American ships in the Mediterranean Sea, to provide allied troops to defend American military bases in Europe and possibly the Persian Gulf; to further offset reductions in the United States military forces participating in NATO peacekeeping missions; and to assist with postwar reconstruction and peacekeeping. After several

\footnotetext{
${ }^{104}$ U.S. Department of Defense, "Secretary Rumsfeld Media Availability En Route to Poland, September 22, 2002," http://www.defense.gov/transcripts/2002/t09232002_t0922sd.html.

${ }^{105}$ NATO Office of Information and Press, "Summit Declaration on Iraq, November 21, 2002," http://www.nati.int/docu/comm/2002/0211-prague/index.htm
} 
weeks of discussion among subordinate planning bodies, these proposals were rejected in light of opposition from several NATO governments. Representatives of France, Germany, and Belgium all felt that it was premature to begin such planning while UN inspectors were still in the process of assessing Iraq's compliance with UNSCR 1441. While American requests for assistance were soon rescinded, the question of the Alliance's responsibility to aid in the defense of Turkey continued to be pursued.

The NAC was forced to reconsider the issue when Turkey invoked Article Four of the North Atlantic Treaty. This article obliges NATO member states to "consult together whenever, in the opinion of any of them, the territorial integrity, political independence or security of any of the Parties is threatened." 106 Despite the added gravity of the request provided by Turkey's reference to Article Four and the removal of American appeals for NATO troop contributions, France, Belgium, and Germany once against voiced their opposition and denied the request. Belgian Foreign Minister Louis Michel summarized their concerns, stating that any concrete measures to provide for Turkey's defense "would signify that we have already entered into the logic of war... [and] any initiative to still resolve the conflict in a peaceful way was gone."107 American officials were both surprised and angered by the willingness of some member states to shirk what they believed to be the Alliance's collective-defense responsibilities to Turkey, prompting U.S. Secretary of State Colin Powell to observe, "The Alliance is breaking

\footnotetext{
${ }^{106}$ NATO Office of Information and Press, "The North Atlantic Treaty, April 4, 1949," http://www.nato.int/docu/basictxt/treaty.htm.

${ }^{107}$ Paul Ames, "France, Germany, Belgium Block NATO Plans to Protect Turkey," Associated Press, February 10, 2003.
} 
itself up because it will not meet its responsibilities."108 NATO Secretary General Lord Robertson attempted to be more upbeat, observing that "there is complete agreement among NATO countries about their commitment to defend Turkey, and on the substance of the planning measures" but that "there has been a disagreement is over when to formally task this military planning. Not whether to plan but when to plan." 109

The deadlock in the NAC was overcome the Secretary General's use of a procedural maneuver that allowed the debate to be transferred to NATO's Defense Planning Committee (DPC). The DPC was composed of representatives from all NATO member countries except France, who had left the committee as part of its military realignment in 1966. Lengthy discussion within the committee eventual resulted in the agreement of Germany and Belgium to allow NATO to provide limited assistance to Turkey. The resulting compromise specified that NATO's assistance "relates only to the defense of Turkey" and would not obligate the Alliance to provide additional support for a future invasion of Iraq. ${ }^{110}$ Operation Display Deterrence began the day after an agreement was made, and consisted of the deployment of NATO AWACS aircraft to Turkey along with Patriot missile defense batteries and units specializing in the detection of chemical and biological agents.

NATO member states remained divided in their views regarding the necessity for a confrontation with Iraq over its alleged WMD programs. While U.S. public opinion in

\footnotetext{
${ }^{108}$ Julia Preston and Steven Weisman, "France Offering Plan to Expand Iraq Arms Hunt," The New York Times, February 12, 2003.

${ }^{109}$ NATO Office of Information and Press, "Statement by the Secretary General on the North Atlantic Council Meeting, February 6, 2003," http://www.nato.int/docu/speech/2003/s030206a.htm.

110 "NATO Blocked on Iraq Decision," The Washington Post, January 23, 2003.
} 
the latter part of 2002 supported military action against Iraq, European public opinion tended only to support military action only in the context of another UNSCR. Chancellor Schroeder's concern over growing anti-war sentiment led him promise that Germany would decline to participate in any military operation in Iraq, even if such an operation were authorized by the UN Security Council. He further promised to withdraw German troops stationed in Kuwait in the event of an American attack on Iraq. U.S. Secretary of Defense Donald Rumsfeld challenged characterizations of blanket opposition to the use of force among European governments, stating "Germany has been a problem and France has been a problem, but if you look at the vast majority of other countries in Europe, they're not with France and Germany...You're thinking about Europe as Germany and France. I don't. I think that's 'old Europe.' If you look at the entire NATO Europe today, the center of gravity is shifting to the east." found themselves leading a group of NATO governments on one side of the debate with Great Britain, Spain, Italy, among those states supporting the United States. On January 30, 2003 eight European NATO heads of state issued an open letter of support for U.S. policy toward Iraq. ${ }^{112}$ The letter acknowledged past American contributions to European security and cautioned, "The trans-Atlantic relationship must not become a casualty of the current Iraqi regime's persistent attempts to threaten world security. In today's

\footnotetext{
${ }^{111}$ U.S. Department of Defense, "Secretary Rumsfeld Briefs at the Foreign Press Center, January 22, 2003," http://www.defenselink.mil/news/Jan2003/t01232003_t0122sdfpc.html.

112 The NATO states represented in this effort included Great Britain, the Czech Republic, Hungary, Italy, the Netherlands, Poland, Portugal, and Spain.
} 
world, more than ever before, it is vital that we preserve that unity and cohesion." 113 These leaders further stated, "We must remain united in insisting that his regime is disarmed...The solidarity, cohesion and determination of the international community are our best hope of achieving this peacefully. Our strength lies in unity."114

The vast majority of new and prospective NATO members from Eastern and Central Europe also aligned themselves with the United States. Shortly after the publication of the first letter of support from eight NATO governments, a group of ten aspiring NATO governments declared their support for the American position on Iraq. The governments of Albania, Bulgaria, Estonia, Croatia, Latvia, Lithuania, Macedonia, Romania, Slovakia, and Slovenia published a letter stating, "Our countries understand the dangers posed by tyranny and the special responsibility of democracies to defend our shared values. The trans-Atlantic community, of which we are a part, must stand together to face the threat posed by the nexus of terrorism and dictators with weapons of mass destruction."115 The support provided by these governments to the United States was widely acknowledged to encourage American enthusiasm for further NATO expansion. One scholar observed, "In the east, it seems that much of the political class

\footnotetext{
${ }^{113}$ Jose Maria Aznar, Jose-Manuel Durao Barroso, Silvio Berlusconi, Tony Blair, Vaclav Havel, Peter Medgyessy, Leszek Miller, and Anders Fogh Rasmussen, "European Leaders in Support of U.S.," Wall Street Journal, January 30, 2003.

${ }^{114}$ Ibid.

${ }^{115}$ NATO Office of Information and Press, "Statement of the Vilnius Group Countries, February 5, 2003," http://www.nato.int/romania/vilgroupowel.htm.
} 
believes that ensuring the continued American presence in Europe is more important than lack of public enthusiasm for one particular war."116

The division among NATO governments was reflected in the UN Security Council. American leaders remained willing to give the United Nations another opportunity to act while additional American and British forces were deployed to the Middle East. Troop deployments accelerated throughout the fall of 2002, with the goal of making an invasion possible after the first of the year during the cooler winter months. Renewed inspections by the United Nations Monitoring, Verification, and Inspection Commission (UNMOVIC) yielded mixed evidence of Iraqi cooperation between November 2002 and January 2003. The inspectors' January 2003 report noted that access to previously restricted sites and interviews with some Iraqi scientists had been granted, but that incidents of obstruction and harassment indicated that the Iraqi government "appears not to have come to a genuine acceptance, not even today, of the disarmament which was demanded of it." 117 The Security Council was divided among leaders that felt the inspections should be given more time, and those that contended that the inspections had once again failed. U.S. Secretary of State Colin Powell summarized the intelligence supporting allegations of Iraq's links to terrorist groups and possession of WMD in a briefing to the UN General Assembly, only to have the French Foreign Minister dispute much of his evidence. The United States, Great Britain and Spain

\footnotetext{
${ }^{116}$ Anne Applebaum, "Old Europe vs. New Europe," in Beyond Paradise and Power: Europe, America and the Future of a Troubled Partnership, ed. Tod Linberg (New York: Routledge, 2005), 36.

${ }^{117}$ United Nations Documentation Center, “An Update on Inspection: Report of the Executive Chairman of UNMOVIC to the United Nations Security Council, January 27, 2003," http://www.un.org/ Depts/unmovic/ recent\%20items.html.
} 
jointly introduced another resolution authorizing military action against Iraq while France and Germany prepared an alternative resolution calling for a strengthened weapons inspection regime. Both resolutions were withdrawn in early March after French leaders made it clear that they, along with Russia, would veto any Security Council resolution authorizing the immediate use of force against Iraq. This deadlock meant that any support to the American-led effort to remove Saddam Hussein from power would have to be provided on a bilateral basis, without the benefit of a mandate from either NATO or the UN.

\section{NATO Support for Operation Iraqi Freedom (OIF)}

In the first few days of the war, President George W. Bush noted that "the coalition that we've assembled today is larger than one assembled in 1991 in terms of the number of nations participating. I'm very pleased with the size of our coalition."118 While the coalition assembled for OIF did indeed consist of a greater number of states than those assembled for either Desert Storm or OEF, only a few of these states demonstrated a willingness or capability to contribute to combat operations in Iraq. ${ }^{119}$ Of these, Great Britain made the most extensive contribution to the military campaign. Prime Minister Tony Blair overcame considerable parliamentary and public opposition to give his country a leading role alongside the United States in both the military and

\footnotetext{
${ }^{118}$ White House Office of Press Secretary, "President Bush, Prime Minister Blair Hold Press Availability, March 27, 2003," http://www.whitehouse.gov/news/releases/2003/03/20030327-3.html.

${ }^{119}$ The declared coalition of 44 countries supporting military action in Iraq included: Afghanistan, Angola, Albania, Australia, Azerbaijan, Bulgaria, Colombia, Czech Republic, Denmark, Dominican Republic, El Salvador, Eritrea, Estonia, Ethiopia, Georgia, Great Britain, Honduras, Hungary, Iceland, Italy, Japan, Kuwait, Latvia, Lithuania, Macedonia, Marshall Islands, Micronesia, Mongolia, Netherlands, Nicaragua, Philippines, Poland, Portugal, Romania, Rwanda, Singapore, Slovakia, Solomon Islands, South Korea, Spain, United States and Uzbekistan.
} 
diplomatic battles waged over Iraq. Great Britain contributed an armored division along an Amphibious Task Group consisting of 33 ships. British deployments far exceeded that of any other ally, eventually reaching 46,000 troops, and equating to nearly one quarter of British land forces and one third of British air forces. ${ }^{120}$ These were among the only forces to serve in combat roles alongside America troops during the invasion of Iraq.

Both military and diplomatic support was provided by a number of traditionally Atlanticist states, including many of the Alliance's newest members. Denmark contributed a medical unit along with two warships and a submarine to monitor Iraqi intelligence activities. Spain similarly deployed three naval vessels in support of OIF. Spain, Italy, and Portugal all allowed the United States military to use their airbases and seaports. Bulgaria, Hungary and Romania offered the use of their bases and airspace along with small numbers of support troops. The Czech Republic and Slovakia contributed antibiological and antichemical warfare units, although these units remained based in Kuwait throughout the duration of the war. ${ }^{121}$

The newest members of NATO offered support despite suggestions by some other European leaders that overt support for the war might endanger their efforts to gain entry into the EU. During a February EU Summit, the European Parliament's Foreign Affairs Committee chairman, Elmar Brok, reminded candidate countries that the Maastricht Treaty required all members to support "without reservation the EU's foreign policy positions" and that support for U.S. policy in Iraq "might ultimately endanger those

\footnotetext{
${ }^{120}$ These numbers represent approximately one quarter of the British land forces and one third of British air forces. John Keegan, The Iraq War (New York: Alfred A. Knopf: 2004), 100.

${ }^{121}$ Condoleezza Rice, “Our Coalition,” Wall Street Journal, March 26, 2003.
} 
candidates' accession." ${ }^{22}$ Despite these and other warnings, the Polish government continued to express support for the United States and joined the British in sending special operations forces to participate in the combat phases of OIF. Other NATO governments were less interested in upsetting domestic and international contingents and rebuffed the American requests for support.

Turkey's refusal to contribute forces or even to allow the United States to launch attacks into Iraq from Turkish soil came as a surprise to many American officials. The Islamist Justice and Development Party gained power during parliamentary elections in November 2002, making negotiations more difficult for American diplomats and military planners hoping to establish a northern front in the event of a war with Iraq. The Turkish government resisted American pressure to allow United States military forces to launch an attack against Iraq from its territory. Numerous enticements, including the offer of $\$ 6$ billion in foreign aid, were insufficient to gain the approval of the Turkish parliament. ${ }^{123}$ Turkish desires to support the United States in its attempt to remove Saddam Hussein from power were balanced by public opposition to initiating a war against a fellow Muslim state and concerns that any assistance to Kurdish forces in Iraq could encourage Kurdish separatists in Turkey to rekindle their attempts to acquire greater autonomy. Turkey's rejection of basing and transit rights caused considerable difficulties for American military planners. Although many states in the region agreed to quietly lend support to the American-led coalition, there were few other governments willing to serve

\footnotetext{
${ }^{122}$ Radio Free Europe/Radio Liberty News Line, "European Officials Suggest Stances on Iraq Might Affect Accession, February 10, 2003," http://www.rferl.org/newsline/2003/02/l00203.asp.

${ }^{123}$ Keegan, The Iraq War, 138.
} 
as basing sites. Saudi leaders declined to give the United States and its coalition partners access to the command facilities used during the 1991 Gulf War. Strained relations with Iran and Syria made the stationing of American troops on their soil out of the question despite their history of conflict with the Iraq. Jordan had a history of greater cooperation with the United Sates, but its government did not wish to allow coalition forces to operate from their territory for fear of a public backlash. As a result, troops based in Qatar, Oman, Bahrain, Kuwait would serve as the central invasion force. Military planners were forced to revert to a secondary strategy of equipping some 50,000 Kurdish fighters in northern Iraq so that they could fight alongside coalition special operations forces. The Turkish government eventually conceded to support this strategy by restoring overflight rights for American aircraft and granting permission for the transport of military supplies through Turkey.

The Iraq War began on March 19, 2003 with an American attempt to "decapitate" the Iraqi leadership by launching an airstrike on a location just outside of Baghdad where Saddam Hussein was reported to be meeting with top Iraqi officials. American and British ground forces entered Iraq from Kuwait the following day, frustrating Iraqi expectations that a massive air offensive would precede any land campaign. American commanders arguing against a repeat of the 1991 Desert Storm air campaign pointed out that an extended period of bombing would provide Iraqi leaders with "both opportunity and cause to use weapons of mass destruction against them."124 While Turkey's unwillingness to allow coalition forces to enter Iraq from the north caused a revision to

${ }^{124}$ Ibid, 142. 
existing invasion plans, it also presented an opportunity for further deception. Instead of having the forces intended for a northern attack join those already in the Persian Gulf, coalition commanders kept them in the eastern Mediterranean in order to create the impression that they were still weeks away from initiating a ground offensive. This deception contributed to the element of surprise associated with the launching of an immediate ground offensive.

Rather than relying on airpower to disrupt Iraqi command and control prior to initiating the invasion, coalition commanders relied on the speed of their ground offensive to disrupt Iraqi defensive preparations and complicate their efforts to organize their forces for a counterattack. A rapid offensive was expected to build momentum that would demoralize Iraqi troops and encourage mass surrenders or desertions. Coalition forces advanced as rapidly as possible, bypassing Iraqi strongholds in order to secure Iraq's southern oil fields and many of its population centers in the first few days of the war. Pitched battles were fought to gain control of Najaf, Samawah, and Hillah, but with very light losses among coalition forces. These troops entered Baghdad during the first week of April and then moved on to secure Tikrit, Saddam's birthplace and the last major population center outside coalition control. On May 1, 2003 President Bush declared an end to major combat operations in Iraq, once again emphasizing the significance of Saddam's defeat to the GWOT. Bush stated, "We've removed an ally of Al Qaeda, and cut off a source of terrorist funding. And this much is certain: No terrorist network will 
gain weapons of mass destruction from the Iraqi regime, because the regime is no more." 125

\section{NATO's Role in Stabilization and Reconstruction Efforts in Iraq}

The collapse of the Iraqi government created a security vacuum in Iraq that coalition forces were immediately called upon to fill. As Iraqi military and police forces deserted their posts following the fall of Baghdad, a period of lawlessness ensued marked by widespread looting and violence. Coalition forces shifted to a security posture in order to reestablish order until domestic forces could be reconstituted and equipped to fulfill this task. Long-standing conflicts between the ethnic Kurd, Shia and Sunni populations of Iraq had to be carefully managed to prevent the country from further collapsing into chaos or even civil war. While American leaders envisioned a peaceful, democratic Iraq as becoming a beacon of hope for the region, the immediate post-war situation threatened to make Iraq a source of violence and unrest that could have negative implications for Iraq's neighbors.

Continued division within the UN and NATO meant that combat forces from the United States, Great Britain, and Poland would have to transition into a peacekeeping role with little outside assistance. Unable to find a regional ally willing to accept leadnation responsibility for the post-war peacekeeping effort as had been done in Afghanistan, the United States maintained overall responsibility for post-war stabilization efforts, with Great Britain and Poland each assuming control of small portions of the country. Jay Garner, head of the U.S. Department of Defense's Office of Reconstruction

\footnotetext{
${ }^{125}$ White House Office of Press Secretary, "President Bush Announces Major Combat Operations in Iraq Have Ended, May 1, 2003" http://www.whitehouse.gov/news/releases/2003/05/iraq/20030501-15.html
} 
and Humanitarian Assistance, initially took charge of the Coalition Provisional Authority (CPA) charged to guide the administration of government responsibilities in advance of a new Iraqi government. British commanders established control over portions of southern Iraq, pledging to maintain a division indefinitely for this purpose. The smaller Polish contingent was less capable of independent operations, and soon requested administrative support from NATO headquarters to carry out its responsibilities within its sector. An agreement was established in June 2003, allowing NATO military authorities to conduct a variety of supporting roles, including force generation, communication, and logistics planning within the Polish sector. This support was crucial to the creation of a Polishled multinational division in south-central Iraq, with troop contributions coming from several NATO states.

A massive commitment of resources was necessary to provide the new Iraqi government with the necessary assistance to ensure adequate security and economic revitalization of the Iraqi economy. The costs of Iraqi reconstruction were expected to exceed those of the war itself, and were greatly underestimated by the Bush administration and many of its supporters. Many hoped that reconstruction could be financed primarily out of profits acquired by restoring Iraqi oil production. Pollack's estimate of Iraqi reconstruction costs was typical of many pre-war assessments. Using historical figures of between $\$ 75-\$ 300$ in international aid per person in post-war states ranging from 1950s Korea to 1990s Bosnia-Herzegovina, Pollack calculated an annual reconstruction cost of $\$ 7$ billion. He estimated that at least $\$ 1$ billion of this cost could be offset by oil profits, with the rest shared by the United States and the international 
community. This rationale brought the anticipated cost of Iraq's reconstruction to the United States to $\$ 5$ billion over three years. ${ }^{126}$

The relatively low estimates on the cost of Iraqi reconstruction were based on optimistic assumptions that the United States and its allies would able to decapitate the Iraqi government while keeping the country's infrastructure intact. The estimated cost of Iraq's reconstruction grew rapidly following assessments by the CPA, the United Nations and the World Bank. These assessments found that the deterioration of Iraq's infrastructure since the outbreak of the 1980 Iran-Iraq War was much greater than previously known. The effects of more than ten years of sanctions, compounded by the damage inflicted by coalition forces and post-war looting helped raise the estimates of reconstruction to between $\$ 50-\$ 100$ billion. ${ }^{127}$ These estimates did not include the cost of maintaining large numbers of coalition forces in the region. Even with these forces in place, additional security measures had to be taken, adding $50-80 \%$ to the cost of many reconstruction projects. ${ }^{128}$ While Iraq's vast petroleum reserves made it likely that the Iraqi economy would eventually be revived, it would take a long period of time to reach pre-Gulf War oil production levels. Issam Al-Chalabi, Iraq's oil minister in Iraq in the late 1980s, estimated that it would still take several years to reach equivalent levels of 3.5 million barrels a day and perhaps as many as ten years before peak production of 5.5

\footnotetext{
${ }^{126}$ Kenneth Pollack, The Threatening Storm: The United States and Iraq: The Crisis, the Strategy, and the Prospects After Saddam (New York: Random House, 2002), 471.

${ }^{127}$ U.S. Congressional Budget Office, Paying for Iraq's Reconstruction, (Washington D.C.: CBO, 2004).

${ }^{128}$ Griff White, "Reconstruction Costs Unkown," The Washington Post, May 10, 2005.
} 
million barrels a day could be achieved. ${ }^{129}$ In the meantime, international aid would be required to help the Iraqi manage the process of rebuilding the country's physical, economic, and financial infrastructure.

An October 2003 donors' conference in Madrid yielded promises of $\$ 13$ billion in foreign aid to Iraq on top of pledges of approximately $\$ 20$ billion in aid from the United States. Other NATO governments accounted for only a small portion of these pledges. The combined pledges of European contributors and the EU totaled just over $€ 1.25$ billion. ${ }^{130}$ The majority of aid from Europe was pledged by states that had publicly supported the United States prior to the outbreak of war. British and Spanish contributions alone made up the majority of European contributions, while both France and Germany refused to agree to provide any new aid to Iraq. ${ }^{131}$ A second conference held in Tokyo one year later yielded no new aid pledges, only a general agreement on the need to accelerate the delivery of aid to Iraq in accordance with existing commitments.

The persisting high level of violence within Iraq contributed to the unwillingness of international organizations to offer meaningful assistance. The UN established a headquarters in Baghdad following the passage of UNSCR 1186 in May 2003, which lifted economic sanctions and began the process of reintegrating Iraq back into the international community. The United Nations Assistance Mission in Iraq (UNAMI) was

\footnotetext{
${ }^{129}$ Alison Smale, "Iraq May Be Years From Returning To Peak Oil Output, Ex-Minister Says," International Herald Tribune, September 22, 2005.

${ }^{130}$ European Union Office of External Relations, "The EU's Relations with Iraq," http://europa.eu.int/ comm/external_relations/iraq/intro/.

${ }^{131}$ Public Broadcasting System, “Iraq Aid, October 24, 2003,” http://www.pbs.org/newshour/ bb/middle_east/july-dec03/iraq_10-24.html
} 
formed to provide assistance in the conduct of elections, the restoration of essential social services, and the drafting of an Iraqi constitution. These efforts were greatly curtailed after the building occupied by the United Nations mission was struck by a suicide bomber in August 2003. This attack killed more than twenty UN personnel, including the UN Special Representative to Iraq, and contributed to the international community's hesitation to become more deeply engaged in Iraq. Nearly a year would pass before the United Nations Security Council agreed to sanction a multinational peacekeeping force for Iraq. In June 2004, the transfer of sovereignty from the CPA to the Iraqi Governing Council prompted a greater outpouring of international support. UNSCR 1546 responded to a request of the Iraqi government by calling on all states and international organizations "to contribute assistance to the multinational force, including military forces, as agreed with the Government of Iraq."132 Despite a general increase in international support for stabilization efforts in Iraq, division within NATO continued to limit the role of the Alliance would play in this process.

Twenty countries initially pledged troops for a UN-backed Iraq Stabilization Force (SFIR) to serve under the direction of American commanders and augment the coalition forces already in Iraq. The size of the international coalition peaked to 38 states providing 50,000 troops to assist the more than 120,000 American forces maintained in Iraq. Many NATO states agreed to introduce forces or expand their presence in Iraq following the passage of UNSCR 1546, including Bulgaria, the Czech Republic, Denmark, Hungary, Lithuania, Poland, the Netherlands, Romania, and Turkey. Germany

\footnotetext{
${ }^{132}$ United Nations Documentation Center, "United Nations Security Council Resolution 1546, June 8, 2004,” http://daccessdds.un.org/doc/UNDOC/GEN/N04/381/16/PDF/N04381 16.pdf?OpenElement
} 
and France remained conspicuously absent from the SFIR, but softened their opposition to deploying a small NATO contingent to Iraq to conduct training for Iraqi military personnel. Up to this point NATO headquarters had been performing training and support functions outside of the country, which primarily consisted of coordinating the attendance of several dozen Iraqi officers to various NATO service schools.

During the June 2004 Summit in Turkey, the NAC addressed a request from Iraqi Prime Minister Ilyad Allawi to provide the Iraqi military with greater training assistance and equipment. NATO governments agreed to increase shipments of military equipment to Iraq, particularly Russian-built equipment from Central and Eastern Europe that would be compatible with that operated by the Iraqi military. The Alliance established the NATO Training and Equipment Coordination Group (NTECG) to solicit donations of equipment. In a little more than a year, over $€ 100$ million worth of equipment was donated to the Iraqi Armed Forces by NATO member states. The largest donation came from Hungary, which donated 77 tanks and four tank-recovery vehicles to the Iraqi Armed Forces. Romania and Slovenia also made substantial donations that totaled more than $23,000 \mathrm{AK}-47$ rifles, 10,000 helmets and various types of other equipment. ${ }^{133}$

A NATO Training Implementation Mission was established in Iraq with a staff of 50 people to begin providing training to the Iraqi military and make preparations for a more substantial NATO presence inside Iraq. Following Iraqi elections in January 2005, NATO General Secretary De Hoop Scheffer announced, "Iraq now has a democraticallyelected parliament and government that wants to work with all friends of Iraq to bring

\footnotetext{
${ }^{133}$ NATO Office of Information and Press, "NATO Nations have donated $€ 100$ million worth of equipment to the Iraqi Armed Forces, December 15, 2005," http://www.afsouth.nato.int/JFCN_Missions/ NTM-I/Articles/NTMI_A_14_05.htm.
} 
peace and stability. In this new phase, there is no reason for any country not to make a significant contribution to this effort, and compelling reasons why all of us should do so." ${ }^{134}$ The allies agreed to fully fund the NATO training mission in Iraq and increase its staff up to 360 personnel. The NAC announced a goal of increasing its annual training capacity to 1,000 Iraqi officers inside Iraq and 500 outside of Iraq each year. This would be accomplished through the creation of a NATO Training and Education Doctrine Center (TEDC) and increased Iraqi enrollment in NATO training facilities in Germany, Italy and Norway. All 26 NATO member states agreed to contribute in one form or another to the Iraqi Training Mission, although some contributions fail to reflect the full capacity of NATO military forces. ${ }^{135}$

\section{Contrasting Stabilization and Reconstruction Efforts}

NATO's command of ISAF in the fall of 2003 boosted the confidence of Afghan leaders in the international community's commitment to Afghan security and led to further improvements in the security situation within Afghanistan. ISAF forces succeeded in training the first units of the new Afghan National Army and by November 2003, the relative calm in Kabul led Afghani officials to lift the nightly curfew that had been in place for 23 years. ${ }^{136}$ NATO's leadership of ISAF also reinvigorated an ongoing debate over extending ISAF operations beyond the boundaries of Kabul. President Karzai had lobbied for an extension of the ISAF mandate and he was soon joined by

\footnotetext{
${ }^{134}$ NATO Office of Information and Press, "NATO Update: NATO committed to Iraq, says Secretary General, June 23, 2005," http://www.nato.int/docu/update/2005/06-june/e0623a.htm.

${ }^{135}$ For example, French leaders have failed to embrace the NATO training effort and sent only one officer to Iraq to serve in the TEDC.

136 “ISAF, Under the Leadership of Turkey," CENTCOM Coalition Bulletin, no. 3 (January 2003): 9.
} 
other regional leaders. Despite the wariness of some European governments, an international consensus was eventually reached that would give ISAF a larger role in Afghanistan.

The UN Security Council unanimously passed UNSCR 1510 on October 13, 2003, expanding the ISAF mission beyond Kabul. ${ }^{137}$ NATO officials agreed to expand their presence in Afghanistan to other population centers, but resisted any proposals calling for a large increase in the size of the ISAF contingent. Any increase in the number of troops committed to ISAF would place greater strains on the limited number of forces and equipment already participating in the Alliance's other peacekeeping missions. A compromise solution was found by adopting an approach pioneered by OEF coalition forces continuing to pursue Taliban and $\mathrm{Al}$ Qaeda figures in the region. ISAF operations outside of Kabul would be conducted through the formation of Provincial Reconstruction Teams (PRTs). PRTs had been utilized by OEF coalition commanders since December 2002 as a means of extending their influence in remote areas and the facilitating relations between military commanders, local authorities and representatives of non-governmental organizations. Coalition commanders and Afghan government officials shared an appreciation for the effectiveness of PRTs. The Afghan Minister of Foreign Affairs, Dr. Abdullah Abdullah, observed "PRTs are considered extremely

\footnotetext{
137 United Nations Documentation Center, "United Nations Security Council Resolution 1510, October 13, 2003," http://daccessdds.un.org/doc/UNDOC/GEN/N03/555/55/PDF/N0355555.pdf?OpenElement.
} 
successful by the people, are supported by the central government ... [and] their impact on reconstruction, development and peace will benefit all."138

Through the organization of several PRTs, ISAF forces began extending their presence outside of Kabul in early 2004. These PRTs were typically made up of a group ranging from several dozen to several hundred military and civilian personnel organized to conduct patrols and perform reconstruction projects or provide security for others involved in humanitarian relief. The first NATO-led PRT was sent to Kunduz in January 2004. NATO leaders announced their intention to assume responsibility for four more PRTs in Mazar-e-Sharif, Maimana, Feyzabad and Baghlan at the Alliance's Istanbul summit in June 2004. ISAF would establish a logistics support base near Mazar-e-Sharif in order to have both logistical support and additional security personnel available to PRTs operating in northern Afghanistan. ${ }^{139}$ The increased reach of ISAF enabled new reconstruction efforts to get underway and complemented voter registration efforts in preparation for national elections in the fall of 2004. NATO temporarily increased its force levels to more than 10,000 troops around the time of the 2004 elections in Afghanistan. Both Spain and Italy deployed additional battalions to assist the Afghan National Army (ANA) and Afghan police with security in selected regions throughout the country. The willingness of the allies to deploy more troops in the face of increasing violence demonstrated the depth of NATO's commitment to Afghanistan's future. As one

\footnotetext{
${ }^{138}$ Frederic Greenwood, "PRTs: Military Personnel Provide Unique Reconstruction Capabilities," CENTCOM Bulletin no. 5 (May 2003): 6.

${ }^{139}$ NATO Office of Information and Press, "NATO Factsheet: NATO in Afghanistan, February 12, 2005," http://www.nato.int/issues/afghanistan/040628-factsheet.htm.
} 
NATO official observed at the time, "Afghanistan is where NATO's credibility is on the line." 140

NATO forces were temporarily increased once again prior to parliamentary elections in September 2005. Increasing attacks on election workers and both civilian and religious leaders were viewed as an attempt by groups hostile to the Afghan government to disrupt the election process. NATO member states agreed to deploy an additional 2,000 troops from the Netherlands, Romania, Italy, Austria and the United States, bringing ISAF up to its highest troop levels to date, with some 11,400 soldiers in Afghanistan. Taliban insurgents failed to disrupt the September 2005 parliamentary elections in Afghanistan or organize an effective boycott. Election-day violence was very limited, with no bombings or suicide attacks.

The peaceful conduct of Afghan legislative elections served as an opportunity for NATO member states to once again reexamine their role in Afghanistan. ISAF expanded into Western Afghanistan in 2005, with the goal of establishing a security presence in $50 \%$ of Afghanistan's territory by the end of the year. During a September 2005 conference of NATO Defense Ministers in Berlin, U.S. Secretary of Defense Rumsfeld formally proposed merging OEF and ISAF operations under a single NATO commander. Officials from Germany, France, and Spain initially opposed any restructuring of the ISAF mission that would require troops under NATO command to become more involved in counterinsurgency operations. German Defense Minister Struck claimed that merging the two missions would fundamentally change NATO's role in Afghanistan and

\footnotetext{
${ }^{140}$ Paul Richter, “NATO Balking At Iraq Mission,” Los Angeles Times, May 9, 2004.
} 
"would make the situation for our soldiers doubly dangerous and worsen the current climate in Afghanistan...NATO is not equipped for counter-terrorism operations. That is not what it is supposed to do." ${ }^{41}$ A French Defense Ministry official, similarly observed, "The two missions were completely different. If you suddenly merge special forces or heavy counter-terrorism units with stabilizing forces, which is NATO's role in Afghanistan, then you completely undermine NATO's role." ${ }^{142}$ A senior NATO official characterized this opposition as "pacifism" among a number of member states. In his experience, "Countries like Germany and Spain are just not prepared to put their soldiers in a position where they might get killed. They are happy to sign up for peacekeeping operations, but they are not prepared to deploy their troops on the front line."143

A compromise solution was proposed by General Jones, SACEUR, wherein NATO would oversee dual chains of command, one responsible for counterinsurgency operations and the other for more traditional peacekeeping roles. ${ }^{144}$ Participating states could contribute troops to one or both operations in order to enable both missions to continue without forcing individual governments to commit their forces to tasks they might not be prepared to accept. An increased number of troops from Canada, Great Britain, and the Netherlands would make up the bulk of the additional forces need to

${ }^{141}$ Judy Dempsey and David Cloud, "Europeans Balking At New Afghan Role," International Herald Tribune, September 14, 2005.

142 Ibid.

${ }^{143}$ Tom Coughlin, "NATO 'Pacifists' Under Fire As U.S. Begs Help On Terror Front Line," London Sunday Telegraph, September 18, 2005.

${ }^{144}$ Daniel Dombey and Peter Spiegel, "Concerns In NATO As Troops Prepare For Afghan Mission," London Financial Times, September 12, 2005. 
expand NATO's presence in southern Afghanistan. NATO's expansion into the south of Afghanistan will cover an additional six provinces, and the establishment of at least four new Provincial Reconstruction Teams. The addition of 5,000 NATO troops will be accompanied by an equivalent reduction in American forces. British troops are expected to play a lead role in the region, running a headquarters in Kandahar and overseeing forces from Canada, the Netherlands, and the United States operating in four southern provinces. German troops will lead NATO forces in the north and Italian troops will oversee operations in western Afghanistan.

Combining the OEF coalition and NATO missions into a single operation marks another crossroads for the Alliance that has the potential to either ease or exacerbate transatlantic tensions. The outcome of this proposed merger of ongoing operations in Afghanistan will depend primarily on the willingness of American leaders to reassert their commitment to multilateralism. A perception that this proposal is simply a means to provide short-term relief to overstretched American forces at the expense of its NATO allies will lead to greater cynicism within many European governments. However, a reorganization that maintains a strong American presence in the region while unifying the chain of command for both counter-terrorism and peacekeeping operations has the potential to reinvigorate the Alliance by giving it a larger role in the GWOT. A single NATO-led security assistance mission with significant participation by the United States can provide an opportunity to demonstrate the contemporary relevance of NATO, but only if American leaders avoid the domineering behavior that has characterized much of the GWOT. 
NATO's high profile in Afghanistan stands in stark contrast to its role in Iraq. While the overall scope of the stabilization and reconstruction effort is much larger in Iraq, NATO's training contingent is quite small. Individual NATO member states continue to deploy troops to Iraq under the UN-mandate originating from UNSCR 1586 and through bilateral agreements with the United States, but the Alliance's internal bodies and shared resources have not been fully utilized.

NATO's training assistance has nonetheless helped the Iraqi government make progress towards its goal of fielding a 10-division army along with adequate internal security forces by the end of 2006 . The number of Iraqi military and security forces only recently began to outnumber the coalition forces in Iraq. According to U.S. Defense Department estimates, Iraqi forces had grown from fewer than 100,000 in July 2004 to more than 210,000 in November $2005 .{ }^{145}$ This number greatly exceeded the 160,000 foreign troops deployed in advance of the 2005 Iraqi parliamentary elections. Some 26 countries, including 12 NATO states continue to maintain around 23,000 troops in Iraq. NATO contributions range from Great Britain's 12,000-strong contingent to the handful of Dutch and French officers participating in the NATO training force. According to U.S. Secretary of Defense Donald Rumsfeld, the scope of activities undertaken by coalition forces have shifted "from conducting security operations essentially to a heavier focus on training, equipping and assisting the Iraqi forces." 146

\footnotetext{
${ }^{145}$ Rowan Scarborough, "Rumsfeld Rejects 'Quitting' As 'Exit Strategy' From Iraq” Washington Times, November 20, 2005.

${ }^{146}$ Donald Rumsfeld, "We Must Be Patient About Progress In Iraq” Seattle Times, July 4, 2005.
} 
Plans are underway to reduce the number of foreign military forces serving in Iraq as the country's military and security forces become more capable and the political process moves forward. The completion of milestones marking a national referendum approving a new Iraqi constitution and the peaceful staging of parliamentary elections allow for a reassessment of coalition troops levels. American leaders began troop reductions in early 2006 , with the intention of withdrawing as many as 100,000 troops by the end of the year. Most of the other states participating in the coalition have announced that they will also withdraw most, if not all, of their troops during this period. ${ }^{147}$ The remaining troops will serve in an advisory role to Iraqi forces capable of defending their population against internal and external threats. The opportunity will exist for NATO to enlarge its presence in Iraq as part of the realignment of coalition forces, if the allies are so inclined.

Any realignment of forces must account for the political developments in Iraq along with the capability of the Iraqi security and military forces. Even many of the United States' past critics are advising against a rapid reduction of foreign forces. French Prime Minister Dominique de Villepin recently acknowledged that a rapid withdrawal would lead to unwanted chaos in Iraq and he cautioned fellow European leaders that any withdrawal "should be coordinated with the local situation in Iraq and the regional situation." ${ }^{148}$ The newly elected German Chancellor, Angela Merkel, is also seeking to improve relations with U.S. and avoid any further conflict over the role of coalition

\footnotetext{
147 "U.S.-led Coalition Shrinks as More Nations Pull Troops," Los Angeles Times, December 28, 2005.

148 "French Dove Turns Hawk on Pullout," New York Post, November 30, 2005.
} 
forces in Iraq. During her first visit to the United States as Chancellor in January 2006, she observed, "Good transatlantic relations between not only the Federal Republic of Germany and the United States of America, but also between the European Union and the United States... are in the vested interest of both sides." that NATO "should remain as the center of political discussion on the implications of [international] crises and the permanent analysis of the various threats." ${ }^{150}$ While NATO member states have succeeded in overcoming much of the bitterness that characterized the debate over the necessity for invading Iraq, the situation to date still stands as an example of inadequate consultations and missed opportunities for collective action. Regime Analysis: NATO's Role in the Global War on Terrorism

This chapter has examined the various ways that NATO contributed to global efforts to counter the threats posed by international terrorism and the proliferation of WMD. The unprecedented destruction resulting from the terrorist attacks on the United States in September 2001, combined with the aspirations of Al Qaeda leaders to conduct even more horrendous attacks, evoked a new willingness to confront these threats on the part of NATO governments. Al Qaeda was deemed to be a threat to the security of the United States and its allies, as was the Taliban government in its role as collaborator and protector of terrorist leaders. The boldness of these attacks led member governments to invoke the collective defense clause of the North Atlantic Treaty for the first time in the history of the Alliance. This decision demonstrated the shared resolve of NATO member

\footnotetext{
${ }^{149}$ German Marshall Fund of the United States, "German Chancellor Stresses Importance of Relationship with United States," http://www.gmfus.org/press/article.cfm?id=58.

${ }^{150}$ Andrew Borowiec, "Funding Shortage Threatens EU Force," Washington Times, February 16, 2006.
} 
governments and made Alliance assets available for military operations in Afghanistan. NATO member states made numerous military and non-military contributions to operations in Afghanistan, culminating in the NAC's agreement to assume command of ISAF in the fall of 2003. Enlarging the GWOT to include the removal of Saddam Hussein's government in Iraq was much more controversial and led to a breakdown in consensus among NATO member states. Division within the Alliance between states aligning themselves with the United States and those opposed to the use of force to coerce Iraqi disarmament prevented NATO from facilitating collective action. Just as during the previous two periods of study, the behavior of member states toward the practice of collective defense and collective security can be attributed to various factors associated with the three dominant approaches to regime analysis.

The United States' status as the sole global superpower and the its preponderance of military power relative to its NATO allies strongly influenced the organization of forces for military operations in Afghanistan and Iraq, as is commonly emphasized in a power-based approach to regime analysis. The United States' status as the dominant international power gave American leaders a global perspective, while European leaders generally remained focused on events in Europe. American military, diplomatic, and commercial entities maintained a higher profile in most regions of the world than their European counterparts. While this global presence gave the United States an opportunity to influence many security issues, it also increased the likelihood that the United States would be the target of international terrorist groups. The GWOT resulted from an attack on the United States, and American leaders actively shaped the collective response. Allied participation was encouraged by the United States, expressed through the 
invocation of Article Five and solicitations for both military and non-military assistance. The conduct of both OEF and OIF reflected the preferences of American war planners, who operated from an assumption that while the contributions of NATO allies were desirable, allied participation should not be pursued under conditions that would unduly constrain the United States.

A NATO-led CJTF was one option for the organization of multinational coalitions to conduct the GWOT. Due to concerns over the need for a timely response and an unwillingness to accept additional constraints on their use of force, American leaders elected to conduct OEF as a coalition operation under the direction of U.S. Central Command. As U.S. Secretary of Defense Donald Rumsfeld explained, "Every nation is different, with different cultures and geographies, and the thought that they should all agree at the same moment how to contribute to this war is nonsense. That will never happen, and it never has. Countries ought to decide individually what they can do. That's not a blow to NATO."151 Rather than exercising leadership to further encourage the practice of collective security within the Alliance, the United States took the more expedient route of forming an ad-hoc coalition for both OEF and OIF.

Alliance officials hoping to see NATO pursue a wider role in international affairs could not help viewing the American approach to coalition building as a setback to NATO's further embrace of a collective security regime. General Klaus Naumann, former Chairman of NATO's Military Committee, noted "While individual allies are contributing to the U.S.-led operations in Afghanistan, NATO has been unable to offer

\footnotetext{
151 James Kitfield, “U.S. to NATO: Change or Else," National Journal 2, (October 2002): 2978-9.
} 
much more than political support. Nor has the U.S. Administration asked for much more, implying that they do not need, or do not wish to use, NATO." 152 The American decision to opt for an ad-hoc coalition resulted in lingering resentment in some quarters of Europe. In the months following OEF, one observer noted "The phrase used in Europe - only partly tongue-in-cheek - is that the United States is not looking for coalitions of the willing and able but of the willing and compliant." ${ }^{\text {"153 }}$ EU High Representative Solana strongly criticized the American approach to OEF, defending the principle that "the alliance should determine the coalition and not vice versa." 154 Solana also remarked, "I don't like this principle that the 'mission defines the coalition'. NATO invoked its most sacred covenant that no one had dared touch in the past, and it was useless! Absolutely useless! At no point has General Tommy Franks even talked to anyone at NATO."155 Collective security was not practiced during OEF primarily due to the absence of support from the United States, whose leaders were unwilling to compromise on the timing and scope of offensive military operations.

As the need for post-conflict stabilization and reconstruction efforts operations became apparent, the United States was more receptive to NATO leadership and American leaders succeeded in convincing other NATO member states to assume lead nation responsibility for the ISAF mission. President Bush and other senior American

\footnotetext{
${ }^{152}$ Naumann, "Crunch Time for the Alliance," 9.

${ }^{153}$ Steven Everts and Gary Schmidt, "Is Military Power Still the Key to International Security?" NATO Review 50, no. 4 (Winter 2002): 17.

${ }^{154}$ James Kitfield, "Pox Americana?," National Journal 34, (April 6, 2002): 986.

${ }^{155}$ Ibid, 984.
} 
officials expressed a desire to limit the role of the United States military forces in peacekeeping operations. NATO's eventual leadership of ISAF was consistent with the interests of the United States in that it supported ongoing counter-terrorism operations without requiring the participation of more than a few American troops. NATO's command of ISAF furthered the American reliance on European forces as peacekeepers, as had increasingly become the case in the Balkans. This marked the continuation of a division of labor that would later be colorfully described as the Americans "making the dinner" and Europeans "doing the dishes." 156 While the division of responsibilities between OEF and ISAF satisfied the immediate desires of the United States, it would become a source of tension with implications for future collective efforts.

The disinclination of American leaders to encourage the further empowerment of international organizations was even more evident in the run-up to the Iraq War. One set of analysts claims the lesson learned by American leaders in OEF to be that "Europeans will whine and complain about any military operation, but victory will obviate such complaints and the Europeans will jump on the bandwagon. The process through which the coalition was created would not matter in the end. Because preeminent U.S. military power alone could produce a victory, there was little reason to endure the trials and tribulations of multilateral negotiations. In the end, all that is necessary to achieve support is to be clear, to be consistent, and to be America." 157 These leaders once again

\footnotetext{
${ }^{156}$ European Union Office of External Relations, "Speech by the Honorable Dimitris Platis at Columbia University, May 15, 2003," http://europa-eu-un.org/articles/hu/article_2375_hu.htm.

${ }^{157}$ Gordon and Shapiro, Allies at War, 65.
} 
sought allied assistance in their upcoming confrontation with Iraq, but did not wish to accept unnecessary constrains on their freedom of action.

American leaders sought to take advantage of opportunities created by favorable balance of power. In their view, the combination of military and moral superiority entitled the United States to take the actions necessary to achieve a more peaceful international order without placing a great deal of emphasis on the desires of other governments. Luck points out that "Given its singular power, the United States has been more prone than most countries to question the legitimacy and fairness of institutions whose rules and procedures do not take into account the distribution of power in the real world outside." ${ }^{158}$ Keegan similarly observes a sense of "particularism" among American leaders during this period that he characterizes as a belief in the "superior principles of public and interstate behavior" embodied by the United States. ${ }^{159}$ The neoconservative views of many in the Bush administration argued that the United States' status as the preeminent global power granted them exceptional rights and privileges. Rather than seeking to develop an international response to the threat posed by Iraq through substantive exchanges and collective decision-making, the United States preferred to choose a course of action and then solicit international support.

American leaders publicly challenged the need for the United States to adhere to the practice of obtaining an international consensus as part of a collective security regime. U.S. Secretary of State Colin Powell remarked on the administration's limited

\footnotetext{
${ }^{158}$ Edward Luck, "The United States, International Organizations and the Quest for Legitimacy," in America's War on Terror, Patrick Hayden, Tom Lansford and Robert P. Watson, eds. (Aldershot: Ashgate, 2002), 55.

${ }^{159}$ Keegan, The Iraq War, 97.
} 
willingness to compromise on its Iraq policy during discussions with European leaders in May 2002. Powell observed that when the administration develops "a principled position, what we do is explain that principled position to our friends, try to see if we can find compromises, so we can join consensus. But where we can't join consensus because of our own beliefs, or because we believe a particular issue and the direction it's going with others does not serve the purpose intended by that action, the United States will stick to its principled position."160 A disregard for allied input was apparent in the manner in which NATO was asked to support American preparations for war with Iraq in the fall of 2002, without any suggestion that the Alliance be given command of the operation. Vice President Dick Cheney questioned the necessity of achieving a consensus among all of the United States' allies prior to taking military action in Iraq. He noted in a 2003 speech that the process of achieving consensus "though often couched in high-sounding terms of unity and cooperation, is a prescription for perpetual disunity and obstructionism. In practice, it would prevent our own country from acting with friends and allies, even in the most urgent circumstance." ${ }^{161}$ Unable to sway the members of the UN Security Council to support its position toward Iraq, the United States made it abundantly clear that it was willing to act unilaterally in defense of its interests. As hope faded for a UN Security Council resolution overtly authorizing the use of force against Iraq, an American official reportedly warned a member of another UN delegation, "You are not going to decide whether there is war in Iraq or not. That decision is ours, and we have already made it. It

\footnotetext{
${ }^{160}$ U.S. Department of State, "Press Briefing on the President's trip to Europe, May 28, 2002, http://www.state.gov/secretary/rm/2002/10516.htm.

${ }^{161}$ White House Office of Press Secretary, "Remarks by the Vice President to the Heritage Foundation, October 10, 2003," http://www.whitehouse.gov/news/releases/2003/10/20031010-1.html.
} 
is already final. The only question now is whether the Council will go along with it or not." ${ }^{162}$ The practice of collective security throughout this period was hampered by the absence of support for the regime among American leaders who placed greater emphasis on clearing the way for an invasion of Iraq than on achieving a clear international mandate.

An organization-based approach to regime analysis concentrates on the ability of NATO rules and procedures to encourage collective responses to the threats posed by international terrorism and WMD proliferation. Neoliberal institutionalists emphasize that the organizations resulting from international regimes can bolster the capabilities of any individual state, even a powerful hegemon, by pooling resources of a collective body. The advantages of cooperation allow states to achieve more optimal outcomes by providing access to information and resources that encourage participants to pursue long term cooperation over short term gains.

The threats of international terrorism and WMD proliferation seem particularly well suited to a collective response through an international regime. The nature of these threats is such that collective efforts are strongly favored over unilateral action. Terrorist attacks are generally very difficult to deter, as these groups are often characterized by high levels of secrecy, making it difficult to identify personnel or infrastructure that can be placed at risk. Deterrence is particularly difficult for a single state acting unilaterally, because terrorists can attempt to stay out of reach of counter-terrorism efforts by seeking refuge within the borders of other states or in parts of the world with little effective

\footnotetext{
${ }^{162}$ Karen DeYoung, "U.S. Officials Say UN Future at Stake in Vote; Bush Message Is that a War Is Inevitable, Diplomats Say," The Washington Post, February 25, 2003.
} 
governance. Counter-proliferation efforts must be focused on both potential sources of restricted materials and technology as well as the groups seeking them. These conditions mean that cooperation is needed among as many states as possible to monitor and take action against emerging threats.

Despite the suitability of collective responses to the threats of international terrorism and WMD proliferation, NATO failed to demonstrate considerable utility in these areas. Although numerous organizational changes were introduced in the decade following the Cold War, the vast majority of Alliance organizational structures "were designed for a threat and a world that no longer exists. They are not ideal for dealing with post-Cold War threats that are transnational and global rather than intergovernmental and European." 163 The characteristics of NATO organizations that made the Alliance essential to the conduct of ODF and OAF in the Balkans were less well suited to counterterrorism operations. As Francois Heisbourg, the Director of France's Foundation for Strategic Research, recently observed, "A political-military alliance designed to cope with a state-centered threat is not well geared to deal with non-state menaces such as $\mathrm{Al}$ Qaeda. Police work, non-military intelligence sharing, financial monitoring, and social and economic initiatives are not core competencies of NATO."164 The Alliance's core competency lay in its ability to organize and command multinational forces. This capability was only partially exploited in Afghanistan and Iraq due to the preferences of American leaders to act through an ad-hoc coalition.

\footnotetext{
${ }^{163}$ Gordon and Shapiro, Allies at War, 199.

${ }^{164}$ Steven Larrabee and Francois Heisbourg, "How Global a Role Can and Should NATO Play?" NATO Review 51, no. 1 (Spring 2003): 17.
} 
The rejection of NATO's standing arrangements in favor of an Americandominated command structure presents a challenge to the claims of many liberal institutionalists. Much of the Alliance's appeal to member states is based on the assumption that it is important to establish existing command relationships in advance of a crisis. These arrangements are intended to improve the responsiveness of NATO forces and improve their interoperability and effectiveness. The adaptation of the regime's established rules and procedures to cope with new threats is often more desirable than the creation of an ad-hoc coalition. The United States opted for the latter in the case of OEF, and the lack of consensus in advance of OIF prevented any other option from being pursued. Gordon and Shapiro conclude that "Europe's preoccupation with internal issues and its unwillingness to develop deployable military power lessened the perceived value of placating European opinion in ways that would have been given much higher priority in the past." 165 The fact that NATO leaders did not view the Alliance as providing a superior alternative to an ad-hoc coalition for the organization and command of combined military forces makes it difficult to characterize NATO as an independent international actor during this period.

The NAC authorized and directed supporting operations during OEF and OIF that were of a limited nature and somewhat independent of the primary counter-terrorism and counter-proliferation missions. Operations Eagle Assist and Operation Active Endeavor complemented coalition operations, but were not central to the objective of neutralizing Al Qaeda and removing the Taliban from power in Afghanistan. Several NATO bodies

\footnotetext{
${ }^{165}$ Gordon and Shapiro, Allies at War, 69.
} 
contributed to the GWOT by promoting intelligence sharing through the NIWS and by establishing a Civil-Military Planning Directorate with responsibilities for consequence management. NATO's WMD Center also enhanced information-sharing among both member and non-member states on numerous proliferation matters, but did not serve as an independent source for intelligence-gathering or enforcement operations. NATO organized no supporting operations during OIF, remaining absent from the theater until later organizing a small training contingent to assist in the reconstitution of Iraq's military and security forces. When compared to other aspects of GWOT that were carried out through other international regimes or bilateral agreements, NATO's contributions remained rather minor.

NATO was most successful in demonstrating its utility through its eventual leadership of post-war stabilization efforts in Afghanistan. Existing organizational capabilities and procedures were well suited to the post-Taliban stabilization effort, which resulted in NATO playing a leading role in this portion of the campaign. NATO procedures and consultative bodies helped prepare Alliance member and partner states for their role in ISAF. The Alliance's experience overseeing peacekeeping operations in the Balkans also resulted in well-tested rules and procedures that enabled NATO militaries to work alongside each other and gave their leaders a firm understanding of the demands likely to be placed on their forces. Exercises organized through NATO's PfP had prepared member and partner militaries to successfully conduct peacekeeping operations. As a result, ISAF was dominated by NATO member and partner states from its very inception in January 2002, and the NAC and SHAPE staffs were eventually 
called upon to coordinate the efforts of ISAF participants and perform vital command functions.

NATO's internal procedures requiring a full consensus among member states in advance of collective action meant that the Alliance was unable to unite either in support or opposition to the efforts of the United States to intervene in Iraq. Lord Robertson often reminded his peers that "Difficult, consensus-building negotiations are the essence of NATO." 166 However, the practice of collective security in accordance with existing rules and procedures allows all member states to exercising veto authority over the conduct of combined military operations. The intergovernmental nature of the Alliance meant that the NAC can facilitate existing agreements, but cannot institute an agreement among member states and NATO bodies have no means of preventing a minority of states from acting on their own. The ability of the United States to disregard the desires of its allies and proceed with military action in the face of strong allied opposition undermines the practice of collective security. European support for NATO is reduced as the allies realize that they have little input into the policies of the hegemon and that the Alliance has been reduced to a "joint training and exercise organization from which the United States can cherry pick 'coalitions of the willing' to participate in U.S.-led operations." 167

The reluctance of American leaders to comply with established norms of consultation and compromise added to divisions between the U.S. and Europe. Many

\footnotetext{
${ }^{166}$ George Robertson, "Transforming NATO," NATO Review 5I, no. 1 (Spring 2003): 2.

${ }^{167}$ Kitfield, "U.S. to NATO: Change or Else," 2979.
} 
European officials expected that the invocation of the Alliance's collective defense article would result in extensive consultations within the NAC and elsewhere. Decisions regarding the structure of a combined military force would be reached collectively, rather than from within the United States. A number of Europeans noted the United States' disregard for this fundamental aspect of diplomacy. According to one senior NATO official, "Part of the problem was that no one had ever done this before, and all of us had an image from our schoolboy days that after Article Five was invoked, the collective armies of the United States and Europe would march off together to slay a common foe. But this conflict is so unconventional that it didn't fit any of those stereotypes of what NATO was all about." 168

Instead of holding extensive consultations in advance of collective action, American leaders preferred to make specific requests for assistance under the condition that the United States maintain exclusive control over the pace and scope of military operations. The administration's disregard for meaningful consultation is apparent in President George W. Bush's recollection of a conversation he had with a European leader who advised him that "the best way to maintain the coalition was to have lots of consultation, for the U.S. to show responsiveness, take account of the views of others and understand their reasoning." President Bush responded, "Well that's very interesting. Because my belief is the best way that we hold this coalition together is to be clear on our objectives and to be clear that we are determined to achieve them. You hold a coalition

${ }^{168}$ James Kitfield, "NATO Metamorphosis," National Journal 34, no. 6 (February 2002): 376-380. 
together by strong leadership and that's what we intend to provide." 169 The policy positions of the United States and several key NATO allies were inflexible and NATO rules and procedures were ineffective at overcoming the resulting disagreements.

Different expectations regarding the conduct of the GWOT among the United States and many of its European allies were symptomatic of increasingly diverse expectations of international regimes in general. The process of European integration encouraged EU member states to develop high expectations for the potential contributions of international regimes. The success of the EU in stemming conflict among member states provided many Europeans with greater confidence in the ability of international regimes to contribute to international order. The EU increasingly behaved as a supranational actor, placing greater constraints on member states than the intergovernmental rules and procedures of NATO. The collection of regimes making up the EU emphasized the supremacy of community decisions over state sovereignty. The EU practiced qualified majority voting and member states were subjected to a variety of enforcement mechanisms qualitatively stronger than those of other international regimes. NATO's internal organizations had no such authority, with all proposals for collective action remaining subject to veto by a single member state. The need for consensus on even the more mundane aspects of campaign planning made American leaders reluctant to give NATO a larger role in OEF. The exclusion of the United States from the process of European integration served as another source of division within the Alliance that threatened to make the practice of collective security less likely.

\footnotetext{
${ }^{169}$ Woodward, Bush at War, 281.
} 
A norm-based approach to regime analysis contributes to an understanding of the process of regime change by emphasizing the significance of a sense of community among states participating in the regime along with a shared perception that this community was under threat. The boldness of the September 2001 attacks provided an incentive for Alliance members to overlook emerging differences and cooperate to disrupt Al Qaeda's ability to execute future attacks. The particular nature of the threat posed by Al Qaeda reinforced a common identity in a manner similar to the transatlantic identity formed in response to the shared threat of Soviet aggression. Osama Bin Laden's 1998 fatwah was directed not just at the United States, but its NATO allies as well. NATO member states recognized that Al Qaeda posed a fundamental threat to their sovereignty, as well as the shared values that defined their community. As liberal democracies, the United States and its European allies stood as open societies that were particularly vulnerable to international terrorism. The economic, military and political interdependence of NATO member states was such that a crippling terrorist attack on any NATO member states could be expected to have significant implications for all member states. Al Qaeda's decision to include the World Trade Center in its choice of targets also underscored the collective nature of the threat, resulting in the deaths of hundreds of foreign nationals from nearly 90 countries in addition to the devastating number of American casualties.

NATO leaders frequently acknowledged the persistence of a sense of community that enabled Alliance member states to view a terrorist attack on the United States as an attack on them. The Al Qaeda attacks gave the allies a temporary reprieve from the forces that were allowing the United States and Europe to drift apart and reinforced a 
perception of a collective identity rooted in shared values. General William Kernan, serving as SACLANT during OEF, referred to the common identity binding members of the Alliance, stating "It is as critical now to have a cooperative of democracies as it was during the Cold War. The threat to our collective security may have changed forms but the instability caused by nascent threats arguably places NATO nations at even greater risk than before." ${ }^{\prime 10}$ President George W. Bush sought to build international support for OEF both within NATO and elsewhere by emphasizing the role of common values. Following NATO's invocation of Article Five, he observed, "Many nations understand what NATO expressed, that an attack on us is really an attack on legitimate governments and on freedom." ${ }^{171}$ The invocation of Article Five and the wide range of both military and non-military actions undertaken by the Alliance were enabled by the existence of common values and interests among the United States and its European allies. As Secretary General Robertson stated, "Indeed, one of the clearest results of those tragic events has been a total affirmation that Europe and North America remain what they have been for over five decades: a rock-solid community of shared values."172

A norm-based approach to regime analysis also underscores the general agreement among regime participants regarding the legitimacy of the proposed collective course of action. The international norms shared by NATO member states viewed

\footnotetext{
170 "Interview with General William F. Kernan, Military Modernizer," NATO Review' 50, no. 3 (Fall 2002): 21.

${ }^{171}$ White House Office of Press Secretary, "Remarks by the President and NATO Secretary General Lord Robertson in Photo Opportunity, October 10, 2001," http://www.whitehouse.gov/news/releases/ 2001/10/2001 1010-6.html.

${ }^{172}$ NATO Office of Information and Press, "Speech by the Secretary General at the Annual Conference of the Defence and Society, January 21, 2002," http://www.nato.int/docu/speech/2002/s02012 la.htm.
} 
terrorism as an illegitimate form of political violence. These states agreed on international norms giving states a monopoly on the use of force, and collectively opposing the use of force by non-state actors. The use of military power either unilaterally or collectively was viewed as a legitimate means of retaliating against terrorists and their sponsors. The willingness of NATO member states to participate in both the military offensive and post-conflict operations was the result of an implied consensus on the proposed course of action that existed in spite of the absence of formal debate within the NAC. The European public also demonstrated a strong commitment to collective defense. European public opinion solidly supported military action in Afghanistan in the aftermath of the September 2001 attacks. Even in the midst of a divisive debate over the necessity for war with Iraq in the fall of 2002, the majority of Europeans surveyed in 11 out of 15 EU states "agreed with the U.S. military action" in Afghanistan. ${ }^{173}$ European support for war with Iraq was much smaller, in part reflecting the difficulty in perceiving a threat in advance of an Iraqi attack or clear evidence of a renewed Iraqi WMD program.

The perception of a threat posed by Iraq to the community of NATO states was not shared among American leaders and many of their European counterparts. In contrast to the clear act of aggression performed by Al Qaeda, there was no clear evidence of the existence of Iraqi WMD programs, nor was there a consensus over whether the existence of such weapons would pose an imminent threat to NATO member states. The practice of collective security is greatly complicated by the absence of a clear act of aggression, as

${ }^{173}$ Gordon and Shapiro, Allies at War, 191. 
discussed in previous chapters. With American vulnerability heightened in the wake of the September 2001 attacks, American leaders perceived Iraq's reluctance to cooperate with its disarmament obligations as a significant act of aggression. According to one set of analysts, "For Americans, September 11 changed the world; for Europeans, it changed America. Henceforth, Americans tended to see the world almost exclusively through the prism of international terrorism, whereas Europeans were still focused on the consequences of the end of the Cold War." ${ }^{174}$ During the run-up to the Iraq War, French Prime Minister Lionel Jospin cautioned, "The problems of the world cannot be reduced to the struggle against terrorism, however vital that struggle may be." ${ }^{175}$ American leaders were more inclined to perceive links between Iraq and international terrorism. President George W. Bush's declaration of an "axis of evil" consisting of Iraq, Iran, and North Korea emphasized his perception that the problems of rogue states and international terrorism were closely linked. European leaders pointed out the lack of clear evidence that Iraq had any direct links to Al Qaeda, noting the implausibility of close cooperation between the secular Iraqi government at the radical Islamists that controlled Al Qaeda. While both groups shared an antipathy toward the United States, they had little else in common.

American leaders were less tolerant of the status quo in the Middle East and expressed confidence that Iraq could be transformed into a stable, democratic state. Europeans familiar with the historical difficulties encountered by their governments'

\footnotetext{
${ }^{174}$ Gordon and Shapiro, Allies at War, 84.

175 Judy Dempsey, "Washington Turns Deaf Ear to Europe's Divided Voices," Financial Times, February 13, 2002.
} 
attempts to influence Middle Eastern politics throughout the $20^{\text {th }}$ century often felt that American leaders did not fully appreciate the difficulties inherent in the democratization of Iraq. British experiences with Iraqi rule in the early $20^{\text {th }}$ century along with France's experience in Algeria during the 1950s justified some skepticism regarding American ambitions in Iraq. European critics dismissed the idea that Western troops would be greeted as liberators by the Iraqi public and that Western forces could quickly succeed in rebuilding Iraqi society in the manner of post-World War II Japan and Germany. France's ambassador the United States, Jean-David Levitte, warned, "We see Iraq as a very complex country, with many different ethnic groups, a tradition of violence, and no experience with democracy. You can't create democracy with bombs."176 An alternative view of history introduced concerns that an Iraq dominated by foreign powers would implode into civil war and resemble Lebanon more than Germany or Japan. Even without this level of violence and chaos, critics pointed out that the invasion of Iraq would likely encourage more acts of international terrorism and therefore be counterproductive to the overall GWOT.

American leaders found themselves disagreeing with many European leaders on fundamental normative issues such as their understanding of international law and the legitimate use of force. European integration increasingly led European leaders to reconceptualize their view of security in a manner that emphasized non-military instruments of power, a contemporary view of security consistent with Buzan's new framework for security. The emerging view of security included issues of justice,

\footnotetext{
${ }^{176}$ Jean-David Levitte, “A Warning on Iraq, from a Friend,” The New York Times, Februrary 14, 2003.
} 
ethnicity, economic development, and transnational crime, in contrast to simply military views of security. One French diplomat characterized his American peers as tending "to emphasize military, technical and unilateral solutions to international problems, possibly at the expense of cooperative and political ones." 177 In the case of Iraq, this yielded an American preference for military coercion, while many European leaders expressed a preference for trade, technical, and financial incentives aimed at encouraging Iraq to comply with existing agreements.

The American strategy of preemption grew out of a growing willingness to employ military power to confront emerging threats. The relatively successful application of military power to foreign policy dilemmas in Bosnia-Herzegovina, Kosovo, and Afghanistan convinced American leaders of the utility of military force. Preemption had long been recognized as legitimate as long as there was a reasonable expectation of an imminent attack and strikes were proportional to the perceived threat. However, American leaders were widely accused of misapplying this doctrine toward Iraq and executing a preventive war against a remote and uncertain threat. One set of analysts described European reactions to the implementation of this doctrine as "the death notice of a rules-based international system and an end to their already limited ability to influence the American superpower." 178 Applying a strategy of preemption in this manner risked setting a dangerous precedent for conflicts in other regions and had potentially devastating consequences for the overall stability of the international system.

\footnotetext{
${ }_{61}^{177}$ Gilles Andreani, "The Disarry of U.S. Non-Proliferation Policy," Survival 41 (Winter 1999-2000): $42-$ 61.

${ }^{178}$ Gordon and Shapiro, Allies at War, 170.
} 
The United States might set a precedent that would encourage other states to resort to force more often to resolve international disputes. As Hanlon notes, "Countries already on the brink of war, and leaning strongly towards war, might use the doctrine to justify an action they already wished to take, and the effect of the U.S. posture may make it harder for the international community in general, and the U.S. in particular, to counsel delay and diplomacy." $" 179$ These concerns undermined support for American foreign policy both domestically and internationally.

A declining sense of transatlantic community was accompanied by an increasing sense of a European identity among a subset of European actors. Some scholars have observed significant differences between the emerging European identity and that of an American-dominated NATO. Manners and Whitman argue that while many international actors share a commitment to liberal-democratic principles, the identity of the EU is constructed around particular interpretations of these principles "such as social solidarity, anti-discrimination, sustainable development and good governance." 180 These scholars view the EU as pacific, which results in an identity that is different from the aggressive identity of NATO. Manners and Whitman claim that the EU does not seek the ability to wield military power to intervene in regional conflicts, rather "it seeks to moderate conflict in a more structural way by encouraging norms, which renders conflict not

\footnotetext{
${ }^{179}$ Michael O'Hanlon, Susan Rice and James Steinberg, The New National Security Strategy and Preemption: Policy Brief\#113 (Washington D.C.: Brookings Institution, 2002), 7.

${ }^{180}$ Ian Manners and Richard Whitman, "The Difference Engine: Constructing and Representing the International Identity of the European Union." Journal of European Public Policy' 10, no. 3 (June 2003):392.
} 
merely unthinkable but materially impossible." ${ }^{\text {181 }}$ Kagan similarly observes differences among European and American leaders on important normative issues such as "how the world should be governed, about the role of international institutions and international law, about the proper balance between the use of force and the use of diplomacy in international affairs." "182 These differences became more apparent as the European members of the Alliance expressed concern over U.S. foreign policy and determined how they would cope with the crisis over Iraq.

Many NATO governments found themselves pulled in different directions as a result of their allegiance to both the United States and their European neighbors. Europeanist governments, such as Belgium, France and Germany promoted a more distinct European identity and an active European foreign policy. These states had long been at the center of the European integration effort, although the EU's expanding membership threatened the influence of the founding governments. Europeanist leaders characterized their opposition to the use of force in Iraq as a united European position and used this issue to emphasize their special status within the EU. French President Jacques Chirac claimed wide public support among Europeans for his government's decision to challenge American ambitions in Iraq, and remarked to Latvian President Vaira Vike-Freiberga that "NATO was no longer relevant" to such disagreements. ${ }^{183}$ These and other attempts to establish a clear European position on Iraq under the

\footnotetext{
${ }^{181}$ Ibid, 390.

182 Robert Kagan, Of Paradise and Power: America and Europe in the New World Order (New York: Alfred A. Knopf, 2003), 3.

${ }^{183}$ William Shawcross, Allies: U.S., Britain, and Europe, and the War in Iraq (New York: Public Affairs,
} 
leadership of a handful of Europeanist governments were resisted by states concerned with the distribution of influence within the EU.

Concern over the consequences of French and German dominance within the EU along with a sense of obligation to the United States prompted a number of European governments to support American policies toward Iraq. Traditionally Atlanticist governments, such as Great Britain, Italy, and Poland welcomed a continued American role in European security affairs and were wary of EU incursions into security affairs traditionally reserved for NATO. Small countries, such as Luxembourg and Denmark viewed the United States' presence as a means of balancing the influence of their larger and more prosperous neighbors. Those European states that were new or aspiring members of NATO and the EU also generally supported the U.S. position. As Polish Defense Minister Radek Sikorski explained, "We supported the war in Iraq and have our troops there now not because we felt threatened directly by Saddam Hussein. We are there because of our investment in a strong U.S.-Polish relationship. We want to show the United States we will be with them when we are needed." "184 Asmus finds that for many of these governments "their instincts on how Europe should be structured and governed will tend not to be federalist but inter-governmental. Having just joined the European Union, they will be reluctant immediately to embrace far-reaching, integrationist schemes that force them to cede more sovereignty to Brussels. Above all, they will want to maintain an American presence and influence in European affairs. Many of them still

\footnotetext{
${ }^{184}$ David Sands, “Allies See Benefits in Iraq Missions," Washington Times, December 9, 2005.
} 
want more America in Europe, not less." 185 Division within Europe combined with the unilateralist tendencies of the United States contributed to a breakdown in a sense of community and lessened the willingness of NATO member states to broaden their commitment to the practice of collective security.

\section{Conclusion}

This study has examined how NATO contributed to the GWOT and the utility of various approaches to regime analysis to gaining an understanding of the Alliance's changing commitment to collective action. NATO member states remained committed to their collective defense pledge while expressing numerous reservations to the extension of a collective security regime to threats emerging outside of Europe. Shortfalls in many of the factors associated with the various approaches to regime analysis can be associated with the difficulties encountered by the Alliance as it attempted to extend its commitment to a collective security regime. NATO allies expressed solidarity with the United States through the invocation of the Alliance's collective defense clause following the attacks by Al Qaeda, based on a continued sense of community and a shared perception of the threat posed by international terrorism. However, American leaders found NATO's consensual decision-making processes too cumbersome to deliver satisfactory results in the desired timeframe, sidetracking efforts to gain a larger role for the Alliance. In contrast to earlier military interventions in Europe, the Alliance ended up playing a supporting role to the American-led coalition conducting counter-terrorism operations in Afghanistan. Shortly after the fall of the Taliban, the allies failed to reach a consensus on

\footnotetext{
${ }^{185}$ Ronald Asmus, “Great Expectations,” NATO Review 51, no. 2 (Summer 2003): 30-2
} 
the necessity of a military confrontation with Iraq. American leaders failed to advocate a leadership role for the Alliance, once again expressing dismay for the inability of NATO bodies to quickly assemble determined and capable forces. In turn, Europeans felt less of an obligation to lend support on American terms due to the absence of persuasive evidence of Iraqi violations of international agreements or a clear act of aggression that would once again justify an appeal to a collective defense regime. Intra-alliance disputes were accompanied by a breakdown in the sense of community among NATO member states brought about by American views of exceptionalism and continued efforts among some EU member states to promote a distinct European identity. The recent difficulties encountered as NATO leaders struggled to define the conditions under which it would practice collective security further demonstrate the utility of the various approaches to regime analysis. The final chapter of this dissertation will review these findings and offer recommendations for future reforms aimed at overcoming some of the recent obstacles to collective action and enhancing the Alliance's role as a source of international stability and security. 
There is nothing more difficult to carry out, nor more doubtful of success, nor more dangerous to handle, than to initiate a new order of things.

- Niccolò Machiavelli (1513)

Chapter 5: Discussion and Conclusion

This research has examined the evolution of NATO as an international security regime both during and after the Cold War. NATO's commitment to a collective defense regime after World War II provided for the peaceful rearmament of former enemies for the common purpose of countering Soviet expansionism. Along with organizing allied forces for the credible defense for Western Europe, the Alliance developed many mechanisms to promote transparency, cooperation and collective action, thus reducing the reemergence of security dilemmas among former enemies. Changes in the international security environment following the dissolution of the Soviet Union provided the impetus for the Alliance to adopt additional characteristics of a collective security regime while maintaining its commitment to collective defense. This research has examined the process of regime change as NATO attempted to introduce collective security functions in addition to its collective defense responsibilities. NATO member states accepted new missions and emphasized new capabilities in the aftermath of the Cold War as they worked together to expand the level of cooperation among themselves and neighboring states. The allies' commitment to collective security differed during this period between security challenges emerging from within Europe and those emerging outside of Europe. A common commitment to preserving peaceful relations among regional actors encouraged NATO's increased engagement with non-member states and the Alliance's command of several military interventions to restore peace within Europe. 
While NATO successfully carried out two military interventions in the Balkans in accordance with the collective security ambitions espoused by many NATO leaders, the Alliance played much less of a role in out-of-area military operations associated with the Global War on Terrorism (GWOT). The support provided to the United States in Afghanistan was in great part due to the allies' interest in preserving a collective defense regime rather than a wholesale commitment to extending the practice of collective security beyond Europe. Disregard for the practice of collective security toward out-ofarea threats was evident in events related to Iraq's alleged development of Weapons of Mass Destruction (WMD). The lack of consensus among Alliance members prevented NATO from playing a significant role before, during, or after the invasion of Iraq. This research offers insights into the nature of international regimes and the process of regime change, and has yielded recommendations aimed at increasing NATO's viability as a source of greater security and more meaningful international cooperation.

\section{Overview of Findings}

This research has resulted in a number of findings related to the behavior of states toward international regimes and the process of regime change within NATO. Each of the three approaches to regime analysis identified in my typology of power-based, organization-based and norm-based approaches to regime analysis contribute to an understanding of these topics. These approaches have been utilized to identify several factors that appear to have some influence on the process of regime change. These factors include hegemonic leadership, access to relevant capabilities, and a sense of community. The Alliance's disposition towards the regimes of collective defense and collective security can be viewed through the interplay of these factors. My analysis of 
NATO both during and after the Cold War has shown a correlation between the presence of these factors and a shared commitment to collective action. The absence of these factors is correlated with internal conflict and inaction, as observed most recently during the debate over the Alliance's role in the GWOT.

This research provides support for the utility of a power-based approach to regime analysis and the necessity of hegemonic leadership to the process of regime change. The United States bore much of the responsibility for the defense of Europe both during and after the Cold War, providing assurances to its European allies that allowed for some moderation of the security dilemmas that had led to recurring conflict among these states. As the alliance hegemon, the military capabilities of the United States greatly exceeded those of its allies and gave American leaders a large voice in determining Allied strategy. Periods of indecision and inaction on the part of the Alliance can be associated with an absence of American leadership while many of the initiatives embodying regime change were sponsored by American leaders. The interests of the United States, which continues to play the role of alliance hegemon, have remained compatible with a collective defense regime and the practice of collective security within Europe. In the case of out-of-area operations, American leaders have shown that they are not always interested in compromising on the objectives or pace of military operations for the sake of preserving alliance cohesion. The United States seeks to preserve its access to European forces and facilities, but does not want the conduct of its operations constrained. These unilateralist tendencies serve as one obstacle to the extension of NATO's commitment to collective security. The hegemonic power of the United States depends in no small part on its ability to sustain an international order and to commit itself to the rules of that order. The 
United States must make efforts to assure that the appropriate rules and procedures are in place, and that suitable capabilities are present to ensure the success of collective endeavors.

This research also provides support for the utility of an organization-based approach to regime analysis and the ability of international organizations to influence the process of regime change by providing access to relevant capabilities. American leadership has been crucial to persuading the rest of the allies to act, although this leadership alone is not a sufficient condition for collective action. Organizational capabilities greatly determine the amount of influence that an international institution will have in a particular issue area. Security is a particularly challenging task for the creation and enforcement of international regimes due to concerns over sovereignty and relative gains. The intragovernmental nature of NATO decision-making structures is important to preserving sovereignty, but has made it all the more difficult for the Alliance to act. An international security organization must demonstrate the ability to summon relevant capabilities in order to make multilateral responses favorable over unilateral action.

From an organizational perspective, NATO made a number of important contributions to transatlantic security during the Cold War, even if it did not substantially alter the hegemonic status of the United States. NATO's role in shaping questions of strategy has been directly proportional to the perceived advantages of collective action to various threats. The military capabilities of NATO member states and the effectiveness of NATO command structures greatly influenced the adoption of a collective security regime within Europe in the post-Cold War era. More than forty years of experience developing plans for the defense of Western Europe resulted in a close integration of 
national military staffs and the NATO staff assembled at Supreme Headquarters Allied Powers Europe (SHAPE). NATO member states also maintained relationships with regional actors and non-member governments that could be exploited to support diplomatic initiatives aimed at avoiding armed conflict or successfully executing military interventions in territory within or contiguous to that of NATO member states.

This final element of international cooperation is explored in this research through the application of a norm-based approach to regime analysis emphasizing the importance of a shared sense of community to the maintenance of existing international regimes and the process of regime change. The perception of a transatlantic community has suffered setbacks both within the United States and Europe. The United States' preponderance of military power and its global presence have contributed to the emergence of a unique identity based on claims of American exceptionalism. This phenomenon is characterized by one observer as a firm belief among American leaders in the "superior principles of public and interstate behavior" embodied by the United States. ${ }^{1}$ American leaders sought to take advantage of opportunities created by the fall of the Soviet Union and secure the United States' status as the sole global power. The perception among American leaders that they hold unique global duties and responsibilities has made them less willing to acknowledge the viability of its allies' views and the unquestioned military superiority of the United States has given them a preference for military solutions to security problems. The rise of the EU and efforts to promote a distinct European identity have contributed to a breakdown in the perception of a transatlantic community within Europe. To some

\footnotetext{
' John Keegan, The Iraq War (New York: Alfred A. Knopf: 2004) 97.
} 
European leaders, a more united Europe offers the possibility for a rebalancing of power across the Atlantic, with an independent Europe acting on more equal terms with the United States. The EU's efforts to promoted greater social and economic integration have led some Europeans to conclude that such nonmilitary initiatives hold great promise for a more peaceful international order. Self-interested EU bureaucrats tend to reinforce the concept that the EU must succeed NATO as the guarantor of European security, claiming that NATO is no longer able to provide Europeans with sufficient opportunities to influence the security of Europe and other important regions.

Despite the claims of some practitioners and theorists, there is little evidence of a single European identity that can be easily contrasted with a clearly defined transatlantic identity. According to Hodge, "The Iraq crisis had demonstrated further that a common European foreign policy would remain a vain hope for the next twenty years."2 Europe remains divided between those governments that view the EU's transition into security affairs as a means of gaining greater influence over important security issues and those states that are reluctant to abandon the NATO security structure. Many NATO governments, including NATO's newest members, tend to free ride on the efforts of the United States, and do not wish to exchange NATO's current security arrangements for an untested arrangement dominated by a handful of their larger neighbors. Divisions remain over the role of military and nonmilitary instruments of power, with several governments tenaciously defending their support for the American-led invasion of Iraq. The leaders of many smaller European NATO states are wary of ceding NATO authority

\footnotetext{
${ }^{2}$ Carl Hodge, Atlanticism for a New' Century: The Rise, Triumph, and Decline of NATO (Upper Saddle River, NJ: Prentice Hall, 2005), 96.
} 
to the EU for fear that they will be underrepresented in a regime that does not practice decision-making through consensus. Their leaders do not want to have to choose between NATO and EU and wish to find a way for the two regimes to coexist in a complementary manner.

The conditions of hegemonic leadership, access to relevant capabilities, and a sense of community were adequately fulfilled toward the maintenance of a collective defense regime both during and after the Cold War. The defense of Western Europe from the threat posed by Soviet aggression was considered vital to the security of the United States as well as its European allies. This task demanded the close cooperation between NATO militaries and the development of complementary capabilities. NATO came to embody a sense of transatlantic community, with a collective identity largely defined as a shared opposition to the Soviet threat and an adherence to democratic norms. European leaders recognized their dependence on the United States during the Cold War and accepted American leadership. The United States continued to reassure its European allies of its commitment to the practice of collective defense even after the end of the Cold War, which served as the primary motivation for the eastward expansion of the Alliance among states seeking security assurances and better relations with the rest of Europe.

The practice of collective security in Europe following the end of the Cold War was a result of American leadership utilizing the residual capability developed for the purpose of collective defense. The United States could not effectively act within Europe without the participation of its European allies, thus making collective action through NATO a desirable option to American leaders. The shared desire of the allies to bring an 
end to the violence in the Balkans presented an opportunity for NATO to expand its mandate into collective security. American leadership made military operations through NATO possible, while European militaries made crucial contributions in the form of troop contributions, access to key facilities, and support for diplomatic initiatives. NATO member states maintained a sense of community based on their commitment to maintaining stability throughout the European continent while encouraging continued democratic reforms in former Warsaw Pact states. A combination of these enabled NATO to successfully adopt a collective security regime in response to a breach of the peace within Europe.

The conditions favoring the practice of collective security within Europe could not be uniformly applied to threats originating from other regions. The capabilities of European members of NATO were not as well-suited to operations outside of Europe, which reduced both their willingness to participate in out-of-area collective security mission and reduced the desirability of acting through the Alliance to American leaders. Capabilities shortfalls exposed during NATO's operations in the Balkans demonstrated that European military forces remained optimized for operations within their own borders. These states could not project military power as effectively as the United States and European governments failed to follow through with reforms aimed at closing the capabilities gap among NATO military forces. Crises resulted from both a lack of collective military power as well as a political disagreement over the use of military power. Differences in the perception of the threat posed by the nexus of international terrorism and WMD proliferation also contributed to a breakdown in the sense of community among NATO member states. American leaders felt a sense of urgency 
following the Al Qaeda attacks of September 2001 that was not shared by their European allies. A perception of increased vulnerability contributed to unilateralist tendencies already emerging from the differences in military capabilities. American leaders began to view NATO participation as less than essential to the successful outcome of military interventions in both Afghanistan and Iraq, while many European governments expressed a preference for nonmilitary courses of action. While many European governments were pursuing greater economic and social integration through an increasingly competent European Union, a decreased sense of interdependence emerged among American and European leaders that further limited compliance with the norms of consultation and compromise that had historically characterized relations among NATO governments.

The difficulties encountered by NATO in the adoption of a collective security regime are consistent with many of the forecasts of some regime theorists. As noted in Chapter One, Claude and other theorists have contrasted the rather straightforward view of international aggression enshrined in many collective defense arrangements with the more uncertain judgments of international aggression necessitated by the practice of collective security. The disparate roles of the Alliance in the 2001 Afghanistan War and in the 2003 Iraq War were determined in no small part by the ease in which an overt act of aggression could be perceived. The Alliance was much more decisive and effective in response to a security crisis that could be portrayed as meeting the criteria of a collective defense scenario than one that involved the more subtle determinations of aggression commonly associated with the practice of collective security. NATO member states have struggled with issues similar to those undermined earlier attempts to practice collective security throughout history. Although states may agree in general about the desirability 
of a peaceful international order, the specific circumstances surrounding attempts to enforce such an order offer many opportunities for disagreement. Rival views on the necessity for collective action can become even more disparate when the events in question occur far away and involve less than vital interests.

In many ways, the disposition of member states toward the practice of collective security outside of Europe has not changed greatly since the end of the Cold War. Some observers view the lack of concurrence over Iraq as evidence that the Alliance has not undergone a fundamental transformation since the end of the Cold War. A comparison of member state behavior during the Suez Canal crisis of 1956 and the conflict preceding the 2003 Iraq war demonstrates the difficulties NATO continues to experience regarding the practice of collective security outside of Europe. Kissinger notes a number of similarities between the rationale used by Europeans leaders opposing the use of force in Iraq to the rationale used by American leaders opposing France and Great Britain's use of force during the Suez Canal Crisis. In each instance, NATO member states opposing the use of force argued "that allied obligations were circumscribed by a precise legal charter [and] that recourse to force was admissible only in strictly defined self-defense." $3 \mathrm{He}$ also observes a willingness among NATO governments both then and now to improve their relations with a strategically important Middle Eastern state at the expense of a fellow NATO ally.

NATO's continued commitment to a collective security regime faces an uncertain future. While many European states wish to pursue long-term gains associated with the

\footnotetext{
${ }^{3}$ Henry Kissinger, "Role Reversal and Alliance Realities," The Washington Post, February 10, 2003.
} 
continued engagement of the United States, others wish to explore greater independence in security affairs. NATO's collective defense pledge is commonly cited by NATO leaders as the most valuable aspect of alliance membership, driving both the desire to join the Alliance and the willingness to support the policies of the hegemon. While there is a general interest in preserving the Alliance's collective defense regime, the United States and its European allies are less certain regarding the practice of collective security. American leaders recognize the value of allied contributions to military interventions and peacekeeping operations both within Europe and elsewhere, but remain concerned regarding undue limitations on their freedom of action. Most European governments desire access to American military and diplomatic capabilities, but have made it clear that they will not accept an unconditional obligation to participate in military interventions outside of Europe. While NATO has managed to adapt to changing circumstances in the past, the Alliance cannot be expected to withstand a wholesale divergence of interests among its members.

International regimes must continually demonstrate their value or risk becoming outmoded and irrelevant. Just as military alliances can be reformed or broken, international regimes may reach a breaking point where the termination of the regime is determined to be in the best interest of its members. Once flourishing regimes have been abandoned in the past as the relationships between participants change or the entities emerge. NATO's survival depends on the Alliance's ability to overcome limitations imposed by materiel, territorial, and ideational differences among its member states.

Material differences are embodied in the growing "capabilities gap" that has been observed between the United States and the rest of its NATO allies. The expeditionary 
nature of American military forces emerging from the Cold War allowed them to be quickly realigned in response to international events. In contrast, Allied militaries lacked key capabilities to make their forces easily transportable and supportable well outside their borders. Greater investment by the United States in military technology throughout the post-Cold War era further aggravated the differences between American and Allied military forces. Interoperability problems observed during NATO operations in the Balkans reduced the perceived utility of combined force structures. Differences in the relative capabilities of NATO militaries shaped both American and European views toward to use of force and fueled American views of "exceptionalism" along with a growing disdain for combined operations.

Territorial limitations have been apparent in the Alliance's inability to extend the practice of collective security outside of Europe. The capabilities of European member states and NATO organizational bodies meant the Alliance played a unique role in the execution of military interventions within Europe. The combined military, diplomatic, and economic efforts of the United States and its NATO allies gave the Alliance a unique standing within Europe. However, the Alliance's ability to actively address the outbreak of conflict in Europe was less relevant to conflicts originating from outside of Europe. Many European member governments are unable or unwilling to invest in more expeditionary militaries and face public opposition to military endeavors that do not impact their vital interests. Despite many external and internal reforms, NATO has struggled to achieve the unity of will necessary to allow member states to collectively address out-of-area threats. 
Ideational differences have manifested themselves in the debate over the future role of the United States in Europe and the desirability of an independent European security regime. During the Cold War, the overt threat posed by the Soviet Union helped to sustain NATO's collective defense regime along with the formation of a sense of community rooted in a shared commitment to the expansion of liberal values. In a more complex and multifaceted security environment, differences in the perception of threats and the absence of a common identity have made the practice of collective security less practical. The absence of a clear sense of identity either exclusive or inclusive of the United States has presented another barrier to the practice of collective security. As Erlanger observes, "The use of force will always be controversial in a European Union that has no clear identity, no single citizenship or army, and no larger European patriotism for which, so far, any young European man or woman is likely to want to die in battle." ${ }^{4}$ The United States and its European allies continued to adhere to longstanding norms of consultation and compromise regarding traditional military planning, but have encountered difficulties expanding these norms to emerging threats. While NATO member states have consistently demonstrated their interest in preserving a collective defense regime, there is less certainty regarding the Alliance's further extension of a collective security regime.

NATO must overcome these material, territorial, and ideational challenges if it is to continue to play a meaningful role in the preservation of transatlantic security. While one cannot rule out the possibility that chronic differences among NATO member states

\footnotetext{
${ }^{4}$ Steven Erlanger, "Anatomy of a Breakdown," in Beyond Paradise and Power: Europe, America and the Future of a Troubled Partnership, ed. Tod Linberg (New York: Routledge, 2005), 15.
} 
may eventually lead to the dissolution of the Alliance, the implications of this research suggest that transatlantic cooperation may be sustained and even expanded in the future through a process of reform addressing key factors associated with power-based, organization-based, and norm-based approaches to regime analysis.

\section{Implications of research}

This research supports a number of policy recommendations for both member state governments and NATO leaders wishing to increase the present level of transatlantic cooperation while recognizing NATO's present capabilities and limitations. The preservation and expansion of collective security regime within and beyond Europe requires NATO leaders to address factors associated with all three approaches to regime analysis. NATO must seek to overcome the skepticism of American leaders who question the need for the United States to act through the Alliance by improving its access to relevant capabilities. NATO must demonstrate the ability to foster commitments to collective action and carry out these decisions through an effective command structure. The United States and its European allies need to explore ways of improving their existing security dialogue and restore a shared sense of community, in order to aid the formation of common security policies and greater consensus regarding the perception of emerging threats.

The abandonment of NATO is not an attractive option for the United States or its European allies. The loss of NATO would eliminate a useful transatlantic bridge that promotes an important dialogue that helps member states understand each other's security needs and identify opportunities for cooperation. An end to this dialogue could trigger security dilemmas and the resumption of overt power balancing within Europe. 
European states could find their efforts at further integration slowed by an erosion of trust among member governments. The United States might find it more difficult to act in the region, since its presence is dependent on the concurrence of its allies and their willingness to provide access to important facilities along with transit rights. Any efforts to quickly organize and deploy combined military forces would be hindered by the absence of standing forces or the maintenance of common standards and procedures for such missions. The termination of efforts to assure the interoperability of American and European military forces would increase the risk of future combined operations failing to fulfill their mandate.

The United States' current preference for acting through "coalitions of the willing" reflects dissatisfaction with the procedural characteristics of existing international organizations rather than a uniform desire to pursue its interests in isolation. The key to reviving NATO as a suitable vehicle for the pursuit of multilateral policies is to improve the Alliance's ability to reach agreement on the necessity for collective action and to make suitable forces available to carry out the resulting decisions. NATO may find it possible to extend its commitment to collective security outside Europe by addressing chronic problems with its command structures and the distribution of military capabilities.

Improvements in the capability of NATO military forces is one clear way of reversing the division of labor where American forces provide the bulk of combat forces while Europeans are later tasked with peacekeeping responsibilities. This division of labor has introduced frustration and resentment among European leaders that feel they are not given an opportunity to provide sufficient input regarding operations that affect their 
security. The ability of European states to influence American foreign policy will continue to be closely tied to the perception that these states can provide crucial assistance to the United States. NATO can retain its relevance only if its member states obtain military capabilities that are demanded in the event of a crisis. As General Jones, the Supreme Allied Commander Europe (SACEUR) observed, NATO "has too much capacity for what it used to do in the past and not enough capacity for what it must do in the future. In order to retool effectively, tough decisions must be made in order to free up resources to invest for the future." Despite a European gross domestic product that far exceeds that of the United States, the combined defense spending of the European members of NATO is less than half of that of the United States. If European leaders do not have the political will to significantly increase defense spending, they should work to develop agreements on how their limited resources can best be allocated to reduce the capabilities gap between their military forces and those of the United States. An increase in the number of combined weapons systems development programs, an elimination of unnecessary duplications in the European defense industrial base, and reductions in the numbers of non-deployable support personnel are just some of the ways to increase the effectiveness of European military forces with little or no spending increases.

NATO leaders should seek new ways of enforcing existing agreements regarding defense spending and capability improvements. A majority of NATO member states have regularly failed to sustain defense budgets at the "minimum" level of $2 \%$ of Gross

\footnotetext{
5James Jones, "Military Matters: Transforming NATO's Military Structures," NATO Review' 52, no. 1 (Spring 2004 ) http://www.nato.int/docu/review/2004/issue l/english/military.html.
} 
Domestic Product (GDP) over the past several years. ${ }^{6}$ While joint force structure goals, such as those announced during the June 2004 Istanbul Summit, help to specify the direction of future reforms, these goals have rarely been met. ${ }^{7}$ NATO does not currently have a means of enforcing past agreements and the intragovernmental nature of the Alliance makes it unlikely that penalties can be effectively applied. An alternative may lie in an incentive structure where small NATO states are encouraged to develop niche capabilities that help the Alliance meet their force projection objectives. These states should be discouraged from attempting to develop military forces capable of conducting the full spectrum of military operations, recognizing that such a capability can only be affordably attained through the combined deployment of NATO forces. A number of NATO allies have already reshaped their forces to eliminate redundancies and focus on providing capabilities less commonly available within the Alliance. In recent years, Denmark abolished its submarine force, greatly reduced the size of its air defense system and eliminated the Multiple Launch Rocket System (MLRS) from its inventory. According to the Danish Minister of Defense, these decisions were reached "with a view to what NATO needed and what was most required for international operations." ${ }^{8}$ The

\footnotetext{
${ }^{6}$ A review of 2004 defense spending shows that Belgium, Canada, the Czech Republic, Denmark, Estonia, Germany, Hungary, Italy, Latvia, Lithuania, Luxembourg, the Netherlands, Portugal, Slovakia, Slovenia, and Spain remain below the $2 \%$ of GDP. NATO Office of Information and Press, "Statistics: Defense Spending and Military Personnel," http://www.nato.int/docu/review/2005/issue3/english/statistics.html.

${ }^{7}$ During this summit, NATO defense ministers agreed that $40 \%$ of each member state's land forces should be capable of being deployed as part of combined operations under NATO or other auspices, and that $8 \%$ of these forces would either be engaged in or earmarked for such operations at any time. These targets have yet to be met by most NATO governments.

${ }^{8}$ NATO Office of Information and Defense, "Speech by H.E. Mr Søren Gade Minister of Defense, Denmark, The Danish Response to the Transformation Challenge, April 14, 2005," http://www.nato.int/docu/speech/2005/s050414c.htm.
} 
Danish example should be followed by other European member states that wish to field forces that are capable of operating alongside each other under a range of combat conditions

Another promising area of improvement relies on increasing the size and capability of the NATO Reaction Force (NRF). Current plans for the NRF will give NATO the ability to deploy a brigade-size force capable of high-intensity combat operations at short notice. NRF assets are identified in advance along with procedures for transport, communications, logistics, and intelligence related to operations within or outside of Europe. Once these initial goals are reached, the NRF could be expanded to multiple brigades or potentially larger troop formations. The NRF should also be expanded to include personnel and assets required to address the multitude of nonmilitary tasks that accompany peacekeeping and reconstruction operations. In both Afghanistan and Iraq, coalition forces demonstrated impressive war-fighting capabilities, but were less successful in post-conflict stabilization efforts. NATO's limited expertise in civil functions may require close coordination with other state agencies or international organizations. Regardless of where these capabilities are found, the emphasis on advanced planning that accompanies NRF operations can help assure that the right mix of resources are available to ensure that both combat and post-conflict operations are successful.

An increased emphasis on the organization of standing military forces such as the NRF could be complemented by the creation of a common fund for NATO operations. NATO's annual budget is presently limited to the costs associated with the NATO headquarters staff along with the costs of acquiring and maintaining common equipment 
and facilities. This budget is on the order of only one percent of combined defense spending because the vast majority of troops and equipment for NATO operations are provided directly by participating states. The current arrangement discourages the poorer members of NATO from contributing troops even in the event that the forces are available and the government fully concurs with the objectives of the operation. A common operations fund would facilitate greater overall participation by allowing those member states willing to deploy forces to be subsidized by other states that are either unwilling or unable to deploy their own forces in support of a particular mission. This initiative not only has the benefit of making more forces available for deployment, but it has the potential to improve the training and interoperability of NATO forces by giving less-capable member states the opportunity to gain more experience employing NATO doctrine and complying with NATO standards.

Common funding has long been practiced as a means of funding UN peacekeeping operations, and is worthy of further consideration by NATO member states. Common funding has been practiced within NATO on a limited scale with the creation of the NATO Airborne Early Warning Force. As General Jones, SACEUR, recently observed, "We have a good example in the Alliance of success in common funding operational deployments, and that is you have to look no further than NATO AWACS...We don't spend a lot of time worrying about using NATO AWACS with regard to who's going to pay for it, because it's already resourced. And so it does a lot of 
things, it goes a lot of places." ${ }^{9}$ NATO operations, along with key capabilities such as strategic airlift and ballistic missile defense are all attractive candidates for common funding. Poland's role in Iraq provides one example of why this arrangement is desirable. According to the Polish Minister of Defense, Radek Sikorski, operations in Iraq since 2003 have cost Poland $\$ 600$ million to date, and has forced Poland to delay some of the modernization of its military forces it had agreed to in previous NATO summits. ${ }^{10}$ Polish leaders are concerned about having to commit as much as $10 \%$ of their annual defense spending to Iraq, and have asked the United States to increase its military aid to Poland to help offset this expense. Common funding can help reduce the competition between modernization and current operations that plague the Polish government along with those of other NATO member states.

Even with more capable and interoperable military forces, NATO's continued evolution toward the practice of collective security will remain stalled until significant changes take place reflecting the organizational and normative characteristics of the Alliance. NATO leaders desiring the Alliance to have a more active role in global security affairs should pursue streamlined decision-making procedures and the ability to quickly field large numbers of combat-ready forces operating under effective command arrangements. The goals of these reforms are to help NATO member states make decisions and to take the necessary action necessary to carry out these decisions. As

\footnotetext{
${ }^{9}$ NATO Office of Information and Press, "Remarks by General James L. Jones, Supreme Allied Commander Europe, What has NATO learned from its operations? April 14, 2005, http://www.nato.int/docu/speech/2005/s050414i.htm.

${ }^{10}$ Christopher Cavas, "Polish Minister, Rumsfeld Discuss NATO Issues," Defense New's, December 12 , 2005.
} 
Bulgaria's Minister of Defense, Nikolay Svinarov, recently observed, "The real test for the success of our policy is the compatibility of the declarations and their practical realization, the synergy of words and actions, which practically means our capacity and skill to successfully translate the political declarations and the intentions into a clear, practical language, followed by concrete and adequate actions." 11

The reform of NATO's decision-making procedures should be considered in the interest of allowing the Alliance to become more active in world affairs. The North Atlantic Council (NAC) and other internal bodies have long operated on the principle that a consensus must be achieved among all member states in order for the Alliance to act, and all members have a veto. Collective action problems stem from the need for consensus among all 26 member states prior to the Alliance's involvement in an issue area. Achieving unanimity is within the NAC is a time-consuming process that limits the responsiveness and flexibility of NATO forces. A larger membership introduces more opportunities for dissension and the possibility that the concerns of a small minority of states will prevent the majority from taking action they deem necessary for their security. NATO has faced a number of such deadlocks, including the initial refusal of aid for the defense of Turkey in the run-up to war with Iraq. NATO leaders should consider introducing procedures for the initiation of operations based on the will of the majority. Procedural changes permitting decision-making through a simple majority rule, or a weighted majority based on monetary or troop contributions are worth scrutinizing. One solution might lie in the concept of constructive abstention practiced within the EU,

\footnotetext{
${ }^{11}$ NATO Office of Information and Press. "Address by Nikolay Svinarov, Minister of Defence, Bulgaria Transforming NATO - A Political and Military Challenge? April 14, 2005," http://www.nato.int/docu/ speech/2005/s050414g.htm
} 
wherein a state can elect not to implement a decision reached by the majority while agreeing not to impede the actions of the majority. Democratic leaders are well-versed in the practice of compromise and adhering to the will of the majority, which makes it all the more likely that a suitable arrangement could be crafted.

NATO leaders may also look to the United Nations as a model for how to oversee ongoing operations. The NAC is much more actively involved in the management of military operations than the UN Security Council. James Dobbins, a former U.S. Assistant Secretary of State for Europe, observes that while "the [Security] Council normally makes only one decision respecting any particular operation every six months, leaving the UN Secretary-General relatively unconstrained in carrying out that mandate during the intervals, the North Atlantic Council's decision-making is more incremental." 12 While this level of involvement is intended to give member state the necessary reassurance to allow them to commit to more high-risk operations, it has instead resulted in slow responsiveness, frequent redirection and the restrictive rules of engagement (ROE). Numerous national caveats on the use of forces place unnecessary constraints on operational commanders. Security assistance operations in Kosovo were recently disrupted when several participating governments imposed restrictions on the use of their forces in riot control. Other member states imposed a requirement that their governments be given twelve hours notice before their troops could be deployed outside of a designated geographical area. Describing the impact of inconsistent ROE, U.S. Secretary of Defense Donald Rumsfeld observed, "It's kind of like having a basketball

\footnotetext{
${ }^{12}$ James Dobbins, "NATO's role in nation-building," NATO Review 53, no. 2 (Summer 2005) ttp://www.nato.int/docu/review/2005/issue2/english/art l.html.
} 
team, and they practice and practice and practice for six months. When it comes to game time, one or two say, 'We are not going to play."'13 In order to assure the successful outcome of future operations, NATO commanders must be given the authority and flexibility to make operational decisions without undue interference from the NAC or other political bodies.

NATO's effectiveness as an international security regime can also be enhanced by a more productive relationship with the other similar regimes, such as the EU. Some American officials have advocated a division of labor through which the United States shifts its attention to threats outside of Europe while transferring the responsibility for European security to the EU or another international organization with exclusively European membership. ${ }^{14}$ In practice, such a division of responsibilities along geographic boundaries could introduce innumerable difficulties. Many contemporary security challenges are transnational and cannot be contained to single region. This approach fails to recognize that out-of-area threats quite often affect the interests of European states, sometimes to an even greater extent that those of the United States. Since so many of these threats can be more effectively countered with collective action, a more productive approach is to seek a way to reform existing relationships to draw on the combined resources of all like-minded states rather than imposing barriers to action. Blanket opposition to European integration among American or NATO leaders will simply encourage call for the emergence the EU as a counterweight to American power.

\footnotetext{
${ }^{13}$ Philip Shishkin, "NATO's Peacekeeping Problem," Wall Street Journal, August 8, 2005.

${ }^{14}$ Stephen Larrabee, NATO's Eastern Agenda in a New Strategic Era, (Santa Monica, CA: RAND, 2003), 177.
} 
American officials should avoid trying to highlight differences between "old Europe" and "new Europe" because any unresolved differences among European states weakens the commitment to collective action. While the Central and Eastern European states are strong Atlanticists, they should not be forced into the position of choosing between NATO and the EU. Differences should be discussed and overcome, not exploited by individual leaders for short term political gains.

Rather than encouraging transatlantic competition for global influence, EU and NATO officials should seek to define a new partnership designed to address future security challenges. Even without the military prowess of the United States, these allies can contribute to the creation of a peaceful international order. Recent operations in the Balkans, Afghanistan and Iraq have demonstrated the exploding demand for both military and civilian functions related to security and reconstruction assistance. Many European states and the EU have developed capabilities that can be employed during this phase of an operation. NATO Spokesman Jamie Shea envisions a process through which "NATO and the EU would gradually merge almost into twin sister institutions, in much the same way that we consider the World Bank and the International Monetary Fund as twin institutions, having nonetheless each a specialized role but with a large degree of overlap in a common policy." 15 A partnership between NATO and the EU seems appropriate based on the relative strengths of each regime.

NATO serves important functions related to the development and employment of military forces, while the EU performs a number of non-military functions that are

\footnotetext{
${ }^{15}$ NATO Office of Information and Press, "Video Lecture: NATO-EU Relations, February 12, 2004," http://www.nato.int/docu/speech/2004/s040210a.htm.
} 
important to facilitating international cooperation. The EU provides a body of common law that reduces the differences among member states, thus eliminating potential sources of conflict. The economic policies of the EU increase the interdependence of member states while making them more competitive in a global marketplace. The EU has overseen civilian policing and judicial measures that have complemented NATO's military capabilities during recent peacekeeping missions in Bosnia-Herzegovina, Macedonia, and elsewhere. The EU has made important contributions to the GWOT by helping to identify and restrict source of funding to international terrorist groups and to coordinate policing activities within Europe. The EU has improved the cooperation among European court systems and police forces through its Eurojust and Europol programs. Recent initiatives such as adopting a common European arrest warrant, and cracking down on financial crimes such as money laundering have contributed greatly to global counter-terrorism efforts. As the EU develops new capabilities related to security and defense, these initiatives should be coordinated with NATO to avoid duplication and ensure compatibility with existing standards and doctrine. The well-orchestrated evolution of both NATO and the EU offers the greatest hope for establishing a foundation to encourage stability and peace within Europe that can be spread to other regions.

In addition to reaching out to other international security regimes, NATO leaders should increase their interaction with democratic states located well outside its traditional European area of operations. Post-Cold War initiatives such as the organization of the North Atlantic Cooperation Council (NACC) and Partnership for Peace (PfP) were a key part of NATO's practice of collective security. These efforts contributed to improved relations among former adversaries and helped sustain a dialogue that paved the way for 
two rounds of expansion and the addition of ten new member states. While these initiatives have thus far been limited to European and Central Asian states, there is an opportunity to expand them to other regions. NATO's further embrace of a global collective security mission justifies a truly global membership. Australia and Japan have consistently expressed a commitment to the same liberal democratic values that form the basis of the transatlantic alliance and their contributions to the coalitions conducting the GWOT clearly justify their consideration for membership. Other democratic states such as India, South Africa, South Korea and Israel have capabilities that would be invaluable to future NATO operations in the Middle East, Asia, and Africa. The expansion of the Alliance outside of Europe can help NATO overcome the shortcomings resulting from the limited geographic reach of many European allies. When combined with internal reforms giving the NAC the ability to direct collective action with less than full unanimity, NATO could increase its influence in world affairs while working to expand a peaceful, liberal order to more volatile regions such as the Middle East and Africa.

An alliance that is more active in global affairs can be somewhat self-sustaining by generating more interest in frequent and meaningful combined operations. Krebs argues that participation in combined operations is crucial to sustaining alliance cohesion and encourages further cooperation. He notes, "Participation in alliance functions generates increasing knowledge of and trust in emerging motives, decreasing concerns of relative gains and perceptions of intra-alliance threat...Joint force structures and planning reshape each member's military posture to reflect alliance interests, reducing the fear of attack and obviating security dilemma dynamics. NATO diplomats that interact regularly with their Allied colleagues are socialized into a shared culture, transcending 
their national interest. These diplomats are able to directly and indirectly shape their states preferences accordingly." 16 Although NATO has carried out a number of supporting missions associated with the GWOT, there has been a division between American-led coalition operations and operations under NATO command. United States forces have dominated coalition operations while making up only a small portion of the forces participating in NATO operations in Afghanistan and the Balkans. This division of responsibilities is preventing NATO officials from working through the differences that can lead to greater confidence and trust among member states. If American leaders expect NATO to play a greater role in future out-of-area crises, the United States must agree to increase the Alliance's role in ongoing stabilization and reconstruction operations. American leaders must accept the principle that short-term compromises and constraints may encourage the long-term benefits of a more multilateral approach to outof-area operations.

One immediate way in which NATO leaders can assume a larger role in the GWOT is by reexamining the division of responsibilities in Afghanistan. The decision of European member states to increase their troop deployments to Afghanistan is a positive step, but should be accompanied by further integration with ongoing counter-terrorism operations. The expansion of ISAF to some 16,000 troops demonstrates the continued willingness of European governments to bear the expense and risk of global peacekeeping deployments. However, these leaders are reluctant to commit to more direct participation in offensive counter-terrorism operations, which prevents NATO

\footnotetext{
${ }^{16}$ Ronald Krebs, "Perverse Institutionalism: NATO and the Greco-Turkish Conflict" International Organization 53, no. 2 (Spring 1999): 351.
} 
forces from assuming all of the responsibilities of the American-led coalition still operating in southern Afghanistan. The merger of ongoing operations in Afghanistan would demonstrate a renewed commitment to collective security involving more extensive consultations and an opportunity to improve transatlantic relations. This merger could encourage more equitable American participation in NATO-led operations and present opportunities to resolve lingering interoperability and command issues. NATO Secretary General Jaap de Hoop Scheffer recently expressed his support for combining the two Afghanistan missions, proclaiming "NATO needs one set of rules of engagement in Afghanistan." 17 If executed along with a renewed commitment to collective security on the part of member states, this initiative may become an important step to reinstituting "one set of rules of engagement" in other regions.

NATO leaders should also strive to obtain a greater role for the Alliance in peacekeeping and reconstruction efforts in Iraq. The experience of the United States in Iraq has demonstrated the high cost and risk associated with its refusal to transfer any significant degree of control to NATO or any other international organization. Despite earlier disagreements over the threat posed by Iraq's alleged links to terrorist groups and development of WMD, NATO member states all share an interest in the successful creation of a democratic government in Iraq. Insurgent forces opposing this process have clear ties to Al Qaeda and other international terrorist groups and are employing methods that violate the most fundamental principles of international law. Neither the United States nor its European allies want to see Iraq decline into anarchy or come under the

\footnotetext{
${ }^{17}$ Carlotta Gall, "NATO to Expand Force and Task in Afghanistan," The New York Times, October 7, 2005.
} 
control of these groups. A lasting peace in Iraq is contingent upon the ability of a responsible Iraqi government to gain control of the country and provide adequate security along with other essential services. As demonstrated by the past decade of reconstruction and reform in the Balkans, international economic and diplomatic initiatives can do much to bring this about. Divisions within NATO have prevented a similar commitment to improving the conditions in both Afghanistan and Iraq, and member states need to consider the potential impacts to their own security. Europe can contribute a great deal to the process of reconstruction and stabilization, and a reinvigorated NATO is in many ways the most suitable forum for this effort.

A meaningful and focused discussion of the benefits to be obtained through NATO's increased contributions to operations in Afghanistan and Iraq should be just one part of an effort to increase the current level of dialogue within the Alliance. While differences may persist regarding views on the use of force and the relationship between national sovereignty and international law, these differences should not prevent pressing global issues from being discussed within the NAC. During at February 2005 security conference in Munich, German Chancellor Gerhard Schroeder remarked that NATO was "no longer the primary venue where transatlantic partners discuss and coordinate strategies." ${ }^{18}$ He pointed out that the NAC had failed to address such issues as preventing Iran from acquiring nuclear weapons or the EU's interest in lifting the post-Tiananmen arms embargo on China. These and other security challenges have important

\footnotetext{
${ }^{18}$ German Embassy to the United Kingdom, "Speech by Federal Chancellor Gerhard Schröder at the opening of the 41 st Munich Conference on Security Policy, February 12, 2005," http://www.germanembassy.org.uk/speech_by_federal_chancellor_gl.html.
} 
implications for all members of the Alliance and justify a more thorough review within the NAC.

NATO should strive to regain its status as the primary forum for a transatlantic dialogue regarding global security issues. NATO is the only international organization that brings leaders from North America and Europe together to consult on strategic issues and take collective action through an integrated military structure. NATO's current Secretary General, Jaap de Hoop Scheffer has recently called for a "repoliticization" of NATO, noting that "military capabilities are only one part of transformation. They will be worthless if allies cannot agree on how, when and where to use them."19 Lithuania's Minister of National Defense, Gediminas Kirkilas, supports this request, stating "We believe that military transformation can be enhanced by NATO's political transformation, that political dialogue on strategic questions will bring us closer to shared perceptions, which are fundamental for building consensus and a sense of common principles." 20 Updating NATO's Strategic Concept could serve as a vehicle for encouraging a more meaningful dialogue regarding the Alliance's future role. NATO's Strategic Concept has not been updated since 1999, well before the outbreak of the GWOT and the debate over the American strategy of preemption. The current Strategic Concept acknowledges the threats posed by international terrorism and the proliferation of WMD, but gives little concrete guidance to NATO's Military Committee or other subordinate bodies. Among

\footnotetext{
${ }^{19}$ NATO Office of Information and Press "Address by Secretary General, Jaap de Hoop Scheffer 'Transforming NATO - A Political and Military Challenge, April 14, 2005," http://www.nato.int/docu/speech/2005/s050414a.htm.

${ }^{20}$ NATO Office of Information and Press. “Address by H.E. Mr. Gediminas Kirkilas Minister of National Defence of Lithuania on National Approaches to NATO Transformation at the NATO Annual Conference. April 14, 2005," http://www.nato.int/docu/speech/2005/s050414b.htm
} 
the revision to the Strategic Concept, there needs to be a call for in-depth consultations aimed at resolving the differences that lead to foreign policy conflicts. A more meaningful role for NATO's political forums would likely mean more frequent and longer meetings among NATO heads of state and defense ministers, but could result in greater unity and a more thorough understanding of each others interests and policy positions.

Despite the well-publicized differences that have emerged in the recent past, fundamental economic, military, and social links continue to exist between the United States and its NATO allies that offer great promise for a reinvigoration of the Alliance. According to James Cloos, the Director of Transatlantic Relations for the EU Council, "Economic interdependence between the United States and Europe is absolutely staggering. Mutual investment is $\$ 2.8$ trillion. Mutual trade is $\$ 550$ billion...Investment of the United States in Holland alone is ten times U.S. investment in China." ${ }^{21}$ NATO member states are in full agreement regarding fundamental principles such as the importance of democratic governance, free trade, and respect for human rights. NATO has struggled throughout its history with questions of grand strategy, interoperability and burden-sharing, and yet the Alliance has continued to thrive. NATO remains unique among existing international regimes in its ability to conduct combined military interventions under a wide range of conditions and has demonstrated the ability to successfully accept new roles and responsibilities. By pursuing reforms attentive to the factors identified throughout this study, NATO leaders can build upon the long tradition

\footnotetext{
${ }^{21}$ NATO Office of Information and Press, "NATO Stopwatch: The Transatlantic Link, May 17, 2005," http://www.nato.int/docu/speech/2005/s050517a.htm.
} 
of transatlantic cooperation that has made this alliance among the most successful in history and someday bring the rhetoric of collective security into reality.

\section{Recommendations for further research}

Although this research has been limited to the behavior of the transatlantic allies participating in NATO, these findings support some speculation regarding the behavior of states toward international regimes in general. The approaches to regime analysis that are utilized throughout this study can and should be applied to other international regimes. Future research could be undertaken to demonstrate the relevance of the factors of hegemonic leadership, access to relevant capabilities, and a sense of community to other international regimes, whether they deal with issues of security, economics, or other social phenomena. It is also important to note that every international regime coexists and interacts with others. Exploring the linkages between these regimes and the resulting process of regime change offer new opportunities for research. These findings may be generalized to other instances of international cooperation to gain a better understanding of the conditions that must be fulfilled to enable an existing regime to be maintained or to allow new regimes to be adopted.

Future research should also look at other emerging opportunities for collective action in response to out-of-area security challenges on the part of NATO member states. This research may confirm the importance of the factors identified in this dissertation as well as identifying additional factors for consideration. Transatlantic efforts to resolve the chronic Israeli-Palestinian conflict will likely present an opportunity for NATO to practice collective security outside of Europe. While the Israeli government's 2005 withdrawal from Gaza generated increased optimism, the level of support for Hamas in 
recent Palestinian parliamentary elections demonstrates the lingering distrust that threatens to limit further progress toward a peace accord. Formal recognition of Israel and the peaceful coexistence of both communities may eventually be negotiated in exchange for Israel's withdrawal back to its pre-1967 borders, but much work remains to bring this about. NATO member states recognize the need to coordinate their efforts to encourage a settlement of these issues and coordinate the military, diplomatic, and economic efforts necessary to a peaceful settlement. One analyst notes, "An 'honest broker' is needed, trusted by both sides, which can help negotiate and then enforce a sophisticated security package. The United States cannot do this, nor can Europe, as neither is seen as impartial. However far-fetched this might seem at the moment, NATO is probably the only institution that could tackle this problem in the next few years." ${ }^{22}$ If requested, NATO forces could be organized to monitor the terms of a future IsraeliPalestinian peace accord and to aid its enforcement. The role of NATO and other international security regimes is a potentially valuable research topic as the United States and its European allies continue to seek the resolution of remaining disagreements and promote stability throughout this troubled region.

Another opportunity for the United States and its European allies to employ international security regimes in response to an emerging threat is likely to come from Iran's resumption of uranium enrichment activities following a two year suspension. The Iranian government continues to oppose American and European influence in the region and exploits its long-standing ties with international terrorist groups to that end. After

\footnotetext{
${ }^{22}$ Donnelly, Chris, "Building a NATO Partnership for the Greater Middle East," NATO Review 52, no. 1 (Spring 2004) http://www.nato.int/docu/review/2004/issue l/english/art3.html.
} 
remaining conspicuously absent from negotiations aimed at convincing the Iranian government to voluntarily limit its nuclear research, American officials have recently joined representatives from Germany, France and Great Britain in calling for stronger penalties against Iran. The United Nations Security Council is likely to consider ordering sanctions in addition to those already imposed by the United States. While NATO's role in this crisis has yet to be determined, research examining both the incentives and obstacles to collective action will improve our understanding of the inclinations of member states within such a regime and add valuable insights to those emerging from an examination of NATO's evolution to date. 


\section{$\underline{\text { Books }}$}

Assenova, Margarita. The Debate on NATO's Evolution: A Report of the CSIS Eastern Europe Project. Washington DC: Center for Strategic and International Studies, 2003.

Baldwin, David, ed. Neorealism and Neoliberalism: The Contemporary Debate. New York: Columbia University Press, 1989.

Barry, Charles, ed. Reforging the Trans-Atlantic Relationship. Washington, DC: National Defense University Press, 1996).

Bebler, Anton, ed. The Challenge Of NATO Enlargement. Westport, CT: Praeger, 1999).

Bensahel, Nora. The Counterterror Coalitions: Cooperation with Europe, NATO, and the European Union. Santa Monica, CA: RAND, 2003.

Bentham, Jeremy. An Introduction to the Principles of Morals and Legislation (1781). Reprinted in An Introduction to the Principles of Morals and Legislation. Indianapolis, IN: Hackett Publishing, 1988.

Best, Richard. Cooperation With Like-Minded Peoples: British Influences On American Security Policy, 1945-1949. New York: Greenwood Press, 1986.

Bohlen, Charles. The Transformation Of American Foreign Policy. New York: Norton Press, 1969.

Booth, Ken and Steve Smith, eds. International Relations Theory Today. Cambridge: Polity Press: 1995.

Boyne, Walter. Operation Iraqi Freedom: What Went Right, What Went Wrong, and Why. New York: Forge Books, 2003.

Brown, Michael, Sean Lynn-Jones, and Steven Miller, eds. The Perils of Anarchy: Contemporary Realism and International Security. Cambridge, MA: MIT Press, 1995.

Brown, Michael. Theories of War and Peace. Cambridge, MA: MIT Press, 1999.

Buchan, Alistair. NATO in the 1960s. London: Wiedenfeld and Nicolson, 1960. 
Buzan, Barry. People States and Fear: An Agenda for International Security Studies in a Post-Cold War Era, $2^{\text {nd }}$ Edition. Boulder, CO: Lynne Reinner, 1991).

Buzan, Barry, Ole Waever, and Jaap de Wilde. Security: A New Framework for Analysis, Analysis. Boulder, CO: Lynne Reinner Publishers, 1998.

Buzan, Barry and Ole Waever. Regions and Powers: The Structure of International Security. Cambridge: Cambridge University Press, 2003.

Carr, E. H. The Twenty Years ' Crisis, 1919-1939: An Introduction to the Study of International Relations. New York: Macmillan Press, 1946.

Clark, Wesley. Waging Modern War. New York: Public Affairs, 2001.

Claude, Inis. Power and International Relations. New York: Random House, 1962.

Claude, Inis. Swords into Plowshares. New York: Random House, 1971.

Cook, Don. Forging The Alliance: NATO, 1945-1950. London: Secker \& Warburg, 1989.

Cordesman, Andrew. The Lessons and Non-Lessons of The Air And Missile Campaign In Kosovo. Westport, CT: Praeger/Greenwood, 2001.

Crawford, Beverly, ed. The Future of European Security. Berkeley, CA: University of California: 1992.

Deutsch, Karl, Sidney Burrell, Robert Kann, Maurice Lee, Martin Lichterman, Raymond Lindgren, Francis Loewenheim, Richard Van Wagenen. Political Community and the North Atlantic Area: International Organization in the Light of Historical Experience (Princeton: Princeton University Press, 1957.

Deutsch, Karl. The Analysis of International Relations. Englewood Cliffs, NJ: Prentice Hall, 1968.

Donelan, Michael. Elements of International Political Theory. Oxford: Oxford University Press.

Downs, George, ed. Collective Security After the Cold War. Ann Arbor MI: University of Michigan Press, 1993.

Doyle, Michael. Ways of War and Peace, (New York: W.W. Norton, 1997.

Eden, Douglas. Europe and the Atlantic Relationship: Issues of Identity, Security and Power. New York: Palgrave Macmillan, 2000. 
Efinger, Manfred, Volker Rittberger and Michael Zürn. International Regimes in EastWest Relations. London: Pinter Press, 1988.

Flynn, Gregory. French NATO Policy: The Next Five Years (Washington, D.C.: RAND, 1989.

Forster, Anthony, Timothy Edmunds and Andrew Cottey. The Challenge of Military Reform in Post-Communist Europe: Building Professional Armed Forces. London: Palgrave Macmillan, 2002.

Fursdon, Edward. The European Defense Community: A History. London: Macmillan Press, 1980.

Gaddis, John Lewis. We Now Know: Rethinking Cold War History. New York: Oxford University Press, 1990.

Gallis, Paul. NATO Enlargement: Congressional Research Service Report 21055. Washington D.C.: Congressional Research Service, 2003.

George, Alexander, Philip Farley and Alexander Dallin, eds. U.S.-Soviet Security Cooperation: Achievements, Failures, Lessons. New York: Oxford University Press: 1998.

Gilpin, Robert. War and Change in World Politics. Cambridge: Cambridge University Press, 1981.

Goldstein, Morris. The Global Effects of Fund-Supported Adjustment Programs: IMF Occasional Paper 42 (Washington, D.C.: International Monetary Fund, 1986).

Gordon, Philip and Jeremy Shapiro. Allies at War: America, Europe and the Crisis in Iraq. New York:McGraw-Hill, 2004.

Gress, David. From Plato to NATO: The Idea Of The West And Its Opponents. New York: The Free Press, 1998.

Grieco, Joseph. Cooperation Among Nations: Europe, America, and NonTariff Barriers to Trade. Ithaca, NY: Cornell University Press, 1990.

Guertner, Gary. Collective Security in Europe and Asia. Carlisle Barracks, PA: Strategic Studies Institute Press, 1992.

Gulick, Edward. Europe's Classical Balance of Power. Ithaca, NY: Cornell University Press, 1955. 
Haas, Ernst. Beyond the Nation-State: Functionalism and International Organization. Stanford, CA: Stanford University Press, 1964.

Hampton, Mary. The Wilsonian Impulse: U.S. Foreign Policy, the Alliance, and German Unification. Westport, CT: Praeger Press, 1996.

Lansford, Tom and Robert Watson, eds. America's War on Terror. Aldershot: Ashgate, 2002.

Hodge, Carl, ed. NATO for a New Century: Atlanticism and European Security. Westport, CT: Praeger, 2002

Hodge, Carl. Atlanticism for a New Century: The Rise, Triumph, and Decline of NATO. Upper Saddle River, NJ: Prentice Hall, 2005.

Hollad, Martin, ed. Common Foreign And Security Policy: The Record And Reform. London: Cassell, 1992).

Hunt, Kenneth. NATO Without France: The Military Implications. London: Institute For Strategic Studies, 1966.

Hurrell, Andrew and Benedict Kingsbury, eds. The International Politics of the Environment. New York, Oxford University Press, 1992.

Ikenberry, John. After Victory: Institutions, Strategic Restraint, and the Rebuilding of Order after Major Wars. Princeton: Princeton University Press, 2001.

Ismay, Hastings. NATO: The First Five Years, 1949-1954. Utrecht, NE: BoschUtrecht Press, 1955.

Jackson, Robert. The Global Covenant: Human Conduct in World Affairs. New York: Oxford University Press, 2000.

Jacobson, Harold. Networks of Interdependence: International Organizations and the Global Political System. New York: Alfred Knopf Press, 1984.

Joffe, Joseph. The Limited Partnership: Europe, the United States, and the Burdens of Alliance. Cambridge, MA: Ballinger Publishing Co., 1987.

Kagan, Robert. Of Paradise and Power: America and Europe in the New World Order. New York: Alfred A. Knopf, 2003.

Kant, Immanuel. Eternal Peace and Other International Essays (1795). Reprinted in Eternal Peace and Other International Essays. Boston: The World Peace Foundation, 1914. 
Kaplan, Lawrence, ed. American Historians And The Atlantic Alliance. Kent, OH: Kent State University Press, 1991.

Katzenstein, Peter, ed. The Culture of National Security: Norms and Identity in World Politics. New York: Columbia University Press, 1996.

Kay, Sean. NATO And The Future Of European Security. Lanham, MD: Rowman \& Littlefield Publishers, 1998.

Keegan, John. The Iraq War. New York: Alfred A. Knopf: 2004.

Kennan, George. At A Century's Ending: Reflections, 1982-1995. New York: W.W. Norton, 1996.

Keohane, Robert and Joseph Nye. Power and Independence: World Politics in Transition. Boston: Little Brown, 1977.

Keohane, Robert. After Hegemony: Cooperation and Discord in the World Political Economy. Princeton: Princeton University Press, 1984.

Keohane, Robert, ed. International Institutions and State Power: Essays in International Relations Theory. Boulder, CO: Westview Press, 1989.

Keohane, Robert, Joseph Nye, and Stanley Hoffman, eds. After the Cold War:

International Institutions and State Strategies in Europe, 1989-1991. Cambridge, MA: Harvard University Press, 1993.

Kindleberger, Charles. The World in Depression: 1929-1939. Berkeley: University of California Press, 1973.

Kissinger, Henry. White House Years. Boston: Little, Brown, 1979.

Kissinger, Henry. Diplomacy. New York: Simon and Shuster, 1994.

Krasner, Stephen, ed. International Regimes. Ithaca, NY: Cornell University Press, 1983.

Kugler, Richard, Commitment to Purpose: How Alliance Partnership Won the Cold War. Santa Monica, CA: RAND Corporation, 1993.

Kupchan, Charles, Emanuel Adler, Jean-Marc Coicaud and Yuen Foong Khong. Power in Transition: The Peaceful Change of International Order. New York: United Nations University Press, 2001. 
Lansford, Tom. All For One: Terrorism, NATO and the United States. Burlington, VT: Ashgate, 2002.

Lansford, Tom. A Bitter Harvest: U.S. Foreign Policy and Afghanistan. Burlington, VT: Ashgate, 2003.

Larrabee, Stephen. NATO's Eastern Agenda in a New Strategic Era. Santa Monica, CA: RAND, 2003.

Lebow, Ned. The Tragic Vision of Politics: Ethics, Interests and Orders. Cambridge: Cambridge University Press, 2003.

Leonard, Mark. Making Europe Popular: The Search for a European Identity. London: Demos, 1998.

Linberg, Tod, ed. Beyond Paradise and Power: Europe, America and the Future of a Troubled Partnership. New York: Routledge, 2005.

Mangone, Gerard. A Short History of International Organization. New York: McGraw-Hill, Inc, 1954.

McSweeney, Bill. Security, Identity and Interests: A Sociology of International Relations. Cambridge: Cambridge University, 1999.

Mearsheimer, John. The Tragedy of Great Power Politics. New York: Alfred A. Knopf Press, 1948.

Mitrany, David. A Working Peace System (Chicago, Quadrangle Press, 1943.

Moens, Alexander, Lenard Cohen and Allen Sens, eds. NATO and European Security: Alliance Politics from the End of the Cold War to the Age of Terrorism. Westport, CT: Praeger, 2003.

Morgenthau, Hans. Scientific Man Versus Power Politics. Chicago: Chicago University Press, 1946.

Morgenthau, Hans. Politics Among Nations: The Struggle for Power and Peace, $5^{\text {th }}$ edition. New York: Alfred A. Knopf, 1978.

Nugent, Neill. The Government And Politics Of The European Political Community. Durham, NC: Duke University Press, 1989.

O'Brien, Patrick and Armand Clesse, eds. Two Hegemonies: Britain 1846-1914 and the United States 1941-2001. Aldershot: Ashgate Publishing, Ltd., 2002. 
Ochmanek, David. NATO's Future: Implications for U.S. Military Capabilities and Posture. Washington DC: RAND, 2000.

O'Hanlon, Michael, Susan Rice and James Steinberg, The New National Security Strategy and Preemption: Policy Brief \#113. Washington D.C.: Brookings Institution, 2002.

O'Hanlon, Michael. Expanding Global Military Capacity for Humanitarian Intervention. Washington DC: Brookings Institution Press, 2003.

Olson, Mancur. The Logic of Collective Action: Public Goods and the Theory of Groups. Cambridge, MA: Harvard University Press, 1965.

Onuf, Nicholas. World of Our Making Rules and Rule in Social Theory and International Relations. Colombia, SC: University of South Carolina Press, 1989.

Owen, Robert, ed. Deliberate Force: A Case Study In Effective Air Campaigning. Montgomery, AL: Air University Press, 2000.

Pedersen, Thomas. Germany, France and the Integration of Europe: A Realist Interpretation. London: Pinter Press, 1998.

Peters, John, Stuart Johnson, Nora Bensahel, Timothy Liston, Traci Williams. European Contributions to Operation Allied Force: Implications for Transatlantic Cooperation. Santa Monica, CA: RAND, 2001.

Pollack, Kenneth. The Threatening Storm: The United States and Iraq: The Crisis, the Strategy, and the Prospects After Saddam. New York: Random House, 2002.

Preussen, Ronald. John Foster Dulles: The Road To Power. New York: Free Press, 1982.

Rittberger, Volker, ed. Regime Theory and International Relations. Oxford: Clarendon Press, 1990.

Rousseau, Jean Jacques. Discourse on the Origin and Basis of Inequality Among Men (1755). Reprinted in The Social Contract and the First and Second Discourse. New Haven, CT: Yale University Press, 2002.

Saint-Pierre, Abbe. A Project for Perpetual Peace (1713). Reprinted in Steven Cooper, ed. Peace Projects of the Seventeenth Century. New York: Garland Press, 1974.

Sandler, Todd and Keith Hartley, The Political Economy of NATO. New York: Cambridge University Press, 1999. 
Schwartz, Thomas. America's Germany: John J. McCloy and the Federal Republic of Germany. Cambridge: Harvard University Press, 1991.

Shawcross, William. Allies: U.S., Britain, and Europe, and the War in Iraq. New York: Public Affairs, 2003.

Snyder, Jack and Robert Jervis, eds. Coping with Complexity in the International System. Boulder, CO: Westview Press, 1993.

Spiegeleire, Stephan, Erik Van De Linde, Kevin O’Brien, Gustav Lindstrom, Mikko Veyrynen, Han De Vries. Quick Scan of Post 9/11 National Counter-Terrorism Policymaking and Implementation in Selected European Countries: Research Project for the Netherlands Ministry of Justice. Santa Monica: RAND, 2002.

Staerck, Andre De. NATO's Anxious Birth, New York: St. Martin's Press, 1985.

Thatcher, Margaret. The Downing Street Years. New York: Harper Collins, 1993.

Thody, Philip. An Historical Introduction to the European Union. London and New York: Routledge, 1997.

Truman, Harry. Memoirs: Volume II: Years of Trial and Hope. Garden City, NY: Doubleday \& Company, 1955.

Viotti, Paul and Mark Kauppi, eds. International Relations Theory: Realism, Pluralism, Globalism. New York: MacMillan, 1993.

Waltz, Kenneth. Theory of International Politics. Reading, MA: Addison-Wesley Press, 1979.

Wendt, Alexander. Social Theory of International Politics. Cambridge: Cambridge University, 1999.

Wight, Martin. Systems of States, London: Leiscester University Press, 1977.

Wijk, Ron De. NATO on the Brink of the New Millennium: the Battle for Consensus. London: Brassey Press, 1997.

Williams, Michael, ed. International Relations Theory and the Politics of European Integration: Power Security and Community. London: Routledge, 2000.

Williams, Phil, Donald Goldstein, and Jay Shafritz, eds. Classic Readings of International Relations. Fort Worth, TX: Harcourt Brace College Press, 1994. 
Woods, Ngaire, ed. Explaining International Relations since 1945. Oxford: Oxford University Press, 1996.

Woodward, Bob. Bush at War. New York: Simon and Shuster, 2002.

Wright, Quincy. Tbe Study of International Relations. New York: Appleton-CenturyCrofts, 1955.

Yost, David. NATO Transformed - The Alliance's New Roles in International Security. Washington D.C.: United States Institute of Peace Press, 1998.

Young, Owen. Compliance and Public Authority: A Theory with International Applications. Baltimore, MD: Johns Hopkins Press, 1989.

$\underline{\text { Journals }}$

Allin, Dana. "Debating Intervention." NATO Review no. 4 (Winter 2002): 2-4.

Andreani, Gilles. "The Disarry of U.S. Non-Proliferation Policy." Survival 41 (Winter 1999-2000): 42-61.

Andreani, Gilles. "Why Institutions Matter." Survival 42 no. 2 (Summer 2000): 81-95.

Appathurai, James. "Closing the Capabilities Gap." NATO Review 50 no. 3 (Fall 2002): $2-4$.

Asmus, Ronald. “Great Expectations.” NATO Review 51, no. 2 (Summer 2003): 28-33.

Barry, Charles. "NATO's Combined Joint Task Forces in Theory and. Practice." Survival 36, no. 3 (Spring 1996): 81-97.

Bennett, Andrew and Joseph Lepgold. "Reinventing Collective Security After the Cold War and Gulf Conflict." Political Science Quarterly 108, no. 2 (September 1993): 213-37.

Bennett, Christopher. "Combatting Terrorism.” NATO Review 51, no 1 (Spring 2003): $5-7$.

Boyer, Yves and Burkard Schmidt. "Should and Can Europe Bridge the Capabilities Gap?" NATO Review 50, no. 3 (Fall 2002): 12-16.

Buckley, Edgar. "Attainable Targets.” NATO Review 50, no. 3 (Fall 2002): 5-6. 
Christenson, Thomas and Jack Snyder, "Chain Gangs and Passed Bucks: Predicting Alliance Behavior in Multipolarity." International Organization 44, no. 2 (Spring 1990): 136-168

Cilluffo, Frank and Daniel Rankin, "Fighting terrorism." NATO Review 49, no. 4 (Winter 2001): 12-15.

Claude, Inis. "The Collectivist Theme in International Relations." International Journal, 24 (1969): 655-95.

Claude, Inis. "The Balance of Power Revisited." Review of International Studies 15 (1989): 77-85.

Cohen, Leonard and Alexander Moens, "Learning the Lessons of UNPROFOR: Canadian Peacekeeping in the Former Yugoslavia." Canadian Foreign Policy 6, no. 2 (1999): 85-101.

Cox, Robert. "Social Forces, States and World Orders." Millennium: Journal of International Studies 10 no 2, (1981): 126-55.

Daalder, Ivo and James Goldgeier, "Putting Europe First." Survival 43, no. 1 (Spring 2001): 71-91.

Doyle, Michael. "Liberalism and World Politics." American Political Science Review 80, no. 4 (December 1986): 1151-69.

Eyal, Jonathan. "NATO's Enlargement: Anatomy of a Decision." Journal of International Affairs 73, no. 4 (October 1997): 695-719.

Everts, Steven and Gary Schmidt, "Is Military Power Still the Key to International Security?" NATO Review 50, no. 4 (Winter 2002): 17-22.

Furniss, Edgar. "De Gualle's France and NATO: An Interpretation.” International Organization 15, no. 2 (Summer 1961): 349-65..

Gordon, Philip. “NATO After 11 September.” Survival 42, no. 4 (Winter 2001-2002): 97-128.

Greenwood, Frederic. "PRTs: Military Personnel Provide Unique Reconstruction Capabilities." CENTCOM Bulletin no. 5 (May 2003): 6-7.

Grieco, Joseph. "Anarchy and the Limits of Cooperation: A Realist Critique of the Newest Liberal Institutionalism.” International Organization 42, no. 3 (Summer 1988): 485-507. 
Haggard, Stephen and Beth Simmons. "Theories of International Regimes." International Organization 41, no 3 (Summer 1987): 491-518.

Hamilton, Daniel and Tim Garden. "Should NATO's New Function be CounterTerrorism?" NATO Review 50, no. 2 (Summer 2002): 16-20.

Harries, Owen. "The Collapse of the 'West'." Foreign Affairs 72 (September/October 1993): 41-53

Hunter, Robert. "Enlargement: Part of a Strategy for Projecting Stability into Central Europe." NATO Review 43. no.3 (May 1995): 3-8.

Huntington, Samuel. "Why International Primacy Matters." International Security 17 no. 4 (Spring 1993): 68-83.

Ikenberry, John and Charles Kupchan, "Socialization and Hegemonic Power." International Organization 44, no. 3 (Summer 1990): 286-316.

“Interview with General James L. Jones, SACUER.” NATO Review 51, no. 1 (Spring 2003): 22-4.

"Interview with General William F. Kernan, Military Modernizer." NATO Review 50, no. 3 (Fall 2002): 21-3.

Irondelle, Bastien. "Europeanization without the European Union? French military reforms 1991-96." Journal of European Public Policy 10, no 2 (April 2003): 20826.

"ISAF, Under the Leadership of Turkey." CENTCOM Coalition Bulletin, no. 3 (January 2003): 9-10.

Jakobson, Max. "Collective Security in Europe Today." Washington Quarterly 18, no. 2 (Spring 1995): 59-70.

Joffe, Josef. "Collective Security and the Future of Europe: Failed Dreams and Dead Ends." Survival (Spring 1992): 36-50.

Kagan, Robert. “The Benevolent Empire.” Foreign Policy 111 (Summer 1998): 24-35.

Kaufman, Stuart. "The Fragmentation and Consolidation of the International System." International Organization 51, no. 2 (Spring 1997): 173-208.

Keohane, Robert. "International Institutions: Two Approaches." International Studies Quarterly 32, no. 4 (December 1988): 379-96. 
Keohane, Robert and Lisa Martin. "The Promise of Institutionalist Theory." International Security 20 no. 1 (Summer 1995): 39-51.

Koslowski, Rey and Friedrich Kratochwil. "Understanding Change in International Politics: The Soviet Empire's Demise and the International System." International Organization 48, no. 2 (Spring 1994): 215-248.

Krause, Joachim. "Proliferation Risks and their Strategic Relevance: What Role for NATO?" Survival 37, no. 2 (Summer 1995): 135-48.

Krebs, Ronald. "Perverse Institutionalism: NATO and the Greco-Turkish Conflict." International Organization 53, no. 2 (Spring 1999): 343-77.

Kriender, John. “Anticipating Crises.” NATO Review 50, no. 4 (Winter 2002): 14-6.

Kupchan, Charles and Clifford Kupchan, "Concerts, Collective Security, and the Future of Europe.” International Security 16, no 1 (1991): 114-161.

Kupchan, Charles. "Reviving the West." Foreign Affairs 75 no. 3 (May/June 1996): 92-104.

Larrabee, Stephen and Francois Heisbourg, "How Global a Role Can and Should NATO Play?" NATO Review 51, no. 1 (Spring 2003): 13-7.

Legge, Michael. “The Making Of NATO's New Strategy." NATO Review 39, no. 6 (November-December 1991): 9-14.

Lewis, Bernard. "License to Kill: Usama bin Laden's Declaration of Jihad." Foreign Affairs 77, no. 6 (November/December 1998): 9-15.

Mandelbaum, Michael. "Preserving The New Peace: The Case Against NATO Expansion." Foreign Affairs 74, no. 3 (May/June 1996): 9-13.

Manners, Ian and Richard Whitman. "The Difference Engine: Constructing and Representing the International Identity of the European Union." Journal of European Public Policy 10, no. 3 (June 2003):380-404.

Mastanduno, Michael, "Preserving the Unipolar Moment." International Security 21, no. 4 (Spring 1997): 49-88.

McCalla, Robert. "NATO's Persistence After the Cold War." International Organization 50, no. 3 (Summer 1996): 445-475

Mearsheimer, John. "Back to the Future: Instability in Europe After the Cold War." International Security 15, no. 1 (Summer 1990): 5-56. 
Naumann, Klaus. "Crunch Time for the Alliance." NATO Review 50, no. 2 (Summer 2002): 9-12.

Joseph Nye. “The U.S. and Europe: Continental Drift?” International Affairs 76, no. 1 (January 2000): 51-61.

O'Hanlon, Michael. “A Flawed Masterpiece.” Foreign Affairs 81, no. 3 (May-June 2002): 47-63.

Owen, John. "How Liberalism Produces Democratic Peace." International Security 19, no. 2 (Autumn 1994): 87-125.

Parmentier, Guillaume. "Redressing NATO’s Imbalances.” Survival 42, no. 2 (2002): 96-112.

Reiter, Dan. "Why NATO Enlargement Does Not Spread Democracy." International Security 25, no.4 (Spring 2001): 41-67.

Robertson, George. "Investing in Security." NATO Review 50, no. 3 (Fall 2002): 7-8

Robertson, George. "Change and Continuity." NATO Review 51, no 3 (Winter 2003): $2-6$.

Robertson, George. “Transforming NATO,” NATO Review 51, no. 1 (Spring 2003): 24.

Rice, Condoleeza. "Campaign 2000: Promoting the National Interest." Foreign Affairs 79, no. 1, (January/February 2000): 45-62.

Risse, Thomas. "The Euro Between National and European Identity." Journal of European Public Policy 10, no. 4 (August 2003): 487-503.

Rittberger, Volker. "Regime Theory: Findings from the Study of East West Regimes." Cooperation and Conflict, 26 no. 4 (Autumn 1991): 165-83.

Rubenstein, Alvin. "NATO Enlargement vs. American Interests," Orbis 42, no. 1 (Winter 1998): 37-48.

Ruggie, John. "International Regimes, Transactions, and Change: Embedded Liberalism in the Postwar Economic Order." International Organization 36 no. 2 (Spring 1982): 379-415.

Ruggie, John. "Third Try at World Order? America and Multilateralism After the Cold War." Political Science Quarterly 109, no. 3 (Fall 1994): 553-70. 
Ruhe, Volker. "Shaping Euro-Atlantic Policies: A Grand Strategy for a New Era." Survival 35, No. 2 (Summer 1993): 129-37.

Ruiz, Diego. “The Road to Kabul,” NATO Review 51, no. 2 (Summer 2003): 9-12.

Sloan, Stanley. "Crisis Response,” NATO Review 50, no.1 (Spring 2002): 26-8.

Smith, Anthony. "National Identity and the Idea of European Unity." International Affairs 68, no. 1 (1992): 55-76.

Snidal, Duncan. "International Cooperation Among Relative Gain Maximizers." International Studies Quarterly 35 (1991): 387-402.

Snidal, Duncan. "The Limits of Hegemonic Stability Theory." International Organization 39, no. 4 (Autumn 1985): 579-614.

Soros, George. "Can Europe Work? A Plan to Rescue the Union." Foreign Affairs 75 no. 5 (September/October 1996): 8-14.

Stein, Arthur. "Coordination and Collaboration: Regimes in an Anarchic World." International Organization 36, no 2 (Spring 1982): 294-324.

Sundseth, Roar. "The War on Terrorism: A Norwegian's Perspective." CENTCOM Coalition Bulletin, no. 2 (November 2002): 8.

Walt, Stephen, "Why Alliances Endure or Collapse." Survival 39 no. 1 (Spring 1997): 156-179.

Waltz, Kenneth. "Structural Realism After the Cold War." International Security 25 (Summer 2000): 5-41.

Wendt, Alexander. "Collective Identity Formation and the International State." American Political Science Review 88, no. 2. (Summer, 1994): 384-96.

Alexander Wendt, "Anarchy is What States Make of It: The Social Construction of Power Politics," International Organization 46, no. 2 (1992): 391-425.

“X," "The Sources of Soviet Conduct," Foreign Affairs 25 (July, 1947): 566-582.

\section{Magazines}

Bender, Bryan. “U.S. Worried by Coalition 'Technology-Gap'." Jane's Defence Weekly (July 29, 1998): 8-9. 
Goldgeier, James. "NATO Expansion: The Anatomy Of A Decision." The Washington Quarterly 21, no. 1 (Winter 1998): 85-102.

Kitfield, James. "NATO Metamorphosis." National Journal 34, no. 6 (February 9, 2002): 376-380.

Kitfield, James. "Pox Americana?” National Journal 34, (April 6, 2002): 982-7.

Kitfield, James. "U.S. to NATO: Change or Else.” National Journal (October 12, 2002): 2978-9.

Lagon, Mark. "The Illusions of Collective Security." The National Interest 40 (Summer 1995): 50-61.

Mearsheimer, John. "Offensive Realism," University of Chicago Magazine 94 , no 3 (2002): 10-14.

Talbott, Strobe. "Why NATO Should Grow." New York Review of Books 42, no. 13 (August 1995): 27-30.

"The Ageing Alliance," The Economist (October 23, 1999): 10

\section{Newspapers}

Aznar, Jose Maria, Jose-Manuel Durao Barroso, Silvio Berlusconi, Tony Blair, Vaclav Havel, Peter Medgyessy, Leszek Miller, and Anders Fogh Rasmussen. "European Leaders in Support of U.S.” Wall Street Journal, January 30, 2003.

Barrie, Douglas and Jack Hoschouer. "Bundeswehr's Unclear Role Underlies Budget Conflicts." Defense News, August 9, 1999.

Borowiec, Andrew. "Funding Shortage Threatens EU Force." Washington Times, February 16, 2006.

Cavas, Christopher. "Polish Minister, Rumsfeld Discuss NATO Issues," Defense News, December 12, 2005.

Coughlin, Tom. "Nato 'Pacifists' Under Fire As U.S. Begs Help On Terror Front Line." London Sunday Telegraph, September 18, 2005.

Daley, Suzanne. "NATO, Though Supportive, Has Little to Offer Militarily." The New York Times, September 20, 2001.

Dempsey, Judy. "Washington Turns Deaf Ear to Europe's Divided Voices." Financial Times, February 13, 2002. 
Dempsey, Judy and David Cloud. "Europeans Balking At New Afghan Role." International Herald Tribune, September 14, 2005.

DeYoung, Karen. "U.S. Officials Say UN Future at Stake in Vote; Bush Message Is that a War Is Inevitable, Diplomats Say." The Washington Post, February 25, 2003.

Dombey, Daniel and Peter Spiegel. "Concerns In NATO As Troops Prepare For Afghan Mission.” London Financial Times, September 12, 2005.

Drozdiak, William. "U.S. Tepid on European Defense Plan: American Stance Vexed EU Leaders." The Washington Post, March 7, 2000.

Erlanger, Steven. "Yeltsen Basks at Summit; Some Europeans are Cool to the U.S.," The New York Times, May 30, 1997.

“French Dove Turns Hawk on Pullout," New York Post, November 30, 2005.

Gall, Carlotta. "NATO to Expand Force and Task in Afghanistan." The New York Times, October 7, 2005.

Gordon, Michael. "Armies of Europe Failing to Meet Goals, Sapping NATO." The New York Times, June 7, 2001.

Hayes, Stephen. "An Intelligent Democrat." The Weekly Standard, December 15, 2003.

Kaminski, Matthew. "NATO is Unprepared to Fight Terrorism." Wall Street Journal, October 8, 2001.

Kennan, George. “A Fateful Error.” The New York Times, February 7, 1997.

Kissinger, Henry. "Letter to the editor." The Washington Post, July 23, 1997.

Kissinger, Henry. “A Dangerous Divergence.” The Washington Post, December 10, 2002.

Kissinger, Henry. "Role Reversal and Alliance Realities." The Washington Post, February 10, 2003.

Krauthammer, Charles. "The New Unilateralism." The Washington Post, June 8, 2001.

Levitte, Jean-David. “A Warning on Iraq, from a Friend." The New York Times, Februrary 14, 2003. 
Mitchell, Allison. "NATO Debate" From Big Risk to Sure Thing." The New York Times, March 20, 1998.

"NATO Blocked on Iraq Decision." The Washington Post, January 23, 2003.

Preston, Julia and Steven Weisman. "France Offering Plan to Expand Iraq Arms Hunt." The New York Times, February 12, 2003.

Rice, Condoleezza. “Our Coalition.” Wall Street Journal, March 26, 2003.

Richter, Paul. “NATO Balking At Iraq Mission.” Los Angeles Times, May 9, 2004.

Ricks, Thomas. "Allies Step Up Somalia Watch; U.S. Aims to Keep Al Qaeda at Bay." The Washington Post, January 4, 2002.

Rumsfeld, Donald. “We Must Be Patient About Progress In Iraq.” Seattle Times, July 4, 2005.

Sands, David. “Allies See Benefits in Iraq Missions." Washington Times, December 9, 2005.

Scarborough, Rowen. "Clinton First Linked Al Qaeda to Saddam." Washington Times, June 28, 2004.

Scarborough, Rowen. "Rumsfeld Rejects 'Quitting' As 'Exit Strategy' From Iraq." Washington Times, November 20, 2005.

Shishkin, Philip. "NATO's Peacekeeping Problem." Wall Street Journal, August 8, 2005.

Sloan, Stanley. "Give NATO a Combined Task Force Against Terrorism." International Herald Tribune, November 13, 2001.

Smale, Alison. "Iraq May Be Years From Returning To Peak Oil Output, Ex-Minister Says." International Herald Tribune, September 22, 2005.

Suro, Roberto and Thomas Ricks. "Pentagon Acknowledges Kosovo Air War Data Leaked." The Washington Post, March 10, 2000.

"U.S.-led Coalition Shrinks as More Nations Pull Troops." Los Angeles Times, December 28, 2005.

White, Griff. "Reconstruction Costs Unkown.” The Washington Post, May 10, 2005 
Wright, Jonathan. "U.S. outlines Limited Role in Rebuilding." Houston Chronicle, December 7, 2001

\section{Government Documents}

European Union Office of External Relations. Presidency Conclusions, Cologne European Council, June 3-4, 1999. Brussels: European Union, 1999.

National Commission on Terrorism. Countering the Changing Threat of International Terrorism: Report of the National Commission on Terrorism. Washington: GPO, 2000.

NATO Office of Information and Press. NATO Basic Fact Sheet: NATO's Role In Bringing Peace To The Former Yugoslavia, March 1997. Brussels: NATO Office of Information and Press, 1997.

NATO Office of Information and Press. SACEUR, First Annual Report. Brussels: NATO Office of Information and Press, 1951.

NATO Office of Information and Press. NATO Fact Sheet: The Combined and Joint Task Force Concept, August 8, 2000. Brussels: NATO Office of Information and Press, 2000.

U.S. Congressional Budget Office. Paying for Iraq's Reconstruction. Washington D.C.: $\mathrm{CBO}, 2004$.

U.S. Department of State. Secretary of State Strobe Talbott Presentation to the Royal Institute of International Affairs in London, October 7, 1999. Washington D.C.: U.S. Department of State, 1999.

White House Office of Press Secretary. Fact Sheet: Operation Enduring Freedom Overview: Campaign Against Terrorism Results, Period Covered 14-30 September 2001. Washington D.C.: U.S. Department of State, 1999.

White House Office of Press Secretary. The National Security Strategy of the United States of America. Washington D.C.: White House, 2002.

\section{$\underline{\text { Online Journals }}$}

Butler, Nicola. "NATO Ministers Fudge the Essentials." Disarmament Diplomacy 42 (December 1999). http://www.acronym.org.uk/dd/dd42/42nato.htm.

Colston, John. "Marrying Capabilities to Commitments." NATO Review 52, no. 2 (Summer 2004). http://www.nato.int/docu/review/2004/issue2/english/ military.html. 
Dobbins, James. “NATO’s Role in Nation-Building.” NATO Review 53, no. 2

(Summer 2005). http://www.nato.int/docu/review/2005/issue2/english/art 1.html.

Donnelly, Chris. "Building a NATO Partnership for the Greater Middle East." NATO Review 52, no. 1 (Spring 2004). http://www.nato.int/docu/review/2004/issue 1/ english/art3.html.

Elliott, Michael. "The Battle over Peacekeeping: As the fighting in Afghanistan Drags on, American Troops Risk Being Dragged into a Messy Civil War." Time, March 4, 2002. http://www.time.com/time/magazine/ article/0,9171,1001917,00.html

"Exclusive Interview: Conversation with Terror." Time, January 11, 1999. http://www.time.com/time/asia/news/interview/0,9754,174550-2,00.html

Jones, James. "Military Matters: Transforming NATO's Military Structures." NATO Review 52, no. 1 (Spring 2004 ). http://www.nato.int/docu/review/2004/issue 1/ english/military.html

"Old Friends, Best Friends." The Economist, September 13, 2001. http://www. economist.com/printedition/displayStory.cfm?Story_ID=780405.

Ruiz, Diego. "Afghanistan's Transformational Challenge," NATO Review 53, no. 2 (Summer 2005). http://www.nato.int/docu/review/2005/issue2/english/art2.html

\section{$\underline{\text { Online Documents }}$}

Afghan Transitional Government. "Agreement on Provisional Arrangements in Afghanistan Pending the Re-establishment of Permanent Government Institutions, Annex I: International Security Force, December 5, 2001." http://www.afghangovernment.com/AfghanAgreementBonn.htm

Avalon Project at Yale Law School. "Senate Resolution 239, Eightieth Congress, $2^{\text {nd }}$ Session, June, 11, 1948." http://www.Yale.Edu/Lawweb/Avalon/Decade/ Decad040.htm.

BBC News. “Allies and Lies, June 22, 2001.” http://news.bbc.co.uk/1/hi/audiovideo/ programmes/correspondent/1390536.stm

British American Security Information Council. "European Defense: Not more Tanks, More Cops: BASIC Study, November 1999." http://www.basicint.org/ europe/ESDP/1199-not_more_tanks.htm.

Canadian Ministry of National Defense. "Backgrounder: The Canadian Forces' Contribution to the International Campaign Against Terrorism, January 7, 2001.” http://www.forces.gc.ca/site/Newsroom/view_news_e.asp?id=490. 
Canadian Ministry of Foreign Affairs and International Trade. "Backgrounder: Canada's Action Against Terrorism Since September 11, January 3, 2002." http://www.dfait-maeci.gc.ca/anti-terrorism/canadaactions-en.asp.

Embassy of France to United States. "Franco-British Summit Joint Declaration on European Defence, Saint-Malo, December 4, 1998." http://www.infofrance.org/news/statmnts/pr/stmalo.htm.

Embassy of France in the United States. "France's Response to 9/11." http://www.francetourism.com/update_Vigipirate.asp

Embassy of France in the United States. "National Defense Update, 7 April 2005." http://www.ambafrance-us.org/atoz/defense.asp.

European Union Office of External Relations. "Declaration of 9 May 1950." http://europa.eu.int/abc/symbols/9-may/decl_en.htm

European Union Office of External Relations. "Eurostat Statistics in Focus, Economy and finance, no. 4298, June 1998.” http://epp.eurostat.cec.eu.int/portal/4298.

European Union Office of External Relations. "Speech by the Honorable Dimitris Platis at Columbia University, May 15, 2003." http://europa-eu-un.org/articles/hu/ article_2375_hu.htm.

European Union Office of External Relations. "The EU's Relations with Afghanistan." http://europa.eu.int/comm/external_relations/afghanistan/intro/.

European Union Office of External Relations. "The EU's Relations with Iraq." http://europa.eu.int/comm/external_relations/iraq/intro/.

European Union Office of External Relations. "Treaty on European Union." http://europa.eu.int/en/record/mt/top.html.

Fordham University. "Address Before A Joint Session Of Congress, March 12, 1947: The Truman Doctrine." http://www.Fordham.Edu/Halsall/Mod/ 1947TRUMAN.html.

Fordham University. "Speech At The Harvard University Commencement, June 5, 1947." http://www.fordham.edu/halsall/mod/1947marshallplan l.html.

French Mission to United Nations. "Replies by M. Lionel Jospin, Prime Minister, to Questions in the National Assembly, November 6, 2001." http://www. un.int/france/documents_anglais/011106_mae_jospin_asie.htm. 
German Embassy to the United Kingdom. "Speech by Federal Chancellor Gerhard Schröder at the opening of the 41st Munich Conference on Security Policy, February 12, 2005." http://www.german-embassy.org.uk/speech _by_federal_chancellor_g1.html.

German Marshall Fund of the United States. "German Chancellor Stresses Importance of Relationship with United States." http://www.gmfus.org/press/article. $\mathrm{cfm}$ ?id=58.

Global Security. "Operation Enduring Freedom - Order of Battle." http://www.globalsecurity.org/military/ops/enduring-freedom_orbat-01.htm

Leinden University. "History Of European Integration Site: The Pleven Plan." http://www.Eu-History.Leidenuniv.Nl/Index.Php3?M=10\&C=51.

NATO Office of Information and Press. "Text of The North Atlantic Treaty, April 4, 1949." http://www.nato.int/docu/basictxt/treaty.htm.

NATO Office of Information and Press. "Resolution of Association by Other Parties to the North Atlantic Treaty Adopted by the North Atlantic Council, October 22, 1954." http://www.nato.int/docu/basictxt/b541022d.htm.

NATO Office of Information and Press. "The Report Of The Committee Of Three On Non-Military Cooperation In NATO, May 1956." http://www.Nato.Int/Docu/ Basictxt/Bt-A3.htm.

NATO Office of Information and Press. "The Future Tasks Of The Alliance - The Harmel Report,December 13-14, 1967." http://www.Nato.Int/Docu/ Basictxt/B671213a.htm.

NATO Office of Information and Press. "Declaration On A Transformed North Atlantic Alliance Issued By The Heads Of State And Government Participating In The Meeting Of The North Atlantic Council, July 6, 1990." http://www.Nato.Int/ Docu/Basictxt/B900706a.htm.

NATO Office of Information and Press. "The Alliance's Security Concept Agreed by the Heads of State and Governments Participating in the Meeting of the North Atlantic Council, November 8, 1991," http://www.nato.int/docu/basictxt/ b911108a.htm.

NATO Office of Information and Press, "The Alliance's Strategic Concept Agreed By The Heads Of State And Government Participating In The Meeting Of The North Atlantic Council, November 8, 1991." http://www.Nato.Int/Docu/ Basictxt/B911108a.htm. 
NATO Office of Information and Press. "Communiqué Issued By The Ministerial Meeting Of The North Atlantic Council, December 17, 1992."

http://www.nato.int/docu/comm/49-95/c921217a.htm.

NATO Office of Information and Press. "Study on NATO Enlargement, September 1995." http://www.nato.int/docu/basictxt/enl-9501.htm.

NATO Office of Information and Press. "Collective Security and the Post-Cold War World: Speech by Secretary Solana at the Conference on Crisis Management and NATO Reform, June 1998." http://www.nato.int/docu/speech/1998/ s980615a.htm.

NATO Office of Information and Press. "NATO: Its 50th Anniversary -The

Washington Summit - The Next Century, January 25, 1999." http://www.Nato.Int/Docu/Speech/1999/S990125a.htm.

NATO Office of Information and Press. "Washington Summit Communique: An Alliance for the $21^{\text {st }}$ Century, April 24, 1999." http://www.nato.int/docu/pr/ 1999/p99-064e.htm.

NATO Office of Information and Press. "NATO Handbook, 2001." http://www.nato.int/docu/handbook/2001/.

NATO Office of Information and Press. "Statement by the Secretary General of NATO, September 11, 2001." http://www.nato.int/docu/pr/2001/p01-121e.htm.

NATO Office of Information and Press. "Press Availability: U.S. Deputy Secretary of State Armitage and NATO Secretary General Lord Robertson, September 20, 2001." http://www.nato.int/docu/speech/2001/s010920a.htm.

NATO Office of Information and Press. "Statement by Lord Robertson, October 2, 2001." http://www.nato.int/docu/speech/2001/s01 1002a.htm.

NATO Office of Information and Press. "NATO Naval Force Deploys to Eastern Mediterranean, October 9, 2001." http://www.nato.int/docu/update/2001/1008/ e1009a.htm.

NATO Office of Information and Press. "Statement by the EAPC, September 12, 2001." http://www.nato.int/docu/pr/2001/p01-123e.htm.

NATO Office of Information and Press. "Statement to the Press By NATO Secretary General Lord Robertson of the North Atlantic Council Decision on Implementation of Article 5 of the Washington Treaty Following the 11 September Attacks Against the United States, October 4, 2001.” http://www.nato.int/docu/speech/2001/s011004b.htm. 
NATO Office of Information and Press. "Speech by the Secretary General at the Annual Conference of the Defence and Society, January 21, 2002." http://www.nato.int/docu/speech/2002/s020121a.htm.

NATO Office of Information and Press. "Statement by the Secretary General on the Conclusion of Operation Eagle Assist, April 30, 2002." http://www.nato.int/ docu/update/2002/04-april/e0430a.htm.

NATO Office of Information and Press. "NATO's Military Concept for Defense Against Terrorism, November 21, 2002." http://www.nato.int/ims/ docu/terrorism.htm.

NATO Office of Information and Press. "Summit Declaration on Iraq, November 21, 2002." http://www.nati.int/docu/comm/2002/0211-prague/index.htm.

NATO Office of Information and Press. "Prague Summit Declaration Issued by the Heads of State and Government Participating in the Meeting of the North Atlantic Council in Prague, November 21, 2002." http://www.nato.int/docu/pr/2002/p02127e.htm.

NATO Office of Information and Press. "Statement of the Vilnius Group Countries, February 5, 2003." http://www.nato.int/romania/vilgroupowel.htm.

NATO Office of Information and Press. "Statement by the Secretary General on the North Atlantic Council Meeting, February 6, 2003." http://www.nato.int/ docu/speech/2003/s030206a.htm.

NATO Office of Information and Press. "Video Lecture: NATO-EU Relations. February 12, 2004." http://www.nato.int/docu/speech/2004/s0402 I0a.htm.

NATO Office of Information and Press. "How Did NATO Survive The Cold War?" NATO Video Lecture Transcript, March 11, 2004." http://www.Nato.Int/ Multi/Video/Lectures/031104/V031104a1.htm

NATO Office of Information and Press. "NATO Factsheet: NATO in Afghanistan, February 12, 2005." http://www.nato.int/issues/afghanistan/040628-factsheet.htm.

NATO Office of Information and Press. "Address by Secretary General, Jaap de Hoop Scheffer 'Transforming NATO - A Political and Military Challenge, April 14, 2005." http://www.nato.int/docu/speech/2005/s050414a.htm.

NATO Office of Information and Defense. "Speech by H.E. Mr Søren Gade Minister of Defense, Denmark, The Danish Response to the Transformation Challenge, April 14, 2005." http://www.nato.int/docu/speech/2005/s050414c.htm. 
NATO Office of Information and Press. "Remarks by General James L. Jones, Supreme Allied Commander Europe, What has NATO learned from its operations? April 14, 2005. http://www.nato.int/docu/speech/2005/s050414i.htm.

NATO Office of Information and Press. "Address by Nikolay Svinarov, Minister of Defence, Bulgaria Transforming NATO - A Political and Military Challenge? April 14, 2005." http://www.nato.int/docu/speech/2005/s050414g.htm.

NATO Office of Information and Press. "Address by H.E. Mr. Gediminas Kirkilas Minister of National Defence of Lithuania on National Approaches to NATO Transformation at the NATO Annual Conference, April 14, 2005." http://www.nato.int/docu/speech/2005/s050414b.htm.

NATO Office of Information and Press. "NATO Stopwatch: The Transatlantic Link, May 17, 2005." http://www.nato.int/docu/speech/2005/s050517a.htm.

NATO Office of Information and Press. "NATO Update: NATO committed to Iraq, says Secretary General, June 23, 2005." http://www.nato.int/docu/update/ 2005/06-june/e0623a.htm.

NATO Office of Information and Press. "NATO Nations have donated $€ 100$ million worth of equipment to the Iraqi Armed Forces, December 15, 2005." http://www.afsouth.nato.int/JFCN_Missions/NTM-I/Articles/ NTMI_A_14_05.htm.

NATO Office of Information and Press. "Allied Forces Southern Europe, Operation Joint Guardian Overview." http://www.afsouth.nato.int/operations/kfor/ kfor2.htm.

NATO Office of Information and Press. "Statistics: Defense Spending and Military Personnel, Autumn 2005." http://www.nato.int/docu/review/2005/issue3/ english/statistics.html

Norwegian Ministry of Defense. "KFOR 5-Norway's Role as Lead Nation." http://odin.dep.no/fd/engelsk/publ/veiledninger/010011-120019/dok-nn.html.

Public Broadcasting System. “Iraq Aid, October 24, 2003.” http://www.pbs.org /newshour/bb/middle_east/july-dec03/iraq_10-24.html.

Radio Free Europe/Radio Liberty News Line. "European Officials Suggest Stances on Iraq Might Affect Accession, February 10, 2003.” http://www.rferl.org/ newsline/2003/02/100203.asp.

United Nations Documentation Center. "United Nations Security Council Resolution 687, April 3, 1991." http://www.un.org/News/Press/docs/1991/. 
United Nations Documentation Center. "United Nations Security Council Resolution 816, March 31, 1993.” http://daccessdds.un.org/doc/UNDOC/GEN/N93/ 187/17/IMG/N9318717.pdf?OpenElement.

United Nations Documentation Center. "United Nations Security Council Resolution 1160, March 31, 1998." http://daccessdds.un.org/doc/UNDOC/GEN/N98/ 090/23/PDF/N9809023.pdf?OpenElement.

United Nations Documentation Center. "United Nations Security Council Resolution 1199, September 12, 1998." http://daccessdds.un.org/doc/UNDOC/GEN/N98/090 /2279/96/PDF/N9827996.pdf?OpenElement.

United Nations Documentation Center. "United Nations Security Council Resolution 1203, October 24, 1998." http://daccessdds.un.org/doc/UNDOC/GEN/N98/321/ 21/PDF/N9832121.pdf?OpenElement.

United Nations Documentation Center. "United Nations Security Council Resolution 1214, December 8, 1998." http://www.un.org/News/Press/docs/1999/.

United Nations Documentation Center. "Letter dated 15 December 1998 from the Executive Chairman of the Special Commission established by the SecretaryGeneral pursuant to paragraph 9 (b) (i) of Security Council resolution 687, 1991." http://www.un.org/Depts/unscom/s98-1172.htm

United Nations Documentation Center. "Letter from the Permanent Representative of the UK to the President of the Security Council, 19 December 2001." http://www.un.org/News/Press/docs/2001/sc7248.doc.htm.

United Nations Documentation Center. "United Nations Security Council Resolution 1386, December 20, 2001." http://daccessdds.un.org/doc/UNDOC/GEN/ N01/708/55/PDF/N0170855.pdf?OpenElement.

United Nations Documentation Center. "United Nations Security Council Resolution 1413, May 23, 2002." http://daccessdds.un.org/doc/UNDOC/GEN/ N02/397/33/PDF/N0239733.pdf?OpenElement.

United Nations Documentation Center. "United Nations Security Council Resolution 1546, June 8, 2004." http://daccessdds.un.org/doc/UNDOC/GEN/ N04/381/16/PDF/N0438116.pdf?OpenElement.

United Nations Documentation Center. "United Nations Security Council Resolution 1441,November 8, 2002." http://daccessdds.un.org/doc/UNDOC/GEN/ N02/682/26/PDF/N0268226.pdf?OpenElement. 
United Nations Documentation Center. "An Update on Inspection: Report of the Executive Chairman of UNMOVIC to the United Nations Security Council, January 27, 2003." http://www.un.org/ Depts/unmovic/ recent\%20items.html.

United Nations Documentation Center. "United Nations Security Council Resolution 1510, October 13, 2003." http://daccessdds.un.org/doc/UNDOC/GEN/ N03/555/55/PDF/N0355555.pdf?OpenElement.

University of Virginia Library. "The Writings of Thomas Jefferson, Volume 2." http://etext.lib.virginia.edu/etcbin/toccernew2?id=JefBv022.sgm\&images=images $/$ modeng $\&$ data $=/$ texts/english/modeng $/$ parsed $\&$ tag $=$ public $\&$ part $=1 \&$ division $=$ div $1 \%$.

U.S. Central Command. "International Contributions to the War on Terrorism." http://www.centcom.mil/Operations/Coalition/joint.htm.

U.S. Department of Defense. "Transcript: Cohen and Shelton News Conference at NATO Ministers' Conference, September 22, 1999." http://www.usembassyisrael.org.il/publish/press/defence/archive/1999/september/dd1927.htm.

U.S. Department of Defense. "Honorable Walter B. Slocombe, Under Secretary Of Defense For Policy Remarks To The Atlantic Council On European Security Washington, D.C. June 14, 1996." http://www.Dod.Mil/Releases/ 1996/B062096_Bt371-96.html.

U.S. Department of Defense. "Secretary Rumsfeld Briefs at the Foreign Press Center, January 22, 2003." http://www.defenselink.mil/news/Jan2003/ t01232003_t0122sdfpc.html.

U.S. Department of Defense. "Secretary Rumsfeld Media Availability En Route to Poland, September 22, 2002." http://www.defense.gov/transcripts/ 2002/t09232002_t0922sd.html.

U.S. Department of State. "Secretary Powell Remarks to United Nations Security Council, February 5, 2003." http://www.state.gov/secretary/former/ powell/remarks/2003/17300.htm.

U.S. Department of State, "Press Briefing on the President's trip to Europe, May 28, 2002, http://www.state.gov/secretary/rm/2002/10516.htm.

U.S. Department of State. "Operation Enduring Freedom Overview: Campaign Against Terrorism Results, Period Covered 14-30 September 2001.” http://www.state.gov $/ \mathrm{s} / \mathrm{ct} /$ index.cfm?docid=5194. 
U.S. House of Representatives. "Vice Admiral Daniel Murphy Testimony to the House Armed Services Committee, Military Readiness Subcommittee, October 26, 1999." http://www.house.gov/hasc/testimony/106thcongress/99-1026murphy.htm.

U.S. House of Representatives. "Military Readiness Subcommittee Hearing on the Readiness Impact of Operations in Kosovo: Problems Encountered, Lessons Learned, and Reconstitution, October 26, 1999." http://www.house.gov/ hasc/testimony/106thcongress/99-10-26jumper.htm.

U.S. Senate. "Joint Statement to Senate Armed Services Committee by Secretary of Defense William S. Cohen and Gen. Henry H. Shelton on the Kosovo After Action Review, Oct. 14, 1999." http://armed-services.senate.gove/statemnt/ 1999/991014wc.pdf.

U.S. Senate. "Combined Prepared Statement of General Wesley Clark, Admiral Janes Ellis, Jr., and Lieutenant General Michael Short, of the United States European Command Before the Senate Armed Services Committee, October 21, 1999." http://armed-services.senate.gov/statemnt/1999/991021wc.pdf.

U.S. Senate. "United States Senate Committee on Armed Services Testimony on the Lessons Learned from the Military Operations Conducted as Part of Operation Allied Force, and Associated Relief Operations, with Respect to Kosovo. November 3, 1999." http://armed-services.senate.gov/hearings/1999/ c991103.htm.

University of California American Presidency Project. "Address to the Nation Announcing Military Strikes Against Iraq, December 16, 1998." http://ww.presidency.ucsb.edu/ws/print.php?pid=55414.

Western European Union. "Text of The Modified Brussels Treaty." http://www. Weu.Int/Treaty.htm.

Westem European Union. "Petersberg Declaration, June 19, 1992," http://www. weu.int/documents/920619peten.pdf.

White House Office of Press Secretary. "Press Conference By The President With Visegrad Leaders, January 12, 1994.”. http://www.Friends-Partners.Org/ Oldfriends/News/Summit/Visegrad.Pressconf.html.

White House Office of Press Secretary. "Clinton Transmittal To Senate Of Protocols To NATO Treaty, February 11, 1998." http://www.fas.org/man/nato/ offdocs/us_98/98021108_tpo.html. 
White House Office of Press Secretary. "The President in His Address to the Nation, September 11, 2001. http://www.whitehouse.gove/news/releases/2001/ 09/2001/20010911-16.html.

White House Office of Press Secretary. "Joint Address to Congress and the American People, September 20, 2001. http://www.whitehouse.gove/news/releases/2001/ 09/2001/20010920-8.html.

White House Office of Press Secretary. "Remarks by the President and NATO Secretary General Lord Robertson in Photo Opportunity, October 10, 2001." http://www.whitehouse.gov/news/releases/2001/10/20011010-6.html.

White House Office of Press Secretary. "Press Briefing by National Security Advisor Condoleezza Rice, November 8, 2001." http://www.whitehouse.gov/ news/releases/2001/11/20011108-4.html.

White House Office of Press Secretary. "Press Briefing by Ari Fleischer, January 28, 2002." http://www.whitehouse.gov/news/releases/2002/01/20020128-11.html.

White House Office of Press Secretary, "President Delivers State of the Union Address," January 29, 2002. http://www.whitehouse.gov/news/releases/ 2002/01/20020129-11.html.

White House Office of Press Secretary. "President Delivers Graduation Speech at West Point," June 1, 2002. http://www.whitehouse.gov/news/releases/ 2002/06/20020601-3.html.

White House Office of Press Secretary. "Remarks by the President in Address to the United Nations General Assembly, September 12, 2002." http://www.whitehouse. gov/news/releases/2002/09/20020912-1.html.

White House Office of Press Secretary. "Operation Enduring Freedom: One Year of Accomplishments, October 7, 2002." http://www.whitehouse.gov/ infocus/defense/enduringfreedom.html.

White House Office of Press Secretary. "Fact Sheet, "NATO: Building New Capabilities for New Challenges, November 21, 2002." http://www. whitehouse.gov/news/releases/2002/1 1/20021121-6.html.

White House Office of Press Secretary. "President Bush, Prime Minister Blair Hold Press Availability, March 27, 2003." http://www.whitehouse.gov/news/ releases/2003/03/20030327-3.html. 
White House Office of Press Secretary. "President Bush Announces Major Combat Operations in Iraq Have Ended, May 1, 2003." http://www.whitehouse.gov/ news/releases/2003/05/iraq/20030501-15.html.

White House Office of Press Secretary. "Remarks by the Vice President to the Heritage Foundation, October 10, 2003." http://www.whitehouse.gov/news/releases/ 2003/10/20031010-1.html.

Yale University Libraries. "Farewell Address Of 1796." http://www.Yale.Edu/ Lawweb/Avalon/Washing.htm. 
May 24, 1966

1988

1989-Present

1993

2001

2001-2003

2003
Born, Pueblo, Colorado

B.S., Aerospace Engineering

University of Colorado

Boulder, Colorado

Commissioned Officer, United States Air Force

M.S., Systems Management

Air Force Institute of Technology

Dayton, Ohio

M.A. Military Operational Art and Science Air Command and Staff College Montgomery, Alabama

Instructor, National Security Studies Air Command and Staff College Montgomery, Alabama

M.A., International Relations

Auburn University

Montgomery, Alabama 